UNIVERSIDADE DE SÃO PAULO

FACULDADE DE FILOSOFIA, CIÊNCIAS E LETRAS DE RIBEIRÃO PRETO PROGRAMA DE PÓS-GRADUAÇÃO EM EDUCAÇÃO

FERNANDA MARTINS PEREIRA

O PESO DO CAPITAL CULTURAL NOS RESULTADOS DO ENEM-2015 EM RIBEIRÃO PRETO E O CONTRASSENSO DE SEU USO COMO INDICADOR DE QUALIDADE DAS ESCOLAS 
UNIVERSIDADE DE SÃO PAULO

FACULDADE DE FILOSOFIA, CIÊNCIAS E LETRAS DE RIBEIRÃO PRETO PROGRAMA DE PÓS-GRADUAÇÃO EM EDUCAÇÃO

Fernanda Martins Pereira

\title{
O PESO DO CAPITAL CULTURAL NOS RESULTADOS DO ENEM-2015 EM RIBEIRÃO PRETO E O CONTRASSENSO DE SEU USO COMO INDICADOR DE QUALIDADE DAS ESCOLAS
}

\author{
Versão corrigida
}

Dissertação apresentada à Faculdade de Filosofia, Ciências e Letras de Ribeirão Preto da Universidade de São Paulo, como parte das exigências para obtenção do título de Mestra em Educação, obtido no Programa de PósGraduação em Educação

Orientador: Professor Doutor José Marcelino de Rezende Pinto 
AUTORIZO A REPRODUÇÃO E DIVULGAÇÃO TOTAL OU PARCIAL DESTE TRABALHO, POR QUALQUER MEIO CONVENCIONAL OU ELETRÔNICO, PARA FINS DE ESTUDO E PESQUISA, DESDE QUE CITADA A FONTE.

Pereira, Fernanda Martins

O peso do capital cultural nos resultados do ENEM-2015 em Ribeirão Preto e o contrassenso de seu uso como indicador de qualidade das escolas, 2019.

138 p. : il. ; $30 \mathrm{~cm}$

Dissertação de Mestrado, apresentada ao programa de mestrado em educação da Faculdade de Filosofia Ciências e Letras de Ribeirão Preto da Universidade de São Paulo/USP. Área de concentração: Educação.

Orientador: Pinto, José Marcelino R.

1. ENEM. 2. Avaliação. 3. Desempenho. 4. Qualidade. 5. Rankings. 


\title{
TERMO DE APROVAÇÃO
}

\author{
FERNANDA MARTINS PEREIRA
}

\section{O PESO DO CAPITAL CULTURAL NOS RESULTADOS DO ENEM-2015 EM RIBEIRÃO PRETO E O CONTRASSENSO DE SEU USO COMO INDICADOR DE QUALIDADE DAS ESCOLAS}

Dissertação apresentada como requisito parcial para a obtenção do grau de Mestre no Programa de Pós-Graduação em Educação da Faculdade de Filosofia, Ciências e Letras de Ribeirão Preto.

Aprovado em: 11/06/2019

\section{Banca Examinadora}

Teise de Oliveira Guaranha Garcia - USP

Julgamento: aprovada

Ana Lorena Bruel - UFPR

Julgamento: aprovada

Ana Paula Leivar Brancaleoni - UNESP

Julgamento: aprovada 
À minha linda filha Ana Liz, ao advento do Autismo em nossas vidas. 


\section{AGRADECIMENTOS}

Gratidão, reverência e amor a minha família que há três anos nos dá morada e nos sustenta junto às trincheiras diversas. Agradeço à Abigail, minha mãe; à Janaína, minha irmã; Tiago, meu sobrinho. E, sobretudo, agradeço a minha Ana Liz, que restituiu laços e sonhos em nossas vidas. Você é o meu farol.

A meu orientador, José Marcelino, pela grandeza intelectual e polidez. Pelas lições, pela paciência, pelos socorros quase paternais e generosidade. Agradeço por sua atuação emblemática no campo educacional que inspira coragem para resistir aos tempos atuais, diante de um país destroçado pela desesperança e a derrocada democrática.

À CAPES (Coordenação de Aperfeiçoamento de Pessoal de Nível Superior), pelo financiamento ao longo do Mestrado. Seu auxílio, para além de apoio à pesquisa, foi garantia de sobrevivência.

Agradeço a banca examinadora, pela gentileza e disponibilidade em avaliar este trabalho.

Agradeço a Hyago Souza pelo auxílio prestado no manejo dos dados analisados neste estudo.

A todos os trabalhadores da Escola Alayde Figueiredo Palma Canassa de Altinópolis, que em 2018 trouxeram à minha vida satisfação e incentivo, fazendo-me descobrir durante o exercício de meu ofício de professora que o meu lugar de luta na defesa do direito à educação de qualidade é dentro de uma sala de aula da escola pública, no Ensino Fundamental.

Obrigada, Patrícia Almeida, por me ensinar a encarar com leveza as dificuldades cotidianas impostas pelo TEA e ressignificar para mim o sentido da amizade. Pela parceria no ativismo e na luta pelos direitos da pessoa com autismo ao longo das muitas pelejas junto às instâncias jurídicas e poder público de Altinópolis, sempre em favor do cumprimento dos direitos no âmbito da inclusão escolar.

Gratidão a Eduardo Oliveira, por toda sua ajuda, força e alegria representadas em nossos encontros na USP ao longo das muitas disciplinas que cursamos juntos. Considero-te um presente da vida e um perfeito exemplo de determinação.

Por fim, a todos que seguiram ao meu lado durante este período, pela compreensão e apoio diante das circunstâncias que se opuseram à conclusão desta etapa. 


\section{RESUMO}

Considerando os múltiplos fatores que incidem na composição dos resultados de desempenho dos jovens concluintes do Ensino Médio das redes públicas e privada no ENEM 2015 na cidade de Ribeirão Preto, objetiva-se analisar os determinantes circunstanciais relativos ao background familiar e sua confluência no desempenho no exame, discutindo sobre o uso de seus resultados. Para tanto, procede-se à análise descritiva dos dados oficiais e revisão da literatura sobre a história da avaliação externa, aferição da qualidade por testes padronizados e pesquisas de levantamento, sendo possível traçar um esboço temporal do Sistema de Avaliação da Educação Básica (SAEB), a trajetória, configurações e as finalidades do ENEM, e discorrer sobre os desafios e descaminhos do Ensino Médio brasileiro. Observa-se a partir das diferenças entre os públicos das redes pública e privada, conhecidas através do estudo das variáveis (contidas nos Microdados do ENEM 2015 e disponibilizados pelo INEP) a necessidade de examinar com mais profundidade o desempenho das escolas de Ensino Médio acrescentando análises sobre os aspectos históricos da avaliação externa no Brasil e no mundo, das mudanças do ENEM, e sobre o caráter dual do Ensino Médio, o que permite concluir que o ENEM não pode ser tratado como um descritor da qualidade do ensino a considerar prioritariamente o seu caráter seletivo e a questionável legitimação dos rankings pela sociedade.

Palavras-chave: ENEM. Avaliação. Desempenho. Qualidade. Rankings. 


\begin{abstract}
Considering the multiple factors that affect the composition of the performance results of young high school graduates from public and private schools in ENEM 2015 in the city of Ribeirão Preto, the objective is to analyze the circumstantial determinants related to family background and their confluence in exam performance, discussing about the use of their results. To this end, we proceed to the descriptive analysis of official data and literature review on the history of external evaluation, quality measurement by standardized tests and surveys, and it is possible to draw a temporal outline of the Basic Education Assessment System (SAEB). , the trajectory, configurations and purposes of ENEM, and discuss the challenges and mishaps in Brazilian high school. It is observed from the differences between public and private publics, known through the study of the variables (contained in the ENEM Microdata 2015 and provided by INEP) the need to further examine the performance of high schools by adding analyzes on the historical aspects of external evaluation in Brazil and around the world, on the changes in ENEM, and on the dual character of high school, which allows us to conclude that ENEM cannot be treated as a descriptor of the quality of education to consider its priority selective character and the questionable legitimation of rankings by society.
\end{abstract}

Keywords: ENEM. Evaluation. Performance. Quality. Rankings. 


\section{LISTA DE ILUSTRAÇÕES}

QUADRO 1 - AVALIAÇÕES PADRONIZADAS NO BRASIL

GRÁFICO 1 - PERCENTUAL DE PARTICIPANTES DO ENEM 2015 EM RIBEIRÃO PRETO POR GÊNERO DECLARADO.

GRÁFICO 2 - PERCENTUAL (\%) DE PARTICIPANTES POR RENDA MENSAL FAMILIAR, SEGUNDO DEPENDÊNCIA ADMINISTRATIVA.

GRÁFICO 3 - PERCENTUAL DE PARTICIPANTES DO ENEM 2015 EM RIBEIRÃO PRETO QUE DECLARARAM PRESENÇA/FREQUÊNCIA DE EMPREGADA(O) DOMÉSTICA(O) EM RESIDÊNCIA, SEGUNDO DEPENDÊNCIA ADMINISTRATIVA

GRÁFICO 4 - PERCENTUAL DE PARTICIPANTES NO ENEM 2015 EM RIBEIRÃO PRETO QUE POSSUEM ACESSO À INTERNET, SEGUNDO A DEPENDÊNCIA ADMINISTRATIVA.

GRÁFICO 5 - PROFICIÊNCIA MÉDIA POR FAIXA DE IDADE DOS PARTICIPANTES DO ENEM 2015 EM RIBEIRÃO PRETO.

GRÁFICO 6 - PERCENTUAL (\%) DE PARTICIPANTES POR RENDA MENSAL FAMILIAR, SEGUNDO FAIXA DE PROFICIÊNCIA MÉDIA.

GRÁFICO 7 - PERCENTUAL DE PARTICIPANTES DO ENEM 2015 EM RIBEIRÃO PRETO QUE DECLARARAM PRESENÇA/FREQUÊNCIA DE EMPREGADA DOMÉSTICA EM RESIDÊNCIA, SEGUNDO FAIXA DE PROFICIÊNCIA

IMAGEM 1 - PÁTIO INTERNO DA ESCOLA ESPAÇO CULTURAL 100

IMAGEM 2 - FUNDOS DA ESCOLA ESTADUAL EXPEDICIONÁRIOS BRASILEIROS.

IMAGEM 3 - MAPA DO PERCURSO DA UNIDADE LAFAIETE À UNIDADE ALVARES CABRAL.

IMAGEM 4 - ESCOLA CASTELO - FACHADA

IMAGEM 5 - ESCOLA ESTADUAL GUIMARÃES JÚNIOR 114 


\section{LISTA DE TABELAS}

TABELA 1 - MÉDIA DE IDADE DOS PARTICIPANTES DO ENEM 2015 EM RIBEIRÃO PRETO POR DEPENDÊNCIA ADMINISTRATIVA

TABELA 2 - PERCENTUAL DE PARTICIPANTES DO ENEM 2015 EM RIBEIRÃO PRETO POR DEPENDÊNCIA ADMINISTRATIVA, SEGUNDO GÊNERO

DECLARADO.

TABELA 3 - QUANTIDADE E PERCENTUAL DE PARTICIPANTES DO ENEM 2015 EM RIBEIRÃO PRETO POR DEPENDÊNCIA ADMINISTRATIVA, SEGUNDO RAÇA/COR DECLARADA.

TABELA 4 - PERCENTUAL DE PARTICIPANTES NO ENEM 2015 EM RIBEIRÃO PRETO POR ESCOLARIDADE DA MÃE, SEGUNDO DEPENDÊNCIA ADMINISTRATIVA.

TABELA 5 - PERCENTUAL DE PARTICIPANTES DO ENEM 2015 EM RIBEIRÃO PRETO POR DEPENDÊNCIA ADMINISTRATIVA, SEGUNDO A OCUPAÇÃO DA MÃE

TABELA 6 - PERCENTUAL DE PARTICIPANTES DO ENEM 2015 EM RIBEIRÃO PRETO POR DEPENDÊNCIA ADMINISTRATIVA, SEGUNDO A OCUPAÇÃO DO PAI.

TABELA 7 - PERCENTUAL DE PARTICIPANTES DO ENEM 2015 EM RIBEIRÃO PRETO POR NÚMERO DE PESSOAS RESIDENTES, SEGUNDO DEPENDÊNCIA ADMINISTRATIVA.

TABELA 8 - PERCENTUAL DE PARTICIPANTES DO ENEM 2015 EM RIBEIRÃO PRETO POR SUA EXPERÊNCIA LABORAL, SEGUNDO A DEPENDÊNCIA ADMINISTRATIVA

TABELA 9 - PERCENTUAL DE PARTICIPANTES DO ENEM 2015 EM RIBEIRÃO PRETO POR IDADE DE INÍCIO DE ATIVIDADE REMUNERADA, SEGUNDO A DEPENDÊNCIA ADMINISTRATIVA.

TABELA 10 - MOTIVOS QUE LEVARAM À PARTICIPAÇÃO NO ENEM 2015 EM RIBEIRÃO PRETO POR ORDEM DE IMPORTÂNCIA.

TABELA 11 - PERCENTUAL DE PARTICIPANTES DO ENEM 2015 EM RIBEIRÃO PRETO POR SITUAÇÃO DE PERMANÊNCIA NA ESCOLA DURANTE O ENSINO MÉDIO, SEGUNDO A DEPENDÊNCIA ADMINISTRATIVA.....81 
TABELA 12 - QUANTIDADE E PERCENTUAL DE PARTICIPANTES DO ENEM 2015 EM RIBEIRÃO PRETO POR GÊNERO DECLARADO, SEGUNDO FAIXA DE PROFICIÊNCIA MÉDIA.

TABELA 13 - QUANTIDADE E PERCENTUAL DE PARTICIPANTES NO ENEM 2015 EM RIBEIRÃO PRETO POR RAÇA/COR DECLARADA, SEGUNDO FAIXA DE PROFICIÊNCIA MÉDIA.

TABELA 14 - PERCENTUAL DE PARTICIPANTES DO ENEM 2015 EM RIBEIRÃO PRETO POR FAIXA DE PROFICIÊNCIA MÉDIA, SEGUNDO A ESCOLARIDADE DA MÃE.

TABELA 15 - PERCENTUAL DE PARTICIPANTES POR OCUPAÇÃO DA MÃE, SEGUNDO FAIXA DE PROFICIÊNCIA MÉDIA.

TABELA 16 - PERCENTUAL DE PARTICIPANTES POR OCUPAÇÃO DO PAI, SEGUNDO FAIXA DE PROFICIÊNCIA MÉDIA.

TABELA 17 - PERCENTUAL DE PARTICIPANTES DO ENEM 2015 EM RIBEIRÃO PRETO E SUA EXPERÊNCIA LABORAL, SEGUNDO FAIXA DE PROFICIÊNCIA.

TABELA 18 - PERCENTUAL DE PARTICIPANTES DO ENEM 2015 EM RIBEIRÃO PRETO POR TIPO DE INSTITUIÇÃO ESCOLAR FREQUENTADA NO ENSINO MÉDIO, SEGUNDO FAIXA DE PROFICIÊNCIA MÉDIA.

TABELA 19 - PERCENTUAL DE ALUNOS CONCLUINTES DO EM QUE PARTICIPARAM DO ENEM 2015 EM RIBEIRÃO PRETO POR DEPENDÊNCIA ADMINISTRATIVA

TABELA 20 - ESCOLAS DE RIBEIRÃO PRETO POR DEPENDÊNCIA ADMINISTRATIVA E PERCENTUAL DE PARTICIPANTES NEGROS NO ENEM 2015.

TABELA 21 - PERCENTUAL DE MÃES DE ALUNOS PARTICIPANTES DO ENEM 2015 QUE CONCLUÍRAM A EDUCAÇÃO SUPERIOR POR DEPENDÊNCIA ADMINISTRATIVA.

TABELA 22 - MÉDIA GERAL DE DESEMPENHO POR ESCOLA, CONSIDERANDO No DE PARTICIPANTES NO ENEM 2015, PARTICIPAÇÃO DE NEGROS, MÃES COM EDUCAÇÃO SUPERIOR, RENDA, EXERCÍCIO DE ATIVIDADE REMUNERADA E BOLSISTAS NA REDE PRIVADA (PARTE 1: MÉDIA ACIMA DE 550).

TABELA 23 - MÉDIA GERAL DE DESEMPENHO POR ESCOLA, CONSIDERANDO O NÚMERO DE PARTICIPANTES NO ENEM 2015, PARTICIPAÇÃO DE NEGROS, MÃES COM EDUCAÇÃO SUPERIOR, RENDA, EXERCÍCIO DE ATIVIDADE REMUNERADA E PERCENTUAL DE BOLSISTAS NA REDE PRIVADA (PARTE 2: MÉDIA ABAIXO DE 550). 


\section{SUMÁRIO}

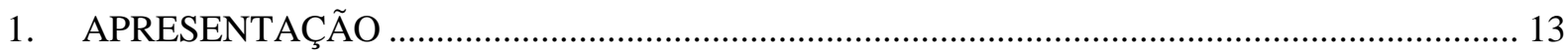

2. AVALIAÇÃO EM LARGA ESCALA E MENSURAÇÃO DA QUALIDADE: NATUREZA E HISTÓRIA NOS ENQUADRAMENTOS INTERNACIONAL E NACIONAL ................................. 20

2.1 AVALIAÇÕES EM LARGA ESCALA: UMA VISÃO GERAL …................................... 26

2.1.1 O papel do SAEB enquanto política de avaliação em larga escala no Brasil................. 31

2.1.2 O papel das avaliações em larga escala nas políticas de equidade e as tensões que

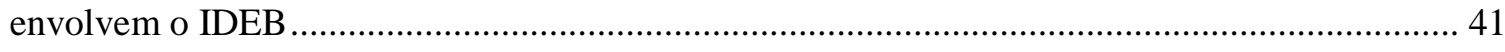

3 O ENEM NO CONTEXTO DAS POLÍTICAS PARA O ENSINO MÉDIO NO BRASIL .......... 45

3.1 ENSINO MÉDIO NO BRASIL: UMA DUALIDADE NÃO RESOLVIDA ....................... 45

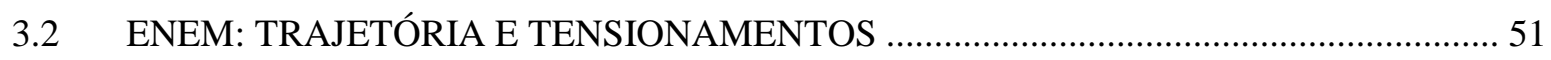

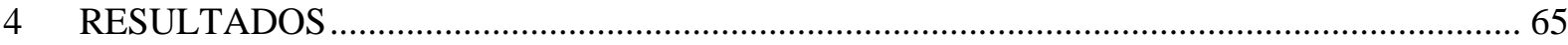

4.1 OS PERFIS DOS PARTICIPANTES DO ENEM 2015 EM RIBEIRÃO PRETO A PARTIR

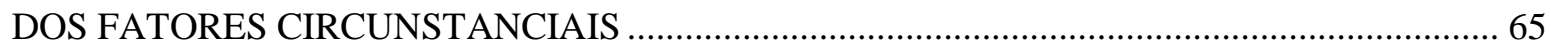

4.2 CARACTERÍSTICAS DE DESEMPENHO E INTERAÇÕES COM O CONTEXTO DOS PARTICIPANTES DO ENEM 2015 EM RIBEIRÃO PRETO..................................................... 81

4.3 RESULTADOS DO ENEM 2015 POR ESCOLA - RIBEIRÃO PRETO............................. 96

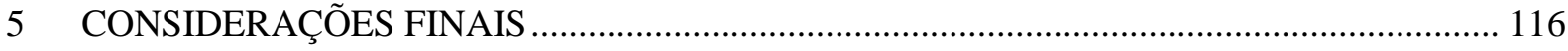

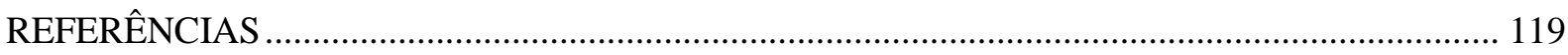

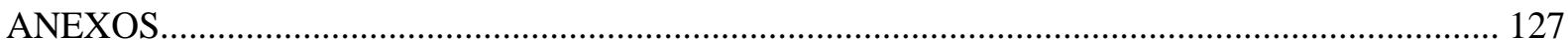




\section{APRESENTAÇÃO}

A avaliação educacional é considerada um campo em disputa de múltiplos enfoques e tem ganhado evidência ao longo das últimas décadas, marcadas pelos desdobramentos das reformas educacionais, e, a esta dinâmica deve-se o novo panorama conceitual sobre uma de suas premissas: mensurar a qualidade na educação a fim de subsidiar políticas de melhoria.

A partir dos anos 90 a avaliação da educação no Brasil ganha expressiva importância no contexto das reformas empresariais que apostam na educação como via de inserção competitiva no mercado internacional, no entanto, a expansão da oferta educacional e idealização da “escola para todos” como meio de justiça social implica reconsiderar a desigualdade entre classes sociais como decretória do fracasso escolar.

Em meio às políticas de democratização do acesso à escola e da obrigatoriedade da Educação Básica ${ }^{1}$, as desigualdades de oportunidades escolares evidentes entre os distintos estratos sociais rompem com o senso comum da visão sobre a ampliação da escolarização como mecanismo de democratização de oportunidades sociais e econômicas.

No cenário que precede a construção do cunho regulatório do Estado, o Exame Nacional do Ensino Médio estabelece o objetivo de conferir ao aluno concluinte da educação básica preceitos de aptidão que lhes garantam entrada no mercado de trabalho e acesso à educação superior. Desta forma, o processo avaliativo do ENEM, enquanto política de avaliação que propõe avaliar em larga escala, tem provocado questionamentos quanto à prevalência de sua natureza seletiva e de processo de verificação de resultado/medição de êxito sobre o seu caráter de avaliação externa da qualidade da educação. Por isso,

Reconhecer a centralidade da avaliação externa no texto e no contexto das atuais políticas educacionais exige tomada de posição que ultrapasse a mera denúncia de equívocos. O que está em jogo é a qualidade na e da escola pública e as inegáveis repercussões para aqueles (não poucos) que dela dependem e aos quais se deve assegurar o direito de acesso, permanência e aprendizagens detentoras de qualidade social (MENDES; CARAMELO; ARELARO; TERRASÊCA; SORDI; KRUPPA, 2015, p. 1288).

\footnotetext{
${ }^{1}$ A Emenda Constitucional 59/2009 altera o art. 208, I da CF/88 a fim de ampliar a obrigatoriedade escolar, estabelecendo como obrigatória a faixa etária de 04 aos 17 anos de idade, implementada em 2016.
} 
Assim, em relação ao caráter regulador do exame, é possível revelar e ampliar compreensão acerca dos mecanismos de escalonamento e diferenciação de prestígio e eficácia entre as escolas públicas e privadas participantes do ENEM, que muitas vezes têm como centro o mérito, encobrindo fatores de contexto que interferem decisivamente no desempenho e trajetória escolar.

O discurso sobre a qualidade presente no cerne das reformas empresariais é obediente ao modelo de gestão da iniciativa privada que tem por base o controle, a responsabilização, metas submetidas à avaliação e a divulgação de resultados. Sob este prisma, faz-se necessário complexificar a análise da história e das mudanças no ENEM, seus objetivos e funções, e situá-lo na macropolítica educacional, compreendendo em profundidade o que realmente desnudam os seus resultados.

Casassus (2007) ressalta que o conceito de qualidade em educação é ambíguo, tautológico e circular, e para o autor, a qualidade tornou-se um conceito central e estratégico nas formulações de política educacional na maioria dos países. A este consenso se deve a necessidade de mensurar a qualidade, antes medida através do acúmulo de anos de escolaridade. Assim nascem hipóteses sobre os fatores contextuais que permeiam o desempenho dentro e fora da escola, mas o foco foi finalmente fixado na medição do sucesso acadêmico, tendo como indicador o desempenho em testes padronizados.

Os sistemas de ensino não apenas reforçam as desigualdades sociais como eles mesmos produzem desigualdades com características propriamente escolares. Cabe frisar que o Ensino Médio brasileiro é marcado por desvios e equívocos que lhe conferem a herança da dualidade estrutural. Deste modo, a avaliação externa no Brasil, a exemplo de toda a história da educação, "responde” prontamente aos parâmetros de distinção social através de processos de seleção que estão por trás da aferição da qualidade.

Logo, na mão dupla da desigualdade a escola acolhe demandas populares, mas nem sempre possui as condições necessárias para atendê-las em sua diversidade, o que pode produzir novas formas de exclusão transmutando desigualdades sociais em desigualdades escolares refletidas no desempenho, cabendo sublinhar que a qualidade no ensino e as políticas de equidade contribuem para que o mínimo necessário à manutenção do percurso escolar de cada aluno atue como fator moderador das desigualdades sociais e também nas desigualdades de desempenho, o que supõem democratizar não apenas o acesso como também equilibrar oportunidades entre ricos e pobres.

Como já dito, grande parte das desigualdades educacionais é produto das diferenças nos níveis socioeconômicos das famílias, aliadas ou não às desigualdades herdadas do 
contexto familiar dos alunos, o que nos obriga a redimensionar os debates em educação, distanciando-nos cada vez mais do ideário que desresponsabiliza a escola diante do papel reprodutor da desigualdade social.

Ademais, para ampliar a compreensão das desigualdades que precedem o desempenho e reconsiderá-lo através das circunstâncias, reitera-se a necessidade de conhecer os perfis dos alunos que chegam até as escolas para então discutir sobre o papel da escola de qualidade, seus limites e suas chances de realizar a tarefa de proporcionar aos estudantes condições para que alcancem desempenho aceitável, mesmo sofrendo influência de fatores extraescolares como a origem e as desigualdades sociais.

Dessa forma, recorreu-se às pesquisas em educação de corte sociológico que emergem após o Relatório Coleman ${ }^{2}$ que tomam o meio familiar e as características de origem, em particular em sua dimensão sociocultural, como um poderoso fator explicativo das desigualdades de oportunidades escolares entre os educandos.

É oportuno frisar que os sistemas de avaliação foram implementados em contextos sociais muito variados, entretanto, são obedientes a uma única lógica de estandardização que aponta suposta elevação de índices de qualidade e são fortemente comprometidos com formação para o mercado de trabalho, como é o caso do ENEM, que se distancia da apreciação da qualidade do Ensino Médio nacional e se retém ao caráter seletivo.

Deste modo, exames estandardizados foram empreendidos como via de padronização da cultura escolar e dos processos pedagógicos convenientes à produção de resultados que levam ao imaginário da sociedade a ideia de que médias mais altas significam melhor qualidade da educação (RAVITCH, 2011).

Dada a importância dos dados de avaliações para constatação das condições de oferta de ensino de qualidade e o cumprimento do direito à educação, entende-se a necessidade de analisar o perfil socioeconômico dos alunos da rede pública e privada e a forma como os dados de desempenho são coletados.

Para isso, foi realizada revisão da bibliografia sobre a história da avaliação em larga escala e a análise de seus efeitos desde o pioneiro Relatório Coleman (1966) que discutiu os determinantes do sucesso nas trajetórias escolares e de vida e sobre supostos indicadores de qualidade através de surveys educacionais que mostravam a influência e relação entre a origem social do aluno e seu desempenho escolar.

\footnotetext{
${ }^{2}$ Relatório Coleman, 1966. Estudo realizado por James S. Coleman que procura explicitar o debate sobre o papel da escola na construção de uma sociedade mais igualitária e procurava estabelecer relações entre as características das escolas e o resultado do desempenho de diferentes grupos de alunos.
} 
De acordo com Nogueira,

De um modo geral, tais pesquisas se atinham, sobretudo às características morfológicas do grupo familiar, expressas através de variáveis como a renda, o nível de instrução e a ocupação dos pais, o número de filhos, o lugar da criança na fratria, etc. Seus resultados indicavam que as vantagens econômicas tinham sobre o desempenho escolar um efeito menor do que aquele dos fatores socioculturais (NOGUEIRA, 2005, p. 564).

Assim sendo, a questão que mobiliza este trabalho é buscar entender o que há por trás do desempenho constatado em testes padronizados, tomando, em particular, os resultados do ENEM 2015 para os estudantes das escolas de Ribeirão Preto. Pretendeu-se discutir acerca da hierarquização dos resultados em virtude do backgroud familiar dos estudantes e de características de origem (cor, raça, renda, gênero).

Para tanto, foi preciso transpor barreiras teóricas do campo conceitual do desempenho escolar (que correspondem fortemente ao discurso do mérito individual), ainda que o resultado se encontre no centro do paradigma avaliativo; e também as barreiras práticas, pois é necessário mensurar e principalmente esclarecer de que forma foram produzidos os dados e resultados de desempenho a partir de fatores de origem social e institucional dos estudantes, considerando-se que para esta análise é também necessário traçar um panorama do perfil do público participante do ENEM, suas expectativas e interações com as mudanças do exame ao longo de história.

Nesse sentido, procurou-se analisar os resultados das escolas de Ribeirão Preto considerando a dependência administrativa como determinante e indicador do desempenho, e, principalmente, de que forma a escola se comporta diante da demanda que recebe. Ressalta-se por isso, a importância de complexificar a análise do desempenho dos estudantes no ENEM, considerando a estrutura multifatorial de sua composição pautada na análise das características individuais de origem, contextuais e familiares reveladas pelos perfis dos estudantes submetidos ao exame.

Diante disso, fez-se necessário reforçar que as características de origem e socioeconômicas representam determinantes relevantes no arranjo multifatorial dos resultados do ENEM 2015 em Ribeirão Preto. A partir das diferenças entre seus públicos, pôde-se examinar com mais profundidade os dados de desempenho dos alunos matriculados nas escolas das redes pública e privada.

Para compreender a relação dos resultados do ENEM com as desigualdades educacionais e sociais foi necessário recuperar suas finalidades e responsabilidades na 
distribuição de oportunidades e o contexto histórico-político do Ensino Médio assim como o do Sistema de Avaliação da Educação Básica.

Após traçado o percurso histórico das avaliações em larga escala no mundo e no Brasil e aprofundados pontos importantes sobre o surgimento, mudanças, aspectos técnicos e o atual caráter do ENEM, foram analisados os dados oficias de desempenho da edição de 2015 do Exame Nacional do Ensino Médio em Ribeirão Preto e analisadas as informações coletadas nos questionários socioeconômicos respondidos pelos inscritos.

Procurou-se também, diante das informações de contexto coletadas, questionar se o exame pode ou não respaldar a discussão sobre políticas educacionais de qualidade e equidade na Educação Básica, respectivamente a partir da legitimação dos rankings pela sociedade e dos programas governamentais de acesso à universidade.

Destacados os fatores que abarcam as circunstâncias de origem sintetizadas por variáveis relativas ao background familiar do participante do ENEM 2015, tornou-se eminente um perfil de aluno pregresso tanto da rede estadual quanto da rede privada de Ribeirão Preto, o que fez possível refletir sobre a força do fator socioeconômico perante o efeito escola.

Assim, reitera-se o objetivo do presente estudo de analisar os fatores associados ao desempenho no ENEM dos estudantes das redes públicas e privadas de Ribeirão Preto, em 2015, buscando conjugar na análise os dados de contexto dos estudantes com as características das escolas participantes, além de compreender, diante desta análise, se esta conjuntura possibilita que o ENEM seja uma via justa de ampliação da democratização do acesso ao Ensino Superior, bem como um descritor da qualidade das escolas.

Com base nesse objetivo geral, seguem como objetivos específicos: a) apurar o percentual de participação das escolas no ENEM 2015 de acordo com as variáveis renda, raça/cor, gênero declarado e dependência administrativa; b) esboçar o perfil dos alunos inscritos no exame nas redes de ensino pública/estadual e privada; c) promover o levantamento das médias de proficiência por escola; d) traçar diferenças de desempenho a partir da média e variação dos resultados de acordo com o tipo de escola e circunstâncias socioeconômicas; e) discutir sobre como o ENEM favorece o mito da qualidade que está por trás da hierarquização e rankeamento dos resultados divulgados.

Os dados de contexto familiar dos inscritos foram obtidos a partir das respostas aos questionários de auto declaração contidos nos microdadados do ENEM 2015. Assim, foram consideradas as variáveis que partem das características individuais, familiares e socioeconômicas dos participantes pretendendo-se assim, estudar a hierarquização dos 
resultados em virtude dos perfis levantados pelos Microdados do ENEM 2015, alinhando os resultados aos perfis socioeconômicos dos estudantes e às suas características de origem como raça, gênero, renda e estilos de vida.

As informações presentes no questionário socioeconômico (microdados do ENEM) sobre trajetórias e circunstâncias de vida dos sujeitos avaliados foram tomadas como possíveis fatores relacionados ao desempenho. A análise considerou os seguintes aspectos: 1 . características individuais dos estudantes (gênero, idade, cor); 2. características familiares e de condições de vida (tais como: renda familiar, escolaridade da mãe, ocupação dos pais e exercício de atividade remunerada.); e 3. características das trajetórias escolares (dependência administrativa, tipo de escola de origem, permanência), além dos dados de proficiência.

Sabendo que escolas que oferecem condições adequadas aos critérios de qualidade são então escolas produtoras de outputs favoráveis, é imprescindível conhecer as escolas participantes do ENEM 2015 em que estavam matriculados na cidade de Ribeirão Preto no ano de 2015 para levantamento de fatores intraescolares que incidem nas proficiências, contudo, não foi possível analisar as condições de oferta dessas escolas a partir dos dados pesquisados.

Na metodologia, para a pesquisa quali-quantitativa, recorreu-se à análise descritiva dos dados do INEP sendo previamente realizado levantamento bibliográfico de artigos na plataforma Scielo e Banco de Teses Capes tendo como delimitação temporal de 1990 a 2017, e revisão da literatura referente à temática da avaliação da qualidade educacional e à história do ENEM.

Foi empreendida verificação quantitativa após pesquisa documental dos dados disponibilizados nos Microdados do ENEM para o ano de 2015.

As informações reunidas para traçar os perfis dos participantes da edição do ENEM de 2015 contidas no Microdados do ENEM, disponíveis no Portal do INEP, advém de questionário respondido pelos próprios inscritos no exame. Para análise das respostas numéricas e alfabéticas de autopreenchimento fez-se necessário recorrer ao Dicionário das variáveis explicativas dos Microdados do ENEM e inputs de leitura e programação estatística para o formato SAS.

Para a análise das proficiências dos participantes que foram disponibilizadas pelos Microdados 2015, foram adotadas faixas médias de desempenho (nota máxima possível no exame = 100): a) menor que 450 pontos; b) de 450 a 550; b) de 550 a 650; c) de 650 a 750, e d) mais que 750 pontos). Optou-se por descartar as informações de desempenho dos alunos “eliminados” do exame por ausência em um dos dias de aplicação de prova ou que obtiveram 
nota zero na redação. O trabalho estatístico de organização da base de dados do ENEM 2015 de Ribeirão Preto e de construção das tabelas de referência foi feito pelo estatístico Hyago Souza, a partir de plano tabular estabelecido pela pesquisadora em conjunto com seu orientador.

Nos capítulos adiante estruturados, procurou-se primeiramente, redesenhar o percurso histórico da avaliação em larga escala percorrendo a produção bibliográfica sobre o tema, em uma perspectiva crítica tendo como ponto de partida a publicação da do Relatório Coleman, (COLEMAN, 1966). Foram apresentados estudos sobre os sistemas de avaliação no Brasil, seu papel nas políticas de equidade e de qualidade, e discutidos de maneira sucinta os efeitos da criação e implantação do IDEB.

Posto isto, mais especificamente, no segundo capítulo é feita a discussão das avaliações em larga escala e de seu papel na discussão sobre a qualidade do ensino no contexto internacional e no Brasil.

O capítulo três busca descrever e discutir o papel do ENEM no contexto e estrutura do Ensino Médio no Brasil através do percurso das políticas de educação até os dias atuais. Foi realizada a descrição do ENEM de alguns aspectos técnicos, legislação, reconfigurações e as tensões atuais relativas à sua finalidade.

No capítulo quatro, foram apresentados os resultados. Foi realizado o levantamento do perfil dos alunos participantes do ENEM 2015 das redes de ensino de Ribeirão Preto e o estudo de seus desempenhos para subsidiar a discussão sobre as diferenças entres os públicos das redes pública e privada e a formação dos rankings.

Finalmente, no capítulo 5 são feitas as considerações finais do trabalho. 


\section{AVALIAÇÃO EM LARGA ESCALA E MENSURAÇÃO DA QUALIDADE: NATUREZA E HISTÓRIA NOS ENQUADRAMENTOS INTERNACIONAL E NACIONAL}

Para ampliarmos a compreensão sobre a avaliação da qualidade e sua relevância diante das políticas educacionais é necessário recorrermos aos objetivos desta avaliação e considerarmos todos os âmbitos que permeiam esse processo. Dada a importância que existe em constatar a qualidade do ensino através de dados de desempenho, cabe ressaltar, que avaliar é investigar a realidade preambular dos resultados. Para tanto, é importante delinear adequadamente a que se deve essa investigação.

A avaliação de acordo com Lima (2008, p. 8) está condicionada à concepção de sociedade e de educação, “[...] um caminho que deve ser construído pelos sujeitos a partir das relações interpessoais estabelecidas na coletividade”. No entanto, a avaliação, diante das reformas educacionais neoliberais, tem como função, nas perspectivas técnico-burocrática e participativa, organizar as suas políticas de distribuição de recursos e melhorar a qualidade prestando conta à sociedade (DIAS SOBRINHO, 2003).

Na década de 80, no quadro internacional, inteiramente quantitativo, a qualidade da educação era legitimada pelo acúmulo de anos de escolaridade que uma pessoa possuía, ou pela taxa de matrícula que um país apresentava (CASASSUS, 2007). Contudo, em nome da competitividade surge a necessidade da medição e para isso foi preciso novo foco para uma apreciação qualitativa que pudesse diferenciar os resultados: o capital humano.

Para Casassus (2007, p. 45), “qualidade da educação pode ser entendida como um nível aceitável de rendimento ou sucesso acadêmico”, e assim definida, embora de maneira restrita, segundo o autor, tem o mérito de identificar uma variável, a nota, que pode ser associada com um conjunto de fatores explicativos.

Segundo Franco e Bonamino (1999), os primeiros estudos sobre avaliação da qualidade a partir de dados de desempenho eram pautados prioritariamente nos determinantes extraescolares socioeconômicos e familiares, e a partir da década de 1980, aparecem tanto os estudos e pesquisas que enfatizam os fatores intraescolares, como os que procuram equacionar conjuntamente os fatores sociais e escolares nas desigualdades educacionais e diferentes desempenho.

Para Franco et al (2007), o conceito de equidade intraescolar não deve ser considerado de modo independente do conceito de eficácia. Assim, para os autores, um conjunto de boas práticas escolares atua no sentido de aumentar o desempenho médio das 
escolas, o que pode atuar como fator moderador das desigualdades sociais, pois ações voltadas a um ensino de qualidade podem contribuir para a consolidação de práticas educativas mais equitativas. Ou seja, o ensino de qualidade atenua as distâncias já impostas pela falta de oportunidades decorrentes da origem social.

Uma política avaliativa orientada pela equidade deve considerar que seus resultados são claramente hierarquizados por estratos sociais. As políticas educacionais neoliberais acatam o princípio de igualdade de direito, que pode vir a acontecer em relação ao acesso à escola, mas não acontece no âmbito dos resultados e o critério de desigualdade calcado no sucesso individual que é imperativo da diferenciação na seleção econômica e social (CASASSUS, 2007).

Nesse sentido, a avaliação da qualidade resguardada pelo peso das circunstâncias confere importância ao encaminhamento de políticas educacionais pautadas pela equidade onde o direito à educação ocupa lugar elementar e o ensino se dá de forma responsiva às necessidades sociais de cada educando.

Pesquisas diversas revelam que o fracasso escolar é mais presente entre as populações mais pobres, e para entender mais claramente os fatores que afetam o desempenho é impreterível que sejam considerados fatores familiares, de origem e contexto intraescolar na análise de variância.

Ball (2002) adverte que, nossas relações sociais tornam-se relações de julgamento a partir das pressões das avaliações, e a educação que busca por resultados ou por desempenho não reconhece que tão importante quanto os resultados são os caminhos que levam a ele, ou seja, os fatores situacionais que desenham as trajetórias escolares.

A partir disso, é necessário, portanto rever a falsa ideia de que o desempenho é sinônimo, ou consequência direta, de mérito e esforço individual em detrimento dos fatores que permeiam sua produção como as características de origem ligadas à desigualdade social e fatores de qualidade que consolidam o percurso de insucesso.

Ademais, a pesquisa de Buchmann e Hannum (2001) examina a desigualdade educacional a partir da relação entre contexto familiar e resultados educacionais, dos efeitos dos fatores intrínsecos escolares, e do impacto da educação sobre mobilidade econômica e social. Para as autoras, as diferenças de desempenho estão evidentes na relação entre fatores de oferta, ou seja, as oportunidades e recursos educacionais disponíveis, que abarcam a qualidade do ensino e demais determinantes intraescolares associados aos fatores de demanda, correspondem aos processos ligados às origens socioeconômicas e familiares. 
É desta forma, correto admitir que as diferenças na oferta e qualidade do ensino possuem importante papel na perpetuação da circularidade entre as desigualdades sociais e desigualdades educacionais, e abarcam múltiplos fatores que impedem a superação da distribuição desigual de oportunidades através da ação da escola, que poderia e deveria atenuar déficits provenientes da origem social dos alunos.

Diante disso, sabe-se que as variáveis intraescolares e os processos que se desenvolvem dentro da escola conferem peso consubstancial na garantia do direito à educação de qualidade e que as características de origem representam determinantes de grande importância no arranjo multifatorial que resulta no desempenho do aluno.

Assim, de acordo com Freitas,

Se isso é verdadeiro, as políticas de equidade devem ser associadas às políticas de redução e eliminação das desigualdades sociais, fora da escola. Isso implica continuar a produzir a crítica do sistema social que cerca a escola, além de introduzir a importância do nível socioeconômico como variável relevante nas análises de avaliação do desempenho do aluno e da escola (FREITAS, 2007, p. 971).

Como foi dito, pesquisas em educação de corte sociológico emergem após o Relatório Coleman de 1966, que será analisado adiante através de seus impactos nas políticas liberais de investimento em educação ${ }^{3}$, e tomam o meio familiar e as características de origem, em particular em sua dimensão sociocultural, um poderoso fator explicativo das desigualdades de oportunidades escolares entre os educandos (NOGUEIRA, 2005).

Todavia, cabe lembrar que apesar de existir uma vasta produção científica, é presente uma gama de posições, por vezes controversas, voltadas ao estudo do impacto das variáveis de contexto escolar nos indicadores de desempenho produzidos em avaliações de larga escala e sobre a hierarquia resultante dessas variáveis.

Para tanto, é preciso ressignificar a leitura dos dados de desempenho, pois, para além de mensurar é preciso esclarecer de que forma são produzidos os dados e resultados de desempenho e clarear a noção de qualidade da educação que vem sendo difundida através das avaliações padronizadas. Conforme afirmam Sousa e Oliveira:

Embora se reconheçam tais limitações, o dimensionamento da qualidade de ensino tem sido apresentado como carro-chefe de várias iniciativas de avaliação de sistema que se apoiam sobremaneira no desempenho dos alunos, quer censitariamente, quer por procedimentos de amostragem da população referida. Por sua vez, não excluindo essa primeira perspectiva, argumenta-se que essas práticas avaliativas seriam indutoras de níveis crescentes de qualidade de ensino. Esses pontos de partida

\footnotetext{
${ }^{3}$ Coleman questiona a eficácia do investimento público na criação de igualdade de oportunidades escolares respaldado pela teoria do capital social.
} 
revelam-se, no entanto, extremamente controvertidos pelas dificuldades de definir a qualidade de ensino de forma operacional, inclusive por conta de seus condicionantes sociais e históricos [...] (SOUSA; OLIVEIRA, 2010, p. 799).

Os estudos transversais desenvolvidos nas avaliações em larga escala retém as variáveis a um único momento de medição, o que imprime certo risco em designar atributos e valores às características que se pretende relacionar às medidas de qualidade.

Deste modo, é importante questionar se os testes padronizados de larga escala contribuem ou não para a orientação de políticas de qualidade, e discutir a repercussão de exames estandardizados em relação à significação da qualidade na educação, de forma a evitar tendências contemporâneas que se conformam ao fato de que a qualidade que vem sendo forjada e tem-se restringido à apreciação de resultados de proficiência, sem que estes sejam interpretados à luz de condições contextuais, intra e extraescolares (SOUSA, 2014).

Sobre a intenção dos sistemas de avaliação, sabe-se, segundo Franco, Brooke e Alves, que

\footnotetext{
$\mathrm{O}$ interesse dos pesquisadores e gestores de sistemas educacionais consiste em conhecer o efeito de políticas e práticas educacionais sobre o aprendizado dos alunos. No entanto, as mencionadas experiências de avaliação da educação não oferecem os dados mais adequados para inferências causais acerca de quais políticas e práticas fazem diferença em educação. Em outras palavras, enquanto uma sequência de resultados do SAEB oferece boa orientação sobre a tendência da qualidade da educação nacional, ela não oferece a possibilidade de estudo pormenorizado sobre quais fatores promovem ou conspiram contra a qualidade (FRANCO; BROOKE; ALVES, 2008, p. 627).
}

Ademais, a avaliação da qualidade na educação por meio de testes padronizados corre o risco de reconhecer como mérito o que na verdade seria resultado de circunstâncias extra e intraescolares, encobrindo fatores que implicam na baixa qualidade do ensino e não somente no baixo desempenho, ou seja, é fundamental a análise concomitante das características individuais dos alunos, de suas condições de vida, das características da escola a que tiveram acesso, considerando que as condições de qualidade da oferta educacional podem ser ocultadas pelo resultado em avaliações padronizadas.

Tal risco pode desqualificar a interpretação e o uso dos resultados de proficiência como uma proxy da qualidade de ensino, por isso é preciso que sejam tomados os devidos cuidados para analisar os múltiplos aspectos da realidade educacional. Da análise dos indicadores, para além da hierarquização, emergem necessidades de mudanças estruturais, da valorização dos profissionais da educação, gestão democrática e justa distribuição de recursos.

Sobre isso, Sousa acrescenta: 
Portanto, a avaliação educacional mantem intrínseca relação com uma dada concepção de qualidade da educação. Seja qual for o objeto de avaliação - alunos, currículo, profissionais, instituições, planos, políticas, entre outros - o delineamento adotado em sua implantação e o uso que se fizer de seus resultados expressam o projeto educacional e social que se tem por norte (SOUSA, 2014, p. 408).

Dada a importância dos dados de avaliações sistêmicas e externas para constatação da oferta de ensino de qualidade, entende-se a necessidade de analisar o contexto e a maneira como os dados de desempenho são coletados.

As avaliações em larga escala podem ser amostrais, ou censitárias. O modelo amostral é aplicável a apenas um percentual de alunos assegurando sua representatividade estatística em relação ao todo, com a finalidade de validar dados de resultados que espelhem a realidade de um grande grupo de alunos, permitindo uma análise muito abrangente que não vislumbra o tratamento pormenorizado dos dados. A avaliação de caráter censitário também permite o estudo amplo de dados de desempenho, e identifica perfis e grupos de sujeitos envolvidos nos processos escolares. Assim, a

\footnotetext{
Abrangência, metodologia e comparabilidade permitem de forma sistêmica compreender que a avaliação externa constitui um instrumento importante de coleta de informações sobre determinado universo permitindo classificação e identificação dos dados investigados através de indicadores de desempenho (RISCAL e LUIZ, 2016, p. 64).
}

A produção de indicadores de desempenho através das avaliações em larga escala possibilita que sejam direcionadas, reformuladas e adequadas políticas educacionais vigentes a partir de dados coletados em um só momento de aferição, arriscando classificar a qualidade como um subproduto das políticas em educação, sem que sejam consideradas as condições oferecidas para a produção de resultados, podendo, assim, mascarar a desigualdade de oportunidades de sucesso escolar.

No cenário tomado por influências reformistas da década de 1990 que privilegiam a aferição de resultados de desempenho como forma de atestar a qualidade do ensino, a avaliação assume-se também como mecanismo de pressão e controle, e é modelada como via de padronização da cultura escolar e dos processos pedagógicos, reconfigurando o que se compreende como qualidade do ensino a partir da medição.

O caráter gerencial da avaliação externa/em larga escala se torna um importante instrumento dentro da ideia onde a avaliação de desempenho é parte do planejamento estratégico e está fortemente relacionado à gestão de qualidade e à lógica competitiva e classificatória de natureza econômico-financeira, portanto, 
A instalação da nova cultura da performatividade competitiva envolve o uso de uma combinação de devolução, metas e incentivos para se efectuar o replaneamento institucional. Isto advém não só de uma teoria econômica recente como também de várias práticas industriais (BALL, 2002, p. 8).

E ainda, reforçado por Freitas,

O conceito de avaliação que emergiu privilegiou a avaliação externa em todos os níveis de ensino, sob a lógica da competitividade entre as organizações ou entre os professores, em que a qualidade era produto da própria competição e não uma construção coletiva, a partir de indicadores legitimados socialmente pelos atores (FREITAS, 2004, p. 149).

Ainda sobre os fins e meios da avaliação externa, os países que adotam este modelo, salvaguardando o objetivo de dar suporte, monitoramento e aprimoramento das políticas educacionais públicas, em geral, optam pela avaliação amostral. Já aqueles que possuem como foco o caráter fiscalizador e de responsabilização, optam pela avaliação censitária.

No cenário internacional pós Segunda Guerra Mundial, na Europa são propostas iniciativas que busquem construir indicadores que estabeleçam padrões de desenvolvimento econômico e social através acordos de mútuo apoio e integração internacional.

Para Freitas (2005), isto implica em perda de autonomia, soberania e autoridade do Estado perante outras nações. Assim, para o autor, além disso, o Estado pode, legitimamente, transferir parte de seus poderes a tais organismos, para além das fronteiras territoriais e os limites de sua atuação reguladora.

Ao passo que a organização escolar atual comprova a forte influência das reformas educacionais internacionais que servem ao ideal do triunfo econômico pela via da educação, reforçadas pela ideia que o ensino tem caráter de manutenção da economia global a partir da formação novos mercados consumidores, é estabelecida franca desregulamentação dos processos públicos que legitimam a eminência de privatização dos processos operacionais que ocorrem dentro da escola.

A reconfiguração do papel do Estado na formulação e implementação de políticas para a educação pública frente às reformas educacionais consiste na subordinação da educação aos imperativos mercantis que denotam cunho empresarial à gestão e práticas educacionais.

Presume-se, dessa maneira, que a ideia de "governança sem governo" é traduzida como parca autoridade governamental diante das premissas internacionais. Freitas (2005) assinala que, embora o Estado permaneça como detentor dos mecanismos que lhe permitem 
assegurar a soberania em seu território, há uma influência crescente das organizações supranacionais e dos compromissos assumidos pelos países que delas participam (RIZCAL; LUIZ, 2016).

Segundo Freitas (2005), é através desse ângulo de vista que se deve analisar o percurso das avaliações em larga escala, a sua finalidade e o uso de seus indicadores de desempenho, compreendendo-os como instrumentos administrativos da educação e de controle.

É importante ressaltar que nessa perspectiva, a pesquisa educacional, a destinação de investimentos em educação e o caráter diagnóstico da avaliação são apresentados como elementos de subsídio para o progresso nacional. Implícito aí se encontra o intuito de imputar à educação finalidades que pertencem à economia, com a premissa de que a ampliação dos resultados em educação e o ideal de qualidade representam o caminho mais viável para alavancar a economia. Logo, as atividades de pesquisa, planejamento e avaliação educacional deveriam se orientar por essa diretriz (FREITAS, 2005).

Traçada a relação entre os porquês da avaliação educacional dentro do ideário reformista e a emergência do aprimoramento do tratamento dos dados de desempenho através do prisma contextual socioeconômico no fim do século XX, o próximo item tem a intenção de traçar o percurso das avaliações externas na perspectiva internacional.

\subsection{AVALIAÇÕES EM LARGA ESCALA: UMA VISÃO GERAL}

Com o objetivo de fomentar o uso de resultados de pesquisas educacionais como ferramentas para o planejamento e gestão, conferências internacionais foram realizadas nas décadas de 1950 e 1960 para estimular o intercâmbio e cooperação entre os países quanto à criação de unidades de informação pedagógica no sentido de unificar objetivos (FREITAS, 2005).

Em geral, foram recomendadas a garantia de recursos apropriados e a avaliação dos processos e resultados para aferição da qualidade da educação oferecida. Desta forma, caberia ao Estado, entre outros setores da sociedade, um papel gerencial fiscalizador (FREITAS, 2005).

Entre as conclusões da First International Conference On Educational Research, realizada em fevereiro de 1956 em Atlantic City, nos Estados Unidos, levantava-se a viabilidade e credibilidade técnica de uma pesquisa internacional, através da qual os resultados fossem comparáveis entre países de diferentes patamares socioeconômicos e que, 
ainda assim, pudesse produzir diagnósticos de ordem local. A solução desse desafio possuía desse modo, um caráter contrário ao intuito de estabelecer qualquer programa internacional de cooperação em pesquisa educacional, apresentando, claramente, uma vertente padronizada de avaliação e de qualidade (RISCAL; LUIZ, 2016).

Nesse processo, cabe destacar alguns dos marcos do percurso histórico da pesquisa educacional e políticas de avaliação pelo mundo, e mencionar o surgimento de importantes organizações como a UNESCO, que em 1958 reuniu na Alemanha intelectuais pesquisadores que discutiam os objetivos da avaliação da aprendizagem e problemas de rendimento escolar.

Desse trabalho, surgiu a International Association for the Evaluation of Educational Achievement (IEA), sediada em Amsterdã, Holanda, tendo como projeto inaugural o Pilot Twelve-Country Study, que, de acordo Riscal e Luiz (2016), fora constituído para

\begin{abstract}
[...] estudar a viabilidade da inclusão de métodos empíricos entre os instrumentos de investigação da pesquisa educacional e da pesquisa de educação comparada, bem como determinar os desafios de se estender a abrangência desse tipo de trabalho a diferentes sistemas de ensino. O estudo tinha por objetivo, também, a identificação de padrões intelectuais referentes a certas disciplinas básicas do currículo escolar sob diferentes condições. [...] a pesquisa englobou conhecimentos de matemática, compreensão de leitura, geografia, ciências e habilidades não verbais e deu à IEA a experiência necessária para a elaboração de outros estudos pontuais em larga escala ao longo da década de 1960. Posteriormente, a partir da década de 1970, o foco da IEA deslocou-se para as avaliações periódicas, cujo principal objetivo seria possibilitar aos países participantes uma comparação longitudinal do progresso de seus sistemas educacionais (UNESCO, 1962 apud RISCAL; LUIZ, 2016, p. 66).
\end{abstract}

Na análise da evolução das avaliações de larga escola no mundo, não se pode deixar de mencionar o icônico Relatório Coleman, desenvolvido na década de 1960. O estudo Equality of Education Opportunity (Coleman, 1966) foi considerado um dos estudos mais importantes da área educacional realizados no século XX (RISCAL; LUIZ, 2016). Tratava-se de uma pesquisa quantitativa para desvendar a desigualdade de oportunidades educacionais na escola pública do EUA, sobretudo disparidades educacionais presentes em determinados grupos étnicos.

Coleman buscou compreender a maneira como as escolas públicas americanas ofereciam igualdade de oportunidades educacionais e se a ofereciam de fato, a partir de critérios que pudessem ser considerados como indicadores de qualidade educacional. Esses indicadores tanto poderiam ser tangíveis (por exemplo, a quantidade de livros nas bibliotecas) como intangíveis, como o conteúdo curricular ou as habilidades, formação e nível cultural dos professores (RISCAL; LUIZ, 2016). 
A principal conclusão do estudo de Coleman (1966) foi a de que o nível socioeconômico dos alunos e sua base de conhecimento prévio eram os fatores mais significativos na determinação dos seus resultados educacionais, enquanto as diferenças na qualidade de escolas e professores possuíam impacto comparativamente menor, embora também significantes (COLEMAN, 1966 apud RISCAL; LUIZ, 2016).

De acordo com Coelho (2008, apud Riscal e Luiz, 2016), os resultados do Relatório Coleman, colocaram em cheque a efetividade da escola como meio de promover a igualdade de oportunidades em grupos com características socioeconômicas tão distintas, e através da superação de problemas de aprendizagem oriundos das desigualdades sociais e de oportunidades. Esses estudos questionam de maneira incisiva o ponto de vista liberal quanto à função social da escolarização, assumindo tendências simpatizantes das teorias de reprodução social e cultural, onde educação escolar no contexto capitalista legitima a estrutura social dominante.

A partir daí, foi criado um movimento de pesquisa sobre a eficácia escolar com foco na análise dos fatores que incidem no sucesso e fracasso escolar. Surgem diversos modelos analíticos e técnicas para o levantamento de informações. Segundo a análise de Coleman, “Tudo pareceria indicar que o investimento público em busca de uma melhora da qualidade educativa estaria fadado ao fracasso" (SALEJ, 2005, p. 126).

Após o Relatório Coleman, o governo americano inaugurou um sistema de avaliação em larga escala da educação, o National Assessment of Educational Progress (NAEP), iniciado em 1969 e que ainda se mantem em atividade até os dias de hoje (RISCAL; LUIZ, 2016). Seus indicadores foram elaborados para garantir a comparabilidade entre os resultados dos testes ao longo das décadas e o NAEP utiliza, assim como o ENEM, para análise do desempenho, a TRI (Teoria da Resposta ao Item), que será detalhada mais adiante, na descrição analítica do ENEM.

Em 1960, na Europa, surge a Organisation for Economic Co-operationand Development (OECD), fundada em Paris. De acordo com Riscal e Luiz (2016), consta em sua página oficial, que o trabalho da OECD baseia-se na monitorização contínua de eventos em países, membros, ou não, e inclui projeções regulares da evolução econômica de curto e médio prazo. Assim, para os autores, é evidente o discurso pautado na intervenção, monitoramento, controle e gerenciamento materializado por meio de avaliações, e de forte caráter econômico.

Para Araújo (2013, apud Riscal e Luiz, 2016, p. 70), “a característica principal da Organização é a formulação de estratégias e coordenação de posições dentro do seu raio de 
ação e atuar como 'tribunal’ das políticas dos países-membros, intercâmbio e manancial de informações”.

Nessa direção, cabe salientar o papel central do Banco Mundial como grande financiador de projetos que promovessem ou mensurassem os retornos de seus investimentos globais nas grandes estruturas financeiras a fim de se certificar sobre a formação de indivíduos adequados ao modelo social subserviente ao consumo.

Na década de 1990 as políticas públicas educacionais sofreram grande influência da globalização dos interesses mercantis. Neste âmbito, para Freitas (2004, p.146), "Estados como o Brasil, sob o efeito das mudanças nas relações internacionais (a chamada globalização) foram colocados na contingência de induzir soluções preconcebidas alémfronteira em seus assuntos locais”, o que elege um só parâmetro de testagem de qualidade na educação para múltiplas realidades econômicas.

De uma forma geral, o caráter central das reformas empresariais e tendências à privatização é a difusão de supostas soluções dos problemas de gestão educacional a partir do aumento de produtividade e desempenho escolar (atestados pelo rendimento em avaliações externas) transmutando a realidade e contexto escolar em estandartes da gestão empresarial da qualidade.

Assim, o novo paradigma avaliativo moldado em uma lógica mercadológica reconfigura simultaneamente o papel do Estado frente à obrigatoriedade da oferta de ensino de qualidade, à visão de aluno, bem como aos próprios objetivos da educação. Terreno fértil para a privatização da Educação Básica, que cada vez mais perde seu caráter institucional e incorpora ideias corporativistas com a interferência de investimentos da iniciativa privada, onde residem os maiores interesses reguladores.

Diante disso, para Salej,

\footnotetext{
Parte-se do axioma de que o Estado não deve subsidiar a oferta educativa e sim sua demanda. Em termos práticos, a melhora da qualidade e a universalização do serviço educativo seriam atingidas via crescimento econômico, pois este permitiria melhoras na renda da população, e ao Estado só caberia regular o mercado educativo e alocar bolsas de estudo para a população que não tem renda suficiente (SALEJ, 2005, p. 126).
}

Nesse espectro, em 1997 é criado o PISA, Programa Internacional de Avaliação dos Estudantes, que constitui atualmente a maior avaliação de larga escala em educação no mundo. Em 2012 o exame já contava com a participação de mais de meio milhão de estudantes na faixa etária de 15 anos, em 65 países (OECD, 2014 apud LUIZ; RISCAL 2016). 
Em 2015, 70 países participaram do exame trienal, sendo 35 deles membros da OCDE e 35 países/economias parceiras. Aproximadamente 32 mil alunos brasileiros em 964 escolas participaram da avaliação das áreas de Ciências, Matemática, Leitura, Resolução Colaborativa de Problemas e Competência Financeira (INEP, 2016).

Segundo o Portal do INEP ${ }^{4}$, a ideia do PISA é aferir o conhecimento sobre conceitos, habilidades, motivação e confiança para a aplicação desse conhecimento em tomadas de decisões. Os estudantes são submetidos à avaliação de letramento financeiro, sob a justificativa da necessidade de compreender melhor como os jovens estão sendo formados para lidar com situações que envolvam dinheiro e investimentos, frente a desafios como envelhecimento da população, diminuição em arrecadação ou apoio governamental e mudanças no mercado. A relação entre as medições em larga escala e a economia, segundo Terrasêca (2016), fica bastante nítida nas recentes publicações do Programa PISA, no qual participantes são designados “economias e países”. A essa ideia está imputado o objetivo de que a educação é instrumento que prepara para um mundo competitivo, onde é necessário o domínio de habilidades para atingir pleno potencial para fins de manutenção de postos de trabalho.

No Brasil, o INEP, Instituto Nacional de Estudos e Pesquisas Educacionais Anísio Teixeira, é encarregado de operacionalizar o PISA (RISCAL; LUIZ, 2016). O INEP é uma autarquia federal vinculada ao Ministério da Educação MEC, cuja missão institucional é promover estudos, pesquisas e avaliações sobre a educação brasileira.

"Diferentemente das demais avaliações, o estudo proposto pelo PISA permite ao Brasil aferir conhecimentos e habilidades dos estudantes de 15 anos em leitura, matemática e ciências, contrastando com resultados do desempenho de alunos dos países membros da OCDE, além de 35 países/economias parceiras” (INEP, 2016, p. 18).

Os instrumentos do PISA fornecem indicadores de perfil básico de conhecimento e habilidades dos estudantes; indicadores derivados de questionários que mostram como tais habilidades são relacionadas a variáveis demográficas, sociais, econômicas e educacionais; e indicadores de tendências que acompanham o desempenho dos estudantes e monitoram os sistemas educacionais ao longo do tempo (INEP, 2016).

“O PISA também coleta informações sobre o histórico familiar dos alunos, suas oportunidades e seus ambientes de aprendizagem. Os questionários contextuais gerais dos estudantes e da escola são obrigatórios a todos os países participantes” (INEP, 2016, p. 19).

\footnotetext{
${ }^{4}$ Acessível em: http://portal.inep.gov.br/artigo/-/asset_publisher/B4AQV9zFY7Bv/content/id/1473928. Consulta realizada em 05/01/2019.
} 
No item seguinte será feito um panorama da avaliação em larga escala no Brasil, com foco no SAEB, ficando a discussão do ENEM para o terceiro capítulo.

\title{
2.1.1 O papel do SAEB enquanto política de avaliação em larga escala no Brasil
}

Em 1990, foi criado o SAEB (Sistema de Avaliação da Educação Básica) ${ }^{5}$, gerido pelo INEP, composto por um conjunto de avaliações externas em larga escala. Seu objetivo, segundo publicado no Portal do INEP $^{6}$, era o de realizar um diagnóstico do sistema educacional brasileiro fornecendo um indicativo sobre a qualidade do ensino ofertado.

As informações produzidas deveriam, dessa forma, subsidiar a formulação, melhoria e o monitoramento das políticas educacionais em esfera municipal, estadual e federal, contribuindo para a melhoria da qualidade e garantir a equidade na educação.

De acordo com o INEP (2017), por meio desse sistema, buscava-se identificar a eficiência das redes de escolas brasileiras, valendo-se para isto: da avaliação do desempenho dos alunos em momentos conclusivos das diversas etapas de seu percurso escolar, e ao mesmo passo, da contextualização das condições em que o processo de ensino e aprendizagem ocorria. Segundo o órgão,

\begin{abstract}
Os dados obtidos permitem acompanhar a evolução do desempenho dos alunos e dos diversos fatores e aspectos que estão associados à qualidade e à efetividade do ensino ministrado nas escolas [...]. A partir das informações do SAEB, o Ministério da Educação (MEC) e as Secretarias Estaduais de Educação têm podido definir ações voltadas para a correção dos problemas identificados e dirigir seu apoio técnico e financeiro tanto para o desenvolvimento e aperfeiçoamento das redes de ensino, quanto para a redução das desigualdades ainda existentes no sistema educacional. Além disso, realizar avaliações e divulgar seus resultados é uma forma de o poder público prestar contas da sua atuação à sociedade em geral, proporcionando uma visão clara dos resultados do processo de ensino e das condições em que é desenvolvido (INEP, 2017, p. 3).
\end{abstract}

O INEP atualmente destaca como meta principal o diagnóstico da educação básica no Brasil e de fatores que possam interferir no desempenho do estudante, ao fornecer um indicativo sobre a qualidade. Entre seus objetivos, está o levantamento de dados e a apreensão de fatores que possam ser componentes determinantes do desempenho do estudante como o objetivo de dimensionar a qualidade do ensino ofertado, e em consonância com os objetivos

\footnotetext{
${ }^{5}$ Neste capítulo, o termo SAEB remete ao Sistema de Avaliação que engloba o conjunto de avaliações nacionais a ele incorporadas.

${ }^{6}$ Acessível em: http://portal.inep.gov.br/web/guest/educacao-basica/saeb. Consulta realizada em 21/09/2018.
} 
do SAEB, subsidiar o monitoramento e implementação de políticas públicas para a área educacional a partir de parâmetros de qualidade e equidade ${ }^{7}$.

Como aponta Silva (2010, p. 430), “o Instituto não realiza todo o processo sozinho, pois recebe assessoria de empresa especializada na constituição de base de dados e na produção das escalas de desempenho, que é contratada por meio de licitação internacional”.

Para Franco (2001), o SAEB, além de produzir informações claras e confiáveis aos gestores, pesquisadores, educadores e público em geral, buscava realizar o acompanhamento do sistema educacional e aferição de competências; esse objetivo impõe a necessidade de obtenção de boas medidas de proficiência que sejam comparáveis ao longo dos anos e de adequada interpretação da escala de desempenho.

As tendências internacionais e a incorporação da dinâmica internacional nas primeiras experiências brasileiras na avaliação da educação com a implantação do SAEB fizeram com que a qualidade da educação passasse a ser representada pelos resultados dos alunos nos testes padronizados, em detrimento à análise conjuntural que também considerasse as informações obtidas por meio dos questionários contextuais que possibilitam agregar aos resultados de desempenho novas perspectivas de análise.

Isto posto, o desafio em buscar medidas de desempenho realmente capazes de mensurar a aprendizagem dos alunos residia na superação da tarefa estritamente quantitativa, na investigação dos fatores sobre a qualidade da oferta de ensino e na discussão sobre a distribuição de oportunidades escolares que precediam os resultados das provas.

Brooke e Soares afirmam que

\begin{abstract}
“Após o SAEB, os sistemas educacionais puderam ser analisados não só em relação à sua capacidade de atendimento às crianças em idade escolar, mas também em relação ao aprendizado de seus alunos. Pela primeira vez tornou-se possível avaliar aquelas características das escolas que mais se associavam á aprendizagem. Mediante o cruzamento de informações sobre condições de funcionamento das escolas, as características socioeconômicas dos alunos e o nível de aprendizagem alcançado, a pesquisa brasileira começou a quantificar o efeito-escola e a desvendar as especificidades da escola eficaz” (BROOKE; SOARES, 2008, p. 9).
\end{abstract}

A dimensão "contexto" deve considerar fatores de interferência no desempenho que transcendem os contextos escolares. Segundo o INEP (2018), após discussão com especialistas e debates na DAEB (Diretoria de Avaliação da Educação Básica), a equidade passou a ser considerada como um dos eixos de qualidade da educação e "tem como objetivo

\footnotetext{
${ }^{7}$ Acessível em: http://portal.inep.gov.br/educacao-basica/saeb/historico-do-saeb. Consulta realizada em 21/09/2018.
} 
verificar como se encontra o complexo e persistente quadro de desigualdades e violações de direitos que, de variadas formas, cerceiam o direito à educação de qualidade, especialmente entre grupos historicamente discriminados e/ou sociopoliticamente implicados em processos de vulneração” (INEP, 2018, p. 36).

Como já discutido, estudantes pertencentes a famílias de baixo nível socioeconômico apresentam piores resultados e rendimento escolar quando comparados aos de meios privilegiados, em razão das oportunidades educativas e da estabilidade na vida cotidiana propiciadas pela favorável condição econômica, e das possibilidades prévias de construção de predisposições sociais e culturais, geralmente alinhadas à cultura escolar (INEP, 2018 apud ALBERNAZ, FERREIRA, FRANCO, 2002; ANDRADE, LAROS, 2007; SOARES \& ALVES, 2013).

As médias de desempenho produzidas pelos exames do SAEB são associadas aos dados de aprovação escolar obtidos no Censo Escolar. O IDEB enquanto indicador da qualidade do ensino no país, em uma escala de 1 a 10, é um elemento norteador do Plano Nacional de Educação (PDE). Os resultados desse índice são utilizados pelo Ministério da Educação para estabelecer metas de desenvolvimento da educação.

A primeira aplicação do SAEB, então um só exame, aconteceu em 1990 com a participação amostral (gerando resultados em diferentes escalas para diferentes regiões do país) de escolas públicas urbanas que ofertavam as $1^{\mathrm{a}}, 3^{\mathrm{a}}, 5^{\mathrm{a}}$ e $7^{\mathrm{a}}$ séries do Ensino Fundamental. O exame avaliou a aprendizagem dos alunos em Língua Portuguesa, Matemática e Ciências. As $5^{\mathrm{a}}$ e $7^{\mathrm{a}}$ séries também foram avaliadas em redação e este formato se manteve nos três anos seguintes. A partir de 1995 foi adotada a TRI ${ }^{8}$ (Teoria de Resposta ao Item) como metodologia de construção do teste e análise de resultados, sob a justificativa da necessidade de assegurar, ao longo dos anos, a comparabilidade entre os resultados das avaliações. Neste ano, o público avaliado correspondia às etapas finais dos ciclos de escolarização do Ensino Fundamental e Ensino Médio. Além da amostra da rede pública, em 1995 foi acrescentada uma amostra da rede privada.

É importante lembrar que a partir da edição de 2001, o SAEB passou a avaliar apenas as áreas de Língua Portuguesa e Matemática. Tal formato se manteve nas edições de 2003, 2005, 2007, 2009 e 2011.

\footnotetext{
${ }^{8}$ A TRI é uma nova metodologia de análise do desempenho dos alunos. Segundo consta em justificativa do Projeto Básico do SAEB, ela é necessária porque os métodos estatísticos clássicos permitem apenas o uso de uma única prova, com um número limitado de itens, com prejuízo da cobertura dos tópicos dos programas que os alunos aprendiam. (INEP, 2017).
} 
O INEP afirma que o objetivo da avaliação é auxiliar os governantes nas decisões e no direcionamento de recursos técnicos e financeiros, assim como a comunidade escolar, no estabelecimento de metas e na implantação de ações pedagógicas e administrativas, visando melhorar a qualidade do ensino ${ }^{9}$.

Em 2005 o SAEB foi reestruturado pela Portaria Ministerial nº 931, de 21 de março de 2005 alterando significativamente o modelo de avaliação da educação escolar desenvolvido em seu primeiro ciclo de 1990, tornando-o mais abrangente. O SAEB se divide em duas avaliações: Avaliação Nacional da Educação Básica (Aneb) e Avaliação Nacional do Rendimento Escolar (Anresc), mais comumente conhecida como Prova Brasil.

\begin{abstract}
Na referida portaria, a Aneb e seus objetivos, características e procedimentos, realizados por meio de amostras, foram mantidos. São eles: avaliação da qualidade, equidade e eficiência dos sistemas e redes de ensino brasileiros; avaliação por amostragem em larga escala, por meio de testes de desempenho em Língua Portuguesa - foco em leitura - e Matemática - foco em resolução de problemas; utilização de metodologias formais e científicas para a coleta, sistematização de dados e produção de informações sobre o desempenho dos alunos do ensino fundamental e médio, bem como sobre as condições escolares e extraescolares que incidem sobre o processo ensino-aprendizagem. Dessa forma, a avaliação da qualidade, equidade e eficiência dos sistemas e redes de ensino brasileiros a que se propõe a Aneb é feita por meio destes dois instrumentos: testes de desempenho e questionários. A aplicação dos testes de desempenho na Aneb inclui uma amostra representativa de alunos de 4 a série $/ 5^{\circ}$ ano e 8 a série $/ 9^{\circ}$ ano do ensino fundamental e de 3a série do ensino médio das escolas das redes pública e privada, localizadas nas zonas rural e urbana, distribuídas nas 27 unidades da Federação. Já os questionários são aplicados para estudantes, docentes e gestores escolares. (INEP, 2018, p. 09).
\end{abstract}

Essas mudanças, segundo o INEP, foram feitas com o propósito de imprimir um caráter sistêmico à avaliação da educação, considerando a necessidade de adequação às premissas legais, especialmente a Constituição Federal, a Lei de Diretrizes e Bases da Educação Nacional e o Plano Nacional de Educação, foi crucial realizar um estudo sobre o arcabouço teórico que dá fundamentação ao SAEB (INEP, 2018).

Como resultado, foram definidos eixos de qualidade na Matriz da Avaliação do SAEB em atenção ao seu objetivo cardeal. Para isso, definem-se, a partir do tradicional modelo de fluxo, quais são as funções da educação escolar, a necessidade de ampliar o conceito de qualidade e redimensionar os instrumentos de medida e estudos a partir dos quais seja possível fazer uma análise aprofundada sobre a realidade educacional da Educação Básica no Brasil (INEP, 2018).

\footnotetext{
${ }^{9}$ Acessível em http://portal.inep.gov.br/web/guest/caracteristicas-saeb. Consulta realizada em 04/06/2018.
} 
Com a reestruturação do SAEB, a Anresc (Prova Brasil), segundo o INEP, foi idealizada para atender a demanda dos gestores públicos, educadores, pesquisadores e da sociedade em geral por informações sobre o ensino oferecido e passou a avaliar de forma censitária as escolas que atendessem a critérios de quantidade mínima de estudantes nas séries avaliadas, permitindo gerar resultados por escola ${ }^{10}$. A Anresc é mais extensa e detalhada que a Aneb, tem foco em cada unidade escolar, e por seu caráter universal, recebe o nome de Prova Brasil em suas divulgações.

Na edição de 2005, o público-alvo da Anresc (Prova Brasil) se consolidou nas escolas públicas com no mínimo 30 estudantes matriculados na última etapa dos anos iniciais ( $5^{\circ}$ ano) ou dos anos finais ( $9^{\circ}$ ano) do Ensino Fundamental. A metodologia utilizada nessa avaliação foi similar à utilizada na avaliação amostral, com testes de Língua Portuguesa e Matemática. O foco era leitura e resolução de problemas.

Em 2007 passaram a participar da Anresc (Prova Brasil) as escolas públicas rurais que ofertavam os anos iniciais (até o $5^{\circ}$ ano) do Ensino Fundamental e que tinham um mínimo de 20 estudantes matriculados nessa série. A partir dessa edição, a Anresc (Prova Brasil) passou a ser realizada em conjunto com a aplicação da Aneb, de aplicação amostral do SAEB, utilizando os mesmos instrumentos.

Na edição de 2009, os anos finais (9 $9^{\circ}$ ano) do Ensino Fundamental de escolas públicas rurais também passaram a ser avaliados.

Em 2011, cerca de 55.924 escolas públicas participaram da parte censitária e 3.392 escolas públicas e particulares participaram da parte amostral.

Na edição de 2013 a ANA, prevista no Pacto Nacional pela Alfabetização na Idade Certa - PNAIC, passou a compor o SAEB a partir da divulgação da portaria $\mathrm{n}^{\circ}$ 482, de 7 de junho de 2013. Esta nova avaliação, aplicada anualmente desde 2017 assume caráter censitário e avalia a qualidade do ciclo de alfabetização das redes públicas ${ }^{11}$.

A ANA, que tem como objetivo aferir os níveis de alfabetização e letramento em Língua Portuguesa e Matemática dos estudantes do $3^{\circ}$ ano do Ensino Fundamental das escolas públicas. As provas aplicadas aos alunos forneceram três resultados: desempenho em leitura, desempenho em matemática e desempenho em escrita.

Além dos testes de desempenho aplicados de forma censitária, que medem a proficiência dos estudantes nessas áreas, a ANA apresentou em sua primeira edição, em 2013

\footnotetext{
${ }^{10}$ Acessível em http://portal.inep.gov.br/web/guest/caracteristicas-saeb. Consulta realizada em 25/10/2017.

${ }^{11}$ Acessível em: http://portal.inep.gov.br/web/guest/educacao-basica/saeb/sobre-a-ana. Consulta realizada em 30/08/2018.
} 
(aplicação piloto), ano de sua criação, informações contextuais como o Indicador de Nível Socioeconômico e o Indicador de Formação Docente da escola. A avaliação foi aplicada também em 2014 e 2016, sendo cancelada edição de 2018 sob a justificativa da necessidade de construir uma nova prova a partir da nova Base Nacional Comum Curricular.

Em 2015 foram avaliados além dos alunos do $5^{\circ}$ e $9^{\circ}$ ano do Ensino Fundamental, fizeram a prova estudantes da $3^{\text {a }}$ série do Ensino Médio de escolas públicas e estratos censitários de escolas privadas $^{12}$. A novidade desta edição foi a inclusão da Plataforma Devolutivas Pedagógicas que, de acordo com o INEP, serve de aproximação das avaliações externas de larga escala e o contexto escolar a partir da disponibilização dos itens utilizados na Prova Brasil, descritos e comentados por especialistas.

Em 2017, as escolas públicas do ensino fundamental e as de ensino médio, públicas e privadas, passaram a ter resultados no Sistema de Avaliação e, consequentemente, no Índice de Desenvolvimento da Educação Básica (IDEB), de acordo com a Portaria 564 que determina que o público-alvo do SAEB, passaria a ser: a) todas as escolas públicas, localizadas em zonas urbanas e rurais, que possuam dez ou mais estudantes matriculados em turmas regulares de $3^{\circ}, 5^{\circ}$ e $9^{\circ}$ anos do Ensino Fundamental; b) todas as escolas públicas e privadas, localizadas em zonas urbanas e rurais, que possuam pelo menos dez estudantes matriculados em turmas regulares na $3^{\text {a }}$ série do Ensino Médio ou na $4^{\text {a }}$ série do Ensino Médio, quando esta for a série de conclusão da etapa; c) uma amostra de escolas privadas, localizadas em zonas urbanas e rurais, que possuam estudantes matriculados em turmas regulares de $5^{\circ}$ e $9^{\circ}$ anos do Ensino Fundamental e $3^{\text {a }}$ série do Ensino Médio, distribuídas nas vinte e sete unidades da Federação.

Segundo informações do Portal do MEC, para participar do SAEB, as escolas devem preencher os dados declarados ao censo escolar e precisam ter realizado o preenchimento do Censo da Educação Básica do ano anterior ${ }^{13}$.

As avaliações do SAEB são obrigatórias apenas para as escolas públicas e segundo informações contidas no Portal do MEC, as escolas privadas devem passar por uma segunda etapa, que é a assinatura do termo de adesão, em sistema on-line disponível no portal do INEP, e recolhimento de valor fixado por meio de Guia de Recolhimento da União (GRU). A taxa de adesão para escolas privadas é calculada de acordo com o número de alunos registrado no Censo: entre 10 e 50 alunos matriculados, o valor é de R\$ 400. Entre 51 e 99 alunos, R\$ 2

\footnotetext{
${ }^{12}$ Acessível em http://portal.inep.gov.br/educacao-basica/saeb. Consulta realizada em 30/08/2018.

${ }^{13}$ Acessível em: http://portal.mec.gov.br/component/tags/tag/31992 . Consulta realizada em 15/11/17.
} 
mil. A partir de 100 alunos, R\$ 4 mil. Escolas privadas sorteadas para compor a amostra são isentas do pagamento.

Em 2019, as siglas ANA, Aneb e Anresc deixarão de existir e todas as avaliações passarão a ser identificadas pelo nome SAEB, acompanhado das etapas, áreas de conhecimento e tipos de instrumentos envolvidos. As aplicações se concentrarão nos anos ímpares e a divulgação dos resultados, nos anos pares. Um dos destaques da reestruturação é a afirmação de dimensões da qualidade educacional que extrapolam a aferição de proficiências em testes cognitivos. As condições de acesso e oferta das instituições de Educação Infantil passarão a ser avaliadas. Mesmo com as alterações, o sistema não perderá a comparabilidade entre edições ${ }^{14}$.

A Provinha Brasil é uma avaliação diagnóstica do nível de alfabetização das crianças matriculadas no segundo ano de escolarização das escolas públicas brasileiras. Essa avaliação acontece em duas etapas, uma no início e a outra ao término do ano letivo. A aplicação em períodos distintos possibilita aos professores e gestores educacionais a realização de um diagnóstico mais preciso que permite conhecer o que foi agregado na aprendizagem das crianças, em termos de habilidades de leitura dentro do período avaliado.

Cabe lembrar que a Provinha Brasil não é uma avaliação externa e sim um instrumento que oferece aos professores e gestores escolares um diagnóstico do processo de aprendizagem e níveis de desenvolvimento da alfabetização dos alunos do $2^{\circ}$ ano do Ensino Fundamental. Seus resultados passaram a ser compilados pelos próprios professores. A prova não gera índices que reflitam a situação de todo o sistema de ensino, portanto, não serve para instrumentalizar políticas públicas. Os resultados são de uso interno de cada unidade escolar $^{15}$.

O Quadro 1, a seguir, sintetiza características das avaliações nacionais operacionalizadas pelo INEP: a) exames que compreendem o SAEB; b) a Provinha Brasil ${ }^{16}$, avaliação diagnóstica que visa investigar as habilidades desenvolvidas pelas crianças matriculadas no $2^{\circ}$ ano do ensino fundamental das escolas públicas brasileiras c) o Exame

\footnotetext{
${ }^{14}$ Acessível em: http://portal.inep.gov.br/web/guest/educacao-basica/saeb. Consulta realizada em 28/01/2019.

${ }^{15}$ Acessível em: http://www.todospelaeducacao.org.br/reportagens-tpe/30849/perguntas-e-respostas-o-que-e-aprovinha-brasil/. Consulta realizada em 24/06/2017.

16 A Portaria $n^{\circ}$ 867, de 4 de julho de 2012, instituiu o Pacto Nacional pela Alfabetização na Idade Certa (PNAIC) com a proposta de assegurar que todas as crianças estejam alfabetizadas até os oito anos de idade, ao final do $3^{\circ}$ ano do ensino fundamental, conforme uma das metas previstas pelo Decreto $\mathrm{n}^{\circ}$ 6.094, de 24 de abril de 2007, referente ao Plano de Metas Compromisso Todos pela Educação, utiliza a Provinha Brasil como meio de aferir os resultados.
} 
Nacional do Ensino Médio, que será detalhado no capítulo seguinte, c) do Exame Nacional para Certificação de Competências de Jovens e Adultos (Encceja), realizado pela primeira vez em 2002 para aferir competências, habilidades e saberes de jovens e adultos que não concluíram o Ensino Fundamental ou Ensino Médio na idade adequada, e d) o Programa Internacional de Avaliação de Estudantes (Pisa, do inglês Programme for International Student Assessment).

QUADRO 1 - AVALIAÇÕES PADRONIZADAS NO BRASIL

\begin{tabular}{|c|c|c|c|c|c|}
\hline AVALIAÇÃO & $\begin{array}{c}\text { PÚBLICO } \\
\text { ALVO }\end{array}$ & REGULARIDADE & DIRETRIZ(ES) & RESULTADO & OBJETIVO(S) \\
\hline $\begin{array}{c}\text { Avaliação } \\
\text { Nacional de } \\
\text { Rendimento } \\
\text { Escolar (Anresc } \\
\text { ou Prova Brasil) }\end{array}$ & $\begin{array}{c}5^{\circ} \text { e } 9^{\circ} \text { anos do } \\
\text { EF urbanas e } \\
\text { rurais das redes } \\
\text { públicas }\end{array}$ & A cada dois anos & $\begin{array}{c}\text { Língua } \\
\text { Portuguesa e } \\
\text { Matemática }\end{array}$ & $\begin{array}{l}\text { Por escola, por } \\
\text { rede, por } \\
\text { município, por } \\
\text { unidade da } \\
\text { federação, por } \\
\text { região e para o } \\
\text { Brasil }\end{array}$ & $\begin{array}{c}\text { Avaliar a } \\
\text { qualidade do } \\
\text { ensino das } \\
\text { escolas públicas }\end{array}$ \\
\hline $\begin{array}{c}\text { Avaliação } \\
\text { Nacional da } \\
\text { Educação Básica } \\
\text { (Aneb) }\end{array}$ & $\begin{array}{c}5^{\circ} \text { e } 9^{\circ} \text { anos do } \\
\text { EF e } 3^{a} \text { série do } \\
\text { EM das redes } \\
\text { pública e privada } \\
\text { (escolas que não } \\
\text { atendem aos } \\
\text { requisitos de } \\
\text { participação da } \\
\text { Prova Brasil) }\end{array}$ & A cada dois anos & $\begin{array}{c}\text { Língua } \\
\text { Portuguesa e } \\
\text { Matemática }\end{array}$ & $\begin{array}{l}\text { Por escola, por } \\
\text { unidade da } \\
\text { federação e por } \\
\text { região }\end{array}$ & $\begin{array}{c}\text { Avaliar a } \\
\text { qualidade do } \\
\text { ensino das } \\
\text { escolas, dos } \\
\text { estados e das } \\
\text { regiões do Brasil }\end{array}$ \\
\hline $\begin{array}{c}\text { Avaliação } \\
\text { Nacional de } \\
\text { Alfabetização } \\
\text { (ANA) }\end{array}$ & $\begin{array}{l}3^{\circ} \text { ano do EF das } \\
\text { escolas públicas }\end{array}$ & A cada dois anos & $\begin{array}{c}\text { Língua } \\
\text { Portuguesa e } \\
\text { Matemática }\end{array}$ & $\begin{array}{l}\text { Por escola, por } \\
\text { município e por } \\
\text { unidade da } \\
\text { federação }\end{array}$ & $\begin{array}{c}\text { Aferir os níveis } \\
\text { de alfabetização e } \\
\text { letramento }\end{array}$ \\
\hline $\begin{array}{c}\text { Exame Nacional } \\
\text { do Ensino Médio } \\
\text { (ENEM) }\end{array}$ & $\begin{array}{c}\text { Alunos que } \\
\text { querem ingressar } \\
\text { na Educação } \\
\text { Superior }\end{array}$ & Anual & $\begin{array}{c}\text { Linguagens, } \\
\text { Matemática, } \\
\text { Ciências } \\
\text { Humanas e } \\
\text { Ciências da } \\
\text { Natureza }\end{array}$ & Individual & $\begin{array}{c}\text { Seleção para } \\
\text { ingresso em } \\
\text { universidades } \\
\text { públicas e } \\
\text { concessão de } \\
\text { bolsas em IES } \\
\text { privadas }\end{array}$ \\
\hline AVALIAÇÃO & $\begin{array}{c}\text { PÚBLICO } \\
\text { ALVO }\end{array}$ & REGULARIDADE & DIRETRIZ(ES) & RESULTADO & OBJETIVO(S) \\
\hline
\end{tabular}




\begin{tabular}{|c|c|c|c|c|c|}
\hline Provinha Brasil & $\begin{array}{c}\text { Aluno } \\
\text { matriculado no } 2^{\circ} \\
\text { ano do Ensino } \\
\text { Fundamental }\end{array}$ & $\begin{array}{l}\text { Anual - ao início do } \\
2^{\circ} \text { ano do EF e ao } \\
\text { final desse mesmo } \\
\text { ano letivo }\end{array}$ & $\begin{array}{l}\text { Alfabetização e } \\
\text { letramento na } \\
\text { fase inicial e } \\
\text { Alfabetização da } \\
\text { Matemática } \\
\text { inicial }\end{array}$ & Por turma & $\begin{array}{c}\text { Promover } \\
\text { avaliação } \\
\text { diagnóstica da } \\
\text { alfabetização }\end{array}$ \\
\hline $\begin{array}{c}\text { Exame Nacional } \\
\text { para } \\
\text { Certificação de } \\
\text { Competências de } \\
\text { Jovens e Adultos } \\
\text { (Encceja) }\end{array}$ & $\begin{array}{l}\text { Alunos de pelo } \\
\text { menos } 15 \text { anos } \\
\text { para a } \\
\text { certificação do } \\
\text { EF e alunos de } \\
\text { pelo menos } 18 \\
\text { anos para a } \\
\text { certificação do } \\
\text { EM }\end{array}$ & Anual & $\begin{array}{c}\text { Para o EF: } \\
\text { Língua } \\
\text { Portuguesa, } \\
\text { Língua } \\
\text { Estrangeira } \\
\text { Moderna, Artes, } \\
\text { Educação Física, } \\
\text { Redação, } \\
\text { Matemática, } \\
\text { História, } \\
\text { Geografia e } \\
\text { Ciências } \\
\text { Naturais. Para o } \\
\text { EM: Linguagens, } \\
\text { Matemática, } \\
\text { Ciências da } \\
\text { Natureza e } \\
\text { Ciências } \\
\text { Humanas }\end{array}$ & Individual & $\begin{array}{c}\text { Certificação de } \\
\text { conclusão do } \\
\text { Ensino } \\
\text { Fundamental ou } \\
\text { do Ensino Médio }\end{array}$ \\
\hline $\begin{array}{c}\text { Programa } \\
\text { Internacional de } \\
\text { Avaliação dos } \\
\text { Estudantes } \\
\text { (PISA) }\end{array}$ & $\begin{array}{c}\text { Jovens de } 15 \\
\text { anos (idade em } \\
\text { que se pressupõe } \\
\text { o término da } \\
\text { escolaridade } \\
\text { básica } \\
\text { obrigatória) }\end{array}$ & A cada três anos & $\begin{array}{c}\text { Leitura, } \\
\text { Matemática, } \\
\text { Ciências, } \\
\text { Competência } \\
\text { Financeira e } \\
\text { Resolução } \\
\text { colaborativa de } \\
\text { problemas }\end{array}$ & Por país & $\begin{array}{c}\text { Avaliar a } \\
\text { qualidade da } \\
\text { educação nos } \\
\text { países } \\
\text { participantes }\end{array}$ \\
\hline
\end{tabular}

FONTE: PORTAL DO MEC (2017)

Os resultados da Avaliação Nacional da Educação Básica (Aneb), da Avaliação Nacional do Rendimento Escolar (Anresc, Prova Brasil) e da Avaliação Nacional da Alfabetização (ANA) são calculados pelo INEP oferecem informações sobre o desempenho das escolas de todo o país através do IDEB, que será tratado no seguinte subitem.

Durante a gestão de Francisco Soares no INEP de 2014 a 2016, para a divulgação dos dados de avaliação externa foi construído e incorporado o Indicador de Nível Socioeconômico (NSE) que interage com três resultados que concretizam a qualidade da 
educação: acesso, permanência e desempenho, no que diz respeito ao enfrentamento das desigualdades de oportunidades educacionais.

Até a introdução desses instrumentos que avaliavam os contextos, o SAEB valorizava apenas o papel das variáveis propriamente escolares, como a formação de professores e diretores, o estilo docente, o tempo dedicado ao ensino, a infraestrutura escolar, deste modo, subestimando o peso dos fatores socioeconômicos e culturais e a existência de relações estreitas entre fatores escolares e extraescolares no desempenho do aluno. Assim, nos seus primeiros ciclos, o SAEB deu importância à avaliação sobre as condições intraescolares intervenientes no desempenho do aluno, tendendo a se distanciar do levantamento sobre o problema das desigualdades educacionais associado a fatores extraescolares, cujos resultados enfatizavam a relação de fatores socioeconômicos e culturais sobre o fracasso e a evasão do aluno (FRANCO; BONAMINO, 1999).

Segundo Soares e Xavier (2013), o NSE capta de maneira adequada as condições econômicas dos municípios, o que justifica seu uso nas análises estatísticas para a caracterização das escolas.

Soares defende que

\begin{abstract}
As correlações entre o NSE e o Ideb são sempre positivas, mas o valor é mais alto entre escolas de um mesmo município do que entre municípios. Diante disso, a identificação de escolas com projetos pedagógicos exemplares não pode ser feita apenas com o Ideb, que, como visto, identifica também escolas que têm bons resultados apenas porque atendem a alunos que trazem muito do capital cultural de suas famílias (SOARES; XAVIER, 2013, p. 917).
\end{abstract}

Analisar as escolas através da hierarquização é uma opção metodológica frágil, segundo o autor, o que atesta a limitação do IDEB. Segundo ele a "solução é produzir e divulgar interpretações alternativas” (SOARES; XAVIER, 2013, p. 920).

No item seguinte, serão apontadas algumas posições em relação ao IDEB e críticas presentes no debate educacional a cerca de seu uso. 
2.1.2 O papel das avaliações em larga escala nas políticas de equidade e as tensões que envolvem o IDEB

O IDEB (Índice de desenvolvimento da Educação Básica), criado pelo INEP em 2007, articula em um mesmo indicador o fluxo escolar e o desempenho dos alunos, atribuindo-lhes um valor em uma escala de zero a dez. Ele sintetiza dois conceitos: aprovação e média de desempenho dos estudantes em língua portuguesa e matemática. A partir deste instrumento, o Ministério da Educação traçou metas de desempenho bianuais para cada escola e cada rede que hoje foram incorporadas ao novo Plano Nacional de Educação (Lei $n^{\circ}$ 13.005/2014).

A fixação da média seis para os anos iniciais do ensino fundamental, a ser alcançada em 2021 (meta 7), considerou o resultado obtido pelos países da Organização para a Cooperação e o Desenvolvimento Econômico (OCDE), quando se aplica a metodologia do IDEB em seus resultados educacionais. Seis $(6,0)$ foi a nota obtida pelos países desenvolvidos que ficaram entre os 20 mais bem colocados do mundo.

Segundo o Reinaldo Fernandes, sob cuja gestão no INEP o indicador foi criado, o IDEB “é um indicador educacional que relaciona de forma positiva informações de rendimento escolar (aprovação) e desempenho (proficiências) em exames padronizados” (FERNANDES, 2007), assumindo-se como importante condutor de política pública a favor da qualidade da educação e uma ferramenta para acompanhamento das metas de qualidade do Plano de Desenvolvimento da Educação - PNE e agrega ao enfoque pedagógico dos resultados das avaliações em larga escala do INEP a possibilidade de resultados sintéticos, facilmente assimiláveis, e que permitem traçar metas de qualidade educacional para os sistemas.

O IDEB é calculado a partir dos dados sobre aprovação escolar, obtidos no Censo Escolar realizado todos os anos, e médias de desempenho nas avaliações do INEP: a Prova Brasil (para IDEB de escolas e municípios), a Aneb (IDEB apresentado por regiões geográficas e unidades da federação) - avaliações aplicadas no $5^{\circ}$ e $9^{\circ}$ ano do Ensino Fundamental e no $3^{\circ}$ ano do Ensino Médio - e ANA, destinada à aferição do desenvolvimento dos níveis de alfabetização e letramento em Língua Portuguesa e Matemática dos estudantes do $3^{\circ}$ ano do Ensino Fundamental das escolas públicas.

De acordo com o INEP (2015), o índice, que é a combinação entre fluxo escolar e aprendizagem, tem o mérito de equilibrar as duas dimensões: se um sistema de ensino retiver seus alunos para obter resultados de melhor qualidade no SAEB, o fator fluxo será alterado, 
indicando a necessidade de melhoria do sistema. Se, ao contrário, o sistema apressar a aprovação do aluno sem qualidade, o resultado das avaliações indicará igualmente a necessidade de melhoria do sistema. Contudo, como se verá mais à frente, as relações entre as duas variáveis é bem mais complexa e requer a retomada da discussão sobre o caráter fiscalizador presente nos exames estandardizados.

O INEP declarou ${ }^{17}$ que, a partir de 2018, todas as escolas que participarem da aplicação censitária do $\mathrm{SAEB}^{18}$ (com público alvo ampliado em 2017) e que cumprirem critérios determinados teriam seu IDEB calculado e divulgado a cada dois anos, e que, o SAEB, então universalizado, deverá substituir a divulgação do Enem por Escola sob a justificativa de ser um instrumento mais adequado que o ENEM para avaliação de sistemas de ensino e escolas.

Só serão divulgados para a sociedade, de acordo com informações do Portal do $\mathrm{INEP}^{19}$, os resultados das escolas (com exceção das sorteadas como amostra) que, cumulativamente, tiverem pelo menos dez alunos presentes no momento da aplicação dos instrumentos e alcançarem uma taxa de participação de ao menos $80 \%$ dos alunos matriculados. Os resultados apresentam a distribuição percentual dos alunos em cada um dos níveis da escala de proficiência, por área do conhecimento, para escolas, municípios e estados, bem como os demais estratos de interesse da avaliação. Também serão divulgados indicadores sobre as condições em que ocorre o trabalho pedagógico escolar ${ }^{20}$.

Assim, o SAEB em 2017 passa a avaliar o ensino médio de forma censitária e não mais por amostragem. Logo, não só as escolas públicas de ensino fundamental, mas também as de ensino médio (públicas e privadas) tiveram cálculos individuais do IDEB.

Até 2015, os resultados do ensino médio, diferentemente do ensino fundamental, eram obtidos a partir de uma amostra de escolas. Pela primeira vez, o INEP passou a calcular o IDEB para as escolas de ensino médio. É, portanto, reiterada a já conhecida tendência dos reformadores, que apesar de não se oporem à validade dos resultados da avaliação amostral

\footnotetext{
17 Publicado no Portal do INEP em 20 de Abril de 2017. Disponível em: http://portal.inep.gov.br/artigo2//asset_publisher/GngVoM7TApe5/content/publicada-a-portaria-do-sistema-de-avaliacao-da-educacaobasica-saeb-/21206?inheritRedirect=false. Consulta realizada em 23/10/2017.

18 O SAEB ampliando sua abrangência passou a ser universal assumindo o tratamento dos dados do ensino médio, com a extinção da divulgação do ENEM por escola.

${ }^{19}$ Acessível em: http://portal.mec.gov.br/component/tags/tag/31992. Consulta realizada em 23/10/2017.

${ }^{20}$ Acessível em: http://portal.mec.gov.br/component/tags/tag/31992. Consulta realizada em 23/10/2017.
} 
em larga escala, apostam, sob a justificativa de um macro envolvimento da sociedade, na avaliação censitária.

Como já discutido, a avaliação censitária é comum nos países comprometidos com a política de responsabilização, que fiscaliza e identifica os atores envolvidos nos processos de aprendizagem respaldados em punições e premiações, acreditando assim, melhor cumprir a função de orientação das políticas educacionais públicas através da avaliação censitária, que localiza os problemas e aperfeiçoa possíveis correções. Daí o controle através de pressões sobre a escola e a carreira docente, um claro desvirtuamento do que deve constituir o real objetivo da avaliação, que deve pautar-se pelo uso dos resultados de desempenho em favor das políticas focadas no direito a uma educação de qualidade.

O SAEB, portanto, ao longo dos anos não assegurou que a qualidade das politicas educacionais fosse mantida ou que as políticas sejam melhoradas, pois progressivamente foi se vinculando aos resultados de testagem e índices, quando há fatores que interpelam a produção do desempenho que necessitam ser apurados e incorporados às políticas educacionais.

Na opinião de Soares e Xavier,

\begin{abstract}
O Ideb deve ser divulgado de forma contextualizada, que contenha pelo menos uma descrição do nível socioeconômico das escolas ou dos municípios. Idealmente, outras características das escolas, como sua infraestrutura, devem também ser consideradas. Isso não advoga que as expectativas relativas ao aprendizado dos alunos devem ser diferentes em diferentes municípios, mas apenas que, para atingir os aprendizados necessários, alguns cenários sociais são mais adversos do que outros. Além disso, junto com o Ideb, cada escola ou rede deve receber também uma descrição de quantos alunos estão em níveis de desempenho medíocres. Claro que escolas e redes com Ideb maiores do que 6,5 estão em uma situação privilegiada, pois esse valor não permite que muitos estudantes tenham aprendido muito pouco (SOARES; XAVIER, 2013, p. 920).
\end{abstract}

É necessário, portanto, considerar estudos sobre diferenças sociais e pesquisas sobre estratificação e o desenvolvimento de um índice de desenvolvimento socioeconômico, que significam, de acordo com Alves, Soares, e Xavier:

[...] uma contribuição a uma demanda que surge naturalmente, nos últimos anos, a partir da divulgação dos resultados educacionais por estabelecimentos de ensino [...]. O nível socioeconômico é um construto teórico que aloca os indivíduos em classes ou estratos sociais. Na literatura, não há uma definição unívoca desse construto, nem um consenso absoluto sobre quais dimensões devem ser consideradas para a sua operacionalização (ALVES; SOARES; XAVIER, 2014, p. 672). 
Diante do exposto, sabe-se que o SAEB possui forte relevância para a gestão de políticas públicas, contudo, envolve com insuficiência a explicação fatores extraescolares que perpassam o desempenho. Assim sendo, a mercantilização, padronização, terceirização, responsabilização são os conceitos que vêm compondo o cenário das avaliações promovidas por exames em larga escala hoje no Brasil, seguindo a mesma lógica de tantos outros países que aderiram ou que se submeteram à lógica concorrencial das políticas de cunho neoliberal (FREITAS, 2011).

Cabe lembrar que o IDEB sendo um indicador único e sintético possibilita o monitoramento de um sistema universal como o SAEB, no entanto, leva imediatamente ao uso de hierarquizações como forma de análise da realidade educacional, fazendo com que a ampla divulgação limite o acompanhamento da sociedade aos rankings (SOARES; XAVIER, 2013).

Sendo o IDEB um instrumento que identifica níveis de aprendizagem dos conteúdos presentes no sistema educacional, certamente teria que ponderar sobre os aspectos que têm impacto direto e indireto sobre a educação, como as diferenças socioeconômicas e culturais dos alunos, que também incidem na análise explicativa da diferença de desempenho das escolas, pois omitir o nível econômico e o capital cultural da comunidade atendida pela escola é desconsiderar o verdadeiro trabalho desenvolvido nesse ambiente de ensino (FIGUEIREDO et al., 2018).

Ainda que os resultados do ENEM não produzam os chamados índices considerados medidores da qualidade do ensino, como o IDEB, a formação do ranking das posições das médias de desempenho das escolas brasileiras durante anos concedeu à sociedade um parâmetro equivocado de qualidade do ensino, usado como propaganda para escolas particulares até 2017, quando foi extinta a divulgação do ENEM por Escola.

No capítulo que se segue, pretendeu-se traçar a trajetória do ENEM no contexto das políticas para o ensino médio no Brasil. Serão discutidas suas respectivas reformas e reconfigurações através dos marcos legislativos, e a amplitude do exame em relação àquilo que passou a ser uma de suas finalidades primordiais: o ingresso no Ensino Superior. 


\title{
3 O ENEM NO CONTEXTO DAS POLÍTICAS PARA O ENSINO MÉDIO NO BRASIL
}

Este capítulo se dedica a esboçar um panorama do Ensino Médio no Brasil através de seus aspectos históricos, pressupostos, identidade e perspectivas na intenção de contextualizar o papel que o ENEM foi progressivamente assumindo tendo em vista o público a que se destina a esta etapa de ensino.

Para tanto, tomou-se o Ensino Médio como categoria de análise reconhecendo primordialmente, segundo Silva,

\begin{abstract}
A compreensão do lugar central que ocupa o ensino médio no cenário educacional, dos mais variados países, deriva do acertado reconhecimento das controvérsias que cercam a definição de políticas para essa etapa da escolarização, bem como dos distintos agentes que protagonizam essa definição (SILVA, 2015, p. 249).
\end{abstract}

À frente, procurou-se traçar a trajetória do Exame Nacional do Ensino Médio através de alguns aspectos técnicos perpassados pelos marcos normativos que lhe conferiram importantes mudanças no âmbito das políticas educacionais e por fim, adentrar na discussão sobre a hierarquização de resultados e o polêmico ranking.

\subsection{ENSINO MÉDIO NO BRASIL: UMA DUALIDADE NÃO RESOLVIDA}

De início, conforme anunciam estudos sobre o ensino médio no Brasil, esta etapa tem como marca, desde a sua concepção até os dias atuais, os desencontros e dualidades refletidos pela sua ausência de identidade em razão de serem seus objetivos equacionados através de uma leitura ambígua da sua história: ora denomina-se etapa de transição ao ensino superior (para a elite), ora assumia a função de formação profissional (para a classe trabalhadora).

Assim, não apenas às diferentes finalidades e objetivos, mas, a diferenciação das demandas do Ensino Médio, Kuenzer discorre sobre o conceito de dualidade estrutural que

[...] configura-se como a grande categoria explicativa da constituição do Ensino Médio e profissional no Brasil, legitimando a existência de dois caminhos bem diferenciados a partir das funções essenciais do mundo da produção econômica: um, para os que serão preparados pela escola para exercer funções de dirigentes; outro, para os que, com poucos anos de escolaridade, serão preparados para o mundo do trabalho em cursos específicos de formação profissional, na rede pública ou privada. (KUENZER, 1997, p. 28-29). 
Para analisar os processos e políticas educacionais que contornam este cenário controverso do Ensino Médio que estende até a atualidade, admite-se a importância de rever brevemente aspectos históricos e políticos do sistema de ensino brasileiro responsáveis pela dualidade circular desde o Brasil colônia. Para tanto, recorreu-se ao trabalho de Pinto (2002) que se debruça sobre a evolução desta etapa de ensino no Brasil, condição essencial para entender sua dualidade histórica.

O monopólio do ensino designado aos jesuítas desobrigava Portugal de custeá-lo, já que a metrópole não tinha interesse no Brasil colonial até se dar conta do seu potencial exportador, com descoberta da monocultura da cana-de-açúcar e a mineração. É importante salientar que a exploração econômica na colônia era sustentada pelas bases de produção do trabalho escravo e do latifúndio, logo, o trabalho escravo, que então parecia suficiente para atender à avidez dos exploradores, excluía a população de negros, índios e pobres do acesso à formação reservada à elite rural (PINTO, 2002).

O padrão de ensino jesuítico consistia na expansão de fiéis católicos através de um ensino formalista e hermenêutico e era destinado aos herdeiros das elites locais preparando-os para ingressar em cursos superiores na Europa. "Portanto, o ensino médio no Brasil já nasce com um caráter seletivo, propedêutico [...], características que, em linhas gerais, estão presentes até hoje” (PINTO, 2002, p. 52).

Tempos após a reforma pombalina, o país passou por importantes mudanças políticas, como a vinda da família real, sem que se alterasse o modelo de colonização de exploração. Dessa forma, viu-se atendidos os anseios da elite portuguesa - que exigia manter seu padrão cultural e de instrução - aqui instalada e nasceram assim os primeiros cursos superiores.

Poucas mudanças ocorreram no Ensino Médio no Brasil imperial até a promulgação do Ato Adicional à Constituição em 1834. Este Ato dividiu a responsabilidade na oferta do ensino, deixando as províncias responsáveis pelo ensino primário e secundário, o que corroborou com a fundação de vários liceus provinciais, ficando o governo central com a educação superior.

De acordo com Pinto (2002), apenas com a Revolução de 30 e com as políticas de fomento à industrialização na Era Vargas e, o Brasil viu mudanças no contexto educacional. Instituiu-se o Ministério da Educação liderado por Francisco Campos e em 1931, durante o governo provisório, deu-se o decreto $\mathrm{n}^{\circ} 19.890$ que dispunha sobre a organização do ensino secundário que foi anos depois complementado por Gustavo Capanema com a Lei Orgânica do Ensino Secundário (Lei ${ }^{\circ} 4.244$ de abril de 1942). "Para se avaliar a seletividade do 
sistema, os alunos que concluíam o ensino primário tinham que se submeter a um exame (exame de admissão) para o ingresso no ginásio. Em caso de reprovação, deveriam cursar um ano de estudo complementar” (PINTO, 2002, p. 54).

A Era Vargas, em resposta ao processo de industrialização, implantou o ensino profissionalizante destinado às camadas populares. Em 1942, inclusive, foi também criado o Serviço Nacional de Aprendizagem Industrial (Senai), sob controle dos empresários, sistema que foi ampliado para os outros ramos de atividade econômica e perdura até hoje. Consolidou-se, então, um sistema dualista que dividiu o cenário do Ensino Médio: ensino profissionalizante para pobres e ensino propedêutico para as elites que visavam o ingresso no Ensino Superior (PINTO, 2002).

O golpe militar de 1964 e a ditadura impactaram fortemente na organização da educação no Brasil, em especial, o Ensino Médio. A Lei 5.692/71 criou dois blocos que correspondem à educação básica: primeiro grau (unindo primário e ginasial) e segundo grau, que correspondia ao colegial com três anos de duração. Esta lei implanta ainda a profissionalização compulsória, que também decidia sobre o fim de trajetórias acadêmicas dando ao Ensino Médio caráter de terminal com o papel de oferecer compulsoriamente uma formação profissional a todos os alunos de escolas públicas ou privadas. Tratava-se também de uma maneira de silenciar a voz das manifestações dos movimentos estudantis que bradavam por mais vagas em universidades públicas. Sobre esse viés, Queiroz e Moita afirmam:

\footnotetext{
A Lei $n^{0} 5692 / 71$, ao propor a universalização do ensino profissionalizante, pautada pela relação de complementaridade entre ideologia tecnicista e controle tecnocrático, almejou o esvaziamento da dimensão política da educação, tratando-a como questão exclusivamente técnica, alcançando, ao mesmo passo, a contenção da prole trabalhadora em níveis inferiores de ensino e sua marginalização como expressão política e reivindicatória (QUEIROZ; MOITA, 2007, p. 11).
}

Ademais, diante da lógica desenvolvimentista do capital, o papel da escola era reservado à formação meramente técnica do trabalhador e passou a valorizar a capacitação dos indivíduos com vistas à sua ascensão social. Tratava-se da absorção do discurso economicista pela educação que apostava no acúmulo de capital humano visando o melhor desempenho no mercado de trabalho sob a forma de doutrinação tecnicista. Cabia, portanto, à população se responsabilizar pela busca de instrução para atender às exigências do avanço tecnológico no mundo do trabalho e assim perseguir melhorias salariais. "Nesta lógica, os professores [da rede privada de ensino], assim como os demais trabalhadores do setor de 
serviços, cumprem a função de gerar mais-valia para os novos capitalistas da educação" (PINTO, 2002, p. 56).

Para Frigotto,

Do ponto de vista macroeconômico, o investimento no "fator humano" passa a significar um dos determinantes básicos para o aumento da produtividade e elemento de superação do atraso econômico. Do ponto de vista microeconômico, constitui-se no fator explicativo das diferenças individuais de produtividade e de renda e, consequentemente, de mobilidade social (FRIGOTTO, 1993, p. 41).

Tendo em vista as pressões das elites e classes médias que não estavam interessadas em um ensino médio de caráter profissional e terminativo foi promulgada a Lei ${ }^{0}$ 7.044/82 que revogou a compulsoriedade prevista na Lei 5.692/71.

Com base neste pano de fundo, entre os principais norteadores para a expansão do Ensino Médio introduzida pela Constituição Federal de 1988 e pela Lei de Diretrizes e Bases da Educação de 1996, pode-se elencar: a necessidade crescente de tornar o país competitivo no cenário internacional e as novas exigências do mercado quanto à elevação dos níveis de escolarização e a adequação do jovem aos avanços tecnológicos (MESQUITA, LELIS, 2015).

Disputas nos campos conservadores e progressistas da educação trouxeram a eminência de uma proposta educacional que estivesse retratada em uma Constituição Federal com a atualização da LBD determinando responsabilidades dos entes federados e a abrangência do Ensino Médio. Diante disso, a Constituição Federal de 1988 em sua redação original estabelece como obrigação do Estado garantir a progressiva universalização e gratuidade do ensino médio.

Segundo Pinto (2002), consonante ao texto da Constituição Federal de 1988, a LDB de 1996, assegura a oferta pela rede privada, desde que se subordine às normas gerais da educação nacional e seja autorizada a avaliação da qualidade por parte do poder público e possua capacidade de autofinanciamento, com ressalva nos casos previstos em lei das instituições confessionais, comunitárias e filantrópicas (CF, Art. 209 e LDB, Art. $7^{\circ}$ ). A responsabilidade da oferta do ensino médio público passa a ser dos governos estaduais, cabendo à União a importante função de assegurar a equalização das oportunidades educacionais entre as diferentes regiões do país e de garantir um padrão mínimo de qualidade mediante assistência técnica e financeira (CF, Art. 211 e LDB, Art. 10).

O Ensino Médio até a redemocratização do país na década de 1980, segundo Franco e Bonamino (1999), limitava-se à continuidade do ensino fundamental e à escolaridade 
mínima que pudesse corresponder aos avanços tecnológicos da década, ganhando destaque apenas nas reformas educacionais.

Embora as demandas dos sistemas educativos brasileiros apontassem para a necessidade de reformas profundas e urgentes, principalmente no que concerne ao período de democratização do acesso à educação, vale ressaltar que afirmar que as reformas ocorreram a partir do imperativo do processo de globalização não significa diminuir a sua importância para a consolidação da educação como direito dos brasileiros (CLEMENTE; SOUZA, 2016).

Segundo as ponderações de Frigotto,

A consolidação do bloco conservador no poder [...] articula às reformas do Estado um projeto educacional, da pré-escola à pós- graduação, ajustando à nova era do mercado. Um projeto alheio aos anseios históricos da sociedade brasileira, fundado nas diretrizes político-administrativas e pedagógicas dos organismos internacionais, mormente o Banco Mundial. Este [...] constitui-se hoje, no intelectual coletivo formulador da política educacional, para os países que necessitam do ajuste estrutural, dando as diretrizes da organização, as propriedades e os conteúdos (FRIGOTTO, 1999, p.224).

Pressionado pelos requisitos exigidos para o ingresso no ensino superior, o Ensino Médio assumiu a tarefa e a finalidade de completar a educação básica, preparando os jovens para a profissionalização. Este aspecto crucial na história do Ensino Médio no Brasil verificase na discussão sobre as suas finalidades em face às prioridades acordadas nos anos 90 e nos redirecionamentos curriculares e por meio de acordos necessários aos arranjos da globalização (SAMPAIO; MARIN, 2004).

Para as autoras supracitadas,

\begin{abstract}
Compreender as práticas curriculares nesta perspectiva, atravessadas pelas exigências da nova ordem econômica e política, torna-se necessário, ainda que difícil. Exige conhecer e analisar o currículo prescrito e, sobretudo, investigar o currículo real, aquele que se desdobra em práticas no interior da escola, cuja determinação não se origina apenas das prescrições oficiais, mas de muitos fatores que interferem no desenvolvimento do trabalho escolar. Seus determinantes expressam tanto as marcas das políticas quanto as condições e os problemas sociais e econômicos que atingem a vida de seus usuários (SAMPAIO; MARIN, 2004, p. 1205).
\end{abstract}

Diante dessa realidade, observa-se que o Ensino Médio projetado pelos países ricos não corresponde às exigências do mundo do trabalho no Brasil. A parametrização de conteúdos que impõem um perfil de cultura cada vez mais calcado na tecnologia e no tensionamento entre o conhecimento legitimado e a "era da informação" fazem da escola um ente seletivo que privilegia determinados grupos e exclui outros. 
Com isso, o Ensino Médio de baixa qualidade se aproximou de um ensino esvaziado de criticidade e princípios de cidadania formando jovens de raso aprount, destinados a ocupar postos subalternos na vida profissional. Para isso, se faz até hoje urgente pensar para o Ensino Médio um currículo integrado que trate os conteúdos com fidelidade às suas bases epistemológicas e que se atrele ao mesmo tempo ao mundo do trabalho.

As matrículas do Ensino Médio começaram a decrescer em 2007 e este fenômeno se deve à perda do significado do Ensino Médio, principalmente para aqueles que vivem do trabalho. Com a ruptura da Educação Profissional e Ensino Médio, ocorrida a partir da LDB, a escola não atende mais aos anseios de mobilidade social presentes na juventude (KUENZER, 2010).

É preciso colocar também outros fatores que justifiquem a queda na adesão dos jovens à escola média, como o fato de a EJA, que também vive atualmente a queda de matrículas, se apresentar como uma possibilidade de terminalidade mais rápida por ser mais atraente para a maioria dos alunos trabalhadores e também alunos desempregados. A falta de condições materiais para frequentar a escola está principalmente associada à situação de classe, às dificuldades de integrar o trabalho e a escola, e à perda de sentido da escola (KUENZER, 2009).

Portanto, é correto admitir que a escola não seja capaz de romper com a dualidade estrutural, pois ela é necessária aos aparatos do capitalismo.

Para Kuenzer (2011), a discussão da qualidade do Ensino Médio remete à análise da concepção voltada aos que vivem do trabalho, tomando como referência a dualidade estrutural e seus impactos.

Acrescenta a autora:

a superação da dualidade não é uma questão a ser resolvida através da educação,
mediante novas formas de articulação entre o geral e o específico, entre teoria e
prática, entre disciplinaridade e transdisciplinaridade; ou mediante uma nova
concepção de competência que impacte as políticas e programas de formação de
professores. A dualidade só será superada com a superação da contradição entre a
propriedade dos meios de produção e a propriedade da força de trabalho. Embora,
como em todo processo contraditório, haja espaço para processos emancipatórios, é
preciso reafirmar que o estatuto da escola burguesa se constrói, historicamente, à
luz das demandas de valorização do capital, para o que os processos de capacitação
ou disciplinamento da força de trabalho são vitais (KUENZER, 2011, p. 49).

Portanto, é dever pactuar com as conclusões da autora quando afirma

que as dificuldades que têm pautado os processos de construção de uma proposta de qualidade para o ensino médio integrado, na perspectiva dos que vivem do trabalho, não podem ser resolvidas por soluções pedagógicas, uma vez que a 
ruptura entre o geral e o profissional, entre o trabalho intelectual e a atividade prática, está na raiz da constituição do modo de produção capitalista (KUENZER, 2011, p. 49).

O que é possível concluir é que o campo da avaliação inteiramente responsivo às reformas de cunho liberal recebe um público vindo de uma histórica segmentação social originada no seio da nossa colonização. O trabalho escravo como base produtiva e a terra como meio de produção pertencente às elites ditaram a dualidade primordial em relação à oferta de escolarização e dividiu em dois modelos de educação que deram o destino da classe trabalhadora à exclusão.

Assim, vê-se fortalecida a desigualdade de oportunidade nos processos de seleção travestidos em exames padronizados com o intuito de constatar o que já se sabe: a realidade dual é circular e ressurge cada vez mais forte, ao passo que disponibilizar vagas para todos não é suficiente para que os filhos da classe trabalhadora frequentem a escola. Isto se dá principalmente pela ausência de mecanismos de apoio da escola ao jovem pobre e trabalhador. Portanto, a discutida crise de identidade do Ensino Médio brasileiro e a falta de interesse dos jovens se explicam, fatalmente, através dos fatores socioeconômicos que perpetuam a imobilidade social, sendo assim a universalização uma meta insuficiente e excludente quando a oferta é de baixa qualidade. O ENEM e suas mudanças só podem ser entendidos dentro desse contexto.

\subsection{ENEM: TRAJETÓRIA E TENSIONAMENTOS}

A relação avaliação/qualidade é inserida no contexto educacional a fim de confirmar valor à educação como condição da inserção competitiva dos países no mercado. Sobre a avaliação do Ensino Médio, o Art. $9^{\circ}$ da LDB estabelece que cabe à União assegurar processo de avaliação de rendimento escolar no Ensino Fundamental, Médio e Superior objetivando a definição de prioridades e a melhoria da qualidade.

O Exame Nacional do Ensino Médio, criado para medir os conhecimentos dos jovens sobre conteúdos inerentes à formação para a vida, foi instituído pela Portaria MEC n 438, de 28 de maio de 1998 nos seguintes termos:

\footnotetext{
Artigo $1^{\circ}$ - Instituir o Exame Nacional do Ensino Médio - ENEM, como procedimento de avaliação do desempenho do aluno, tendo por objetivos:

l - conferir ao cidadão parâmetro para autoavaliação, com vistas à continuidade de sua formação e à sua inserção no mercado de trabalho;
} 
II - criar referência nacional para os egressos de qualquer das modalidades do ensino médio;

III - fornecer subsídios às diferentes modalidades de acesso à educação superior;

IV - constituir-se em modalidade de acesso a cursos profissionalizantes pósmédio (BRASIL, 1998).

Em 2009, 11 anos depois, portanto, a Portaria do INEP $\mathrm{n}^{0}$ 109, de 27 de maio reestrutura os objetivos do ENEM:

Art. $2^{\circ}$. Constituem os objetivos do ENEM:

$\mathrm{V}$ - Oferecer uma referência para que cada cidadão possa proceder à sua autoavaliação com vistas às suas escolhas futuras, tanto em relação ao mundo do trabalho quanto em relação à continuidade dos estudos;

VI - Estruturar uma avaliação ao final da educação básica que sirva como modalidade alternativa ou complementar aos processos de seleção nos diferentes setores do mundo do trabalho;

VII - Estruturar uma avaliação ao final da educação básica que sirva de modalidade alternativa ou complementar aos exames de acesso aos cursos profissionalizantes, pós-médios e à Educação Superior;

VIII - Possibilitar a participação e criar condições de acesso a programas governamentais;

IX - Promover a certificação de jovens e adultos no nível de conclusão do ensino médio nos termos do artigo 38, $\S 1^{\circ}$ e $2^{\circ}$ da Lei n. 9.394/96- Lei de Diretrizes e Bases da Educação Nacional (LDB);

$X \quad$ - Promover avaliação de desempenho acadêmico das escolas de ensino médio, de forma que cada unidade escolar receba resultado global;

XI - Promover avaliação de desempenho acadêmico dos estudantes ingressantes nas Instituições de Educação Superior (BRASIL, 2009).

Observada a acentuada mudança, consuma-se a percepção de que "este exame, que poderia cumprir uma importante, embora limitada, função diagnóstica do ensino médio, tem este objetivo distorcido quando o MEC busca transformá-lo em instrumento de seleção para o ingresso nas instituições superiores” (PINTO, 2002, p.58).

Em meio a este novo caráter do ENEM despontam as diferenças entre os resultados de alunos de escolas públicas e privadas onde o desempenho no exame apresentado como indicador de qualidade do ensino das escolas é usado como pretexto para a seletividade e exclusão nunca expurgadas do Ensino Médio no Brasil. Em vista disso, é prudente destacar as correspondências entre a “entidade” ENEM e a natureza do Ensino Médio. Para isso, é essencial deter-se à analise profunda sobre a sua clientela.

Anuente ao pensamento de Kuenzer ${ }^{21}$ faz-se premente a reflexão sobre os limites dos exames padronizados que priorizam a medição da capacidade de memorização e a competência em solucionar problemas e sobre o que de fato significa o conhecimento para o

${ }^{21}$ KUENZER, A. Os desafios da universalização da Educação Básica. Salto para o Futuro. Não paginado. Disponível em: https://api.tvescola.org.br/tve/salto-acervo/interview?idInterview=8501. Acesso realizado em 03/01/2019. 
seu público, pois, as relações sociais determinam as relações pedagógicas a partir dos perfis desse público. "Imaginar que clientelas tão diferentes, oriundas de classes sociais, de experiências, de relações com o conhecimento, com a cultura tão diferenciadas possam ser avaliadas por um único instrumento é, de fato, uma certa ingenuidade” (KUENZER, 2011, s/p.).

O ENEM por meio de suas modificações constitui-se em uma avaliação que busca aferir habilidades referenciadas em documentos legais e curriculares. Nesse sentido, o ENEM passou a balizar as práticas pedagógicas do professor tanto no ensino fundamental, quanto no médio, uma vez que, a ampliação dos seus objetivos tem origem nos princípios orientados pelas políticas curriculares apontando para a necessidade de sua reformulação. (CLEMENTE; SOUZA, 2016).

Levado como um instrumento governamental de aferição de qualidade, o ENEM não prioriza diagnosticar as dificuldades e possibilidades reais dos estudantes das escolas tidas como deficitárias ou ainda perceber os aspectos positivos, aprimorá-los e distribuir a todos, mas revela forma ainda maior de segregar indivíduos e classes, bem como reproduzir um sistema educativo com falhas, que são usadas economicamente pelos setores privados (MACEDO; MEDEIROS, 2011).

Os setores privados, segundo as autoras,

\begin{abstract}
Encontram aí um "filão de mercado" para dar aos sujeitos, com educação formal precária, os conhecimentos e habilidades necessárias para que o acesso ao mundo do trabalho se dê, apenas, na possibilidade de subempregos, para os quais os instrumentos públicos e escolas contribuem. Há uma reprodução da situação que mantém o status quo. O governo tem índices frios para mostrar às instituições internacionais de financiamento, além da ONU, que diz estar promovendo "educação de qualidade" ou proporcionando oportunidade a todos; por outro lado as grandes corporações e empresas encontram indivíduos treinados, alienados e "educados" para produzir sem contestar sua exploração social e seu status de mercadoria reprodutora do mundo capitalista. (MACEDO; MEDEIROS, 2011, p. 09).
\end{abstract}

A concepção de “Estado avaliador” é fortalecida sob o entendimento de que o Estado pretende em primeira instância comprovar eficácia de seus serviços educacionais reconhecendo suas fragilidades, e não a concretude da aprendizagem e formação dos estudantes, a esse respeito Alves afirma que:

Há uma poderosa máquina de implementação de políticas públicas, ancorada na questão da avaliação. Tem-se até chamado essa concepção de "Estado avaliador”. Ou seja, há um movimento no sentido de abandonar o controle de tipo burocrático que o Estado normalmente utilizava e avançar para um controle que é feito a partir 
dos processos de avaliação, ou seja, o estado coloca as grandes políticas públicas, os grandes conceitos. A partir daí ele desenvolve sistemas de avaliação. Tais sistemas de avaliação alimentam as bases de dados dos órgãos elaboradores de políticas e estes tomam decisões, na outra ponta, que afetam o financiamento recebido pelas instituições. Aí fecha-se o circuito. Fixam políticas, definem processos de avaliação e discutem acesso a recursos em função do resultado do processo avaliativo (ALVES, 2009, p. 17).

Assim, torna-se possível a compreensão de que a avaliação buscava dar visibilidade às ações do Estado e à sua capacidade em atender e administrar as demandas sociais com responsabilidade de garantir a todos os cidadãos acesso aos serviços básicos oferecidos.

Para Gentili (2001, p. 115), “com contraface do discurso da democratização no campo educativo, o discurso da qualidade foi assumindo a fisionomia de uma nova retórica conservadora funcional e coerente com o feroz ataque que hoje sofrem os espaços públicos”. Zanchet (2003) ainda reforça que o eixo da discussão sobre a qualidade do ensino como direito dos cidadãos altera o foco para a discussão das questões que articulam educação com produtividade e competitividade.

Como partícipe da mesma lógica do SAEB, o ENEM possui como característica primordial a ênfase nos produtos e resultados do desempenho dos alunos, atribuição de mérito e tomada de dados predominantemente quantitativos.

Sendo assim, a avaliação estabelece que a competitividade, traduzida pelo estabelecimento de um ethos regulador, gera qualidade. Ou seja, quem assume a função de encorajar a produção da qualidade e regular os sistemas educativos é o Estado que as concretiza por meio dos sistemas de avaliação. A centralidade significativa que o Estado passa a dar para a avaliação permite-nos inferir que, na sua concepção, a avaliação é capaz de garantir, através do estabelecimento de um ethos, produtos que assegurem a eficiência e a produtividade dos sistemas educacionais, onde o mercado é o principal definidor dos critérios de qualidade. Nesse âmbito, a qualidade que se desprende daí é aquela que atende aos princípios estabelecidos pelo mercado. (AFONSO, 1998).

A avaliação passa a ser o instrumento onde os exames estandardizados de rendimento prestam contas sobre a eficácia dos serviços públicos. É neste contexto que, como lembra Dias Sobrinho (2000, p. 141), “a avaliação passa a ter uma importância cada vez maior, na medida e no controle da eficiência e da produtividade das instituições educacionais”.

A centralidade dada à avaliação externa nas políticas educativas possibilita compreender a concepção do Estado avaliador e seu cunho regulatório como via 
comprobatória de seus resultados e metas alcançadas que são divulgadas à sociedade, portanto, como um forte meio de controle social.

O ENEM tem sido costumeiramente denominado como avaliação. No entanto, existem discussões a respeito das diferenças entre avaliação, aferição, verificação de resultados, evidenciando que exames dessa natureza não podem ser tratados como avaliação, mas sim, como processo de aferição ou verificação de resultados (ZANCHET, 2003).

Em uma aproximação desse enfoque da avaliação com a especificidade do ENEM, poderíamos pensá-lo como uma avaliação se fosse considerado a idiossincrasia que o envolve, uma vez que esse enfoque concebe o ensino como um conjunto de técnicas que conduzem a um fim pré-determinado. No caso do ENEM, ao invés dos objetivos adjacentes às habilidades de aprendizagem, o exame volta-se à notória divulgação dos resultados da prova (ZANCHET, 2003).

Aprofundando a análise sobre a classificação como avaliação, Dias Sobrinho (2000), ao referir-se a exames nacionais, adverte que medir não é a mesma coisa que avaliar, é apenas parte de um processo muito mais amplo; um procedimento isolado não é, em si, um programa formativo.

Perrenoud (1999) argumenta que não é possível avaliar competências de maneira padronizada, deste modo, deve-se renunciar à organização de uma prova de competências colocando-se todos os “concorrentes" no mesmo ponto de largada.

Sobre o impacto da competitividade organicidade das políticas curriculares, cabe ressaltar a tendência à roteirização das práticas de ensino que debruçam naquilo que será cobrado na prova e esforços de se obter bons resultados.

Conforme afirma ZANCHET (2003),

\begin{abstract}
Essa lógica, não tem muita importância a aprendizagem do aluno, mas sim o seu desempenho na prova, pois esse sim poder ser medido. Reduzir a avaliação à aplicação de um exame é reforçar uma visão mecanicista e simplificadora, constituída como uma tecnificação da formação. Essa perspectiva é responsável pela proliferação das provas de rendimento e das escalas de atitudes, onde as metas estão predeterminadas e os fins estão fixados, delegando à avaliação a medição do êxito nos resultados obtidos. [...] A comparabilidade apresentada no boletim de resultados evoca, entre os participantes, a competitividade no plano individual, deixando de lado os valores de solidariedade e de construção coletiva necessários à emancipação. (ZANCHET, 2003, p. 259).
\end{abstract}

O ENEM, portanto, concebido em meio às reformas educacionais da década de 1990, articula o circuito regulatório, fiscalizador do trabalho docente que faz do currículo refém de seus objetivos reais. Ademais, propõe-se a avaliar competências que estejam alinhadas ao 
mundo da produção e atuação no mercado. A engrenagem do Estado neoliberal tem como primazia regular os sistemas de educação, desconsiderando a realidade brasileira promovendo-se através da perigosa noção de qualidade revelada pelos exames estandardizados.

O ENEM é um exame constituído a partir de uma matriz de habilidades e competências que sintetizam os conteúdos ministrados na educação básica e as médias por escola são divulgadas em rankings de escolas de acordo com as médias obtidas através do cálculo da nota dos candidatos (SOUSA, 2011).

Sousa afirma que o ENEM não pode ser considerado um exame que avalia o EM, pois, embora venha sendo difundido como exame para essa etapa do ensino, seus resultados não evidenciam a qualidade do ensino médio, cujos objetivos (tanto na sua versão antiga quanto a nova) refletem "[...] o propósito de avaliar individualmente alunos concluintes e egressos do ensino médio quanto às competências especialmente definida para esse exame” (SOUSA, 2011, p. 102).

De acordo com Zanchet (2003, p. 261), diante dessa nova perspectiva, as mudanças delegadas às escolas não poderiam ocorrer com base em mudanças estruturais, mas, sim, com base na reflexão sobre os conteúdos que proporcionam o desenvolvimento de competências que permitirão aos jovens sua inserção no mercado de trabalho.

Segundo a autora,

\begin{abstract}
A discussão em torno do desenvolvimento aprofundado de conteúdos disciplinares, enfatizada em anos anteriores, é substituída na escola, por um discurso que afirma que a transmissão do conhecimento já não é apenas monopólio do professor. A tecnologia da informação e o mundo das empresas assumem o compromisso com a informação e delegam à escola, através do trabalho do professor, o papel de objetivar o desenvolvimento de competências através das quais os alunos possam melhor assimilar essas informações. (ZANCHET, 2003, P. 261).
\end{abstract}

Nesse sentido, a reconfiguração do Ensino Médio se dá ao mesmo tempo em que se instaura a cultura da avaliação em larga escala no Brasil direcionada aos estudantes egressos da educação básica, potenciais ingressantes no mercado de trabalho. Assim, a escola passa a objetivar competências que o mercado profissional exige e que passam a ser aferidas pelo Exame nacional do Ensino Médio. vista:

De acordo com o INEP/MEC (1999), a criação do ENEM se justificava tendo em

O objetivo fundamental de avaliar o desempenho do aluno ao término da escolaridade básica, para aferir o desenvolvimento das competências funda mentais ao exercício pleno da cidadania. Pretende, ainda, alcançar os seguintes objetivos 
específicos: a oferecer uma referência para que cada cidadão possa proceder à sua autoavaliação com vista às escolhas futuras, tanto em relação ao mercado de trabalho quanto em relação à continuidade de estudos; b. estruturar uma avaliação da educação básica que sirva como modalidade alternativa ou complementar aos processos de seleção nos diferentes setores do mundo do trabalho; c. estruturar uma avaliação da educação básica que sirva como modalidade alternativa ou complementar aos exames de acesso aos cursos profissionalizantes pós-médios e ao ensino superior (INEP/MEC, 1999, p. 2).

A preparação da prova baseava-se em uma matriz de competências que objetivava romper com o isolamento das disciplinas do ensino médio e promover a colaboração, complementaridade e integração entre os conteúdos das diversas áreas do conhecimento presentes nas propostas curriculares das escolas brasileiras de ensino fundamental e médio (INEP/MEC, 1999).

A matriz de competências do ENEM em sua versão inicial, segundo Zanchet (2003), tinha como intenção levar em consideração a expressão dos princípios que organizam a passagem de um ensino centrado em saberes disciplinares a um ensino definido pela produção de competências que seriam verificadas através das questões da prova do ENEM.

De sua primeira edição, em 1998, até 2008, o ENEM era realizado anualmente, com a aplicação de uma única prova. A partir de 2009, através da Portaria no 109, de 27 de Maio de 2009 que institui um “novo ENEM”, ocorreu a reformulação metodológica do ENEM e sua utilização como forma de seleção unificada nos processos seletivos de muitas universidades federais. Reformularam-se as Matrizes de Referência do exame, agora estruturadas por competências em quatro áreas do conhecimento - Linguagens, Códigos e suas tecnologias, Matemática e suas tecnologias, Ciências Humanas e suas tecnologias e Ciências da Natureza e suas tecnologias - apresentando, ainda, eixos cognitivos comuns a todas as áreas ${ }^{22}$.

O exame divide-se, hoje em quatro provas objetivas sobre as áreas de conhecimento acima citadas, contendo, cada uma, 45 questões de múltipla escolha, e uma redação. Desde 2009, a proficiência dos participantes do Enem nas provas objetivas é calculada por meio da teoria de resposta ao item (TRI). Além de estimar as dificuldades dos itens e a proficiência dos participantes, essa metodologia permite que os itens de diferentes edições do exame sejam posicionados em uma mesma escala, segundo publicação de 2013 do INEP ${ }^{23}$.

Os procedimentos de análise dos itens e de cálculo das proficiências no ENEM têm como base a Teoria de Resposta ao Item (TRI) que modela a probabilidade de acerto do

\footnotetext{
${ }^{22}$ Disponível em: http://portal.inep.gov.br/web/enem/sobre-o-enem. Consulta realizada em 15/12/16.

23 Disponível em:http://inep.gov.br/artigo//asset_publisher/B4AQV9zFY7Bv/content/inep-cria-sistema-paraexplicar-o-calculo-da-nota-do-exame/21206. Consulta realizada em 15/12/2016.
} 
participante do exame. No ENEM, o cálculo da proficiência a partir do uso da TRI permite acrescentar outros aspectos além do quantitativo de acertos, tais como os parâmetros dos itens e o padrão de resposta do participante. Assim, duas pessoas com a mesma quantidade de acertos na prova são avaliadas de formas distintas a depender de quais itens estão certos e errados e podem, assim, ter habilidades diferentes.

A TRI, segundo sustenta o INEP, tem bases científicas e garante uma avaliação do conhecimento do participante de forma mais justa do que a Teoria Clássica, e apesar da alta complexidade dos cálculos matemáticos e estatísticos, o INEP garante o seu alto grau de confiabilidade nos resultados divulgados.

Diferentemente do padrão das avaliações mais tradicionais, em que o número total de acertos corresponde com precisão à média final atingida pelo aluno, a abordagem para a contagem da nota individual corrige eventuais desvios com base na dificuldade das questões formuladas para o exame, na maior ou menor habilidade apresentada pelo estudante e demais candidatos, além de desvalorizar o acerto casual.

No caso do ENEM, suas 180 questões atuais são retiradas de um extenso conjunto de questões - o Banco Nacional de Itens. Quando o aluno tem contato com elas, no dia da prova, os itens (questões) já foram classificados previamente de acordo com o nível de dificuldade, a partir de um critério estatístico que levou em conta a resolução por vários alunos do Ensino Médio. Portanto, cada item tem uma “carga estimada” e, dependendo de suas propriedades, terá um diferente peso na pontuação geral do aluno, de acordo com a comparação sistemática com os outros acertos e erros cometidos por ele.

Computada a pontuação final do candidato, atribui-se valor para cada questão correta, analisando a coerência entre desempenho individual e nível de dificuldade. Ou seja, é importante a consistência da competência do sujeito avaliado, por isso, o sistema matemático rejeita os acertos das questões com alto nível de dificuldade para aqueles que não pontuaram nas questões de baixo nível de dificuldade, interpretando que esses tenham sido acertos casuais, ou "chutes".

Como comentado, o ENEM, a partir de 2009, passou a ser utilizado como modalidade alternativa, de modo integral ou parcial, para seleção a vagas disponibilizadas por instituições de ensino superior que passaram a utilizá-lo como instrumento de seleção, balizando as tendências das reformas empresariais da década à medição da qualidade por via das avaliações em larga escala. Com a Portaria nº 109 de 2009, os seus resultados passaram a ser disponibilizados para os estabelecimentos de ensino e as organizações do mundo do 
trabalho interessadas em utilizá-los, desde que tenha autorização, por escrito, do participante especificamente para seleção ou classificação.

Entre os programas de acesso que utilizam atualmente a proficiência do ENEM como via de seleção, a partir de 2009, está o Sistema de Seleção Unificada (SISU). É um programa do Ministério da Educação que oferece vagas em universidades públicas de todo o Brasil. O SISU classifica os candidatos com base no desempenho que tiveram na edição mais recente do ENEM. Não há requisito de renda para participar, basta ter feito o ENEM mais recente e não ter zerado na redação. As inscrições são gratuitas e acontecem todo semestre, inicialmente eram pagas.

O Fundo de Financiamento Estudantil (FIES) é um programa do Ministério da Educação destinado a financiar a graduação na educação superior de estudantes matriculados em cursos superiores não gratuitas na forma da Lei 10.260/2001 e que também se articula com o ENEM. Podem recorrer ao financiamento os estudantes matriculados em cursos superiores que tenham avaliação positiva nos processos conduzidos pelo Ministério da Educação ${ }^{24}$.

Para participar é necessário comprovar renda familiar bruta mensal de no máximo 2,5 salários mínimos por pessoa e ter feito qualquer edição do ENEM a partir de 2010, com desempenho de pelo menos 450 pontos na média das provas e nota maior do que zero na redação.

Outro programa que, articulado ao ENEM, facilita o acesso a universidades privadas é o Programa Universidade para Todos (PROUNI), criado em 2004, que oferece bolsas de cobertura integral ou parcial para estudantes de baixa renda. O processo de seleção também utiliza o resultado de proficiência obtido na edição mais recente do ENEM como critério (com desempenho mínimo de 450 pontos na média das provas e nota maior do que zero na redação). Além disso, o candidato deverá ter cursado todo o ensino médio em escola pública, ou como bolsista integral em escola particular e obedecer aos critérios de renda familiar.

É necessário salientar que a democratização do ensino superior não corresponde somente ao acesso às universidades e não se traduz em um serviço social de distribuição de bolsas de estudos. A abertura indiscriminada de cursos e faculdades particulares é ponto preocupante quanto à qualidade do ensino ofertado aos estudantes de baixa renda, que almejam melhores oportunidades no mundo trabalho, e quanto às vantagens obtidas pela iniciativa privada e subsidiadas pelo Estado em relação à inadimplência. Assim, o ensino

\footnotetext{
${ }^{24}$ Portal do MEC. Disponível em: http://sisfiesportal.mec.gov.br. Consulta realizada em 10/11/2017.
} 
superior pode ser visto como um negócio atraente e seguro para o setor privado; no entanto corre o risco de assumir caráter circular de exclusão, onde uma camada desfavorecida de estudantes que antes não alcançava escolaridade superior, agora recebe formação profissional deficiente que a marginaliza novamente na disputa por postos de trabalho.

Segundo o discurso oficial, o ENEM contribuiu para a democratização das oportunidades de acesso às vagas oferecidas por Instituições Federais de Ensino Superior (IFES), favorecendo a mobilidade acadêmica e induzindo a reestruturação dos currículos do Ensino Médio. Entretanto, é preciso cuidado com tal leitura, pois, “o sucesso efetivo deste sistema depende da boa formulação das provas, apresentando questões consistentes com a avaliação das habilidades e competências preconizadas para o Ensino Médio, garantindo a mobilidade pretendida através da diversidade entre os ingressantes” (SILVEIRA; BARBOSA; SILVA, 2015, p. 1101-2).

Dentre as importantes mudanças no ENEM de 2009 até os dias atuais está a certificação referente à conclusão do Ensino Médio com base nos resultados do ENEM, que foi extinta em 2017, como pode ser observado na Portaria nº 468 de 03 de Abril de 2017 que revoga a Portaria No 807 de 18 de Junho de 2010.

A certificação destinava-se às pessoas que não concluíram o ensino médio na idade considerada própria, conforme o Art. 37 da Lei de Diretrizes e Bases da Educação de 1996. Ao solicitar a certificação do ensino médio com base no ENEM, o jovem ou o adulto encontrava oportunidades para o reconhecimento e validação dos conhecimentos e competências desde que atendesse as exigências de pontuação e idade. Desde 2017 os diplomas passaram a ser emitidos através da realização do Encceja, que já é aplicado como via de certificação do Ensino Fundamental.

Desde 2009 o ENEM era utilizado como alternativa para que adultos que não concluíram o ensino médio na idade adequada pudessem buscar o certificado através da proficiência exigida e demais critérios a fim de obter a chance de ingresso no ensino superior e participação em concursos, o que é forte fator de motivação para a realização do exame.

A portaria $n^{\circ}$ 342, de 28 de setembro de 2012 do INEP que estabelece sistemática para cálculo e divulgação da proficiência média dos participantes do ENEM através do Enem por escola, possibilitou que as escolas tivessem acesso às informações sobre o desempenho dos estudantes nas provas e dirigissem medidas de reforço a determinados conteúdos.

Com relação esse tipo de efeito, Juan Casassus (2009) aponta a possibilidade da redução dos currículos às áreas e tópicos abrangidos pela avaliação padronizada, pois os professores empenhariam um ensino preparatório para o ENEM, fazendo com que “os 
professores ocupem o tempo a exercitar os alunos a escolher uma resposta entre as apresentadas” (p. 75).

A divulgação dos dados em 2012 passou a informar apenas os dados das escolas que apresentam no mínimo 50\% de participação dos estudantes matriculados no ensino médio regular. A construção de rankings hierarquizantes, como se pretende discutir mais adiante, alimenta a publicidade em escolas privadas que passam a treinar professores e alunos rumo ao alcance de boas posições, também voltada ao ingresso de alunos em universidades públicas de prestígio. Sabe-se que a ampla divulgação de resultados por escola se fez responsável pela construção de hierarquia de suposta qualidade, que pouco contribuem para a compreensão dos resultados, pois tomam como base a nota dos alunos e não o valor atribuído à escola, ou seja, outras variáveis correlacionadas à escola são relevantes na composição do desempenho, para além do mérito.

É sabido que grandes colégios de Ensino Médio reúnem os melhores alunos em uma única turma e criando outro CNPJ. Na teoria, são empresas diferentes, mas, na prática, trata-se do mesmo colégio. Além disso, boa parte dos alunos dessas turmas especiais ingressa no colégio apenas no terceiro ano, ou seja, veio de outras escolas e recebe bolsas para se dedicar ao ENEM e elevar a pontuação do estabelecimento. Para enfrentar essa manobra, o INEP adicionou novos índices que podem ser observados, como o tamanho da escola, a permanência do aluno e a taxa de reprovação. Em resumo, é possível analisar se a escola mantém o aluno durante os três anos do Ensino Médio ou o transfere para unidade com outro CNPJ, no caso dos alunos com melhor performance (BESSA, 2016).

Assim, o ENEM por escola serve para informar a sociedade sobre a diferença de rendimento presente nas escolas participantes, e segundo Travitzki (2013, p. 212), “outro aspecto a ser destacado sobre o ranking do ENEM enquanto indicador de qualidade escolar diz respeito a quanto do desempenho dos alunos pode ser atribuído ao mérito da escola” Embora o ENEM avalie o mérito dos participantes informa de maneira insuficiente os fatores ligados ao efeito dos fatores intraescolares, o que recai sobre a sua insuficiência e inadequação para avaliar isoladamente a qualidade das escolas, tendo como limites a supervalorização de um único exame e os riscos de aumentar a desigualdade (TRAVITZKI, 2013).

Em 2017 foi abolida a divulgação do ENEM por Escola, e o INEP passou a disponibilizar o Boletim de Resultados da Escola que contém uma análise geral dos desempenhos, resguardando o sigilo e identidade dos participantes da prova e em conformidade com as exigências para acesso, que são: a) encaminhar solicitação formal ao 
INEP, b) o pagamento da quantia de cinco reais por aluno (rede privada); c) índice de participação no exame de $90 \%$ de alunos, e d) posse do número de inscrição no ENEM (BRASIL, 2002).

A polêmica em torno da suspensão da divulgação do ENEM por Escola localiza-se no fato que antes as escolas eram comparadas em situações de alunos com condições socioeconômicas distintas além do fato das escolas possuírem diferentes índices de participação no ENEM. Por se tratar de uma avaliação não obrigatória, escolas com baixa participação eram comparadas a escolas com maior índice, o que fatalmente influenciava nos resultados.

Mais recentemente, o INEP buscou qualificar essa análise, incentivando possíveis combinações através das variáveis de contexto a fim de apurar a análise das proficiências.

Por outro lado, questiona-se a livre interpretação dos dados oficiais públicos, a retenção de informações, a transparência das políticas educacionais públicas e a escolha de critérios para avaliar a qualidade.

Conhecer o desempenho é importante, entretanto é preciso considera as desigualdades socioeconômicas da população que realiza a prova, bem como os patamares de qualidade das escolas, já que uma perspectiva meramente quantitativa do desempenho pode de consolidação de estigmas, reforço da estratificação entre estabelecimentos de ensino e da desigualdade entre estudantes.

Nesse aspecto, os resultados divulgados pelo ENEM possibilitavam uma análise hierarquizante entre estabelecimentos de ensino, ainda que não tenha esse objetivo assumido pelo MEC. Além do que, a forma como os resultados da avaliação eram divulgados não considerava que a proficiência dos indivíduos tem uma forte relação com as características de contexto dos alunos, não levando em conta as condições de vida e trajetórias escolares, como já se discutiu neste trabalho.

Para Nogueira e Lacerda (2014, p.130), tratar os resultados de proficiência de forma mais equitativa "suporia debitar da nota do aluno aquilo que se deve ao seu background socioeconômico e que não pode, portanto, ser imputado à escola por ele frequentada”.

Casassus adverte sobre a estigmatização dos resultados de desempenho e sua sobreposição das condições sociais geradoras de escalonamento:

Os resultados das provas indicam-nos que no extremo dos "burros" e das baixas pontuações se encontram os pobres, e que os ricos se encontram no extremo dos “inteligentes” e com pontuações altas. (...) Um sistema meritocrático numa democracia formal, ou seja, uma democracia que não toma em consideração a desigualdade de condições e os contextos de pobreza, que nos diz que há uma razão 
de ser para os burros serem pobres: é porque são burros. Assumir isto é esquecer um ponto crucial: os efeitos negativos que a pobreza tem na aprendizagem e no desenvolvimento cognitivo dos alunos. (CASASSUS, 2009, p. 76).

A qualidade na educação, como dito anteriormente, pode ser uma via de equidade e justiça dada às crianças e adolescentes que vivem em extrema pobreza, em condições nunca consideráveis quando se refere ao esforço individual ou ao mérito. A esse respeito, Ravitch (2011, p. 255) pontua: “as crianças que cresceram na pobreza necessitam de recursos extras”, estes, tomados como investimento em qualidade na educação.

Portanto, os resultados do ENEM devem ser interpretados cuidadosamente, uma vez que a participação dos estudantes no exame é voluntária, o que significa que a representatividade dos resultados varia de acordo a participação de estudantes, não sendo, portanto, amostral.

Diante da heterogeneidade de contextos onde as escolas estão inseridas, torna-se necessário considerar o resultado do desempenho dos alunos associado aos diferentes fatores que caracterizam estes contextos. Qualquer comparação entre escolas pertencentes a contextos diferentes sem a devida ponderação entre o desempenho e os diferentes fatores intra e extraescolares a ele associados é considerada indevida (INEP, 2016). Isso não impede, contudo, a ampla divulgação desses resultados pela mídia e nas propagandas das escolas particulares.

Os indicadores disponibilizados pelo $\operatorname{INEP}^{25}$ são: a) socioeconômico, que possibilita, de modo geral, situar o público atendido pela escola em um estrato social, apontando o padrão de vida referente a cada um de seus níveis ou estratos. Esse indicador é calculado a partir do nível de escolaridade dos pais e da posse de bens e contratação de serviços pela família dos alunos; b) indicador de adequação da formação docente, que analisa a formação dos docentes que lecionam no ensino médio na escola. Apresenta o percentual de disciplinas que são ministradas por professores com formação superior de Licenciatura; c) de tempo de permanência na escola, indicando os participantes que cursaram todo o ensino médio na mesma escola; d) correspondem às taxas de aprovação, reprovação e abandono baseadas em informações sobre o movimento e rendimento escolar dos alunos, registrados no Censo Escolar da Educação Básica.

Entre os indicadores, é importante destacar dois: o nível socioeconômico (INSE) e a formação docente. O INSE é a média do nível socioeconômico dos estudantes, distribuído em

\footnotetext{
${ }^{25}$ Informações sobre os indicadores são apresentadas em Nota Técnica específica disponível no endereço: http://portal.inep.gov.br/web/enem/enem-por-escola. Acesso em: 01/10/2015.
} 
sete níveis. O cálculo parte das informações dadas pelos estudantes no questionário contextual. Por meio desse indicador, é possível observar como o contexto social dos estudantes tem impacto direto sobre o desempenho escolar. Os dados mostram que quanto mais alto o nível socioeconômico, melhores são as notas em todas as áreas de conhecimento avaliadas, segundo o $\mathrm{MEC}^{26}$, tema que será mais discutido no próximo capítulo, a partir da análise dos resultados de Ribeirão Preto.

${ }^{26}$ Consta no Portal do MEC. Disponível em: http://portal.mec.gov.br/component/tags/tag/36409. Acesso em: 28/08/2017. 


\section{RESULTADOS}

Os dados aqui analisados foram coletados a partir dos Microdados do ENEM 2015 e compilados em gráficos e tabelas que reúnem, primeiramente, as informações de perfis dos participantes da edição de 2015 em Ribeirão Preto.

Mais adiante, serão apresentadas as médias de desempenho e discutida a associação dos fatores circunstanciais e de origem a estas proficiências, no sentido de esboçar os dois contrastantes arquétipos de participantes do exame: o aluno da escola pública e o aluno da escola privada.

Pretendeu-se tomar como apoio alguns conceitos da teoria social de grande amplitude no que concerne à complexificação das análises de contexto socioeconômico quando desvelado o desempenho nas avaliações em larga escala. Vale ressaltar que se buscou contribuir com a compreensão dos dados de proficiência à luz dos dados de contexto e não ater-se aos meros resultados de desempenho como ocorre nos discursos da mídia e do setor privado de ensino, sem evidentemente ter a pretensão de esgotá-los.

\subsection{OS PERFIS DOS PARTICIPANTES DO ENEM 2015 EM RIBEIRÃO PRETO A PARTIR DOS FATORES CIRCUNSTANCIAIS}

A Tabela 1 traz dados contidos nos Microdados do ENEM 2015 coletados através dos questionários preenchidos pelo inscritos no exame. Dispõe sobre a média de idade dos participantes do ENEM 2015 provenientes das redes pública (estadual) e privada de Ribeirão Preto, onde se pode observar idade adequada em ambas as redes, ao se considerar que o exame é aplicado ao término do ensino médio, e também um processo de juvenilização da rede pública.

A tabela a seguir informa a idade media dos participantes do ENEM 2015 na cidade de Ribeirão Preto por dependência administrativa. 
TABELA 1 - MÉDIA DE IDADE DOS PARTICIPANTES DO ENEM 2015 EM RIBEIRÃO PRETO POR DEPENDÊNCIA ADMINISTRATIVA

\begin{tabular}{c|c}
\hline $\begin{array}{c}\text { Dependência } \\
\text { Administrativa }\end{array}$ & Média de idade \\
\hline Pública & 17,4 \\
\hline Privada & 17,4 \\
\hline FONTE: INEP/MICRODADOS ENEM 2015
\end{tabular}

A idade média dos participantes que realizaram o exame é de 17,4 anos, o que comprova que o público inscrito na edição de 2015 em Ribeirão Preto é egresso do Ensino Médio ou em fase de conclusão, matriculado nas redes de educação, e indica conclusão na idade esperada para esta etapa nas redes de ensino pública e privada. Indica também que os estudantes mais velhos não optam pela inscrição no ENEM.

Outra relevante variável que compõe o perfil do estudante participante do ENEM é o gênero declarado. O Gráfico 1 revela o percentual do total participantes do ENEM 2015 divididos por gênero declarado, tipificado em feminino e masculino.

\section{GRÁFICO 1 - PERCENTUAL DE PARTICIPANTES DO ENEM 2015 EM RIBEIRÃO PRETO POR GÊNERO DECLARADO}

\section{Percentual de participantes por gênero declarado}

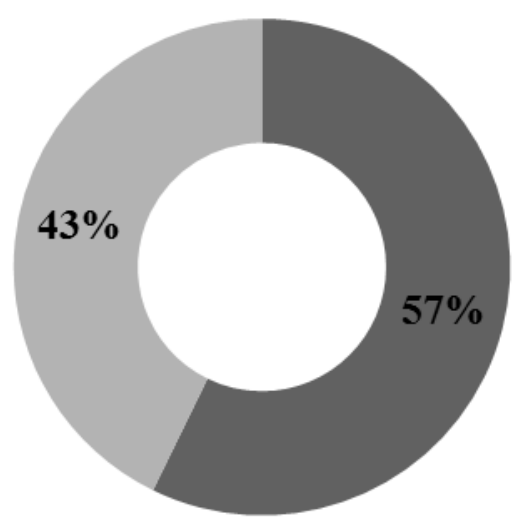

- Feminino

Masculino

FONTE: INEP/MICRODADOS ENEM 2015 
Conforme os estudos sobre gênero e educação do século XX, a educação nacional vem assistindo uma inversão nas desigualdades de gênero, sobretudo nas etapas finais da educação básica (FERRARO, 2010). Tal predominância do sexo feminino esteve presente também na composição de inscritos e participantes nas últimas edições (INEP, 2015).

Nota-se a superioridade do número de mulheres participantes do exame em quatorze pontos percentuais, dado ao avanço na escolaridade da mulher em nosso sistema escolar, o que faz possível supor o aumento do número de mulheres no ingresso ao ensino superior.

A Tabela 2 demonstra o número e percentual dos participantes do ENEM 2015 em Ribeirão Preto, distribuídos por gênero declarado e dependência administrativa.

TABELA 2 - PERCENTUAL DE PARTICIPANTES DO ENEM 2015 EM RIBEIRÃO PRETO POR DEPENDÊNCIA ADMINISTRATIVA, SEGUNDO GÊNERO

\begin{tabular}{c|c|c|c}
\hline $\begin{array}{c}\text { Dependência } \\
\text { Administrativa }\end{array}$ & $\begin{array}{c}\text { Gênero } \\
\text { declarado }\end{array}$ & (n) & \% \\
\hline \multirow{2}{*}{ Pública } & Feminino & 1.599 & $58,8 \%$ \\
\cline { 2 - 4 } & Masculino & 1.119 & $41,2 \%$ \\
\hline \multirow{2}{*}{ Privada } & Feminino & 1.101 & $55,1 \%$ \\
\cline { 2 - 4 } & Masculino & 899 & $45,0 \%$ \\
\hline
\end{tabular}

FONTE: INEP/MICRODADOS ENEM 2015

É pequena a diferença entre as redes, no entanto é perceptível o avanço na escolarização das mulheres na escola pública e à diminuição relativa de participantes do gênero masculino, por razões prováveis que afetam diretamente a permanência na escola que não serão aprofundadas neste trabalho, como a violência e maior mortalidade entre os jovens do sexo masculino.

As recentes edições do ENEM confirmam uma tendência histórica em relação à distribuição por raça/cor dos inscritos que evidencia a grande desigualdade de acesso às oportunidades escolares entre brancos e negros.

A Tabela 3 revela a quantidade e percentual de participantes do ENEM de 2015 por raça/cor declarada ${ }^{27}$ e dependência administrativa em Ribeirão Preto. Lembrando que o questionário do ENEM obedece a critérios do IBGE que adota como estratos de raça/cor branca, preta, parda, amarela e indígena.

Na tabela a seguir foram aglutinados os estratos de cor/raça branca e amarela, e também parda e preta.

\footnotetext{
${ }^{27}$ Trata-se da autoclassificação determinada pelo próprio respondente.
} 
TABELA 3 - QUANTIDADE E PERCENTUAL DE PARTICIPANTES DO ENEM 2015 EM RIBEIRÃO PRETO POR DEPENDÊNCIA ADMINISTRATIVA, SEGUNDO RAÇA/COR DECLARADA

\begin{tabular}{c|c|c|c|c|c|c}
\hline \multirow{2}{*}{$\begin{array}{c}\text { Cor/raça } \\
\text { declarada }\end{array}$} & \multicolumn{2}{|c|}{ Pública } & \multicolumn{2}{c|}{ Privada } & \multicolumn{2}{c}{ Total } \\
\cline { 2 - 7 } & (n) & $(\%)$ & (n) & (\%) & (n) & $(\%)$ \\
\hline $\begin{array}{c}\text { Não declarado } \\
\text { Branca e } \\
\text { amarelo }\end{array}$ & 20 & $0,7 \%$ & 20 & $0,9 \%$ & 40 & $0,8 \%$ \\
$\begin{array}{c}\text { Preta e Parda } \\
\text { Indígena }\end{array}$ & 1582 & $58,3 \%$ & 1752 & $87,7 \%$ & 3334 & $70,7 \%$ \\
$\begin{array}{c}\text { Não dispõe da } \\
\text { informação }\end{array}$ & 11 & $0,4 \%$ & 1 & $09 \%$ & 12 & $0,3 \%$ \\
\hline
\end{tabular}

FONTE: INEP/MICRODADOS ENEM 2015

Considerando essas categorias, a diferença na distribuição racial entre a rede pública e privada se dá a partir do percentual de participantes da raça branca ou amarela matriculados em escola pública de Ribeirão Preto na edição de 2015, que representa 58,3\% enquanto na rede privada, 87,7\%. É preciso, além de reiterar a reprodução da desigualdade econômica e aspectos históricos inerentes aos direitos sociais da população negra, podendo considerar hipoteticamente que entre os $11,2 \%$ de alunos negros matriculados na rede privada, existiriam jovens que advém do grupo de sujeitos “premiados” pelo mérito que obtêm bolsas de estudos.

Como se verá mais à frente, o desempenho dos estudantes está muito relacionado com as trajetórias escolares dos pais. Sendo assim, e de acordo com pesquisas em sociologia da educação é fundamental que se conheça a escolaridade dos pais. Os estudos da área em geral usam as escolaridades das mães com um proxy adequado para esse indicador.

A Tabela 4 traz o percentual de participantes por escolaridade da mãe, dividida em estratos de continuidade dos estudos e dependência administrativa, o que coopera na definição de um perfil de aluno por tipo de escola. 
TABELA 4 - PERCENTUAL DE PARTICIPANTES NO ENEM 2015 EM RIBEIRÃO PRETO POR ESCOLARIDADE DA MÃE, SEGUNDO DEPENDÊNCIA ADMINISTRATIVA

\begin{tabular}{|c|c|c|}
\hline Escolaridade da mãe ${ }^{28}$ & Pública & Privada \\
\hline Nunca estudou. & $0,6 \%$ & $0,1 \%$ \\
\hline Não completou a $4^{a}$ série $/ 5^{\circ}$ ano do Ensino Fundamental. & $8,7 \%$ & $0,7 \%$ \\
\hline $\begin{array}{l}\text { Completou a } 4^{\mathrm{a}} \text { série } / 5^{\circ} \text { ano, mas não completou a } 8^{\mathrm{a}} \text { série } / 9^{\circ} \text { ano do } \\
\text { Ensino Fundamental. }\end{array}$ & $16,1 \%$ & $2,0 \%$ \\
\hline $\begin{array}{l}\text { Completou a } 8^{\mathrm{a}} \text { série } / 9^{\circ} \text { ano do Ensino Fundamental, mas não completou } \\
\text { o Ensino Médio. }\end{array}$ & $23,6 \%$ & $6,6 \%$ \\
\hline Completou o Ensino Médio, mas não completou a Faculdade. & $40,0 \%$ & $34,6 \%$ \\
\hline Completou a Faculdade, mas não completou a Pós-graduação. & $6,2 \%$ & $35,1 \%$ \\
\hline Completou a Pós-graduação. & $1,8 \%$ & $20,1 \%$ \\
\hline Não sabe. & $3,1 \%$ & $1,0 \%$ \\
\hline
\end{tabular}

FONTE: INEP/MICRODADOS ENEM 2015

Ao defrontarmos as faixas percentuais por rede de ensino é possível perceber que a conclusão do Ensino Médio é o único nível de aproximação, onde 40\% das mães da escola pública e 34,6\% das mães da rede privada.

Das disparidades, merecem destaque o dado correspondente ao nível Ensino Superior, aonde apenas 6,2\% das mães dos alunos da rede pública concluíram essa etapa. Por outro lado, 25,4 \% das mães dos alunos inscritos da rede pública possuem até o ensino fundamental incompleto; nos alunos oriundos da rede privada esse percentual é de apenas $2,8 \%$.

Além da escolaridade é fundamental analisar também as ocupações exercidas pelos pais.

O modelo utilitarista de Coleman atribui à escolarização um viés central na organicidade de uma sociedade democrática onde o ensino é via de igualdade de oportunidades. Já o enfoque estruturalista da obra de Pierre Bourdieu, critica a economia política clássica pelo fato de o capital econômico ser conversível em direitos de propriedade e dinheiro, que faz a mobilidade social refém da troca mercantil, onde os agentes econômicos procuram a maximização de seus interesses (SALEJ, 2005).

As Tabelas 5 e 6 apresentam o percentual de participantes do ENEM 2015 discriminados pelas modalidades de ocupação da mãe nas redes pública e privada de Ribeirão Preto. A seguir as ocupações são classificadas por grupos, indo do grupo 1, com ocupações de

\footnotetext{
${ }^{28}$ A pergunta do questionário socioeconômico considera a mãe ou mulher responsável pela pessoa inscrita no exame.
} 
baixa qualificação e status social, até o grupo 5 que engloba as ocupações de maior escolaridade, remuneração e prestígio social.

Ocupações por grupos:

- Grupo 1: Lavrador(a), agricultor(a) sem empregados, boia fria, criador(a) de animais (gado, porcos, galinhas, ovelhas, cavalos etc.), apicultor(a), pescador(a), lenhador(a), seringueiro(a), extrativista.

- Grupo 2: Diarista, empregado(a) doméstico(a), cuidador(a) de idosos, babá, cozinheiro(a) (em casas particulares), motorista particular, jardineiro(a), faxineiro(a) de empresas e prédios, vigilante, porteiro(a), carteiro(a), officeboy, vendedor(a), caixa, atendente de loja, auxiliar administrativo(a), recepcionista, servente de pedreiro, repositora de mercadoria.

- Grupo 3: Padeiro(a), cozinheiro(a) industrial ou em restaurantes, sapateiro(a), costureiro(a), joalheiro(a), torneiro(a) mecânico(a), operador(a) de máquinas, soldador(a), operário(a) de fábrica, trabalhador(a) da mineração, pedreiro(a), pintor(a), eletricista, encanador(a), motorista, caminhoneiro(a), taxista.

- Grupo 4: Professor(a) (de ensino fundamental ou médio, idioma, música, artes etc.), técnico(a) (de enfermagem, contabilidade, eletrônica etc.), policial, militar de baixa patente (soldado, cabo, sargento), corretor(a) de imóveis, supervisor(a), gerente, mestre de obras, pastor(a), microempresário(a) (proprietário(a) de empresa com menos de 10 empregados), pequeno(a) comerciante, pequeno(a) proprietário(a) de terras, trabalhador(a) autônomo(a) ou por conta própria.

- Grupo 5: Médico(a), engenheiro(a), dentista, psicólogo(a), economista, advogado(a), juiz(a), promotor(a), defensor(a), delegado(a), tenente, capitão(ã), coronel, professor(a) universitário(a), diretor(a) em empresas públicas e privadas, político(a), proprietário(a) de empresas com mais de 10 empregados. 
TABELA 5 - PERCENTUAL DE PARTICIPANTES DO ENEM 2015 EM RIBEIRÃO PRETO POR DEPENDÊNCIA ADMINISTRATIVA, SEGUNDO A OCUPAÇÃO DA MÃE

\begin{tabular}{c|c|c}
\hline $\begin{array}{c}\text { Ocupação da } \\
\text { Mãe }\end{array}$ & $\begin{array}{c}\text { Pública } \\
\text { (n=2718) }\end{array}$ & $\begin{array}{c}\text { Privada } \\
\text { (n=2000) }\end{array}$ \\
\hline Grupo 1 & $1,7 \%$ & $0,5 \%$ \\
\hline Grupo 2 & $55,9 \%$ & $16,4 \%$ \\
\hline Grupo 3 & $12,0 \%$ & $4,0 \%$ \\
\hline Grupo 4 & $18,0 \%$ & $44,9 \%$ \\
\hline Grupo 5 & $1,2 \%$ & $23,4 \%$ \\
\hline Não sabe & $11,1 \%$ & $11,0 \%$ \\
\hline
\end{tabular}

FONTE: INEP/MICRODADOS ENEM 2015

O capital econômico confirma sua relevante incidência e caráter determinante nos perfis dos estudantes e às escolas. O dualismo entre os sistemas de ensino público e privado faz compreender que a composição da renda familiar está no cerne das desigualdades, conforme revelam as informações contexto da tabela.

A região de Ribeirão no passado foi consagrada como a Capital do Café e na atualidade ganha destaque no cenário do agronegócio que reflete crescimento em vários setores da economia. Embora a dinâmica da economia agroindustrial não permeie todos os segmentos da sociedade, tem grande impacto na oferta de empregos e salários do ramo comercial e de serviços.

O dado que melhor equipara a ocupação da mãe de participantes das redes estadual e privada, ainda que pouco expressivo (1,7\% da rede estadual e $0,5 \%$ da rede pública), diz respeito ao Grupo 1, que representa possivelmente trabalhadores ligados à agricultura familiar, por vezes suprimida pela mecanização do setor agrícola.

O Grupo 2 revela grande distância no percentual de mães subassalariadas, sendo na rede estadual de $55,9 \%$ ante $16,4 \%$ na rede privada.

O Grupo 3 que engloba trabalhadoras autônomas e prestadores de serviços é presente também em superioridade da rede estadual, com $12 \%$ enquanto na rede privada alcança apenas $4 \%$.

O grupos 4 e 5 apontam a inversão percentual gradual com a diminuição de mães da rede pública ocupando melhores posições na hierarquia salarial dada sua formação insuficiente, sobretudo por não alcançarem formação no ensino superior. Impressiona o fato do índice de mães da rede privada incluídas no grupo 5 ser quase vinte vezes maior do que 
aquele apresentado pelas mães cujos inscritos vieram da rede pública. É uma mostra cabal da desigualdade no acesso à educação no Brasil. A escola pública é a escola dos pobres e remediados e isso, como se verá mais adiante, refletirá nos indicadores de desempenho de seus estudantes.

Para melhor compreensão dos patamares salariais das famílias dos participantes do ENEM 2015 de Ribeirão Preto que serão apresentados adiante, a Tabela 6 informa os percentuais das ocupações dos pais dos participantes segundo o tipo de escola.

TABELA 6 - PERCENTUAL DE PARTICIPANTES DO ENEM 2015 EM RIBEIRÃO PRETO POR DEPENDÊNCIA ADMINISTRATIVA, SEGUNDO A OCUPAÇÃO DO PAI

\begin{tabular}{c|c|c}
\hline Ocupação do pai & $\begin{array}{c}\text { Pública } \\
(\mathbf{N = 2 7 1 8})\end{array}$ & $\begin{array}{c}\text { Privada } \\
(\mathbf{N}=\mathbf{2 0 0 0})\end{array}$ \\
\hline Grupo 1 & $2,5 \%$ & $1,4 \%$ \\
\hline Grupo 2 & $25,3 \%$ & $6,8 \%$ \\
\hline Grupo 3 & $35,7 \%$ & $11,3 \%$ \\
\hline Grupo 4 & $20,5 \%$ & $40,3 \%$ \\
\hline Grupo 5 & $2,6 \%$ & $33,9 \%$ \\
\hline Não sabe & $13,4 \%$ & $6,3 \%$ \\
\hline FONTE: INEP/MICRODADOS ENEM 2015
\end{tabular}

Mesmo seguindo a mesma perspectiva de diferenciação econômica presente nas famílias das redes estadual e privada, a Tabela 6 revela percentuais de desigualdade entre as ocupações dos pais ainda gigantescos, mas um pouco menores do que ocorre com as mães.

Os pais, segundo os padrões patriarcais possuem menos atribuições domésticas e mais possibilidades de se dedicar à sua formação e carreira. Isto se dá em razão da ainda intransponível barreira da desigualdade de gênero muito presente na questão salarial e formação acadêmica, como é possível observar nos percentuais de mães e pais dos participantes da rede privada quanto à sua ocupação inserida no Grupo 5: pais, 33,9\% e mães, 23,4\%. Cabe comentar também que a melhoria do acesso à educação por parte das mulheres é conquista recente.

A Tabela 7 mensura o percentual aproximado de pessoas que vivem na mesma residência dos participantes do ENEM nas redes de ensino de Ribeirão Preto no ano de 2015. 
TABELA 7 - PERCENTUAL DE PARTICIPANTES DO ENEM 2015 EM RIBEIRÃO PRETO POR NÚMERO DE PESSOAS RESIDENTES, SEGUNDO DEPENDÊNCIA ADMINISTRATIVA

\begin{tabular}{l|l|l}
\hline $\begin{array}{c}\text { Dependência } \\
\text { Administrativa }\end{array}$ & $\begin{array}{c}\text { Até quatro } \\
\text { pessoas }\end{array}$ & $\begin{array}{c}\text { Cinco ou } \\
\text { mais } \\
\text { pessoas }\end{array}$ \\
\hline Pública & $67 \%$ & $33 \%$ \\
\hline Privada & $81 \%$ & $19 \%$ \\
\hline
\end{tabular}

FONTE: INEP/MICRODADOS ENEM 2015

A tabela 7 reforça a maneira de como as famílias com melhores condições de vida, que caracterizam o público da escola privada, têm acesso ao planejamento familiar, quando 81\% declararam que vivem em um núcleo de até 4 pessoas, diante de $67 \%$ dos participantes alunos de escolas estaduais de Ribeirão Preto.

O Gráfico 2 revela o percentual de participantes do ENEM na edição de 2015 na cidade de Ribeirão Preto por faixa de renda mensal familiar e tipo de escola.

É necessário sublinhar que para este trabalho optou-se por agregar as diferentes faixas de renda do questionário do exame $\mathrm{e}^{29} \mathrm{em}$ dois grandes estratos.

${ }^{29}$ Estratos de renda discriminados no questionário do ENEM 2015 disponíveis para escolha dos inscritos: Nenhuma renda; até R\$ 788,00; de R\$ 788,01 até R\$ 1.182,00; de R\$1.182,01 até R\$ 1.572,00; de R\$ $1.572,01$ até $\mathrm{R} \$ 1.970,00$; de $\mathrm{R} \$ 1.970,01$ até $\mathrm{R} \$ 2.364,00$; de $\mathrm{R} \$ 2.364,01$ até $\mathrm{R} \$ 3.152,00$; e $\mathrm{R} \$ 3.152,01$ até $\mathrm{R} \$ 3.940,00$; de $\mathrm{R} \$ 3.940,01$ até $\mathrm{R} \$ 4.728,00$; de $\mathrm{R} \$ 4.728,01$ até $\mathrm{R} \$ 5.516,00$; de $\mathrm{R} \$ 5.516,01$ até $\mathrm{R} \$$ 6.304,00; de $\mathrm{R} \$ 6.304,01$ até $\mathrm{R} \$ 7.092,00$; de $\mathrm{R} \$ 7.092,01$ até $\mathrm{R} \$ 7.880,00$; de $\mathrm{R} \$ 7.880,01$ até $\mathrm{R} \$ 9.456,00$; de $\mathrm{R} \$ 9.456,01$ até $\mathrm{R} \$ 11.820,00$; de $\mathrm{R} \$ 11.820,01$ até $\mathrm{R} \$ 15.760,00$, e mais de 15.760,00. 


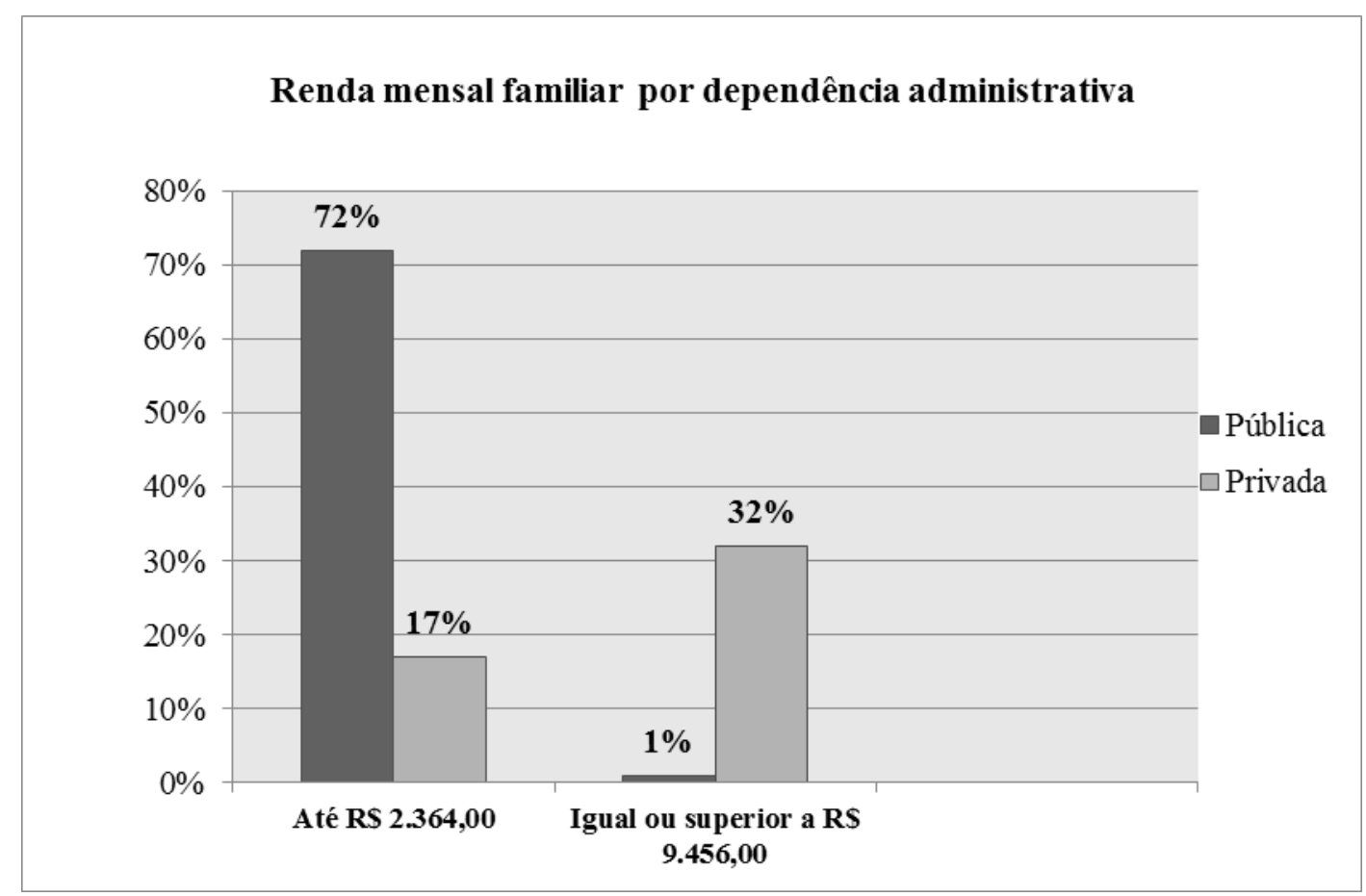

FONTE: INEP/MICRODADOS ENEM 2015

Obs: a Soma é inferior a $100 \%$, pois optou-se por selecionar as faixas de renda extremas

Um fator que sintetiza as análises sobre a desigualdade social, basilar da desigualdade educacional, é a distribuição da renda entre as famílias das escolas consideradas boas e das escolas ruins, que na verdade são escolas para ricos e escolas para pobres.

Os 72\% dos participantes do ENEM matriculados em escolas estaduais confirmaram renda mensal de até $\mathrm{R} \$ 2.364,00$, enquanto apenas 1\% deste público declarara média de renda mensal superior à R\$ 9.456,00. Dados muito condizentes com a iniquidade na distribuição de renda e riquezas no Brasil, onde a expressiva maioria das famílias detém o menor rendimento financeiro.

Cabe acrescentar diante desta realidade, que as classes sociais distinguem-se, sobretudo pela posse das propriedades materiais e pelas representações que são produzidas em estilos de vida. Logo,

Esses dois modos de existência não são independentes, ainda que as representações tenham certa autonomia em relação às distribuições: a representação que os agentes se fazem de sua posição no espaço social [...] é o produto de um sistema de esquemas de percepção e de apreciação (habitus) que é ele mesmo o produto incorporado de uma condição definida por uma posição determinada quanto à 
distribuição de propriedades materiais (objetividade 1) e do capital simbólico (objetividade2) e que leva em conta não somente as representações (que obedecem às mesmas leis) que os outros têm dessa mesma posição e cuja agregação define o capital simbólico (comumente designado como prestígio, autoridade, etc.), mas também a posição nas distribuições retraduzidas simbolicamente no estilo de vida (BOURDIEU, p. 111, 2013).

Os elementos analisados no Gráfico 3 incitam um esforço de aproximação do conceito de capital simbólico, aqui alusivo ao prestígio que dirige ao status à presença e frequência de empregada doméstica na residência da família. Status regido por condições e características individuais como raça, renda e reconhecimento profissional.

\section{GRÁFICO 3 - PERCENTUAL DE PARTICIPANTES DO ENEM 2015 EM RIBEIRÃO PRETO QUE DECLARARAM PRESENÇA/FREQUÊNCIA DE EMPREGADA(O) DOMÉSTICA(O) EM RESIDÊNCIA, SEGUNDO DEPENDÊNCIA ADMINISTRATIVA}

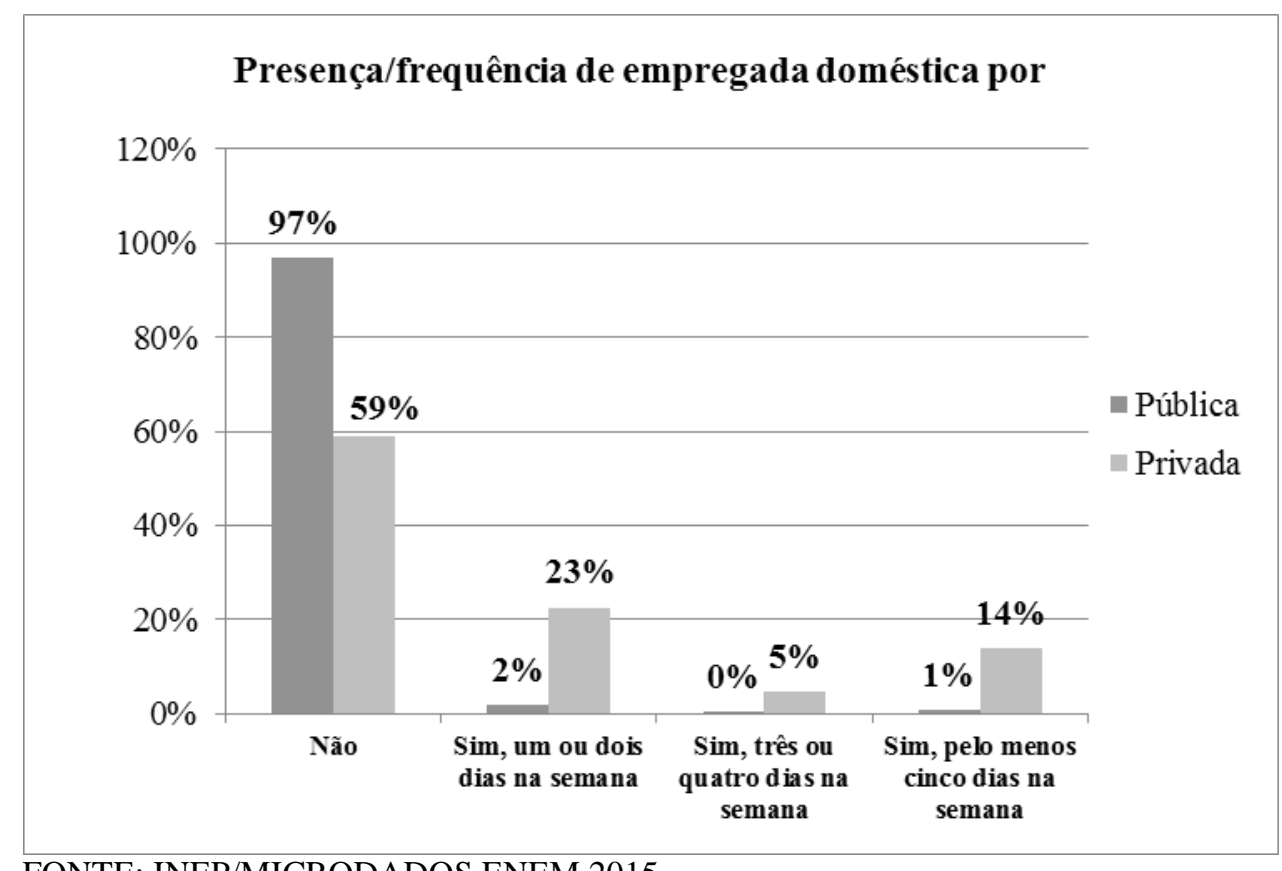

FONTE: INEP/MICRODADOS ENEM 2015

Dos respondentes da escola pública que participaram do ENEM 2015 em Ribeirão Preto, 97\% declararam não contarem com a presença de empregada doméstica. Da escola privada, 59\% afirmaram que não contam com os serviços de empregada doméstica.

Em seguida, o percentual mais elevado de respondentes da rede privada é de 23\% dos participantes que alegaram a presença de empregado(a) doméstico(a) uma ou duas vezes na semana sua residência. Apenas 14\% dos respondentes da rede privada afirmaram que em sua residência trabalham empregadas domésticas ao menos cinco dias na semana. 
Os dados do Gráfico 3 inferem supor relativa deselitização das escolas particulares, ao passo que a regulamentação dos direitos das domésticas ressignifica as condições do exercício da profissão bem como obrigações tributárias e previdenciárias. Comum no passado, a presença de empregadas domésticas mensalistas nos domicílios de classe média tende a cair, seguindo uma tendência já comum nos países mais ricos, na razão direta da conquista de direitos por parte dessa categoria profissional.

A apropriação de bens e capitais infere no processo de aquisição e acesso aos conhecimentos valorizados no ENEM, segundo suas matrizes e compromissos com a etapa da educação avaliada. O exame, de algum modo, espera que o aluno tenha acesso aos meios de informação e tecnologias que certifiquem suas chances no mercado de trabalho.

A ideia de competência no contexto da escola advém dos conceitos de qualidade do mundo do trabalho, e segundo Perrenoud (1999), a escola toma esta ideia como pretexto de modernizar-se a fim de introduzir valores da economia de mercado na gestão escolar promovendo uma corrida por aquilo que nessa lógica entende-se por qualidade.

Em contribuição, o Gráfico 4 informa o percentual de participantes que possuem acesso à internet por dependência administrativa.

GRÁFICO 4 - PERCENTUAL DE PARTICIPANTES NO ENEM 2015 EM RIBEIRÃO PRETO QUE POSSUEM ACESSO À INTERNET, SEGUNDO A DEPENDÊNCIA ADMINISTRATIVA

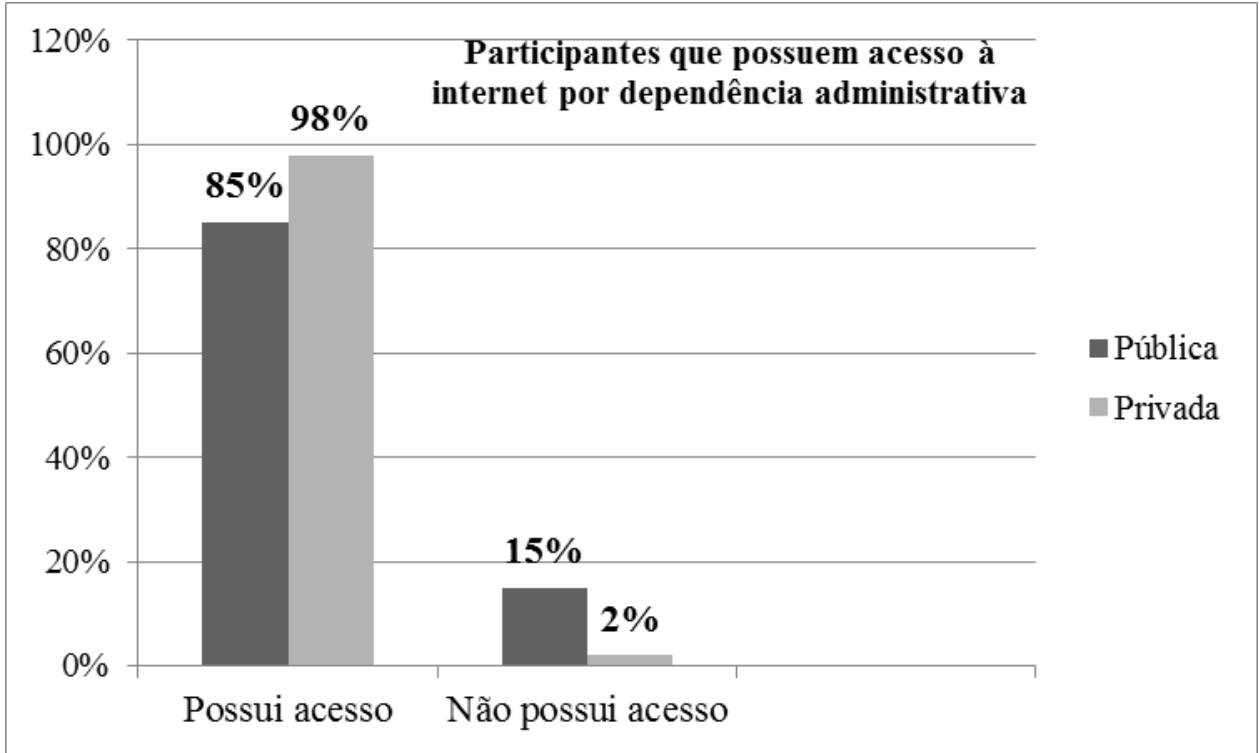

FONTE: INEP/MICRODADOS ENEM 2015 
Dos participantes que possuem acesso à internet, 98\% são da escola privada e 85\% da rede pública estadual. Apenas 2\% dos participantes do ensino privado não possuem acesso à internet, enquanto 15\% dos respondentes da escola pública declaram não terem acesso.

Considerando, a chamada “democratização” do acesso às tecnologias de telefonia móvel e popularização dos smartphones, compreende-se que esse contingente que declara não possuir acesso à web pertence às classes sociais fronteiriças à linha de pobreza e de menor poder de compra.

Para ter posse dos bens econômicos materiais é necessário ter simplesmente capital econômico, o que se evidencia na compra de livros, por exemplo. Todavia, para apropriar-se simbolicamente destes bens é necessário possuir os instrumentos desta apropriação, ou seja, é necessário possuir capital cultural no estado incorporado (CAZELLI, 2005).

As circunstâncias de vida reverberam sobre o sucesso e fracasso escolar, a permanência e a qualidade da aprendizagem. Nesse sentido, o ingresso no mundo do trabalho é fator expressivo das desigualdades educacionais e das diferenças entre os perfis dos públicos da escola pública e privada.

A Tabela 8 apresenta o percentual de alunos participantes pela ocorrência de experiência de labor de acordo com a dependência administrativa.

TABELA 8 - PERCENTUAL DE PARTICIPANTES DO ENEM 2015 EM RIBEIRÃO PRETO POR SUA EXPERÊNCIA LABORAL, SEGUNDO A DEPENDÊNCIA ADMINISTRATIVA

\begin{tabular}{lcc}
\hline & Pública & Privada \\
\hline Não, nunca trabalhei. & $49,8 \%$ & $88,6 \%$ \\
Sim, já trabalhei, mas não estou trabalhando. & $20,0 \%$ & $7,0 \%$ \\
Sim, estou trabalhando. & $30,2 \%$ & $4,5 \%$ \\
\hline
\end{tabular}

FONTE: INEP/MICRODADOS ENEM 2015

O exercício de atividade remunerada concomitante à vida acadêmica é movido pela necessidade de complementação da renda familiar e conforme o observado no Gráfico 2, mais de 70\% declararam como faixa de renda familiar mensal aproximadamente 2,5 salários mínimos, por conseguinte, 88,6\% dos alunos participantes do ENEM 2015 em Ribeirão Preto da rede privada afirmaram nunca terem trabalhado, enquanto 50,2\% dos participantes da rede pública disseram já ter iniciado vida no mercado de trabalho, destes 20\% declararam não estar mais trabalhando e 30,2\% estarem trabalhando no período de aplicação do exame. Tem-se aqui um dado objetivo que mostra claramente como são injustos os mecanismos de ingresso 
ao ensino superior, como o vestibular, pois além da já discutida influência do capital cultural, as condições de estudo são claramente piores para os estudantes que precisam trabalhar enquanto estudam no ensino médio. Sem dizer que, em geral, são trabalhos de baixa qualificação. Lembrando, por fim, que os dados referem-se aos estudantes que prestaram o Enem, o que, no caso da escola pública, significa apenas uma parcela dos estudantes matriculados no ensino médio.

A Tabela 9 exibe a distribuição percentual de participantes do exame de acordo com a idade em que iniciaram atividade remunerada por tipo de dependência administrativa.

\section{TABELA 9 - PERCENTUAL DE PARTICIPANTES DO ENEM 2015 EM RIBEIRÃO PRETO POR IDADE DE INÍCIO DE ATIVIDADE REMUNERADA, SEGUNDO A DEPENDÊNCIA ADMINISTRATIVA}

\begin{tabular}{l|l|l|l|l}
\hline $\begin{array}{l}\text { Idade em que começou } \\
\text { a trabalhar }\end{array}$ & Pública(n) & Pública\% & Privada (n) & Privada \% \\
\hline Nunca trabalhou. & 1.353 & $49,8 \%$ & 1.771 & $88,6 \%$ \\
\hline Menos de 14 anos. & 124 & $4,6 \%$ & 25 & $1,3 \%$ \\
\hline 15 anos. & 460 & $16,9 \%$ & 53 & $2,7 \%$ \\
\hline 16 anos. & 600 & $22,1 \%$ & 112 & $5,6 \%$ \\
\hline 17 anos. & 149 & $5,5 \%$ & 34 & $1,7 \%$ \\
\hline 18 anos. & 28 & $1,0 \%$ & 5 & $0,3 \%$ \\
\hline 19 anos. & 3 & $0,1 \%$ & - & - \\
\hline 20 anos. & 1 & $0,0 \%$ & - & - \\
\hline
\end{tabular}

FONTE: INEP/MICRODADOS ENEM 2015

Dos alunos da rede pública estadual de Ribeirão Preto que fizeram a prova do ENEM em 2015, 39\% iniciaram atividade remunerada entre 15 e 16 anos de idade, e na mesma faixa etária, 8,3\% dos participantes da rede privada deram início à vida laboral renumerada.

O artigo 60 do Estatuto da Criança e Adolescente (Lei ${ }^{\circ}$ 8.069/90) proíbe qualquer trabalho para menores de quatorze anos de idade, salvo na condição de aprendiz; e o artigo 65 determina que ao adolescente aprendiz, maior de quatorze anos, são assegurados os direitos trabalhistas e previdenciários. 
Segundo a OIT ${ }^{30}$, a realidade da empregabilidade dos jovens brasileiros encontra barreiras como a baixa remuneração, alto índice de rotatividade, precarização da relação de trabalho e dificuldade de conciliação entre estudos.

Aproximadamente um quarto dos jovens brasileiros não estuda nem trabalha. Grande parte desse grupo é composta por mulheres, principalmente negras e pardas, que assumem as responsabilidades familiares cotidianas, o que tornam difícil a conciliação de trabalho e vida escolar $^{31}$.

Perante os dados da Tabela 9 é muito presumível que o aluno da escola pública que se encontra entre os 39\% que começaram a trabalhar entre 15 e 16 anos tem configurado o mesmo perfil de aluno que habita os contingentes já apresentados nas análises, como por exemplo: de cor/raça preta, com chefes de família subassalariados e de mães com baixa escolaridade.

Para amparar a discussão sobre as mudanças ocorridas no que se refere às finalidades do ENEM durante duas décadas é preciso esmiuçar os porquês da participação dos estudantes, da popularidade do exame e da grande adesão por parte das redes de ensino privadas e mesmo públicas.

Nesse sentido a Tabela 10 traz o percentual de participantes de acordo com os motivos que os levaram a participar do ENEM por ordem de importância.

\footnotetext{
${ }^{30}$ Acessível em: https://www.ilo.org/brasilia/temas/emprego/WCMS 618420/lang--pt/index.htm. Consulta realizada em 26/02/19.

${ }^{31}$ Acessível em: https://www.ilo.org/brasilia/temas/emprego/WCMS_618420/lang--pt/index.htm. Consulta realizada em 26/02/19.
} 
TABELA 10 - MOTIVOS QUE LEVARAM À PARTICIPAÇÃO NO ENEM 2015 EM RIBEIRÃO PRETO POR ORDEM DE IMPORTÂNCIA

\begin{tabular}{|c|c|c|c|c|c|c|c|}
\hline \multirow{2}{*}{\multicolumn{2}{|c|}{ Motivos para participar do ENEM 2015}} & \multirow{2}{*}{\multicolumn{6}{|c|}{$\begin{array}{c}\text { Escala de } 0 \text { (“nenhuma importância) a } 5 \text { (máxima } \\
\text { importância) }\end{array}$}} \\
\hline & & & & & & & \\
\hline & Pública & $\begin{array}{c}\mathbf{0} \\
1 \%\end{array}$ & $\begin{array}{c}1 \\
1 \%\end{array}$ & \begin{tabular}{c|c}
2 \\
$1 \%$
\end{tabular} & $\begin{array}{c}3 \\
7 \% \\
\end{array}$ & $\begin{array}{c}4 \\
12 \%\end{array}$ & $\frac{5}{79 \%}$ \\
\hline Testar meus conhecimentos & Privada & $3 \%$ & $1 \%$ & $2 \%$ & $6 \%$ & $10 \%$ & $78 \%$ \\
\hline \multirow{2}{*}{$\begin{array}{c}\text { Ingressar na Educação Superior } \\
\text { pública }\end{array}$} & Pública & $1 \%$ & $1 \%$ & $2 \%$ & $6 \%$ & $9 \%$ & $81 \%$ \\
\hline & Privada & $1 \%$ & $0 \%$ & $1 \%$ & $3 \%$ & $5 \%$ & $90 \%$ \\
\hline \multirow{2}{*}{$\begin{array}{c}\text { Ingressar na Educação Superior } \\
\text { privada }\end{array}$} & Pública & $7 \%$ & $5 \%$ & $11 \%$ & $23 \%$ & $17 \%$ & $36 \%$ \\
\hline & Privada & $22 \%$ & $11 \%$ & $16 \%$ & $23 \%$ & $12 \%$ & $16 \%$ \\
\hline \multirow{2}{*}{$\begin{array}{l}\text { Conseguir bolsa de estudos } \\
\text { (Prouni, outras) }\end{array}$} & Pública & $1 \%$ & $1 \%$ & $2 \%$ & $7 \%$ & $11 \%$ & $77 \%$ \\
\hline & Privada & $24 \%$ & $6 \%$ & $8 \%$ & $15 \%$ & $12 \%$ & $36 \%$ \\
\hline \multirow{2}{*}{$\begin{array}{c}\text { Participar do Programa de } \\
\text { Financiamento Estudantil (FIES) }\end{array}$} & Pública & $9 \%$ & $5 \%$ & $8 \%$ & $15 \%$ & $15 \%$ & $47 \%$ \\
\hline & Privada & $28 \%$ & $9 \%$ & $10 \%$ & $17 \%$ & $10 \%$ & $26 \%$ \\
\hline
\end{tabular}

FONTE: INEP/MICRODADOS ENEM 2015

Os dados mais relevantes da Tabela 10 são os percentuais de ambas as redes no que concerne à importância máxima atribuída ao ingresso no ensino superior pública como motivo da participação no ENEM. 90\% dos participantes da rede privada e $81 \%$ da rede pública comprovam o efeito camaleão do exame ao longo de sua vigência, já discutido neste trabalho.

Também se destaca o percentual de $77 \%$ de alunos da rede pública que apontaram máxima importância o pleito por bolsa de estudos como o PROUNI, conforme escala de relevância atribuída a esta opção no questionário socioeconômico do ENEM. .

O percentual mais significativo presente na escala 1 de importância é de $28 \%$ dos participantes da rede privada quanto à participação em Programa de Financiamento, dada, certamente, por sua expectativa de ingresso na educação superior pública. O mesmo vale para o item “ingressar na educação superior privada” e “conseguir bolsa de estudos”. Em sentido inverso, os participantes oriundos da rede pública, mostram que a rede privada de educação superior aparece como uma expectativa mais factível de continuidade dos estudos.

A seguir, a Tabela 11 apresenta o percentual de participantes de Ribeirão Preto considerando sua situação de permanência (abandono, distorção idade/série) no Ensino Médio por dependência administrativa. 
TABELA 11 - PERCENTUAL DE PARTICIPANTES DO ENEM 2015 EM RIBEIRÃO PRETO POR SITUAÇÃO DE PERMANÊNCIA NA ESCOLA DURANTE O ENSINO MÉDIO, SEGUNDO A DEPENDÊNCIA ADMINISTRATIVA

\begin{tabular}{ccc}
\hline & Pública & Privada \\
\hline Não abandonei, nem fui reprovado. & $87,2 \%$ & $96,2 \%$ \\
\hline Não abandonei, mas fui reprovado. & $11,1 \%$ & $3,7 \%$ \\
\hline Abandonei, mas não fui reprovado. & $0,7 \%$ & $0,2 \%$ \\
\hline Abandonei e fui reprovado. & $1,0 \%$ & - \\
\hline FONTE: INEP/MICRODADOS ENEM 2015 & & \\
\hline
\end{tabular}

A principal informação é que a maioria dos participantes, seja da rede pública, seja da privada, teve uma trajetória escolar de sucesso. De qualquer forma a taxa de reprovação entre os oriundos da rede pública é três vezes maior do que a apresentada pelos que vieram da rede privada. A taxa de abandono acompanhada da reprovação é nula nos inscritos da rede privada e só se faz presente entre $1 \%$ dos participantes da rede estadual.

Gradativamente, fica evidenciado que as trajetórias dos alunos da escola pública que participam do ENEM estão vulneráveis a todos os fatores extraescolares apresentados nos indicadores de contexto, o que irá sancionar na análise das proficiências a permeabilidade de seu desempenho na prova. Portanto, não se pode afirmar que esses resultados sejam um indicador confiável do nível de qualidade das escolas.

Considerando que os indicadores gerais de reprovação e abandono no ensino médio público estão bem acima dos apresentados na tabela 11 depreende-se que, no caso dos inscritos vindos da rede pública, optam pelo exame apenas aqueles alunos com uma trajetória escolar sem interrupções, o que se confirma também pela idade média dos participantes.

\subsection{CARACTERÍSTICAS DE DESEMPENHO E INTERAÇÕES COM O CONTEXTO DOS PARTICIPANTES DO ENEM 2015 EM RIBEIRÃO PRETO}

Conhecidas as características dos estudantes participantes do Exame Nacional do Ensino Médio na edição de 2015 em Ribeirão Preto, instaura-se a análise das relações confluentes entre os seus perfis, circunstâncias de origem, características de trajetórias escolares com a variável dependência administrativa, examinando sua culminância nos 
resultados de desempenho do exame, à luz dos conceitos de qualidade, desigualdade social e distribuição de oportunidades, considerando-os como determinantes centrais do desempenho.

A influência das características de origem na diferenciação social depende diretamente do efeito que elas possuem na produção do desempenho escolar, possibilitando o processo de estratificação educacional. Logo, os fatores familiares e de origem e o conjunto de determinantes intraescolares que impactam na qualidade do ensino pressupõem a variação da proficiência constatada nas avaliações externas, sendo também responsáveis pelas mudanças na trajetória acadêmica do aluno.

Como já apontado neste trabalho, as interação entre as características individuais, as de origem socioeconômica e fatores internos da escola confluem para a "fabricação" de resultados considerados “esperados” forjando uma ideia de qualidade.

Nesse aspecto, os resultados divulgados pelo ENEM possibilitam uma análise hierarquizante entre estabelecimentos de ensino e não considera que a proficiência dos indivíduos tem uma forte relação com as características de circunstâncias das suas condições de vida e trajetórias escolares, como já se discutiu anteriormente.

O Gráfico 5 traz informações sobre a faixa de proficiência média pela idade média dos participantes do ENEM 2015 em Ribeirão Preto.

\section{GRÁFICO 5 - PROFICIÊNCIA MÉDIA POR FAIXA DE IDADE DOS PARTICIPANTES DO ENEM 2015 EM RIBEIRÃO PRETO}

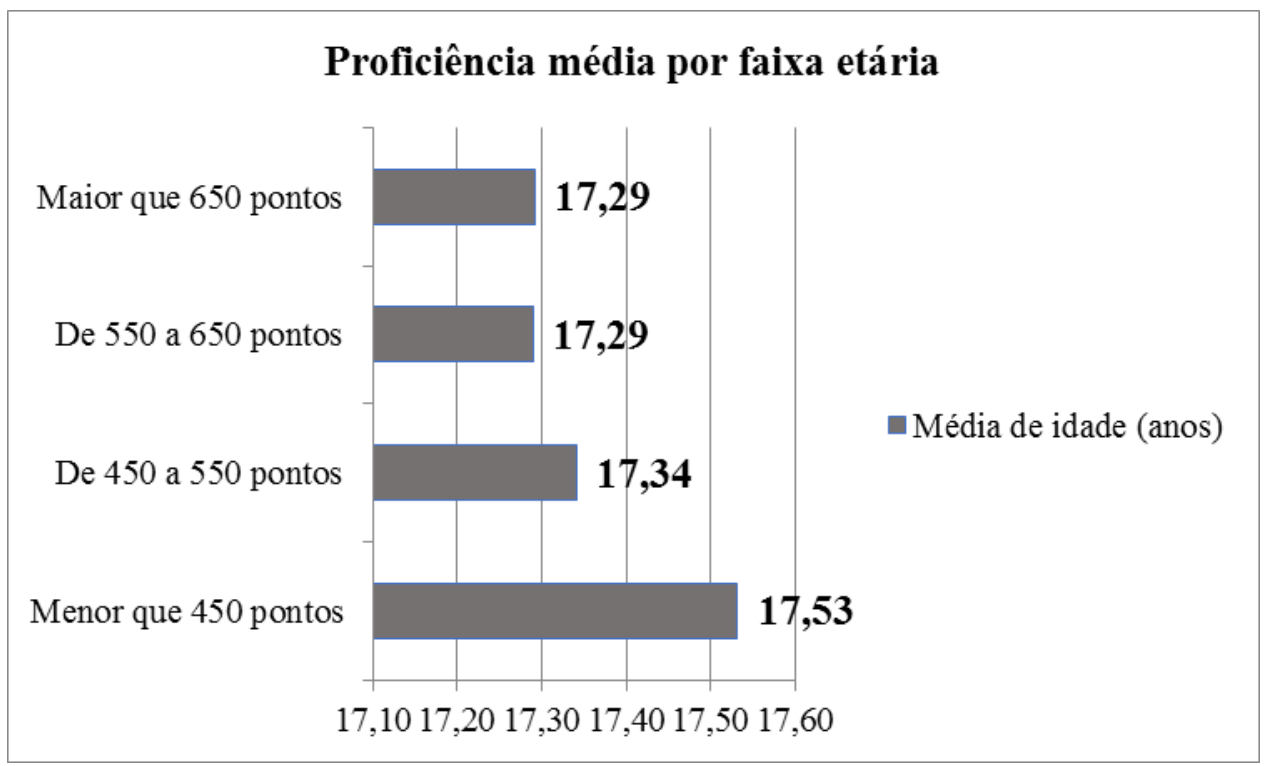

FONTE: INEP/MICRODADOS ENEM 2015 
A variação da faixa etária média de entre as pontuações mais baixas e mais altas é de 0,24 meses. Embora seja uma diferença pequena, observa-se que participantes com mais idade $(17,53)$, que podem indicar exatamente os estudantes com alguma reprovação, são os que obtiveram menor proficiência.

Em comparação com a média nacional segundo estudo dos Microdados do ENEM 2013, apenas 30,4\% dos inscritos conclui o ensino médio com atraso, ou seja, com mais de 20 anos de idade, onde 12,7\% demoram mais de três anos para a conclusão, o que sugere que o ensino médio visto através dos indicadores do ENEM, possivelmente herda taxas de distorção idade/série (PEREIRA, 2015).

A Tabela 12 revela o desempenho médio dos participantes divididos pelo gênero declarado. 
TABELA 12 - QUANTIDADE E PERCENTUAL DE PARTICIPANTES DO ENEM 2015 EM RIBEIRÃO PRETO POR GÊNERO DECLARADO, SEGUNDO FAIXA DE PROFICIÊNCIA MÉDIA

\begin{tabular}{|c|c|c|c|c|}
\hline \multirow{3}{*}{$\begin{array}{l}\text { Faixa de proficiência } \\
\text { média }\end{array}$} & \multicolumn{4}{|c|}{ Participantes } \\
\hline & \multicolumn{2}{|c|}{ Feminino } & \multicolumn{2}{|c|}{ Masculino } \\
\hline & (n) & (\%) & (n) & $(\%)$ \\
\hline Menor que 450 pontos & 262 & $10,80 \%$ & 187 & $10,24 \%$ \\
\hline De 450 a 550 pontos & 1.132 & $46,64 \%$ & 732 & $40,09 \%$ \\
\hline De 550 a 650 pontos & 726 & $29,91 \%$ & 608 & $33,30 \%$ \\
\hline \multirow[t]{3}{*}{ Maior que 650 pontos } & 307 & $12,65 \%$ & 299 & $16,37 \%$ \\
\hline & Total (n) & Total (\%) & Total (n) & Total (\%) \\
\hline & 2.427 & $100 \%$ & 1.826 & $100 \%$ \\
\hline
\end{tabular}

FONTE: INEP/MICRODADOS ENEM 2015

Entre as menores pontuações há equilíbrio no percentual de homens e mulheres, $10,24 \%$ e $10,80 \%$ respectivamente. No entanto, a diferença se alarga quando se refere às maiores pontuações (maior que 750 pontos).

Outros estudos comprovam o avanço da população de mulheres quanto à escolarização, mas os estudantes que tiraram as maiores notas no ENEM são meninos. Dados tabulados pelo INEP (2015) mostram ainda que os jovens do sexo masculino se saem melhor nas quatro áreas cobradas. E a maior diferença está nos exames de Matemática e Ciências da Natureza. Portanto, quando se compara a correlação de desempenho de acordo com o gênero, as médias de desempenho favorecem o gênero masculino. Igualmente atrelado ao baixo desempenho, está a questão da raça e etnia. Para investigar esta associação entre as características de cor/raça como ferramenta de análise utilizou-se tabela de referência cruzada procurando estabelecer relação entre duas variáveis e perceber a distribuição percentual das faixas de desempenho.

A Tabela 13 relaciona o percentual de participantes de Ribeirão Preto segundo a raça/cor declarada e pontuação no ENEM 2015. Cabe salientar que os estratos de raça branca e amarela foram somados, assim como preta e parda. As proficiências denominadas "Mais de 
750 pontos” foram incorporadas à média “De 650 a 750” em virtude do baixo número de participantes situados no topo da pontuação.

TABELA 13 - QUANTIDADE E PERCENTUAL DE PARTICIPANTES NO ENEM 2015 EM RIBEIRÃO PRETO POR RAÇA/COR DECLARADA, SEGUNDO FAIXA DE PROFICIÊNCIA MÉDIA

\begin{tabular}{l|c|c|c|c}
\hline Proficiência & Branca e amarela & $\begin{array}{c}\text { Preta e } \\
\text { parda }\end{array}$ & Indígena & Não consta \\
\hline Menor que 450 & $55,1 \%$ & $44,3 \%$ & $0,2 \%$ & $0,4 \%$ \\
\hline De 450 a 550 & $64,8 \%$ & $34,3 \%$ & $0,3 \%$ & $0,6 \%$ \\
\hline De 550 a 650 & $80,6 \%$ & $17,8 \%$ & $0,2 \%$ & $1,3 \%$ \\
\hline Mais de 650 & $90,8 \%$ & $6,9 \%$ & - & $2,3 \%$ \\
\hline
\end{tabular}

Os dados de resultado do ENEM 2015 de Ribeirão Preto refletem claramente os dados nacionais que evidenciam a grande distância no que tange às oportunidades educacionais entre brancos e negros, motivada, entre outros fatores, pelo forte componente econômico da desigualdade racial brasileira, mas não apenas por isso.

Enquanto 90,8\% dos participantes que atingiram a maior faixa de pontuação eram brancos ou amarelos os participantes pretos e pardos representavam apenas 6,9\% Na faixa de desempenho mais baixa (menor que 450 pontos) encontra-se um percentual 44,3\% de pretos e pardos e 51,1\% de brancos e amarelos, o que mostra uma super-representação de negros e pardos que representam apenas 28,1\% dos participantes do ENEM de Ribeirão Preto, enquanto os brancos e amarelos representam 70,7\% conforme a Tabela 3 deste trabalho sobre o perfil dos inscritos.

Levando em conta a raça, sabe-se que mesmo entre estudantes de escolas particulares, portanto com níveis socioeconômicos similares, o desempenho não é igual ao desempenho de alunos brancos, de acordo com publicação do INEP em $2003^{32}$.

A Tabela 14 descreve a pontuação média dos participantes do ENEM 2015 em Ribeirão Preto na prova de acordo com a escolaridade alcançada pela mãe.

\footnotetext{
${ }^{32}$ Acessível em: http://portal.inep.gov.br/artigo/-/asset_publisher/B4AQV9zFY7Bv/content/piora-na-qualidade do-ensino-afeta-mais-estudantes-negros/21206. Consulta realiza em 24/02/2019.
} 
TABELA 14 - PERCENTUAL DE PARTICIPANTES DO ENEM 2015 EM RIBEIRÃO PRETO POR FAIXA DE PROFICIÊNCIA MÉDIA, SEGUNDO A ESCOLARIDADE DA MÃE

\begin{tabular}{|c|c|c|c|c|}
\hline $\begin{array}{c}\text { Até que série sua mãe, ou } \\
\text { a mulher responsável por } \\
\text { você, estudou? }\end{array}$ & $\begin{array}{c}\text { Menor } \\
\text { que } 450\end{array}$ & $\begin{array}{c}\text { De } 450 \text { a } \\
550\end{array}$ & $\begin{array}{c}\text { De } 550 \text { a } \\
650\end{array}$ & $\begin{array}{l}\text { Maior que } \\
650\end{array}$ \\
\hline Nunca estudou. & $0,9 \%$ & $0,2 \%$ & $0,2 \%$ & $0,2 \%$ \\
\hline $\begin{array}{l}\text { Não completou a } 4^{\mathrm{a}} \\
\text { série/ } / 5^{\circ} \text { ano do Ensino } \\
\text { Fundamental. }\end{array}$ & $11,1 \%$ & $5,9 \%$ & $2,3 \%$ & $0,5 \%$ \\
\hline $\begin{array}{l}\text { Completou a } 4^{\mathrm{a}} \text { série } / 5^{\circ} \\
\text { ano, mas não completou a } \\
8^{\mathrm{a}} \text { série/ } / 9^{\circ} \text { ano do EF. }\end{array}$ & $15,8 \%$ & $13,8 \%$ & $4,9 \%$ & $1,2 \%$ \\
\hline $\begin{array}{c}\text { Completou a } 8^{\mathrm{a}} \text { série/ } 9^{\circ} \\
\text { ano do EF, mas não } \\
\text { completou o Ensino } \\
\text { Médio } \\
\end{array}$ & $24,1 \%$ & $20,5 \%$ & $10,5 \%$ & $3,8 \%$ \\
\hline $\begin{array}{c}\text { Completou o Ensino } \\
\text { Médio, mas não } \\
\text { completou a Faculdade. }\end{array}$ & $37,2 \%$ & $42,3 \%$ & $41,0 \%$ & $22,1 \%$ \\
\hline $\begin{array}{l}\text { Completou a Faculdade, } \\
\text { mas não completou a Pós- } \\
\text { graduação. }\end{array}$ & $5,8 \%$ & $10,5 \%$ & $26,9 \%$ & $42,2 \%$ \\
\hline $\begin{array}{l}\text { Completou a Pós- } \\
\text { graduação. }\end{array}$ & $1,6 \%$ & $4,0 \%$ & $13,1 \%$ & $29,5 \%$ \\
\hline Não sei. & $3,6 \%$ & $2,8 \%$ & $1,0 \%$ & $0,5 \%$ \\
\hline
\end{tabular}

FONTE: INEP/MICRODADOS ENEM 2015

Os desempenhos não estão apenas subordinados aos imperativos do esforço individual, mas sim da origem e da implicação do capital cultural, que segundo Bourdieu (1979), tem peso maior que o fator econômico, apresentando-se de três formas distintas: incorporado, objetivado e institucionalizado.

Segundo Bonamino, Cazelli, Alves e Franco (2010), para Bourdieu, o capital cultural no estado incorporado, tem como principais elementos os gostos, o domínio maior ou menor da língua culta e instruções sobre o mundo escolar. A internalização deste tipo de capital exige investimentos e não pode ser inculcado simplesmente pela hereditariamente.

O capital cultural, no seu estado incorporado, constitui o componente do contexto familiar que atua de forma mais marcante na definição do futuro escolar da prole, uma vez que as referências culturais, os conhecimentos considerados apropriados e legítimos e o domínio maior ou menor da língua culta trazida de casa (herança familiar) facilitam o aprendizado dos conteúdos e dos códigos escolares, funcionando como uma ponte entre o mundo da família e o da escola (BONAMINO; CAZELLI; ALVES; FRANCO, 2010, p. 492).

Sobre o estado objetivado, os autores acrescentam que 
O capital cultural existe na forma de bens culturais, tais como esculturas, pinturas, livros etc. Para possuir os bens econômicos na sua materialidade, é necessário ter simplesmente capital econômico, o que se evidencia na compra de livros, por exemplo. Todavia, para apropriar-se simbolicamente desses bens é necessário possuir os instrumentos dessa apropriação e os códigos necessários para decifrá-los, ou seja, é necessário possuir capital cultural no estado incorporado (BONAMINO; CAZELLI; ALVES; FRANCO, 2010, p. 492).

E finalmente, o estado institucionalizado de capital cultural para esses autores: “ocorre basicamente na forma de títulos escolares. O grau de investimento na carreira escolar está vinculado ao retorno provável que se pode obter com o título escolar, notadamente no mercado de trabalho” (BONAMINO; CAZELLI; ALVES; FRANCO, 2010, p. 492).

Segundo Bonamino, Cazelli, Alves e Franco (2010), para Coleman o conceito de capital cultural se retrata no capital humano que é medido aproximadamente pelo nível de instrução das pessoas.

\footnotetext{
No caso das famílias, o capital humano, medido pela instrução dos pais, é potencialmente importante para proporcionar um ambiente cognitivo propício à aprendizagem escolar da criança [...] Em síntese, a definição de Coleman de capital humano guarda comunalidades com a definição de capital cultural institucionalizado de Bourdieu” (BONAMINO; CAZELLI; ALVES; FRANCO, 2010, p. 492).
}

Algumas pesquisas exploram e confirmam o "efeito escolaridade da mãe” sobre desempenho escolar. Recai sobre a mulher a responsabilização sobre o sucesso escolar das crianças, sob a ideia legitimada de que as mães fiscalizam mais o trabalho dos professores e da escola e que os alunos aprendem mais os conteúdos quando as mães mais escolarizadas dão auxílio nas tarefas domésticas.

Dos dados das redes de ensino de Ribeirão Preto, é possível notar que os maiores percentuais correspondem às mães com nível médio de instrução e curso superior. Entretanto, corroborando com a tendência dos estudos sobre fatores familiares sobre o desempenho, entres a faixa de proficiência mais alta (maior que 650 pontos) estão 71,7\% das mães que concluíram o Ensino Superior, ao passo que 37,2\% das mães dos participantes na faixa abaixo de 450 (menor faixa de desempenho médio) estudaram até o Ensino Médio, lembrando que 40\% das mães dos participantes da rede pública encontram-se neste nível, conforme detalha a Tabela 4. Nessa faixa menor, 51,9\% dos participantes possuem mães com escolaridade inferior ao ensino médio completo.

De acordo com Reis e Ramos (2011, p. 191), “melhorar a quantidade e a qualidade da educação adquirida pelos indivíduos cujos pais ou mães possuem baixos níveis de 
educação, que possuem uma probabilidade maior de pertencer aos estratos mais pobres da população, deve ser um importante instrumento para diminuir a desigualdade”.

As desigualdades sociais oriundas das diferentes condições socioeconômicas precedem a desigualdade nos resultados de desempenho. Daí emergem indicadores de contexto que conferem grande influência sobre os dados de proficiência do ENEM, conforme se pode observar nos dados analisados ao longo deste capítulo.

A Tabela 15 indica a proficiência média dos participantes do ENEM 2015 na cidade de Ribeirão Preto de acordo com os grupos de ocupação ${ }^{33}$ da mãe.

Algumas pesquisas exploram e confirmam o "efeito escolaridade da mãe" sobre desempenho escolar. Recai sobre a mulher a responsabilização sobre o sucesso escolar das crianças, sob a ideia legitimada de que as mães fiscalizam mais o trabalho dos professores e da escola e que os alunos aprendem mais os conteúdos quando as mães mais escolarizadas dão auxílio nas tarefas domésticas.

Dos dados das redes de ensino de Ribeirão Preto, é possível notar que os maiores percentuais correspondem às mães com nível médio de instrução e curso superior. Entretanto, corroborando com a tendência dos estudos sobre fatores familiares sobre o desempenho, entres a faixa de proficiência mais alta (maior que 650 pontos) estão 71,7\% das mães que concluíram o Ensino Superior, ao passo que 37,2\% das mães dos participantes na faixa abaixo de 450 (menor faixa de desempenho médio) estudaram até o Ensino Médio, lembrando que 40\% das mães dos participantes da rede pública encontram-se neste nível, conforme detalha a Tabela 4. Nessa faixa menor, 51,9\% dos participantes possuem mães com escolaridade inferior ao ensino médio completo.

De acordo com Reis e Ramos (2011, p. 191), “melhorar a quantidade e a qualidade da educação adquirida pelos indivíduos cujos pais ou mães possuem baixos níveis de educação, que possuem uma probabilidade maior de pertencer aos estratos mais pobres da população, deve ser um importante instrumento para diminuir a desigualdade”.

As desigualdades sociais oriundas das diferentes condições socioeconômicas precedem a desigualdade nos resultados de desempenho. Daí emergem indicadores de

\footnotetext{
33 Grupo 1: Lavrador(a), agricultor(a) sem empregados, boia fria, criador(a) de animais, apicultor(a), pescador(a), lenhador(a), seringueiro(a), extrativista. Grupo 2: Diarista, empregado(a) doméstico(a), cuidador(a) de idosos, babá, cozinheiro(a) (em casas particulares), motorista particular, jardineiro(a), faxineiro(a), vigilante, porteiro(a), carteiro(a), office-boy, vendedor(a), caixa, atendente de loja, auxiliar administrativo(a), recepcionista, servente de pedreiro, repositora de mercadoria. Grupo 3: Padeiro(a), cozinheiro(a) industrial, sapateiro(a), costureiro(a), joalheiro(a), torneiro(a) mecânico(a), operador(a) de máquinas, soldador(a), operário(a) de fábrica, trabalhador(a) da mineração, pedreiro(a), pintor(a), eletricista, encanador(a), motorista, caminhoneiro(a), taxista. (continuação na próxima nota explicativa)
} 
contexto que conferem grande influência sobre os dados de proficiência do ENEM, conforme se pode observar nos dados analisados ao longo deste capítulo.

A Tabela 15 indica a proficiência média dos participantes do ENEM 2015 na cidade de Ribeirão Preto de acordo com os grupos de ocupação ${ }^{34}$ da mãe.

TABELA 15 - PERCENTUAL DE PARTICIPANTES POR OCUPAÇÃO DA MÃE, SEGUNDO FAIXA DE PROFICIÊNCIA MÉDIA

\begin{tabular}{c|c|c|c|c|c|c}
\hline Ocupação da mãe & Grupo 1 & Grupo 2 & Grupo 3 & Grupo 4 & Grupo 5 & Não sabe \\
\hline Menor que 450 & $2 \%$ & $57 \%$ & $9 \%$ & $16 \%$ & $3 \%$ & $13 \%$ \\
\hline De 450 a 550 & $1 \%$ & $50 \%$ & $11 \%$ & $23 \%$ & $41 \%$ & $12 \%$ \\
\hline De 550 a 650 & $1 \%$ & $25 \%$ & $8 \%$ & $40 \%$ & $16 \%$ & $11 \%$ \\
\hline De 650 a 750 & $0 \%$ & $11 \%$ & $2 \%$ & $47 \%$ & $32 \%$ & $7 \%$ \\
\hline Maior que 750 & - & $6 \%$ & - & $42 \%$ & $44 \%$ & $8 \%$ \\
\hline
\end{tabular}

FONTE: INEP/MICRODADOS ENEM 2015

Na faixa mais baixa de pontuação, menor que 450 pontos estão as mães de participantes que ocupam o Grupo 2 composto por trabalhadoras com baixos salários como diaristas, empregadas doméstica, recepcionistas e baixos postos no comércio. Este grupo tem predominância em aproximadamente 60\% na ocupação das mães de participantes do ENEM 2015 em Ribeirão. Neste grupo elas representam 57\% das mães dos alunos com as mais baixas notas, na mesma faixa de proficiência, as mães do Grupo 5 representam apenas 6\%. Chama atenção a ausência de representação do Grupo 1, o que pode indicar que os estudantes cujas mães pertencem a esse grupo, sequer conseguem ingressar no ensino médio e participar do ENEM.

Em sentido oposto, 86\% dos participantes com média maior que 750 possuem mães nos grupos 4 e 5, que incluem ocupações de maior escolaridade e prestígio social.

${ }^{34}$ G 1: Lavrador(a), agricultor(a) sem empregados, boia fria, criador(a) de animais, apicultor(a), pescador(a), lenhador(a), seringueiro(a), extrativista. G 2: Diarista, empregado(a) doméstico(a), cuidador(a) de idosos, babá, cozinheiro(a) (em casas particulares), motorista particular, jardineiro(a), faxineiro(a), vigilante, porteiro(a), carteiro(a), office-boy, vendedor(a), caixa, atendente de loja, auxiliar administrativo(a), recepcionista, servente de pedreiro, repositora de mercadoria. G 3: Padeiro(a), cozinheiro(a) industrial, sapateiro(a), costureiro(a), joalheiro(a), torneiro(a) mecânico(a), operador(a) de máquinas, soldador(a), operário(a) de fábrica, trabalhador(a) da mineração, pedreiro(a), pintor(a), eletricista, encanador(a), motorista, caminhoneiro(a), taxista. (continuação na próxima nota explicativa) 
Para retomarmos a análise apoiada no conceito de capital econômico, bem como sua relação com a produção de resultados de desempenho escolares, a Tabela 16, traz a proficiência média dos participantes de acordo com a ocupação ${ }^{35}$ do pai.

TABELA 16 - PERCENTUAL DE PARTICIPANTES POR OCUPAÇÃO DO PAI, SEGUNDO FAIXA DE PROFICIÊNCIA MÉDIA

\begin{tabular}{c|c|c|c|c|c|c}
\hline Ocupação do Pai & Grupo 1 & Grupo 2 & Grupo 3 & Grupo4 & Grupo 5 & $\begin{array}{c}\text { Não } \\
\text { sabe }\end{array}$ \\
\hline Menor que 450 & $3 \%$ & $26 \%$ & $35 \%$ & $16 \%$ & $4 \%$ & $16 \%$ \\
\hline De 450 a 550 & $2 \%$ & $22 \%$ & $31 \%$ & $26 \%$ & $7 \%$ & $12 \%$ \\
\hline De 550 a 650 & $2 \%$ & $11 \%$ & $19 \%$ & $38 \%$ & $23 \%$ & $7 \%$ \\
\hline De 650 a750 & $1 \%$ & $4 \%$ & $7 \%$ & $40 \%$ & $45 \%$ & $3 \%$ \\
\hline Maior que 750 & $2 \%$ & $3 \%$ & $2 \%$ & $40 \%$ & $52 \%$ & $2 \%$ \\
\hline
\end{tabular}

FONTE: INEP/MICRODADOS ENEM 2015

De forma análoga à situação das mães, mas de forma mais acentuada, 92\% dos estudantes com notas mais elevadas possuem pais que pertencem aos grupos 4 e 5 . Já entre os alunos de pior desempenho 64\% pertencem aos grupos 1 , 2 e 3 e apenas $20 \%$ aos grupos 4 e 5 .

O gráfico abaixo sintetiza o que explicitam as análises sobre os capitais e seu peso como determinante na vida escolar, indicando a proficiência dos participantes por percentual de acordo com estratos de renda mensal familiar.

${ }^{35}$ G 4: Professor(a), técnico(a) (de enfermagem, contabilidade, eletrônica etc.), policial, militar de baixa patente, corretor(a) de imóveis, supervisor(a), gerente, mestre de obras, pastor(a), microempresário(a) (proprietário(a) de empresa com menos de 10 empregados), pequeno(a) comerciante, pequeno(a) proprietário(a) de terras, trabalhador(a) autônomo(a) ou por conta própria. G 5: Médico(a), engenheiro(a), dentista, psicólogo(a), economista, advogado(a), juiz(a), promotor(a), defensor(a), delegado(a), tenente, capitão(ã), coronel, professor(a) universitário(a), diretor(a) em empresas públicas e privadas, político(a), proprietário(a) de empresas com mais de 10 empregados. 
GRÁFICO 6 - PERCENTUAL DE PARTICIPANTES DO ENEM 2015 EM RIBEIRÃO PRETO POR RENDA MENSAL FAMILIAR, SEGUNDO FAIXA DE PROFICIÊNCIA MÉDIA

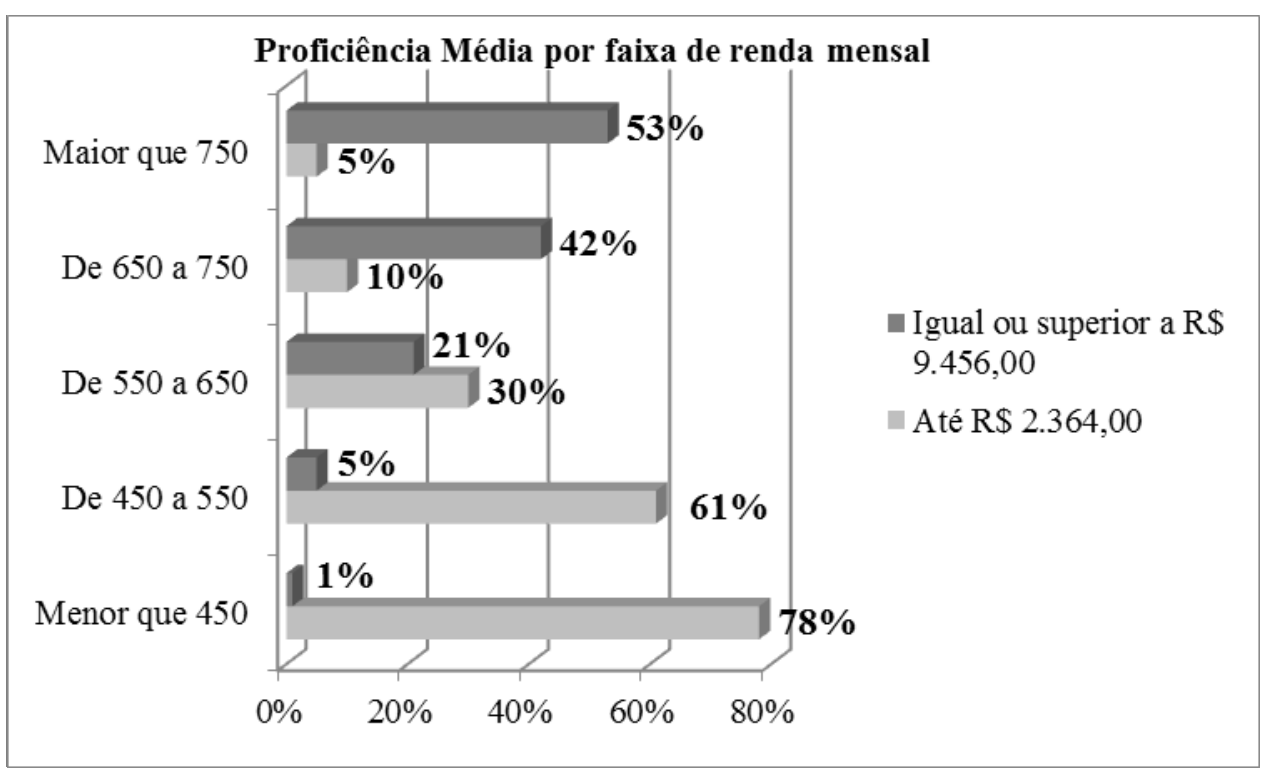

FONTE: INEP/MICRODADOS ENEM 2015

Obs: Para melhor visualização foram selecionadas apenas as faixas de renda mais extremas.

$78 \%$ dos respondentes que indicaram a faixa de renda mais baixa de até $\mathrm{R} \$ 2.346,00$ por mês ocupam a faixa de desempenho mais baixa, enquanto os $53 \%$ dos participantes que indicaram a maior faixa de renda obtiveram nota maior que 750 pontos.

No outro extremo, apenas $5 \%$ dos declarantes que alcançaram nota maior que 750 pontos possuem renda mensal familiar até R \$ 2.364,00, e 53\% que atingiram esta pontuação declararam ganho mensal igual ou superior a R\$ 9.456,00.

Relembrando a importância da presença de empregada doméstica como um diferencial importante da riqueza das famílias, o Gráfico 7 apresenta a relação entre o desempenho dos participantes do ENEM 2015 de Ribeirão Preto através do status e prestígio (que faz menção ao capital simbólico), aqui considerado o “poder” ou possiblidade de contratar empregada doméstica. 


\section{GRÁFICO 7 - PERCENTUAL DE PARTICIPANTES DO ENEM 2015 EM RIBEIRÃO PRETO QUE DECLARARAM PRESENÇA/FREQUÊNCIA DE EMPREGADA DOMÉSTICA EM RESIDÊNCIA, SEGUNDO FAIXA DE PROFICIÊNCIA}

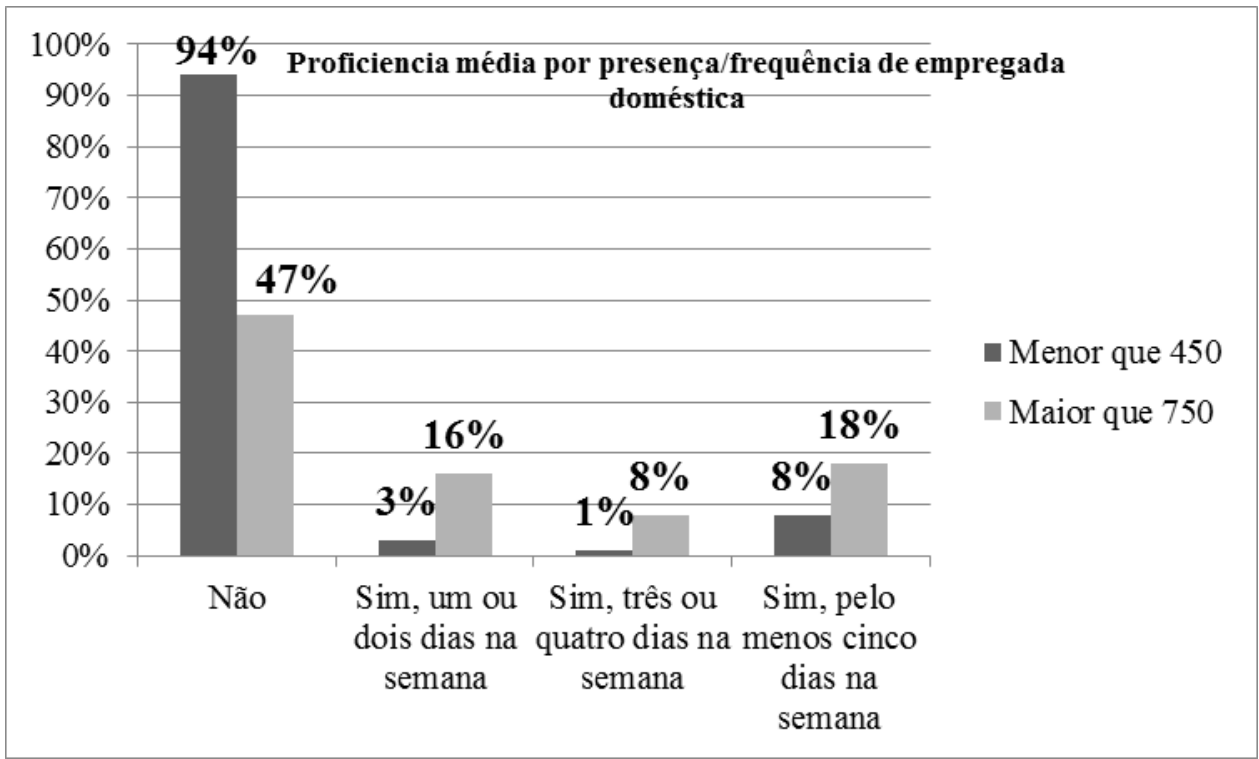

FONTE: INEP/MICRODADOS ENEM 2015

Obs: Foram selecionadas apenas as faixas extremas de desempenho.

É válido sublinhar que o capital simbólico é subjacente ao capital econômico, o que faz repetir a tendência constatada nas análises da renda familiar e de ocupação dos pais. Ainda assim, é relevante que 94\% dos participantes com baixo desempenho (menor que 450) declararam não contar com a presença de empregada doméstica em sua residência, contra $47 \%$ dos participantes no outro extremo das faixas de desempenho.

A tabela 17 revela um fator central que incide sobre o desempenho: o percentual dos participantes do ENEM 2015 em Ribeirão Preto segundo sua proficiência média de acordo com sua participação no mercado de trabalho. 
TABELA 17 - PERCENTUAL DE PARTICIPANTES DO ENEM 2015 EM RIBEIRÃO PRETO E SUA EXPERÊNCIA LABORAL, SEGUNDO FAIXA DE PROFICIÊNCIA

\begin{tabular}{cccccc}
\hline & $\begin{array}{c}\text { Menor que } \\
\mathbf{4 5 0}\end{array}$ & De 450 a 550 & De 550 a 650 & De 650 a 750 & Maior que 750 \\
\hline $\begin{array}{c}\text { Não, nunca } \\
\text { trabalhei. }\end{array}$ & $\mathbf{4 9 \%}$ & $58 \%$ & $79 \%$ & $\mathbf{9 2 \%}$ & $\mathbf{1 0 0 \%}$ \\
$\begin{array}{c}\text { Sim, já trabalhei, } \\
\text { mas não estou } \\
\text { trabalhando. }\end{array}$ & $\mathbf{2 0 \%}$ & $\mathbf{1 6 \%}$ & $\mathbf{1 2 \%}$ & $\mathbf{6 \%}$ & - \\
$\begin{array}{c}\text { Sim, estou } \\
\text { trabalhando. }\end{array}$ & $32 \%$ & $\mathbf{2 6 \%}$ & $\mathbf{9 \%}$ & $\mathbf{2 \%}$ & - \\
\hline
\end{tabular}

FONTE: INEP/MICRODADOS ENEM 2015

Dos que declaram nunca ter trabalhado, o percentual mais eminente é quanto à média mais elevada: 100\% dos participantes que alcançaram as maiores pontuações nunca trabalharam. Entre as pontuações inferiores a 450 pontos, $49 \%$ declararam nunca ter tido nenhuma experiência no mundo trabalho.

Deve-se considerar que a média de idade dos participantes é de 17,4 para ambas as redes e 52\% dos participantes que atingiram a menor faixa de desempenho pelo menos já tiveram alguma experiência na vida laboral, sendo que 32\% exerciam alguma atividade no período do ENEM em 2015.

Os percentuais de participantes se apresentam regressivamente e inversamente proporcionais ao aumento da faixa de proficiência, o que pode suscitar uma potencial perda de qualidade na trajetória acadêmica, no aproveitamento escolar e aprendizagem, tendo em vista a necessidade de dedicação ao trabalho, à escola e a outros aspectos da vida cotidiana, o que pode gerar até tripla jornada de atividades diárias.

A Tabela 18 apresenta o percentual de participantes e suas proficiências médias por tipo de instituição de origem no Ensino Médio e remetem à discussão já realizada sobre os rankings e sobre o mercado que se ergueu em torno da nota do ENEM e o prestígio atribuído a determinados grupos de colégios privados que utilizam deste prestígio para forjar uma ideia de qualidade e buscar atrair os alunos com maior chance de sucesso no exame, inclusive através de concurso de bolsas para egressos da rede pública. 
TABELA 18 - PERCENTUAL DE PARTICIPANTES DO ENEM 2015 EM RIBEIRÃO PRETO POR TIPO DE INSTITUIÇÃO ESCOLAR FREQUENTADA NO ENSINO MÉDIO, SEGUNDO FAIXA DE PROFICIÊNCIA MÉDIA

\begin{tabular}{|cccccc}
\hline $\begin{array}{c}\text { Tipo de instituição frequentada no } \\
\text { Ensino Médio }\end{array}$ & $\begin{array}{c}\text { Menor que } \\
\mathbf{4 5 0}\end{array}$ & $\begin{array}{c}\text { De 450 } \\
\text { a 550 }\end{array}$ & $\begin{array}{c}\text { De 550 } \\
\text { a 650 }\end{array}$ & $\begin{array}{c}\text { De 650 } \\
\text { a 750 }\end{array}$ & $\begin{array}{c}\text { Maior } \\
\text { que 750 }\end{array}$ \\
\hline Somente em escola pública. & $92,2 \%$ & $75,0 \%$ & $30,4 \%$ & $5,0 \%$ & - \\
\hline $\begin{array}{c}\text { Parte em escola pública e parte em escola } \\
\text { privada sem bolsa de estudo integral. }\end{array}$ & $1,1 \%$ & $3,5 \%$ & $2,8 \%$ & $1,5 \%$ & - \\
$\begin{array}{c}\text { Parte em escola pública e parte em escola } \\
\text { privada com bolsa de estudo integral. }\end{array}$ & $0,7 \%$ & $1,2 \%$ & $0,9 \%$ & $0,4 \%$ & - \\
\hline $\begin{array}{c}\text { Somente em escola privada sem bolsa de } \\
\text { estudo integral. }\end{array}$ & $4,7 \%$ & $16,5 \%$ & $54,9 \%$ & $83,5 \%$ & $93,5 \%$ \\
\hline $\begin{array}{c}\text { Somente em escola privada com bolsa de } \\
\text { estudo integral. }\end{array}$ & $1,3 \%$ & $3,8 \%$ & $11,0 \%$ & $9,7 \%$ & $6,5 \%$ \\
\hline FONTE: INEP/MICRODADOS ENEM 2015 & & & & & \\
\hline
\end{tabular}

FONTE: INEP/MICRODADOS ENEM 2015

Os dados da tabela 10 correspondem ao material básico de propaganda usado pelas escolas privadas e pelos economistas ligados ao mercado para afirmar que a rede privada é muito melhor que a rede pública. Afinal, apenas 6\% dos alunos com menor desempenho cursaram o ensino médio em escolas privadas, enquanto 94\% estudaram total ou parcialmente na rede pública. No sentido oposto, 100\% dos alunos de maior desempenho só estudaram em escolas privadas. Na faixa de 650 a 750 pontos, 93,2\% estudaram apenas em escolas privadas e apenas 5\% apenas em escolas públicas.

Contudo, diferentemente dos dados expostos neste capítulo, os dados da Tabela 18 mais ocultam que iluminam. O melhor desempenho das escolas privadas decorre exatamente dos critérios seletivos que elas adotam na escolha de seus alunos (capital econômico e cultural). Como os dados aqui apresentados indicam, corroborando todos os estudos da área, o principal fator explicativo de desempenho é o capital cultural altamente correlacionado com o capital econômico, ainda mais no Brasil, um país em que o acesso aos níveis mais elevados de ensino é um privilégio das classes mais abastadas. Os filhos de professores da educação básica, por exemplo, que costumam apresentar razoável desempenho no ENEM e nos processos seletivos de universidades públicas, talvez representem um dos poucos casos em que o capital cultural se “descola” do capital econômico.

Diante disso, cabe, pois, concluir que o efeito do capital cultural, que não se trata apenas do acesso aos bens de consumo que o capital econômico pode adquirir, mas daquilo se faz com o conhecimento ao qual se tem acesso, é diferencial e determinante na produção dos resultados de desempenho escolar. 
Quanto mais expostos estão os participantes aos fatores extraescolares de origem socioeconômica, mais afetados são seus resultados na prova. Os dados analisados permitem problematizar o indicador de dependência administrativa como o fator determinante de desempenho.

Embora o ENEM não avalie a escola, é admissível afirmar que o tipo de escola prevê seus resultados do ENEM pela força do público que a frequenta. Por outro lado, o desempenho dos participantes da rede privada não faz supor efeito da qualidade de suas escolas, pois têm seu desempenho sustentado por inputs favoráveis, ou seja, fatores extraescolares de origem, socioeconômicos, entre outros diversos capitais, que colocam em vantagem seus alunos quanto à distribuição de oportunidades educacionais.

Ademais, levando em conta os interesses publicitários que interpelavam o rankeamento das escolas, pode-se dizer tratar-se da "máscara da qualidade" o fato de a divulgação dos resultados permitirem, antes da suspensão da divulgação do "ENEM por Escola”, em 2017, comparações entre perfis muito distintos de escolas (quando o ENEM avalia apenas o aluno) e os resultados serem usados de forma enviesada pelas instituições de elite.

Devido a isso, é incontroverso o fato de que o ENEM não pode ser considerado como um descritor da qualidade das escolas, mas que, antes, seus resultados quando discriminados por tipo de escola, servem para demonstrar quão estratificado por renda, etnia e escolaridade dos pais é o ensino médio brasileiro.

O alunado da escola pública ribeirão-pretana participante do ENEM 2015 pode, portanto, representar o público potencial das políticas afirmativas que marcaram as duas últimas décadas no contexto da expansão do acesso ao Ensino Superior. Trata-se de uma demanda advinda das classes mais pobres que poderiam vir a serem os primeiros sujeitos de seus núcleos familiares a ingressar em uma universidade impulsionados pelo anseio de mobilidade social.

Concomitantemente às políticas educacionais de ampliação do acesso à educação básica implementadas ao longo das edições do ENEM, estes aspectos redesenharam o Ensino Médio nas últimas décadas. Entende-se, portanto que o público do Ensino Médio se justapôs às mudanças do ENEM desde a sua concepção em 1998.

No item a seguir discutiremos os mesmos indicadores de contexto e desempenho, agora discriminados por escola. 


\subsection{RESULTADOS DO ENEM 2015 POR ESCOLA - RIBEIRÃO PRETO}

Os dados de desempenho no ENEM 2015 foram submetidos ao cruzamento com as variáveis de contexto indicadas no Dicionário do ENEM 2015, assim como nas respostas dos participantes no preenchimento do questionário socioeconômico.

A partir de uma base padronizada de níveis agregados por escola do município de Ribeirão Preto foi possível elaborar tabelas com estatísticas descritivas a partir do cruzamento das seguintes variáveis:

- Participação de alunos matriculados no Ensino Médio;

- Raça/cor;

- Escolaridade da mãe;

- Renda Mensal;

- Exercício de atividade remunerada.

- Alunos da rede privada que cursaram o Ensino Médio com bolsa de estudos.

Do total de alunos que fizeram o ENEM 2015 em Ribeirão Preto foram assim filtrados: a) os alunos concluintes do Ensino Médio, para tanto, foram considerados dados do ENEM por Escola 2015 e Censo Escolar 2015, b) os alunos que estavam presentes em todos os dias de prova e c) os alunos que não entregaram a redação em branco.

O pareamento dos dados do ENEM com os dados do ENEM por Escola deve ser realizado com cautela, uma vez que a participação no exame é de caráter voluntário e, portanto, a representatividade dos resultados varia de acordo com o percentual de participação de estudantes em cada escola ${ }^{36}$.

A divulgação ENEM por Escola, extinta em 2017, utilizava como critério para a divulgação das posições das escolas, possuir pelo menos 10 (dez) alunos concluintes do ensino médio regular seriado participantes do Enem 2015 e possuir pelo menos 50\% de alunos participantes do Enem 2015, de acordo com os dados do Censo Escolar 2015, conforme Portaria N. 501, de 27 de setembro de 2016 que estabelece critérios e procedimentos de cálculo e de divulgação dos resultados do Enem 2015 por Escola.

\footnotetext{
${ }^{36}$ De acordo com a Nota Explicativa dos Microdados de ENEM 2015, o critério para identificar, dentre os inscritos no ENEM 2015, os alunos do ensino médio no Censo Escolar 2015 considerados no ENEM por Escola 2015 foi a identificação do CPF.
} 
A base de dados “Consistência 2015” presente entre os arquivos dos Microdados 2015 contém os alunos de escolas que atenderam aos critérios de divulgação considerados no cálculo do Enem por Escola e, por esta razão, possibilita reproduzir seus resultados. Essa medida foi necessária porque o aluno concluinte do ensino médio que estava, por exemplo, matriculado em duas escolas, de acordo com o Censo Escolar da Educação Básica 2015, teve sua nota computada no resultado de ambas as escolas. Por este motivo não foi possível criar na base Microdados do ENEM 2015 uma variável que indicasse se aquele aluno foi considerado ou não para o cálculo do ENEM por Escola, já que nesta base não há alunos duplicados e consta apenas a escola que o aluno declarou estar matriculado no momento da sua inscrição ${ }^{37}$.

A partir desta base, foi possível ampliar o universo de pesquisa na Tabela 19 abaixo, onde optou-se por incluir as escolas de Ribeirão Preto com taxas de participação ${ }^{38}$ abaixo de $50 \%$, que não se encaixaram nos critérios do ENEM por Escola especificados pela Portaria $n^{\circ}$ 50 de setembro de 2016.

TABELA 19 - PERCENTUAL DE ALUNOS CONCLUINTES DO EM QUE PARTICIPARAM DO ENEM 2015 EM RIBEIRÃO PRETO POR DEPENDÊNCIA ADMINISTRATIVA

\begin{tabular}{c|c|c}
\hline Participação & Nome da escola & $\begin{array}{c}\text { Dependência } \\
\text { administrativa }\end{array}$ \\
\hline $100,0 \%$ & SESI 345 Centro Educacional & Privada \\
\hline $100,0 \%$ & Marista Colégio de Ribeirão Preto & Privada \\
\hline $100,0 \%$ & Barão de Mauá Escola de Ed. Infantil, Ensino & Pundamental e Médio \\
\hline $100,0 \%$ & Nossa Senhora Auxiliadora Colégio & Privada \\
\hline $100,0 \%$ & Adventista de Ribeiro Preto Colégio & Privada \\
\hline $100,0 \%$ & Iavec Vida de Ensino Cristão Instituto Avançado & Privada \\
\hline $100,0 \%$ & Waldorf João Guimarães Rosa Escola & Privada \\
\hline $100,0 \%$ & Samuel Pfromm Netto Liceu & Privada \\
\hline $100,0 \%$ & Objetivo Centro Interescolar Unidade XXVII & Privada \\
\hline $100,0 \%$ & Lacordaire Colégio Ensino Médio & Privada \\
\hline $100,0 \%$ & SEB COC Unidade Álvares Cabral & Privada \\
\hline $98,0 \%$ & Gabarito Colégio & Privada \\
\hline $96,8 \%$ & Barros Cônego & Estadual \\
\hline $96,3 \%$ & SESI 346 Centro Educacional & Privada \\
\hline $94,6 \%$ & Albert Sabin Escola de Ensino Médio & Privada \\
\hline
\end{tabular}

${ }^{37}$ Consta no documento "Leia-me”, que traz breve descrição do ENEM, bem como das informações sobre as bases e os arquivos disponibilizados nos Microdados do ENEM 2015.

${ }^{38}$ A taxa de participação da escola é a razão entre o total de participantes e o total de estudantes que tenham sido matriculados em turmas da $3^{\mathrm{a}}$ série do ensino médio regular de escolas públicas e privadas, de acordo com o Censo Escolar de 2015, multiplicado por 100. 


\begin{tabular}{|c|c|c|}
\hline $94,4 \%$ & SEB COC Unidade Lafaiete & Privada \\
\hline $93,3 \%$ & SESI 298 Centro Educacional & Privada \\
\hline $93,1 \%$ & Liceu Contemporâneo Ensino Médio & Privada \\
\hline $93,0 \%$ & FAAP Ribeirão Preto Colégio & Privada \\
\hline $93,0 \%$ & Djanira Velho Professora & Estadual \\
\hline $92,1 \%$ & $\begin{array}{l}\text { Santa Úrsula Ribeirão Preto Ed. Infantil, Ensino } \\
\text { Fundamental e Médio } \\
\end{array}$ & Privada \\
\hline $90,5 \%$ & Ideal Colégio & Privada \\
\hline $90,1 \%$ & Einstein Colégio & Privada \\
\hline $90,0 \%$ & José Martimiano da Silva ETEC & Estadual \\
\hline $90,0 \%$ & Brasil Colégio & Privada \\
\hline $87,7 \%$ & Metodista de Ribeirão Preto Colégio & Privada \\
\hline $87,5 \%$ & SESI 297 Centro Educacional & Privada \\
\hline $87,2 \%$ & Anchieta Colégio & Privada \\
\hline $86,9 \%$ & Alberto Santos Dumont & Estadual \\
\hline $86,7 \%$ & Vianna Colégio & Privada \\
\hline $86,4 \%$ & Viktor Frankl Colégio Ensino Médio & Privada \\
\hline $85,7 \%$ & Ressurreição Vita Et Pax Colégio & Privada \\
\hline $83,3 \%$ & Cid de Oliveira Leite Professor & Estadual \\
\hline $83,3 \%$ & Almeida Garrett Escola de Ensino Fundamental e Médio & Privada \\
\hline $83,1 \%$ & Cervantes Colégio & Privada \\
\hline $82,5 \%$ & Carlos Chagas Filho Escola Ensino Fundamental e Médio & Privada \\
\hline $80,6 \%$ & SESI 259 Centro Educacional & Privada \\
\hline $79,7 \%$ & Sebastião Fernandes Palma Professor & Estadual \\
\hline $79,5 \%$ & Moura Lacerda Colégio Unidade I & Privada \\
\hline $79,5 \%$ & Miguel Jorge & Estadual \\
\hline $77,8 \%$ & Carlos Magno Colégio & Privada \\
\hline $77,6 \%$ & João Palma Guião Doutor & Estadual \\
\hline $76,7 \%$ & SESI 301 Centro Educacional & Privada \\
\hline $76,5 \%$ & Walter Ferreira Professor & Estadual \\
\hline $75,9 \%$ & SESI 362 Centro Educacional & Privada \\
\hline $75,9 \%$ & Otoniel Mota & Estadual \\
\hline $75,6 \%$ & Romeu Alberti Dom & Estadual \\
\hline $75,0 \%$ & SESI 344 Centro Educacional & Privada \\
\hline $75,0 \%$ & Colégio Batista Independente de Ribeirão Preto & Privada \\
\hline $71,9 \%$ & Dr. Thomaz Alberto Whately & Estadual \\
\hline $71,0 \%$ & Alberto José Gonçalves Dom & Estadual \\
\hline $65,2 \%$ & Guimarães Junior Doutor & Estadual \\
\hline $64,3 \%$ & Castelo Escola Educação Infantil e Ensino Fundamental & Privada \\
\hline $63,1 \%$ & Francisco da Cunha Junqueira Doutor & Estadual \\
\hline $61,7 \%$ & Alcides Correa Professor & Estadual \\
\hline $60,0 \%$ & Expedicionários Brasileiros & Estadual \\
\hline $58,3 \%$ & Espaço Cultural Colégio & Privada \\
\hline $53,2 \%$ & Domingos João Baptista Spinelli Professor Doutor & Estadual \\
\hline $52,9 \%$ & Rafael Leme Franco Professor & Estadual \\
\hline $47,8 \%$ & Geraldo Correia de Carvalho Doutor & Estadual \\
\hline
\end{tabular}




\begin{tabular}{c|c|c}
\hline $46,9 \%$ & Walter Paiva Professor & Estadual \\
\hline $44,8 \%$ & Eugenia Vilhena de Morais Professora & Estadual \\
\hline $44,7 \%$ & Jenny de Toledo Piza Schroeder Professora & Estadual \\
\hline $44,0 \%$ & Irene Dias Ribeiro Professora & Estadual \\
\hline $43,0 \%$ & Jardim Diva Tarla de Carvalho & Estadual \\
\hline $41,3 \%$ & Amélia das Santos Musa Professora & Estadual \\
\hline $36,8 \%$ & Jardim Paiva II & Estadual \\
\hline $36,5 \%$ & Glete de Alcântara Professora & Estadual \\
\hline $36,4 \%$ & Romualdo Monteiro de Barros Professor & Estadual \\
\hline $35,1 \%$ & Alpheu Dominiguetti Professor & Estadual \\
\hline $30,6 \%$ & Jardim Orestes Lopes de Camargo & Estadual \\
\hline $27,7 \%$ & Oscar de Moura Lacerda Professor Doutor & Estadual \\
\hline $27,2 \%$ & João Augusto de Mello Professor & Estadual \\
\hline $23,6 \%$ & Orlando Vitaliano Vereador & Estadual \\
\hline
\end{tabular}

FONTE: INEP/MICRODADOS DO ENEM

Obs: As escolas EMEFEM Dom Luis Amaral Mousinho; SEB COC Unidade Ribeirânia e CEEJA Profa. Cecilia Dultra Caram não foram consideradas porque as informações dos alunos participantes no ENEM 2015 apresentavam inconsistências com os dados divulgados no Censo Escolar 2015.

No total, alunos de setenta escolas participaram do ENEM 2015 na cidade de Ribeirão Preto, excluídas desta análise as dependências administrativas municipais e federais. Nenhuma das trinta e seis escolas da rede privada apresentou taxa de participação inferior a $50 \%$ e todas as escolas que apresentaram taxa de 100\% são também da rede privada.

A escola particular com a menor taxa de participação foi o Colégio Espaço Cultural (imagem 1), com 58,3\%, tendo um total de doze alunos matriculados no terceiro ano do Ensino Médio e apenas sete participantes do ENEM 2015. 


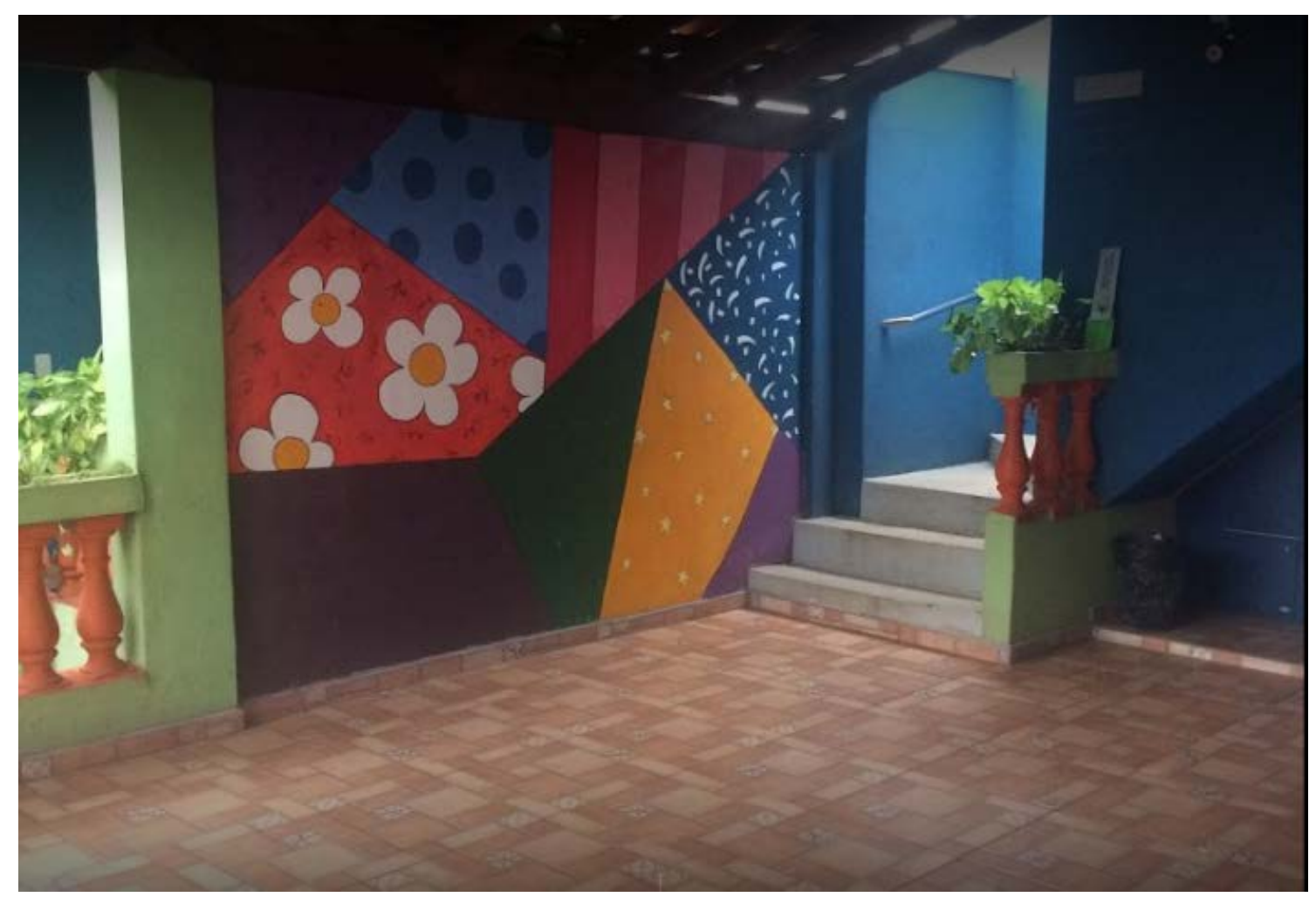

FONTE: GOOGLE MAPS

Dezenove das trinta e quatro escolas estaduais participantes do ENEM atenderam ao critério do INEP para divulgação com taxa igual ou superior a 50\%. A escola Vereador Orlando Vitaliano, apresenta o menor percentual com taxa de participação de 23,6\%. A escola estadual Cônego Barros foi a que atingiu a maior taxa, com 96,8\%.

Nas tabelas a seguir serão consideradas apenas as cinquenta e nove escolas em que o índice de participação foi igual ou superior a 50\% dos alunos do $3^{\circ}$ ano.

A Tabela 20 mostra o percentual de alunos negros participantes ENEM nas redes pública e privada de Ribeirão Preto.

TABELA 20 - ESCOLAS POR DEPENDÊNCIA ADMINISTRATIVA E PERCENTUAL DE PARTICIPANTES NEGROS NO ENEM 2015 EM RIBEIRÃO PRETO

\begin{tabular}{c|c|c|c|c|c}
\hline $\begin{array}{c}\text { Dep. } \\
\text { Adm }\end{array}$ & Escola & $\begin{array}{c}\text { \% } \\
\text { negros }\end{array}$ & $\begin{array}{c}\text { Dep. } \\
\text { Adm }\end{array}$ & $\begin{array}{c}\text { Escola } \\
\text { negros }\end{array}$ \\
\hline Privada & Anchieta Colégio & $0,0 \%$ & Estadual & Joao Palma Guião Doutor & $18,4 \%$ \\
\hline Privada & Samuel Pfromm Netto Liceu & $0,0 \%$ & Privada & $\begin{array}{c}\text { Almeida Garrett Ensino } \\
\text { Fundamental e Médio }\end{array}$ & $20,0 \%$ \\
\hline Privada & $\begin{array}{c}\text { Castelo Escola Educação } \\
\text { Infantil e Fundamental }\end{array}$ & $0,0 \%$ & Estadual & $\begin{array}{c}\text { Francisco da Cunha } \\
\text { Junqueira Doutor }\end{array}$ & $22,0 \%$ \\
\hline Privada & Einstein Colégio & $4,2 \%$ & Estadual & Miguel Jorge & $22,5 \%$ \\
\hline
\end{tabular}




\begin{tabular}{|c|c|c|c|c|c|}
\hline Privada & $\begin{array}{c}\text { SEB COC Unidade Álvares } \\
\text { Cabral }\end{array}$ & $4,3 \%$ & Privada & $\begin{array}{c}\text { Iavec Vida de Ensino } \\
\text { Cristão Instituto Avançado }\end{array}$ & $23,1 \%$ \\
\hline Privada & $\begin{array}{l}\text { FAAP Ribeirão Preto } \\
\text { Colégio } \\
\end{array}$ & $5,7 \%$ & Privada & $\begin{array}{l}\text { SESI } 345 \text { Centro } \\
\text { Educacional } \\
\end{array}$ & $23,3 \%$ \\
\hline Privada & SEB COC Unidade Lafaiete & $6,4 \%$ & Privada & $\begin{array}{l}\text { SESI } 259 \text { Centro } \\
\text { Educacional }\end{array}$ & $24,0 \%$ \\
\hline Privada & $\begin{array}{l}\text { Albert Sabin Escola de } \\
\text { Ensino Médio } \\
\end{array}$ & $6,6 \%$ & Privada & $\begin{array}{l}\text { Ressurreição Vita Et Pax } \\
\text { Colégio }\end{array}$ & $25,0 \%$ \\
\hline Privada & $\begin{array}{l}\text { SESI } 298 \text { Centro } \\
\text { Educacional } \\
\end{array}$ & $7,1 \%$ & Privada & $\begin{array}{l}\text { Metodista de Ribeirão } \\
\text { Preto Colégio }\end{array}$ & $26,0 \%$ \\
\hline Privada & Carlos Magno Colégio & $7,1 \%$ & Privada & $\begin{array}{c}\text { Adventista de Ribeiro Preto } \\
\text { Colégio } \\
\end{array}$ & $28,6 \%$ \\
\hline Privada & $\begin{array}{l}\text { Liceu Contemporâneo } \\
\text { Ensino Médio }\end{array}$ & $7,4 \%$ & Privada & $\begin{array}{l}\text { SESI } 297 \text { Centro } \\
\text { Educacional } \\
\end{array}$ & $28,6 \%$ \\
\hline Privada & $\begin{array}{c}\text { Objetivo Centro Interescolar } \\
\text { Unidade XXVII }\end{array}$ & $7,7 \%$ & Estadual & Alberto Santos Dumont & $29,3 \%$ \\
\hline Privada & $\begin{array}{c}\text { Carlos Chagas Filho Escola } \\
\text { Ensino Fund. e Médio }\end{array}$ & $7,7 \%$ & Privada & $\begin{array}{c}\text { Lacordaire Colégio Ensino } \\
\text { Médio }\end{array}$ & $31,3 \%$ \\
\hline Privada & $\begin{array}{c}\text { Viktor Frankl Colégio } \\
\text { Ensino Médio } \\
\end{array}$ & $10,5 \%$ & Estadual & $\begin{array}{l}\text { Domingos João Baptista } \\
\text { Spinelli Professor Doutor }\end{array}$ & $32,0 \%$ \\
\hline Privada & Nossa Senhora Auxiliadora & $11,1 \%$ & Estadual & Djanira Velho Professora & $32,3 \%$ \\
\hline Privada & Marista & $11,3 \%$ & Estadual & Cid de Oliveira Leite & $32,8 \%$ \\
\hline Privada & Santa Úrsula Ribeirão Preto & $11,4 \%$ & Privada & $\begin{array}{l}\text { SESI } 344 \text { Centro } \\
\text { Educacional }\end{array}$ & $33,3 \%$ \\
\hline Privada & Vianna Colégio & $11,5 \%$ & Estadual & $\begin{array}{c}\text { Sebastião Fernandes Palma } \\
\text { Professor }\end{array}$ & $34,2 \%$ \\
\hline Privada & Gabarito Colégio & $12,2 \%$ & Estadual & $\begin{array}{l}\text { José Martimiano da Silva } \\
\text { ETEC }\end{array}$ & $37,0 \%$ \\
\hline Privada & Cervantes Colégio & $12,2 \%$ & Estadual & Walter Ferreira Professor & $37,1 \%$ \\
\hline Privada & $\begin{array}{c}\text { SESI } 362 \text { Centro } \\
\text { Educacional }\end{array}$ & $13,6 \%$ & Estadual & $\begin{array}{c}\text { Dr. Thomaz Alberto } \\
\text { Whately }\end{array}$ & $37,6 \%$ \\
\hline Privada & Espaço Cultural Colégio & $14,3 \%$ & Estadual & Otoniel Mota & $38,2 \%$ \\
\hline Privada & Brasil Colégio & $14,8 \%$ & Estadual & Romeu Alberti Dom & $39,4 \%$ \\
\hline Privada & Barão de Mauá & $15,7 \%$ & Estadual & Barros Cônego & $40,8 \%$ \\
\hline Privada & Ideal Colégio & $15,8 \%$ & Estadual & $\begin{array}{l}\text { Alberto José Goncalves } \\
\text { Dom } \\
\end{array}$ & $43,7 \%$ \\
\hline Privada & Moura Lacerda Colégio & $16,1 \%$ & Estadual & Alcides Correa Professor & $44,0 \%$ \\
\hline Privada & $\begin{array}{l}\text { Colégio Batista } \\
\text { Independente }\end{array}$ & $16,7 \%$ & Estadual & $\begin{array}{c}\text { Rafael Leme Franco } \\
\text { Professor } \\
\end{array}$ & $44,4 \%$ \\
\hline Privada & $\begin{array}{l}\text { Waldorf Joao Guimarães } \\
\text { Rosa Escola } \\
\end{array}$ & $16,7 \%$ & Estadual & Guimarães Júnior Doutor & $47,7 \%$ \\
\hline \multirow[t]{2}{*}{ Privada } & SESI 301 & $17,4 \%$ & Privada & SESI 346 & $50,0 \%$ \\
\hline & & & Estadual & Expedicionários Brasileiros & $60,0 \%$ \\
\hline
\end{tabular}

FONTE: INEP/MICRODADOS ENEM

Obs: Escolas com taxa de participação igual ou superior a 50\%.

A desigualdade de oportunidades educacionais no Brasil afeta de maneira diversa alunos de distintos grupos étnico raciais. Cabe sublinhar que distribuição desigual da renda no país está intrinsicamente relacionada com o impacto da questão racial na pobreza. Deste modo, as diferenças no perfil educacional de negros, pardos e brancos explicam as diferenças 
entre os desempenhos e trajetórias acadêmicas e mostram que a educação antevê a desigualdade de renda (FERREIRA; BARROS, 2000).

Como mostra a tabela 19, as escolas com percentual mais elevado em relação à presença de alunos negros no Ensino Médio participantes do ENEM 2015 concentram-se na rede pública estadual.

A escola pública Expedicionários Brasileiros apresentou a maior taxa de presença de alunos negros participantes do ENEM 2015, com 60\%. Abaixo, foto de um espaço de esporte e lazer comunitário danificado, nos fundos da escola.

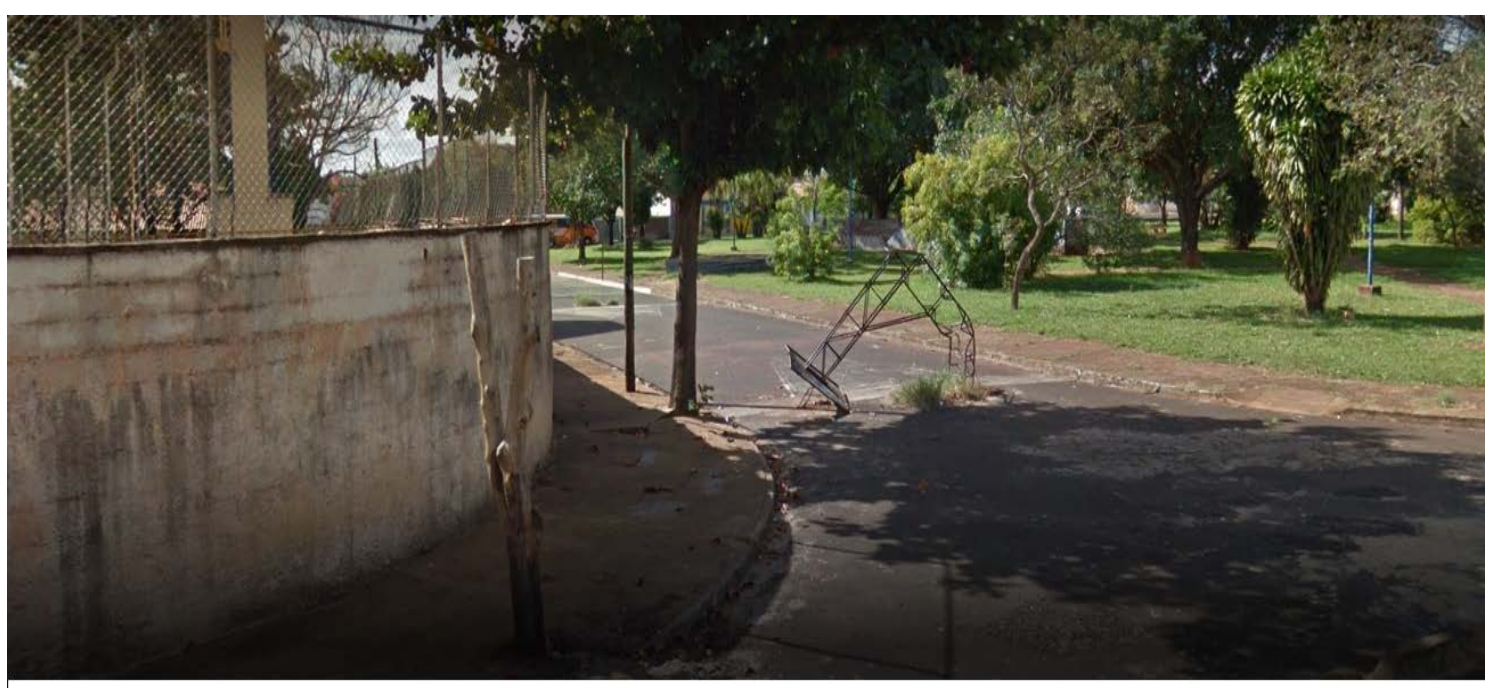

FONTE: GOOGLE MAPS

Estão também entre as escolas com maior percentual de negros matriculados participantes do ENEM 2015 as escolas estaduais Doutor Guimarães Júnior, Professor Rafael Leme Franco e Professor Alcides Correa, com respectivamente 47,7\%, 44,4\% e 44\%. A escola Doutor Guimarães Júnior, tem localização no Centro de Ribeirão Preto e Rafael Leme Franco e Alcides Correa estão localizadas em bairros não periféricos, o que requer um estudo mais pormenorizado sobre os perfis dos alunos e reprodução das desigualdades educacionais a partir do cenário social. O que costuma ocorrer com essas escolas, em especial as centrais, é que nelas não se encontram matriculados os filhos das famílias que habitam suas redondezas, seja pelo envelhecimento, seja pela possibilidade de pagar uma escola privada. 
Apresentam também percentuais expressivos quanto à presença de alunos negros as escolas da rede pública Dom Alberto José Gonçalves (43,7\%), Cônego Barros (40,8\%) e Dom Romeu Alberti (39,4\%).

Da rede privada, a escola SESI 346 apresentou 50\%, sendo a segunda maior porcentagem de negros da listagem total.

Cabe salientar algumas peculiaridades do SESI, como a oferta de serviços comunitários na aérea de cultura, esporte e saúde. As sete escolas SESI de Ribeirão Preto abarcam perfis de alunos muito próximos dos perfis de alunos da rede pública e sempre que o número de inscritos (não oriundos do Ensino Fundamental das próprias escolas SESI) no pleito por matrículas no Ensino Médio for maior que o número de vagas, os candidatos são submetidos a processo seleção. Cabe também comentar que as Escolas do SESI, que eram gratuitas, passaram a cobrar mensalidades há mais de uma década, o que leva a uma maior seletividade econômica, até porque a participação do setor industrial (pública inicial dessa escolas) é muito incipiente.

O menor percentual de alunos negros matriculados entre as escolas públicas é de 18,4\% da escola estadual Doutor Joao Palma Guião, localizada na periferia da zona norte da cidade, conhecida pela alta densidade demográfica e criminalidade. Entre os menores percentuais também estão as escolas estaduais Doutor Francisco da Cunha Junqueira, situada no Distrito de Bomfim (que está se tornando uma região de condomínios de classe média alta), com 22\% e Miguel Jorge com 22,5\%, esta última situada em uma região de classe média e que tem pouco contato com outros bairros em função de obstáculos naturais..

Três escolas da rede privada, conforme indica a tabela, não indicaram a presença de alunos negros participantes do ENEM. São: Colégio Anchieta, Liceu Samuel Pfromm Netto e Escola Castelo; e entre os menores percentuais de alunos negros nas escolas particulares o Colégio Einstein lidera com apenas 4,2\% de alunos negros, seguido do SEB COC Alvares Cabral com $4,3 \%$ e FAAP com $5,7 \%$.

Na Tabela 21 foram levantados dados da escolaridade das mães dos participantes e dependência administrativa 
TABELA 21 - PERCENTUAL DE MÃES DE ALUNOS PARTICIPANTES DO ENEM 2015 QUE CONCLUÍRAM A EDUCAÇÃO SUPERIOR POR DEPENDÊNCIA ADMINISTRATIVA

\begin{tabular}{|c|c|c|c|c|c|}
\hline $\begin{array}{l}\text { Dep. } \\
\text { Adm }\end{array}$ & Escola & $\begin{array}{l}\text { \% mães } \\
\text { com Ed. } \\
\text { Superior } \\
\end{array}$ & $\begin{array}{l}\text { Dep. } \\
\text { Adm }\end{array}$ & Escola & $\begin{array}{l}\text { \% mães } \\
\text { com Ed. } \\
\text { Superior }\end{array}$ \\
\hline Privada & $\begin{array}{l}\text { Waldorf João Guimarães } \\
\text { Rosa Escola }\end{array}$ & $91,7 \%$ & Privada & Cervantes Colégio & $22,4 \%$ \\
\hline Privada & $\begin{array}{c}\text { SEB COC Unidade Álvares } \\
\text { Cabral }\end{array}$ & $87,0 \%$ & Privada & Brasil Colégio & $22,2 \%$ \\
\hline Privada & Einstein Colégio & $86,4 \%$ & Privada & $\begin{array}{l}\text { SESI } 298 \text { Centro } \\
\text { Educacional }\end{array}$ & $21,4 \%$ \\
\hline Privada & $\begin{array}{l}\text { FAAP Ribeirão Preto } \\
\text { Colégio }\end{array}$ & $76,4 \%$ & Privada & $\begin{array}{c}\text { SESI } 301 \text { Centro } \\
\text { Educacional }\end{array}$ & $17,4 \%$ \\
\hline Privada & $\begin{array}{l}\text { Albert Sabin Escola de } \\
\text { Ensino Médio }\end{array}$ & $68,9 \%$ & Estadual & $\begin{array}{c}\text { Cid de Oliveira Leite } \\
\text { Professor }\end{array}$ & $17,2 \%$ \\
\hline Privada & $\begin{array}{c}\text { SEB COC Unidade } \\
\text { Lafaiete }\end{array}$ & $66,0 \%$ & Privada & Samuel Pfromm Netto Liceu & $16,7 \%$ \\
\hline Privada & $\begin{array}{c}\text { Santa Úrsula Ribeirão Preto } \\
\text { Ed. Infantil, Ensino } \\
\text { Fundamental e Médio } \\
\end{array}$ & $60,0 \%$ & Privada & $\begin{array}{l}\text { SESI } 259 \text { Centro } \\
\text { Educacional }\end{array}$ & $16,0 \%$ \\
\hline Privada & Gabarito Colégio & $59,2 \%$ & Estadual & $\begin{array}{c}\text { Jose Martimiano da Silva } \\
\text { ETEC }\end{array}$ & $14,8 \%$ \\
\hline Privada & $\begin{array}{l}\text { Marista Colégio de } \\
\text { Ribeirão Preto }\end{array}$ & $58,5 \%$ & Privada & $\begin{array}{c}\text { Adventista de Ribeiro Preto } \\
\text { Colégio }\end{array}$ & $14,3 \%$ \\
\hline Privada & $\begin{array}{c}\text { Carlos Chagas Filho Escola } \\
\text { Ensino Fundamental e } \\
\text { Médio } \\
\end{array}$ & $55,8 \%$ & Estadual & $\begin{array}{c}\text { Sebastião Fernandes Palma } \\
\text { Professor }\end{array}$ & $14,0 \%$ \\
\hline Privada & $\begin{array}{l}\text { Castelo Escola Ed. Infantil } \\
\text { e Ensino Fundamental }\end{array}$ & $55,6 \%$ & Estadual & Miguel Jorge & $13,5 \%$ \\
\hline Privada & $\begin{array}{c}\text { Viktor Frankl Colégio } \\
\text { Ensino Médio } \\
\end{array}$ & $52,6 \%$ & Estadual & $\begin{array}{l}\text { Francisco da Cunha } \\
\text { Junqueira Doutor }\end{array}$ & $12,2 \%$ \\
\hline Privada & $\begin{array}{c}\text { Nossa Senhora Auxiliadora } \\
\text { Colégio }\end{array}$ & $51,9 \%$ & Estadual & Romeu Alberti Dom & $12,1 \%$ \\
\hline Privada & $\begin{array}{l}\text { Barão de Mauá Ed. } \\
\text { Infantil, Ensino } \\
\text { Fundamental e Médio }\end{array}$ & $51,4 \%$ & Privada & $\begin{array}{l}\text { SESI } 345 \text { Centro } \\
\text { Educacional }\end{array}$ & $10,0 \%$ \\
\hline Privada & $\begin{array}{c}\text { Colégio Batista } \\
\text { Independente de Ribeirão } \\
\text { Preto } \\
\end{array}$ & $50,0 \%$ & Estadual & Djanira Velho Professora & $9,7 \%$ \\
\hline Privada & $\begin{array}{l}\text { Ressurreição Vita Et Pax } \\
\text { Colégio } \\
\end{array}$ & $50,0 \%$ & Estadual & Otoniel Mota & $9,3 \%$ \\
\hline Privada & Carlos Magno Colégio & $50,0 \%$ & Estadual & Alcides Correa Professor & $8,0 \%$ \\
\hline Privada & $\begin{array}{l}\text { Iavec Vida de Ensino } \\
\text { Cristão }\end{array}$ & $46,2 \%$ & Estadual & $\begin{array}{l}\text { Prof. Domingos João } \\
\text { Baptista Spinelli }\end{array}$ & $8,0 \%$ \\
\hline Privada & $\begin{array}{l}\text { Liceu Contemporâneo } \\
\text { Ensino Médio } \\
\end{array}$ & $44,4 \%$ & Estadual & João Palma Guião Doutor & $7,9 \%$ \\
\hline Privada & $\begin{array}{l}\text { Metodista de Ribeirão Preto } \\
\text { Colégio } \\
\end{array}$ & $44,0 \%$ & Privada & $\begin{array}{c}\text { SESI } 346 \text { Centro } \\
\text { Educacional }\end{array}$ & $7,7 \%$ \\
\hline Privada & Espaço Cultural Colégio & $42,9 \%$ & Estadual & $\begin{array}{c}\text { Rafael Leme Franco } \\
\text { Professor }\end{array}$ & $7,4 \%$ \\
\hline Privada & Ideal Colégio & $42,1 \%$ & Privada & $\begin{array}{c}\text { SESI } 297 \text { Centro } \\
\text { Educacional } \\
\end{array}$ & $7,1 \%$ \\
\hline Privada & $\begin{array}{c}\text { Objetivo Centro } \\
\text { Interescolar Unidade }\end{array}$ & $41,0 \%$ & Estadual & $\begin{array}{c}\text { Dr. Thomaz Alberto } \\
\text { Whately }\end{array}$ & $6,6 \%$ \\
\hline Privada & $\begin{array}{c}\text { Moura Lacerda Colégio } \\
\text { Unidade I } \\
\end{array}$ & $38,7 \%$ & Estadual & Barros Cônego & $5,4 \%$ \\
\hline
\end{tabular}




\begin{tabular}{c|c|c|c|c|c}
\hline Privada & $\begin{array}{c}\text { Lacordaire Colégio Ensino } \\
\text { Médio }\end{array}$ & $37,5 \%$ & Estadual & Alberto Santos Dumont & $5,3 \%$ \\
\hline & $\begin{array}{c}\text { Almeida Garrett Escola } \\
\text { Ensino Fundamental e } \\
\text { Privada }\end{array}$ & $\begin{array}{c}36,0 \% \\
\text { Privada }\end{array}$ & Estadual & Walter Ferreira Professor & $4,8 \%$ \\
\hline Privada & Vianna Colégio & $30,8 \%$ & Estadual & Alberto Jose Goncalves & Dom \\
\hline Privada & $\begin{array}{c}\text { SESI 344 Centro } \\
\text { Educacional }\end{array}$ & $27,8 \%$ & Privada & $\begin{array}{c}\text { SESI 362 Centro } \\
\text { Educacional }\end{array}$ & $1,9 \%$ \\
\hline Privada & Cervantes Colégio & $22,4 \%$ & Estadual & Expedicionários Brasileiros & $0,0 \%$ \\
\hline
\end{tabular}

FONTE: INEP/MICRODADOS ENEM

Obs: Escolas com taxa de participação igual ou superior a 50\%.

A Escola Waldorf Guimarães Rosa entre todas as escolas é a que apresenta maior porcentagem de mães que concluíram curso superior com 91,7\%, seguidas do SEB COC Unidade Alvares Cabral e Colégio Einstein, com 87\% e 86,4\% respectivamente.

Entre as escolas com percentual mais expressivo em relação à escolaridade das mães, a escola Waldorf Guimarães Rosa é a única que não pertenceu ao grupo que liderou o ranking do EMEM 2015 na cidade de Ribeirão Preto.

A cosmovisão antroposófica, na qual a Pedagogia Waldorf se insere, opõem- se à visão de homem tradicional e o pensamento intuitivo adquirido pela autorreflexão é responsável pelo desenvolvimento individual (ROMANELLI, 2015). Pode-se afirmar que os princípios holísticos que envolvem a Pedagogia Waldorf se distanciam da competitividade mercadológica tão presente no rankeamento das notas do ENEM. Assim, não obstante o elevado capital cultural, o projeto pedagógico não voltado à preparação para o vestibular e a expectativa diferenciada dos pais parece indicar o perfil de desempenho dos estudantes oriundos dessa escola.

A escola privada SESI 362 e a escola estadual Expedicionários Brasileiros não indicaram percentuais que demonstrem a presença de mães que cursaram a Educação Superior, salientando que a estadual Expedicionários teve a pior nota média do exame de 2015. Por conseguinte, seguem entre as menores faixas de escolaridade as escolas públicas Dom Alberto José Gonçalves (1,9\%) e Doutor Guimarães Júnior (4,7\%), lembrando que esta apresentou a sexta mais baixa proficiência média do município nesta edição do exame.

Entre as escolas privadas, exceto as unidades SESI (que compactuam com perfis de alunos muito aproximados com os da escola pública e concede um percentual significativo de bolsas, conforme será tratado adiante), o Colégio Adventista de Ribeirão Preto aponta o 
menor percentual de mães com nível superior de escolaridade de 14,3\%, seguido do Liceu Samuel Pfromm Netto, com 16,7\% e Colégio Brasil, com 22,2\%.

Os níveis mais baixos quanto à escolaridade das mães da rede privada remetem à análise anterior sobre suas ocupações, que estão diretamente relacionadas com a faixa de renda e possibilidades de custeio das mensalidades em colégios de Ensino Médio de menor prestígio e que obtêm médias no ENEM proximais às médias das escolas públicas, como no caso da escola Espaço Cultural onde 42,9\% das mães concluíram a Educação Superior e possui a quarta pior proficiência média, como será contatado adiante.

As Tabelas 22 e 23 apontam a média geral de desempenho no ENEM 2015 distribuídas entre os tipos de dependência administrativa, número de participantes no ENEM 2015, taxas de escolaridade da mãe, percentual de alunos negros, faixas de renda mensal, e participantes que indicaram exercício de atividade remunerada.

Os dados foram divididos em duas tabelas de diferentes faixas de proficiência para auxiliar a visualização.

TABELA 22 - MÉDIA GERAL DE DESEMPENHO POR ESCOLA, CONSIDERANDO No PARTICIPANTES NO ENEM 2015, PARTICIPAÇÃO DE NEGROS, MÃES COM EDUCAÇÃO SUPERIOR, RENDA, EXERCÍCIO DE ATIVIDADE REMUNERADA E BOLSISTAS NA REDE PRIVADA (PARTE 1: MÉDIA ACIMA DE 550)

\begin{tabular}{c|c|c|c|c|c|c|c|c|c}
\hline $\begin{array}{c}\text { Média } \\
\text { Geral }\end{array}$ & Escola & $\begin{array}{c}\text { Dep. } \\
\text { Adm }\end{array}$ & $\mathbf{N}^{\mathbf{2}}$ & $\begin{array}{c}\text { Mães } \\
\text { com Ed. } \\
\text { Superior }\end{array}$ & Negros & $\begin{array}{c}\text { Renda } \\
\text { acima } \\
\text { de R\$.092,01 }\end{array}$ & $\begin{array}{c}\text { Renda } \\
\text { abaixo } \\
\text { de R\$.572,00 } \\
\mathbf{1}\end{array}$ & $\begin{array}{c}\text { Atividade } \\
\text { remu- } \\
\text { nerada }\end{array}$ & $\begin{array}{c}\text { Alunos } \\
\text { com } \\
\text { bolsa }\end{array}$ \\
\hline 702 & $\begin{array}{c}\text { SEB COC Unidade } \\
\text { Álvares Cabral }\end{array}$ & Privada & 46 & $87,0 \%$ & $4,3 \%$ & $69,6 \%$ & $0,0 \%$ & $0,0 \%$ & $8,7 \%$ \\
\hline 670 & FAAP & Privada & 174 & $76,4 \%$ & $5,7 \%$ & $59,8 \%$ & $1,7 \%$ & $0,6 \%$ & $9,2 \%$ \\
\hline 635 & Albert Sabin & Privada & 228 & $68,9 \%$ & $6,6 \%$ & $54,4 \%$ & $3,5 \%$ & $2,6 \%$ & $9,2 \%$ \\
\hline 634 & $\begin{array}{c}\text { SEB COC Unidade } \\
\text { Lafaiete }\end{array}$ & Privada & 421 & $66,0 \%$ & $6,4 \%$ & $43,7 \%$ & $3,8 \%$ & $1,9 \%$ & $11,9 \%$ \\
\hline 633 & Einstein Colégio & Privada & 118 & $86,4 \%$ & $4,2 \%$ & $83,1 \%$ & $0,8 \%$ & $1,7 \%$ & $3,4 \%$ \\
\hline 630 & Marista & Privada & 53 & $58,5 \%$ & $11,3 \%$ & $39,6 \%$ & $1,9 \%$ & $0,0 \%$ & $17,0 \%$ \\
\hline 617 & Gabarito Colégio & Privada & 49 & $59,2 \%$ & $12,2 \%$ & $36,7 \%$ & $6,1 \%$ & $2,0 \%$ & $14,3 \%$ \\
\hline 614 & Ideal Colégio & Privada & 19 & $42,1 \%$ & $15,8 \%$ & $31,6 \%$ & $0,0 \%$ & $5,3 \%$ & $15,8 \%$ \\
\hline 609 & Santa Úrsula & Privada & 70 & $60,0 \%$ & $11,4 \%$ & $31,4 \%$ & $8,6 \%$ & $0,0 \%$ & $32,9 \%$ \\
\hline 600 & $\begin{array}{c}\text { Nossa Senhora } \\
\text { Auxiliadora }\end{array}$ & Privada & 27 & $51,9 \%$ & $11,1 \%$ & $18,5 \%$ & $11,1 \%$ & $3,7 \%$ & $40,7 \%$ \\
\hline 599 & $\begin{array}{c}\text { Colégio Batista } \\
\text { Independente }\end{array}$ & Privada & 6 & $50,0 \%$ & $16,7 \%$ & $16,7 \%$ & $33,3 \%$ & $0,0 \%$ & $16,7 \%$ \\
\hline 599 & Lacordaire & Privada & 32 & $37,5 \%$ & $31,3 \%$ & $31,3 \%$ & $6,3 \%$ & $0,0 \%$ & $3,1 \%$ \\
\hline 597 & $\begin{array}{c}\text { Objetivo Unidade } \\
\text { XXVII }\end{array}$ & Privada & 39 & $41,0 \%$ & $7,7 \%$ & $17,9 \%$ & $10,3 \%$ & $0,0 \%$ & $25,6 \%$ \\
\hline
\end{tabular}




\begin{tabular}{|c|c|c|c|c|c|c|c|c|c|}
\hline 579 & $\begin{array}{c}\text { SESI } 298 \text { Centro } \\
\text { Educacional } \\
\end{array}$ & Privada & 28 & $21,4 \%$ & $7,1 \%$ & $7,1 \%$ & $14,3 \%$ & $10,7 \%$ & $25,0 \%$ \\
\hline 578 & $\begin{array}{c}\text { Iavec Vida de } \\
\text { Ensino Cristão } \\
\text { Instituto Avançado }\end{array}$ & Privada & 13 & $46,2 \%$ & $23,1 \%$ & $23,1 \%$ & $0,0 \%$ & $15,4 \%$ & $7,7 \%$ \\
\hline 576 & $\begin{array}{l}\text { Samuel Pfromm } \\
\text { Netto Liceu }\end{array}$ & Privada & 6 & $16,7 \%$ & $0,0 \%$ & $0,0 \%$ & $0,0 \%$ & $33,3 \%$ & $0,0 \%$ \\
\hline 573 & $\begin{array}{l}\text { Adventista de } \\
\text { Ribeiro Preto } \\
\text { Colégio } \\
\end{array}$ & Privada & 35 & $14,3 \%$ & $28,6 \%$ & $8,6 \%$ & $17,1 \%$ & $14,3 \%$ & $17,1 \%$ \\
\hline 569 & Vianna Colégio & Privada & 26 & $30,8 \%$ & $11,5 \%$ & $15,4 \%$ & $0,0 \%$ & $7,7 \%$ & $3,8 \%$ \\
\hline 569 & $\begin{array}{l}\text { Carlos Chagas } \\
\text { Filho Escola } \\
\end{array}$ & Privada & 52 & $55,8 \%$ & $7,7 \%$ & $26,9 \%$ & $5,8 \%$ & $5,8 \%$ & $13,5 \%$ \\
\hline 568 & SESI 345 & Privada & 30 & $10,0 \%$ & $23,3 \%$ & $3,3 \%$ & $33,3 \%$ & $6,7 \%$ & $26,7 \%$ \\
\hline 567 & $\begin{array}{l}\text { Almeida Garrett } \\
\text { Escola } \\
\end{array}$ & Privada & 25 & $36,0 \%$ & $20,0 \%$ & $0,0 \%$ & $16,0 \%$ & $0,0 \%$ & $36,0 \%$ \\
\hline 566 & SESI 297 & Privada & 28 & $7,1 \%$ & $28,6 \%$ & $3,6 \%$ & $28,6 \%$ & $3,6 \%$ & $39,3 \%$ \\
\hline 565 & $\begin{array}{c}\text { Jose Martimiano da } \\
\text { Silva ETEC } \\
\end{array}$ & Estadual & 27 & $14,8 \%$ & $37,0 \%$ & $3,7 \%$ & $37,0 \%$ & $3,7 \%$ & $0,0 \%$ \\
\hline 565 & Barão de Mauá & Privada & 70 & $51,4 \%$ & $15,7 \%$ & $20,0 \%$ & $4,3 \%$ & $8,6 \%$ & $8,6 \%$ \\
\hline 563 & $\begin{array}{c}\text { Liceu } \\
\text { Contemporâneo }\end{array}$ & Privada & 27 & $44,4 \%$ & $7,4 \%$ & $11,1 \%$ & $18,5 \%$ & $11,1 \%$ & $7,4 \%$ \\
\hline 557 & $\begin{array}{c}\text { SESI } 344 \text { Centro } \\
\text { Educacional }\end{array}$ & Privada & 18 & $27,8 \%$ & $33,3 \%$ & $0,0 \%$ & $27,8 \%$ & $22,2 \%$ & $50,0 \%$ \\
\hline 555 & SESI 301 & Privada & 23 & $17,4 \%$ & $17,4 \%$ & $4,3 \%$ & $21,7 \%$ & $13,0 \%$ & $26,1 \%$ \\
\hline 554 & Metodista & Privada & 50 & $44,0 \%$ & $26,0 \%$ & $24,0 \%$ & $10,0 \%$ & $2,0 \%$ & $16,0 \%$ \\
\hline
\end{tabular}

FONTE: INEP/MICRODADOS ENEM

TABELA 23 - MÉDIA GERAL DE DESEMPENHO POR ESCOLA, CONSIDERANDO O NÚMERO DE PARTICIPANTES NO ENEM 2015, PARTICIPAÇÃO DE NEGROS, MÃES COM EDUCAÇÃO SUPERIOR, RENDA, EXERCÍCIO DE ATIVIDADE REMUNERADA E PERCENTUAL DE BOLSISTAS NA REDE PRIVADA (PARTE 2: MÉDIA ABAIXO DE 550)

\begin{tabular}{|c|c|c|c|c|c|c|c|c|c|}
\hline $\begin{array}{l}\text { Média } \\
\text { Geral } \\
\end{array}$ & Escola & $\begin{array}{l}\text { Dep. } \\
\text { Adm }\end{array}$ & $\mathbf{N}^{\mathbf{0}}$ & $\begin{array}{c}\text { Mães } \\
\text { com Ed. } \\
\text { Superior } \\
\end{array}$ & Negros & 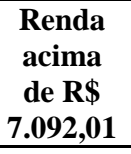 & 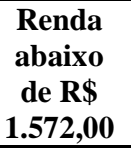 & $\begin{array}{c}\text { Atividad } \\
\text { e remu- } \\
\text { nerada }\end{array}$ & $\begin{array}{c}\text { Alunos } \\
\text { com } \\
\text { bolsa }\end{array}$ \\
\hline 547 & $\begin{array}{c}\text { Waldorf João } \\
\text { Guimarães Rosa } \\
\end{array}$ & Privada & 12 & $91,7 \%$ & $16,7 \%$ & $41,7 \%$ & $0,0 \%$ & $0,0 \%$ & $41,7 \%$ \\
\hline 547 & Vita Et Pax & Privada & 12 & $50,0 \%$ & $25,0 \%$ & $16,7 \%$ & $0,0 \%$ & $16,7 \%$ & $8,3 \%$ \\
\hline 537 & SESI 259 & Privada & 25 & $16,0 \%$ & $24,0 \%$ & $0,0 \%$ & $28,0 \%$ & $12,0 \%$ & $16,0 \%$ \\
\hline 536 & Cervantes Colégio & Privada & 49 & $22,4 \%$ & $12,2 \%$ & $10,2 \%$ & $10,2 \%$ & $12,2 \%$ & $8,2 \%$ \\
\hline 536 & $\begin{array}{c}\text { Moura Lacerda } \\
\text { Colégio Unidade I } \\
\end{array}$ & Privada & 31 & $38,7 \%$ & $16,1 \%$ & $6,5 \%$ & $6,5 \%$ & $16,1 \%$ & $9,7 \%$ \\
\hline 530 & SESI 346 & Privada & 26 & $7,7 \%$ & $50,0 \%$ & $0,0 \%$ & $23,1 \%$ & $15,4 \%$ & $34,6 \%$ \\
\hline 530 & Brasil Colégio & Privada & 27 & $22,2 \%$ & $14,8 \%$ & $7,4 \%$ & $22,2 \%$ & $3,7 \%$ & $18,5 \%$ \\
\hline 524 & Walter Ferreira & Estadual & 62 & $4,8 \%$ & $37,1 \%$ & $1,6 \%$ & $41,9 \%$ & $19,4 \%$ & $0,0 \%$ \\
\hline 521 & Carlos Magno & Privada & 14 & $50,0 \%$ & $7,1 \%$ & $21,4 \%$ & $0,0 \%$ & $21,4 \%$ & $0,0 \%$ \\
\hline 517 & SESI 362 & Privada & 22 & $0,0 \%$ & $13,6 \%$ & $0,0 \%$ & $36,4 \%$ & $22,7 \%$ & $36,4 \%$ \\
\hline 514 & Barros Cônego & Estadual & 184 & $5,4 \%$ & $40,8 \%$ & $1,6 \%$ & $40,2 \%$ & $26,6 \%$ & $0,0 \%$ \\
\hline 512 & Djanira Velho & Estadual & 93 & $9,7 \%$ & $32,3 \%$ & $0 \%$ & $41,9 \%$ & $19,4 \%$ & $0,0 \%$ \\
\hline 510 & $\begin{array}{l}\text { Cid de Oliveira } \\
\text { Leite Professor } \\
\end{array}$ & Estadual & 250 & $17,2 \%$ & $32,8 \%$ & $4,4 \%$ & $36,8 \%$ & $24,4 \%$ & $0,0 \%$ \\
\hline 509 & Romeu Alberti Dom & Estadual & 99 & $12,1 \%$ & $39,4 \%$ & $1,0 \%$ & $28,3 \%$ & $27,3 \%$ & $0,0 \%$ \\
\hline 509 & Sebastião Fernandes & Estadual & 114 & $14,0 \%$ & $34,2 \%$ & $0,9 \%$ & $31,6 \%$ & $22,8 \%$ & $0,0 \%$ \\
\hline
\end{tabular}




\begin{tabular}{|c|c|c|c|c|c|c|c|c|c|}
\hline & Palma Professor & & & & & & & & \\
\hline 508 & Rafael Leme Franco & Estadual & 27 & $7,4 \%$ & $44,4 \%$ & $0,0 \%$ & $44,4 \%$ & $25,9 \%$ & $0,0 \%$ \\
\hline 508 & $\begin{array}{c}\text { Alberto Santos } \\
\text { Dumont } \\
\end{array}$ & Estadual & 133 & $5,3 \%$ & $29,3 \%$ & $2,3 \%$ & $32,3 \%$ & $21,1 \%$ & $0,0 \%$ \\
\hline 508 & Otoniel Mota & Estadual & 421 & $9,3 \%$ & $38,2 \%$ & $1,2 \%$ & $47,0 \%$ & $35,4 \%$ & $0,0 \%$ \\
\hline 506 & Alcides Correa & Estadual & 50 & $8,0 \%$ & $44,0 \%$ & $2,0 \%$ & $28,0 \%$ & $36,0 \%$ & $0,0 \%$ \\
\hline 499 & $\begin{array}{c}\text { Francisco da Cunha } \\
\text { Junqueira Doutor }\end{array}$ & Estadual & 41 & $12,2 \%$ & $22,0 \%$ & $0,0 \%$ & $39,0 \%$ & $46,3 \%$ & $0,0 \%$ \\
\hline 498 & $\begin{array}{c}\text { Dr. Thomaz Alberto } \\
\text { Whately }\end{array}$ & Estadual & 271 & $6,6 \%$ & $37,6 \%$ & $1,5 \%$ & $40,6 \%$ & $32,5 \%$ & $0,0 \%$ \\
\hline 498 & Castelo Escola & Privada & 9 & $55,6 \%$ & $0,0 \%$ & $44,4 \%$ & $11,1 \%$ & $0,0 \%$ & $0,0 \%$ \\
\hline 494 & $\begin{array}{l}\text { João Palma Guião } \\
\text { Doutor } \\
\end{array}$ & Estadual & 38 & $7,9 \%$ & $18,4 \%$ & $0,0 \%$ & $55,3 \%$ & $15,8 \%$ & $0,0 \%$ \\
\hline 492 & Guimarães Junior & Estadual & 86 & $4,7 \%$ & $47,7 \%$ & $0,0 \%$ & $58,1 \%$ & $26,7 \%$ & $0,0 \%$ \\
\hline 492 & Miguel Jorge & Estadual & 89 & $13,5 \%$ & $22,5 \%$ & $2,2 \%$ & $38,2 \%$ & $38,2 \%$ & $0,0 \%$ \\
\hline 489 & $\begin{array}{c}\text { Espaço Cultural } \\
\text { Colégio } \\
\end{array}$ & Privada & 7 & $42,9 \%$ & $14,3 \%$ & $14,3 \%$ & $0,0 \%$ & $28,6 \%$ & $0,0 \%$ \\
\hline 484 & $\begin{array}{c}\text { Domingos Joao } \\
\text { Baptista Spinelli } \\
\text { Professor } \\
\end{array}$ & Estadual & 25 & $8,0 \%$ & $32,0 \%$ & $0,0 \%$ & $56,0 \%$ & $24,0 \%$ & $0,0 \%$ \\
\hline 481 & $\begin{array}{c}\text { Alberto Jose } \\
\text { Gonçalves Dom }\end{array}$ & Estadual & 103 & $1,9 \%$ & $43,7 \%$ & $1,0 \%$ & $49,5 \%$ & $31,1 \%$ & $0,0 \%$ \\
\hline 472 & $\begin{array}{c}\text { Expedicionários } \\
\text { Brasileiros } \\
\end{array}$ & Estadual & 15 & $0,0 \%$ & $60,0 \%$ & $0,0 \%$ & $6,7 \%$ & $46,7 \%$ & $0,0 \%$ \\
\hline
\end{tabular}

FONTE: INEP/MICRODADOS ENEM

Para prosseguir na análise foram destacados inicialmente dois blocos de escolas de acordo com a colocação (média geral) no ranking do desempenho no ENEM 2015, partindo dos dois extremos das posições. Desses colégios, serão analisadas as variáveis acima indicadas a fim de delinear os perfis das escolas participantes do exame que integraram a lista de escores. Eventualmente foram observadas escolas não integrantes dos dois blocos definidos pelo desempenho em resposta às características que emergiram das variáveis e evocam alguma discussão.

No bloco 1 estão as escolas (em ordem decrescente) de pontuação que alcançaram as mais altas médias de proficiência, indicadas na lista que corresponde à Tabela 22:

1. SEB COC - Unidade Alvares Cabral (privada)

2.FAAP (privada)

3. Liceu Albert Sabin (privada)

4. SEB COC - Unidade Lafaiete (privada)

5. Colégio Einstein (privada)

A unidade Alvares Cabral do SEB COC obteve média geral igual a 702 pontos, também a maior participação no exame com 46 alunos, onde 8,7\% eram bolsistas. Tem o segundo maior percentual de mães que concluíram a Educação Superior (87,0\%), o quarto menor percentual de alunos negros (4,3\%), e a segunda maior porcentagem $(69,6 \%)$ de 
declarantes de renda acima de R 7.092,01 mensais. Ninguém indicou renda abaixo de R\$ 1.572,00 e nenhum aluno declarou exercer atividade remunerada.

É válido ressaltar que a unidade Álvares Cabral do SEB COC reúne alunos que se dedicam integralmente aos vestibulares para as carreiras mais concorridas, e que algumas instituições de ensino valorizadas pelos rankings do ENEM utilizavam os resultados do exame como uma vitrine atrativa de novas matrículas. Grandes redes de ensino privado, como o SEB COC que se constituem e autodenominam-se "sistemas de ensino" reunindo os alunos de melhor performance em uma nova unidade escolar sob outro CNPJ. Os alunos de alto rendimento são em grande parte oriundos de outras escolas e atraídos pela concessão de bolsas e descontos nas mensalidades em troca de sua dedicação. É forjada a criação de nova pessoa jurídica tratando-se do mesmo grupo empresarial que debita do mérito individual a crença incauta na qualidade da escola privada, como é possível constatar na análise de perfil da quarta colocada do bloco 1, SEB COC - Unidade Lafaiete com localização descrita na Imagem 3 abaixo.

\section{IMAGEM 3 - MAPA DO PERCURSO DA UNIDADE LAFAIETE À UNIDADE ALVARES CABRAL}

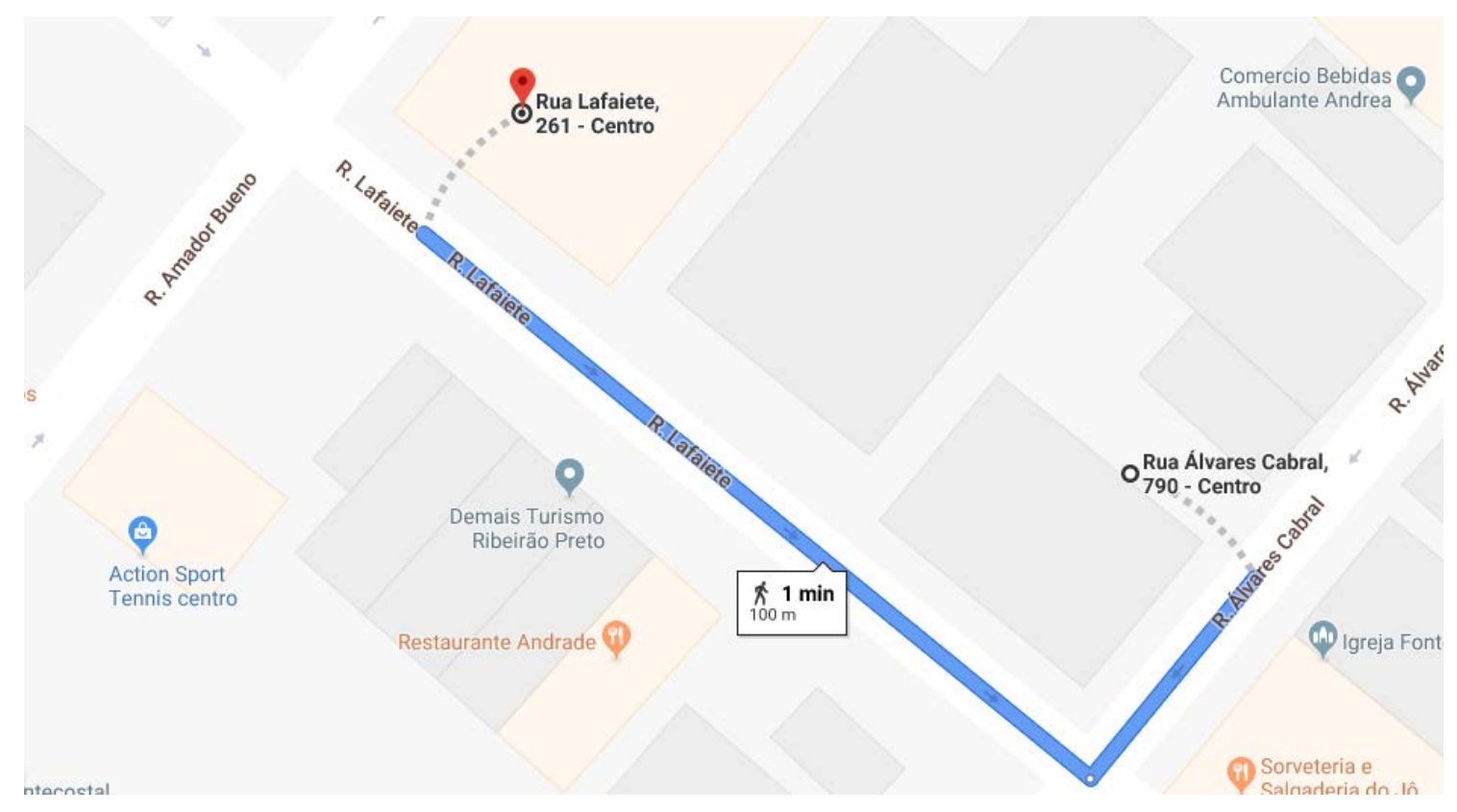

FONTE: GOOGLE MAPS

A escola SEB COC Unidade Lafaiete, quarta colocada no ranking, tem endereço na Rua Lafaiete, número 261, e a Unidade Alvares Cabral na Rua Alvares Cabral, número 790, sendo as duas pertencentes ao mesmo complexo predial, mas sob inscrição de dois números de CNPJ. 
A segunda maior pontuação foi de 670 pontos do Colégio FAAP com 174 alunos participantes do ENEM 2015, onde 9,2\% eram bolsistas e 5,7\% declarados negros. 76,4\% das mães concluíram a Educação Superior. Informaram faixa de renda mensal acima de R\$ 7.092,01 mensais. 1,7\% declararam renda abaixo de $\mathrm{R} \$ 1.572,00$ e nenhum aluno declarou exercer atividade remunerada.

O Liceu Albert Sabin obteve a terceira maior pontuação média com 635 pontos com seus 228 alunos participantes do exame e oferta de 9,2\% de bolsas de estudos. 68,9\%, segundo os declarantes tem mãe com curso superior completo. Indicaram faixa de renda acima de $\mathrm{R} \$$ 7.092,01 mensais 54,4\% e abaixo de $\mathrm{R} \$$ 1.572,00 3,5\% dos participantes. 2,6\% dos alunos participantes afirmaram exercer atividade remunerada no período do ENEM 2015.

A Unidade Lafaiete do SEB COC, como já comentado, teve a quarta maior pontuação média com 634 pontos na prova e contou com 421 participantes, o maior número de alunos da lista que também equivale ao número de participantes da Escola Estadual Otoniel Mota, conhecida durante as ocupações dos estudantes secundaristas de 2015.

Para fins de comparação, a Unidade Alavares Cabral, a de maior nota, contou com apenas 46 participantes, o que remete à segregação dos alunos de melhor performance e perfis mais privilegiados em unidade distinta do mesmo grupo empresarial. Na unidade SEB COC Lafaiete, 66\% das mães, segundo os declarantes, terminaram um curso superior. 6,4\% dos alunos participantes declararam-se negros e a oferta de bolsas entre os participantes do ENEM 2015 foi de 11,9\%, o maior percentual de concessão do bloco de “elite”. 43,7\% indicaram renda mensal superior à $\mathrm{R} \$ 7.092,01$ e 3,8\% abaixo de $\mathrm{R} \$ 1.572,00$. 1,9\% dos participantes exerciam atividade remunerada.

O Colégio Einstein obteve média de 633 pontos e contou com a participação de 118 alunos, dos quais apenas 3,4\% cursaram o terceiro ano com bolsa de estudos e 4,2\% declararam-se negros (segundo menor percentual). 86,4\% das mães dos alunos participantes do ENEM 2015 completaram a Educação Superior (terceiro maior índice). O Colégio Einstein tem a primeira posição quanto ao percentual de alunos que declararam renda mensal acima de R\$ 7.092,01, com 83,1\%. Apenas 0,8\% declararam renda mensal inferior à R\$ 1.572,00 e 1,7\% dos participantes eram trabalhadores à época do exame de 2015.

Determinantes comuns entre pontuações, contextos socioeconômicos e fatores de origem confluem para o desenho do perfil de liderança dos rankings do ENEM. Em geral, são escolas com público branco de alta renda, alunos que não trabalham, famílias com maior nível de escolaridade e baixa oferta de bolsas, por vezes condicionadas a agregar alunos "fortes” da rede pública. 
A respeito dos maiores percentuais de concessão de bolsas de estudos é preciso recorrer à análise da natureza jurídica de cada instituição. O Art. 20 da LDB (Lei 9.394/96) classifica as escolas não estatais em: I - particulares em sentido estrito, entendidas como as instituídas e mantidas por uma ou mais pessoas físicas ou jurídicas de direito privado que não apresentem as características das comunitárias, confessionais e filantrópicas; II comunitárias, entendidas como as instituídas por grupos de pessoas físicas ou por uma ou mais pessoas jurídicas, inclusive cooperativas de professores e alunos que incluam na sua entidade mantenedora representantes da comunidade; III - confessionais, entendidas como as instituídas por grupos de pessoas físicas ou por uma ou mais pessoas jurídicas que atendam a orientação confessional e ideológica específicas e ao disposto no inciso anterior; IV filantrópicas, na forma da lei.

Segundo o Art. 32, inciso I do Decreto de Lei N $^{\circ}$ 8.242, de 23 de maio de 2014 que regulamenta a Lei $\mathrm{n}^{0} 12.101$, de 27 de novembro de 2009, as entidades beneficientes sem fins lucrativos que recebem isenções na contribuição de previdência social deverão oferecer bolsa integral seguindo a observância da proporção de, no mínimo, um aluno cuja renda familiar mensal per capita não exceda o valor de um salário mínimo e meio para cada cinco alunos matriculados (BRASIL, 2014).

Isenções fiscais e previdenciárias injetam indiretamente recursos públicos no ensino privado, sendo assim o financiamento público parceiro para expansão do mercado educacional, configurando, portanto, via de privatização da educação, sobretudo do ensino superior.

A escola Waldorf Guimarães Rosa, que concedeu 41,7\% de bolsas aos alunos participantes do ENEM 2015, tem como pessoa jurídica uma mantenedora gerida por associação civil comunitária composta de pais, amigos e professores, sem fins lucrativos, regida por Estatuto Social. Cabe comentar que o terreno onde se situa esta escola foi doado pelo poder público municipal e o maior percentual de bolsas está também associado a esta doação. Os Colégios Santa Úrsula (32,9\% de alunos bolsistas participantes) e Nossa Senhora Auxiliadora (40,7\% de alunos bolsistas participantes) são colégios confessionais.

São escolas inseridas no bloco 2 as que apresentaram as médias de proficiência mais baixas (em ordem crescente de pontuação), inscritas na Tabela 23:

1. Expedicionários Brasileiros (estadual)

2. Dom Alberto José Gonçalves (estadual)

3. Professor Baptista Spinelli (estadual)

4. Colégio Espaço Cultural (privada) 
5. Miguel Jorge (estadual) e Guimarães Júnior (estadual).

A escola estadual Expedicionários Brasileiros obteve média igual a 475 e apesar de ocupar o espaço de uma quadra inteira do bairro Jardim São José, na edição de 2015 do ENEM contou com apenas 15 participantes. Não há percentual de declarantes que afirmaram que as mães concluíram curso superior e 60\% dos participantes são negros. Não há percentual de declarantes que apontaram renda mensal acima de $\mathrm{R} \$ 7.091,01$ e 6,7\% indicaram renda mensal abaixo de R\$ 1.572,00. 46,7\% dos alunos participantes do ENEM são trabalhadores, o que pode indicar que os estudantes pertencentes às famílias que superam a faixa de renda mensal de R\$ 1.572,00 participam na composição da renda familiar.

Dom Alberto José Gonçalves alcançou proficiência média de 481 pontos e é a escola estadual do bloco 2 que teve maior número de participantes no ENEM 2015 matriculados no terceiro ano do Ensino Médio, com 103 participantes. 43,7\% são negros e 1,9\% informaram que as mães completaram a Educação Superior. Indicaram faixa de renda acima de R\$ 7.091,01 1\% dos participantes e 49,5\% indicaram ser renda mensal familiar abaixo de RS 1.572,00. Declararam serem alunos em exercício de atividade remunerada $31,1 \%$ dos participantes.

A terceira média de desempenho mais baixa é da escola Professor Domingos João Baptista Spinelli, com 484. A escola contou com a participação de 25 estudantes no ENEM. 8\% das mães dos alunos participantes completaram a Educação Superior e 32\% dos participantes são negros. Nenhum aluno assinalou a opção de renda acima de R\$ 7.091,01 e $56 \%$ indicaram como faixa de renda mensal abaixo de RS 1.572,00. Os alunos que trabalham representam $24 \%$ dos participantes do exame.

O quarto pior desempenho na edição de 2015 do ENEM foi da escola particular Espaço Cultural que alcançou proficiência média de 489 pontos com a participação de 7 alunos do terceiro ano. 42,9\% das mães concluíram curso superior, 14,3\% dos alunos participantes são negros. 14,3\% afirmaram que a renda mensal supera R\$ 7.091,01 e não houve percentual de alunos que declarassem renda abaixo de RS 1.572,00. 28,6\% dos participantes exerciam atividade remunerada e ninguém contava com bolsa de estudos.

A escola Espaço Cultural não se insere no desenho socioeconômico dos perfis da escola pública, exceto em relação ao percentual de alunos trabalhadores, assim como a escola Liceu Samuel Pfromm Netto (média 576) que indicou que 33,3\% dos alunos participantes do ENEM 2015 exerciam atividade remunerada.

A segunda menor nota entre as escolas privadas é da escola Castelo com 498 pontos, 9 participantes; 55,6\% de mães com Educação Superior; nenhum aluno declarado negro, 
nenhum aluno trabalhador e 44,4\% com renda acima de $\mathrm{R} \$ 7.092,01$ mensais. Como já mencionado anteriormente, em geral, são escolas com número reduzido de alunos, fundadas há pouco tempo, com mensalidades mais acessíveis e alocadas em prédios inadequados ou imóveis adaptados. Esse modelo de escola representa a "fuga” da classe média do ensino público.

Abaixo, a imagem da fachada da escola privada Castelo.

IMAGEM 4 - ESCOLA CASTELO - FACHADA

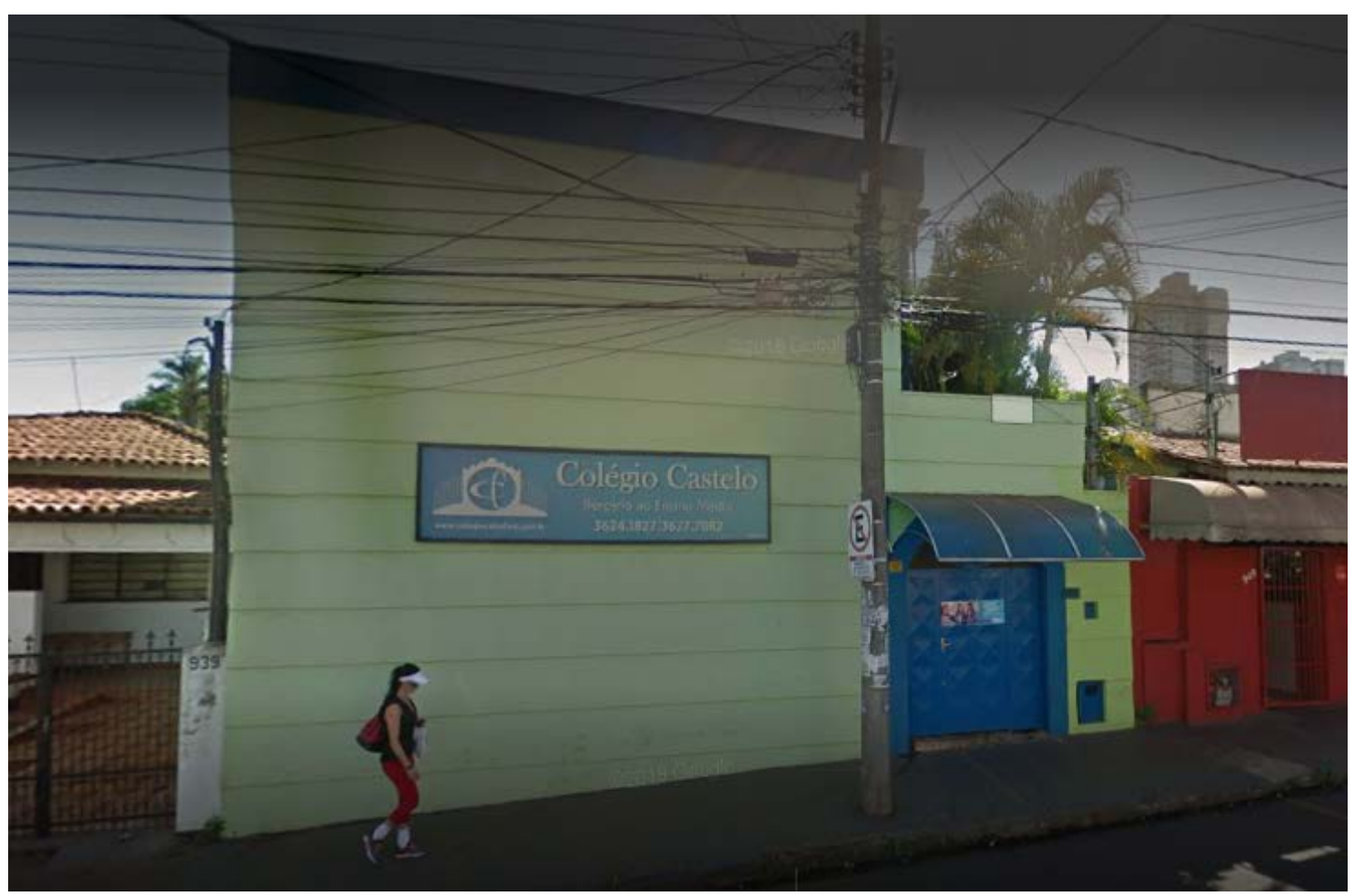

FONTE: GOOGLE MAPS

A quinta média mais baixa é 492 pontos e pertence à escola Miguel Jorge e à escola Guimarães Júnior.

A escola Miguel Jorge contou com 89 participantes dos quais 22,5\% são negros, tratando-se do terceiro menor percentual de negros participantes do ENEM 2015 entre as escolas públicas. 13,5\% das mães terminaram um curso superior; 2,2\% informaram faixa salarial acima de $\mathrm{R} \$ 7.092,01$ e 38,2\%, abaixo de $\mathrm{R} \$ 1.572,00$. 38,2\% dos alunos do terceiro ano que fizeram a prova do ENEM exerciam atividade remunerada.

A tradicional escola estadual Guimarães Júnior (Imagem 5) teve 86 participantes, 47,7\% negros. 4,7\% de mães completaram a Educação Superior, nenhum participante indicou faixa de renda maior que $\mathrm{R} \$ 7.092,01$ e 58,1\% indicaram ganho mensal inferior à $\mathrm{R}$ \$ 
1.572,00, o maior percentual indicado entre as escolas aqui analisadas. Essa escola foi um dos primeiros grupos escolares de Ribeirão Preto, possui um prédio imponente, é praticamente vizinha à Matriz Diocesana da cidade, mas situa-se em uma região onde predomina a atividade comercial e prédios com apartamento de custo elevado frequentado por famílias, em geral mais idosas, da classe média alta. Portanto, seus estudantes não residem nas vizinhanças.

IMAGEM 5 - ESCOLA ESTADUAL GUIMARÃES JÚNIOR

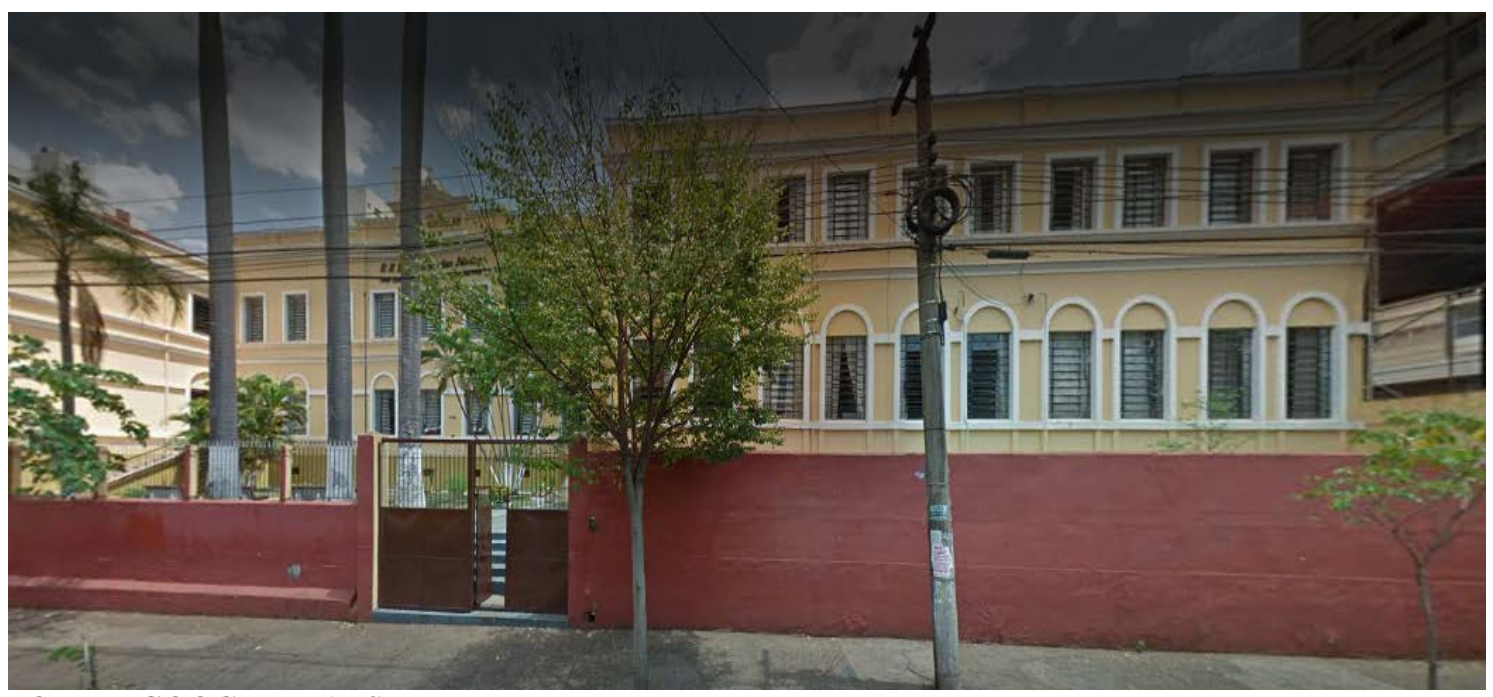

FONTE: GOOGLE MAPS

As escolas Guimarães Júnior e Miguel Jorge sintetizam as características que compõe o perfil das escolas públicas de Ribeirão Preto. Baixa pontuação, elevado número de matrículas, grande percentual de alunos negros, baixa escolaridade das mães, baixa renda e número significativo de alunos que trabalham.

A partir desta realidade, é necessário refletir que as escolas privadas que possuem indicadores socioeconômicos muito favoráveis à produção de resultados de avaliação, reduzido número de alunos por turma que se dedicam exclusivamente aos estudos são condições ausentes nos contextos da trajetória dos alunos da escola pública e não podem em nenhuma hipótese serem tomadas como oferta de qualidade do ensino. Portanto, o ranking brasileiro do Ensino Médio “se baseia no 'valor absoluto’, isto é, no valor expresso pelos resultados dos alunos em teste de proficiência, e não no 'valor adicionado' pelo estabelecimento de ensino” (ANDRADE, 2011 apud NOGUEIRA; LACERDA, 2013, p. 130, 2014).

Para Soares (2008), a lista de divulgação do ENEM era mais um instrumento da imprensa causador de impacto, do que ferramenta de análise sobre a qualidade do Ensino 
Médio público, posição muito contrária à justificativa dada pelo INEP de que os rankings auxiliam estudantes, pais e professores no conhecimento e reflexões sobre necessárias melhorias no Ensino Médio. Na verdade os rankings foram sustentados pelo argumento das políticas de accountability, ou seja, na responsabilização sob o pretexto da transparência.

No plano familiar, a escolha da escola pelas famílias “intelectualizadas” propicia indiretamente uma comparação do perfil social um grupo quanto aos níveis cultural e socioeconômico, a constatar se são próximos ou não de sua realidade (VAN ZANTEN, 2010), a exemplo da Escola Waldorf Guimarães Rosa de Ribeirão Preto algumas escolas privadas que obtêm médias equivalentes às da escola pública, considerada sucateada. Isso se confunde com reconhecimento da qualidade da escola, o que se torna ainda mais evidente no caso dos rankings que permanecem imutáveis ao longo dos anos certificando, assim, a hegemonia de certos grupos empresariais em plena disputa que configura a hierarquia escolar local.

Em suma, por diversos caminhos, sejam eles pela seleção das famílias através do perfil social, midiáticos ou pela via competitiva entre os estabelecimentos, a construção de rankings através avaliações padronizadas como o ENEM não acrescenta apoio à análise da qualidade do ensino, refletindo basicamente o background socioeconômico dos participantes. 


\section{CONSIDERAÇÕES FINAIS}

Os primeiros estudos sobre avaliação da qualidade sustentados pela análise de proficiências ocorreram na segunda metade do século XX e priorizavam essencialmente os determinantes extraescolares socioeconômicos e familiares, não buscando equacionar os fatores socioeconômicos e intraescolares aos resultados dos testes padronizados. Posteriormente, o cunho empresarial imputado à educação na década das reformas (1990) creditava ao ideário de competição um caráter fomentador de qualidade das escolas, e o Estado passa a ter como mandatário o mercado que dita quais os critérios de eficiência e praticamente "neutraliza” a dimensão "contexto”, suprimindo a multiplicidade de fatores que confluem na produção dos desempenhos.

A equidade passou a ser considerada pelo INEP como um dos eixos da qualidade da educação quando o acesso à educação foi considerado um problema menor, pois se estendeu aos grupos mais pobres da população. Assim foi possível considerar que os resultados das avaliações voltadas a este público são claramente hierarquizados pelas suas condições socioeconômicas, como acontece no ENEM, e modelado pelo o teor reformista do campo avaliativo (prevalecente no mercado educacional da rede privada) que se vale estritamente do sucesso individual como diferenciação e seleção social.

Embora o ENEM tenha outras importantes atribuições, como o uso de seus resultados como critério de ingresso na Educação Superior, o ranqueamento do desempenho das escolas é um mero reforçador da seleção social, e este estudo evidenciou, prioritariamente, que escolas das redes privada e pública de Ribeirão Preto participantes do ENEM 2015 foram claramente divididas entre um grupo privilegiado com um nível socioeconômico mais alto e as escolas excluídas do pelotão de elite, que possuem nível socioeconômico mais baixo e, por consequência, um pior desempenho de seus estudantes no exame. 72\% dos participantes alunos de escolas públicas declararam renda mensal familiar de até $\mathrm{R} \$ 2.364,00$ e 32\% dos alunos da rede privada declararam renda acima de $\mathrm{R} \$$ 9.456,00 por mês. Entre os participantes que obtiveram pontuação maior que 750, 53\% indicaram a maior faixa de renda familiar (igual ou superior a $\mathrm{R} \$ 9.456,00$ ), enquanto $78 \%$ dos alunos participantes do exame que alcançaram menos que 450 pontos declararam renda igual ou inferior a $\mathrm{R} \$ 2.364,00$.

O ENEM é um exame de caráter voluntário e, em geral, os alunos se inscrevem por iniciativa própria, exceto aqueles de desempenho destacado que são estimulados através da 
concessão de bolsas de estudos nos colégios particulares e segregados em unidades diferentes, como no caso do SEB COC em Ribeirão Preto, que concede bolsas a 8,7\% de alunos matriculados na unidade líder do ranking e 11,9\% na unidade agregada, a fim de garantir-lhes o topo das posições e ganhar notoriedade no espaço publicitário.

Diante disso, é um erro dizer que o ensino privado é bom somente porque ocupam os primeiros patamares do ranking do ENEM. O exame não pode ser tomado com um descritor da qualidade do ensino, pois não há amostragem confiável de alunos de cada escola que permita concluir análises sobre a qualidade, e que garanta que os alunos de distintos níveis socioeconômicos presentes em cada escola estejam representados na amostra de participantes. O ENEM, portanto, não avalia a qualidade das escolas, mas apenas o desempenho individual de seus participantes, que, como visto nesse trabalho e em todos aqueles que se debruçam sobre o mesmo tema, depende basicamente do capital cultural e econômico das famílias.

A análise dos dados do ENEM 2015 de Ribeirão Preto sobre os motivos que levaram à participação no exame, fez possível observar que os alunos da rede privada almejam primeiramente as vagas em universidade públicas. Avaliando que suas chances de ingresso nas universidades públicas são menores, $77 \%$ dos alunos da rede pública apontaram em máxima escala como motivo de realizar o ENEM a tentativa de conseguir bolsa de estudo, vendo assim alternativa para o ingresso nas instituições privadas, o que salienta sua expectativa mais factível de prosseguir na educação superior.

Ademais, de algum modo, o ENEM como acesso à educação superior pública via SISU contribui com a "insatisfação" do setor privado de ensino ao romper, em parte, com a impermeabilidade do Ensino Superior para as classes populares, já que a mobilidade social “atenua” a luta de classes e o capital vê seus ganhos ameaçados.

Entretanto, o caráter seletivo do ENEM interage com a dualidade do Ensino Médio, que há tempos é uma etapa bastante comprometida da Educação Básica em virtude do esvaziamento de matrículas, pela falta de identidade e pelos recentes retrocessos decorrentes das reformas autoritárias empreendidas em 2017. A Lei $n^{\circ}$ 13.415/2017 que estabelece a reforma do Ensino Médio vai contra esforços de décadas no combate da dualidade histórica do Ensino Médio sob a justificativa da modernização e investimento em capital humano (ou seria mão de obra barata?) para alavancar a competitividade do país no cenário econômico internacional. Flexibilização do currículo, medidas de austeridade seguidas de cortes de recursos da educação não significam propriamente investir no capital humano e na melhoria da qualificação de jovens trabalhadores, mas vai de encontro com a intenção da OCDE de articular educação, crescimento econômico e desenvolvimento social. 
Não obstante, a crise no MEC em 2019 se acentua dia após dia e as políticas educacionais estão à deriva. O ENEM que demanda uma operação logística bem articulada não tem hoje um responsável dentro do $\mathrm{INEP}^{39}$, o que coloca em risco o ingresso dos estudantes ao Ensino Superior.

Para além do caráter seletivo e eventual via de ingresso de estudantes da rede pública de educação básica na universidade, o ENEM é um espelho do nível socioeconômico dos alunos, portanto o seu conceito estatístico não favorece a equidade nem tampouco dá apoio às políticas de qualidade para o Ensino Médio, pois mais oculta que esclarece as causas dos diferentes desempenhos.

A verticalização da avaliação da qualidade do Ensino Médio leva a sociedade a um juízo equivocado sobre a qualidade, que acredita que médias mais altas equivalem à qualidade mais alta, e também acorrenta o processo educativo a conteúdos pétreos que preparam o jovem aluno para o exame, mas não para a vida, distante de uma educação omnilateral e de perspectiva democrática.

\footnotetext{
${ }^{39}$ https://www.cartacapital.com.br/educacao/sem-grafica-e-sem-coordenador-enem-de-2019-estaameacado/?utm campaign=newsletter $r d$ - 03042019\&utm medium=email\&utm source=RD+Station
} 


\section{REFERÊNCIAS}

AFONSO, A. J. Políticas educativas e avaliação educacional: para uma análise sociológica da reforma educativa em Portugal (1985-1995). Minho: Centro de Estudos em Educação e Psicologia, Universidade do Minho, 1998.

ALBERNAZ, Â.; FERREIRA, F. H. G.; FRANCO, C. Qualidade e equidade na educação fundamental brasileira. Pesquisa e Planejamento Econômico, v. 32, n. 3, dez, 2002.

ALVES, M. T. G.; SOARES, J. F. Contexto escolar e indicadores educacionais: condições desiguais para a efetivação de uma política de avaliação educacional. Educação e Pesquisa, São Paulo, v. 39, n. 1, p. 177-194, jan./mar. 2013.

ALVES, M. T. G.; SOARES, J. F.; XAVIER, F. P Índice Socioeconômico das Escolas de Educação Básica Brasileiras. Ensaio: Aval. Pol. Públ. Educ. Rio de Janeiro, v.22, n. 84, p. 671-704, jul./set. 2014.

ALVES, P. A. ENEM como política pública de avaliação. Dissertação de Mestrado em Políticas Públicas e Formação Humana. Universidade do Estado do Rio de Janeiro. Rio de Janeiro: Faculdade de Educação, 2009.

ANDRADE, E. Rankings em educação: tipos, problemas, informações e mudanças: análise dos principais rankings oficiais brasileiros. Estudos Econômicos, São Paulo, v. 41, p. 379406, set./dez. 2011.

ANDRADE, J. M.; LAROS, J. A. Fatores associados ao desempenho escolar: estudo multinível com dados do Saeb/2001. Psicologia: Teoria e Pesquisa, v. 23, n. 1, p. 33-41, jan./mar. 2007.

ARAÚJO, M. L. H. S. Avaliação Internacional: Concepções Concernentes ao PISA e seus resultados no Brasil. In: ANPAE - XXVI Simpósio Brasileiro de Política e Administração da Educação, 2013. Disponível em:

www.anpae.org.br/simposio26/1comunicacoes/MaLourdesAraujo-ComunicacaoOral-int.pdf. Acesso em: 25/08/2017.

BALL, S. Reformar escolas/reformar professores e os terrores da performatividade. Revista Portuguesa de Educação, Portugal, vol. 15, n. 2, 2002. Disponível em: http://josenorberto.com.br/BALL.\%2037415201.pdf. Acesso em: 15/03/2018.

BESSA, J. T. S. A importância do ranking do ENEM para a sociedade e as diferenças entre as redes de ensino. 74f. Dissertação - Programa de Pós-graduação em Matemática, Universidade Federal Rural do Semiárido, Mossoró, 2016.

BONAMINO, A.; CAZELLI, S.; ALVES F.; FRANCO, C. Os efeitos das diferentes formas de capital no desempenho escolar: um estudo à luz de Bourdieu e de Coleman. Revista Brasileira de Educação, v. 15 n. 45 set./dez. 2010. Disponível em: www.scielo.br/pdf/rbedu/v15n45/07.pdf. Acesso em 10/04/2019. 
BONAMINO, A.; FRANCO, C. Avaliação e política educacional: o processo de institucionalização do SAEB. Cadernos de Pesquisa, nº ${ }^{108}$, nov.1999.

BOURDIEU, P. Capital simbólico e classes sociais. Tradução de: Fernando Pinheiro, Introdução e notas de: Loïc Wacquant. Novos estud. - CEBRAP, São Paulo, n. 96, p. 105115, jul. 2013. Disponível em:

www.scielo.br/scielo.php?script=sci_arttext\&pid=S010133002013000200008. Acesso em: 02/02/2019.

BRASIL. Constituição Federal. Constituição da República Federativa do Brasil. Brasília, DF: Senado, 1988.

BRASIL. Decreto de Lei $N^{\circ}$ 8.242, de 23 de maio de 2014. Diário Oficial da União, Brasília-DF, 2014. Disponível em:

www.in.gov.br/materia//asset_publisher/Kujrw0TZC2Mb/content/id/30055786/do1-2014-0526-decreto-no-8-242-de-23-de-maio-de-2014-30055782. Acesso em: 22/04/2019.

BRASIL. Emenda Constitucional $n^{0}$ 59, de 11 de novembro de 2009. Brasília: Presidência da República, Casa Civil, Subchefia para Assuntos Jurídicos. Disponível em: www.planalto.gov.br/ccivil_03/Constituicao/Emendas/Emc/emc59.htm. Acesso em: 13/06/2018.

BRASIL. Lei no 5692, de 11 de agosto de 1971.

BRASIL. Lei n ${ }^{\circ}$ 7044, de 18 de outubro de 1982.

BRASIL. LDB n ${ }^{0}$ 9.394, de 20 de dezembro de 1996.

BRASIL. Lei $\mathbf{n}^{0}$ 10.260, de 12 de Julho de 2001. Disponível em: www.planalto.gov.br/ccivil_03/leis/leis_2001/110260.htm. Acesso em: 19/11/2017.

BRASIL. Lei $\mathbf{n}^{0}$ 12.101, de 27 de novembro de 2009. Disponível em: www.planalto.gov.br/ccivil_03/_Ato2007-2010/2009/Lei/L12101.htm. Acesso em: 23/02/2019.

BRASIL. Lei ${ }^{\circ}$ 13.005, de 25 de junho de 2014. Disponível em: www.planalto.gov.br/ccivil_03/_Ato2011-2014/2014/Lei/L13005.htm. Acesso em: 27/05/2018.

BRASIL. Instituto Nacional de Estudos e Pesquisas Educacionais Anísio Teixeira. Exame Nacional do Ensino Médio. Documento básico. Brasília, DF, 1999.

BRASIL. Instituto Nacional de Estudos e Pesquisas Educacionais Anísio Teixeira. Exame Nacional do Ensino Médio. Documento básico. Brasília, DF, 2002.

BRASIL. Instituto Nacional de Estudos e Pesquisas Educacionais Anísio Teixeira. Exame Nacional do Ensino Médio (Enem): fundamentação teórico-metodológica. Brasília, 2005.

BRASIL. Instituto Nacional de Estudos e Pesquisas Educacionais Anísio Teixeira. Plano Nacional de Educação PNE 2014-2024: Linha de Base. - Brasília-DF, 404 p., 2015. 
BRASIL. Instituto Nacional de Estudos e Pesquisas Educacionais Anísio Teixeira. Relatório pedagógico: Enem 2011-2012. - Brasília, DF, 236 p.: Inep, 2015. PDF.

BRASIL. Instituto Nacional de Estudos e Pesquisas Educacionais Anísio Teixeira. Brasil no PISA 2015: Análises e reflexões sobre o desempenho dos estudantes brasileiros, Fundação Santillana. Brasília-DF: Inep, 2016. 274 p.

BRASIL. Instituto Nacional de Estudos e Pesquisas Educacionais Anísio Teixeira. Sistema de Avaliação da Educação Básica - Projeto Básico - v.6, Brasília-DF, 2017.

BRASIL. Instituto Nacional de Estudos e Pesquisas Educacionais Anísio Teixeira. DAEB. Sistema de Avaliação da Educação Básica - Documentos de Referência - Versão 1.0. Brasília-DF, 2018.

BRASIL. Instituto Nacional de Estudos e Pesquisas Educacionais Anísio Teixeira Relatório Saeb (Aneb e Anresc) 2005-2015: panorama da década. Brasília, 2018.

BRASIL. Portaria no 438, de 28 de maio de 1998. Disponível em: http://download.inep.gov.br/educacao_basica/enem/legislacao/2010/portaria4_enem_certifica cao_ensino_medio.pdf. Acesso em: 04/04/2019.

BRASIL. Portaria n 931, de Março de 2005. Disponível em: www.inep.gov.br/download/saeb/2005/portarias/Portaria931_NovoSaeb.pdf. Acesso em: 12/10/2017.

BRASIL. Portaria no 109, de 27 de maio de 2009. Brasília, 2009. Disponível em: www.in.gov.br/materia/asset_publisher/Kujrw0TZC2Mb/content/id/20209746. Acesso em: 04/04/2019.

BRASIL. Portaria $\mathbf{n}^{\mathbf{0}}$ 807, de 18 de Junho de 2010. Disponível em: http://download.inep.gov.br/educacao_basica/enem/legislacao/2010/portaria807_180610.pdf. Acesso em: 25/11/2017.

BRASIL. Portaria no 342, de 28 de Setembro de 2012. Disponível em: http://download.inep.gov.br/educacao_basica/enem/legislacao/2012/portaria_enem_por_escol as_2012.pdf. Acesso em: 25/11/2017.

BRASIL. Portaria $\mathbf{n}^{0}$ 501, de 27 de setembro de 2016. Disponível em: www.in.gov.br/materia//asset_publisher/Kujrw0TZC2Mb/content/id/21919557/do1-2016-0919-portaria-n-501-de-16-de-setembro-de-2016-21919381. Acesso em: 17/01/2019.

BRASIL. Portaria $n^{\mathbf{0}}$ Portaria $\mathbf{n}^{\mathbf{0}} 468$ de 03 de Abril de 2017. Disponível em: http://download.inep.gov.br/educacao_basica/enem/legislacao/2017/Portaria_mec_gm_n468 de_03042017_dispoe_sobre_a_realizacao_do_enem.pdf. Acesso em: 25/11/2017.

BROOKE, N. SOARES, J. F. (org). Pesquisa em eficácia escolar: origens e trajetórias. Belo Horizonte: Editora da UFMG, 2008. 
BUCHMANN, C.; HANNUM, E. Education and stratification in developing countries: a review of theories and research. Annu. Rev. Sociol, v. 27, p. 77-102, 2001. Disponível em: www.annualreviews.org/doi/pdf/10.1146. Acesso em 22/06/2017.

CASASSUS, Juan. A escola e a desigualdade. Tradução Lia Zatz. 2. ed. Brasília: Líber Livro Editora, Unesco, 2007, 204 p.

CASASSUS, Juan. Uma nota crítica sobre a avaliação estandardizada: a perda da qualidade e a segmentação social. Sísifo: Revista de Ciências da Educação, p. 71-79, 2009. Disponível em: www.sisifo.fpce.ul.pt. Acesso em: 30/11/2017.

CAZELLI , S. Ciência, cultura, museus, jovens e escolas: quais as relações? 260f. Tese Programa de Pós-Graduação em Educação do Departamento de Educação do Centro de Teologia e Ciências Humanas, PUC-Rio, Rio de Janeiro, 2005.

CLEMENTE, C. M.; SOUZA, D. S. O ENEM como parte da reforma educacional brasileira e como política pública de avaliação. In: $8^{\circ}$ Encontro Internacional de Formação de Professores, Brasil, Sergipe. Anais. $10^{\circ}$ Fórum Permanente de Inovação Educacional. Ciência, Trabalho, Educação e Interculturalidade,v. 9, n.1, Aracaju, 2016.

COELHO, M. I. M. Vinte anos de avaliação na educação básica do Brasil: aprendizagens e desafios. Ensaio: Avaliação das Políticas Públicas em Educação, Rio de Janeiro, v. 16, n. 59, p. 229-258, abril/ junho, 2008.

COLEMAN, J. Equality of Educational Opportunity. Washington: National Center for Educational Statistics, 737 p., 1966.

DIAS SOBRINHO, J. Avaliação da educação superior. Petrópolis: Vozes, 2000.

DIAS SOBRINHO, José. Avaliação: políticas educacionais e avaliação da educação superior. São Paulo: Cortez, 2003.

FERNANDES, Reynaldo. Índice de desenvolvimento da educação básica (IDEB): metas intermediárias para a sua trajetória no Brasil, estados, municípios e escolas, 2007. Disponível em: http://download.inep.gov.br/educacao_basica/portal _IDEB/metodologias/Artigo_projecoes.pdf. Acesso em: 07/07/2017.

FERRARO, A. R. Escolarização no Brasil: articulando as perspectivas de gênero, raça e classe social. Educação e Pesquisa, São Paulo, v. 36, n.2, p. 505-526, maio/ago. 2010. Disponível em: www.scielo.br/pdf/ep/v36n2/a06v36n2.pdf. Acesso em: 15/02/2019.

FERREIRA, F.H.G.; PAES DE BARROS, R. Education and income distribution in urban Brazil, 1976-1996. Cepal Review (0)71, p.41-61, ago. 2000. Disponível em: http://archivo.cepal.org/pdfs/revistaCepal/En/71041061I.pdf. Acesso em 22/04/2019.

FIGUEIREDO, D.; CARMO, E.; MAIA, R.; SILVA, L.. Ensaio Os cavalos também caem: Tratado das inconsistências do IDEB: Aval. Pol. Públ. Educ., Rio de Janeiro, v.26, n.100, p. 552-572, jul./set. 2018. 
FRANCO, Creso. O SAEB Sistema de Avaliação da Educação Básica: potencialidades, problemas e desafios. Rev. Bras. Educ., n.17, pp.127-133, 2001. Disponível em: www.scielo.br/scielo.php?pid=S141324782001000200010\&script=sci_abstract\&tlng=pt. Acesso em: 22/06/2017.

FRANCO, Creso. et al. Qualidade e equidade em educação: reconsiderando o significado de "fatores intra-escolares". Ensaio: aval. pol. públ. Educ., vol.15, n.55, p. 277-298, 2007. Disponível em: www.scielo.br/pdf/ensaio/v15n55/a07v1555.pdf. Acesso em: 29/08/2017.

FRANCO, Creso; BONAMINO, Alícia. O Contexto das Políticas para o Ensino Médio. Química nova na escola: O Enem e o Ensino Médio. Rio de Janeiro, n 10, p. 26-30, nov. 1999.

FRANCO, Creso; BROOKE Nigel; ALVES, Fátima. Estudo longitudinal sobre qualidade e equidade no ensino fundamental brasileiro: GERES 2005. Ensaio: aval. pol. públ. Educ., Rio de Janeiro, v. 16, n. 61, p. 625-638, out./dez. 2008.

FREITAS, Luis Carlos de. Qualidade negociada: avaliação e contra-regulação na escola pública. Educação e Sociedade, Campinas, vol. 26, n. 92, Especial, p. 911-933 out. 2005.

FREITAS, Luis Carlos de. Eliminação Adiada: o caso das Classes Populares no interior da Escola e a ocultação da (Má) Qualidade do Ensino. Educação e Sociedade. Campinas/SP, vol. 28, n. 100 - Especial, p. 965-987, out. 2007.

FREITAS, Luis Carlos de. Responsabilização, meritocracia e privatização: conseguiremos escapar ao neotecnicismo? In: III Seminário de Educação Brasileira e Simpósio PNE:

Diretrizes para Avaliação e Regulação da Educação Nacional. CEDES, São Paulo, fev. 2011.

FRIGOTTO, Gaudêncio. A produtividade da escola improdutiva. Um (re) exame das relações entre educação e estrutura econômico-social capitalista. $4^{\mathrm{a}}$ ed. São Paulo: Cortez, 1993.

FRIGOTTO, Gaudêncio. A educação e formação técnico-profissional frente à globalização excludente e o desemprego estrutural, in: SILVA, Luiz Heron (org) A escola cidadã no contexto da globalização. Petrópolis: Vozes, 1999.

GENTILI, Pablo. O discurso da "qualidade" como nova retórica conservadora no campo educacional. In: GENTILI, Pablo e SILVA, Tomaz Tadeu (org). Neoliberalismo, qualidade total e educação. 9 ed. Petrópolis: Editora Vozes, 2001.

KUENZER, Acácia. O Trabalho como princípio educativo. 3. ed. São Paulo: Cortez, 1997.

KUENZER, Acacia. Ensino Médio: construindo uma proposta para os que vivem do trabalho. 6. ed. São Paulo: Cortez, 2009

KUENZER, A. Z. O ensino médio no Plano Nacional de Educação 2011-2020: superando a década perdida? Educação e Sociedade, Campinas, v. 31, n. 112, set. 2010.

KUENZER, Acacia. EM e EP na produção flexível A dualidade invertida. Revista Retratos da Escola, Brasília, v. 5, n. 8, p. 43-55, jan./jun., 2011. 
LIMA, Elizeth Gonzaga dos Santos. Avaliação Institucional: o uso dos resultados como estratégia de (re)organização dos espaços de discussão na universidade. 260 f. Tese (Doutorado em Educação) - Universidade Estadual de Campinas, Campinas, SP, 2008.

MACEDO, J. D. F.; MEDEIROS, R. M. Formações ideológicas materializadas nas condições de produção do novo ENEM. In: Simpósio Brasileiro de Política e Administração da Educação, 25, São Paulo. Anais. São Paulo, p. 1-10, Pontifícia Universidade Católica de São Paulo, 2011.

MENDES G.; CARAMELO J.; ARELARO L.; TERRASÊCA M.; SORDI M.; KRUPPA S. Educ. Pesqui., São Paulo, v. 41, n. especial, p. 1283-1298, dez., 2015.

MESQUITA, S. S. A.; LELIS, I. A. O. M. Cenários do Ensino Médio no Brasil. Ensaio: Aval. Pol. Públ. Educ., Rio de Janeiro, v.23, n. 89, p. 821-842, out./dez. 2015.

NOGUEIRA, Maria Alice. A relação família-escola na contemporaneidade: fenômeno social/interrogações sociológicas. Análise Social, Lisboa, vol. XL (176), p. 563-578, 2005.

NOGUEIRA, M. A.; LACERDA, W. G. Os rankings de estabelecimentos de ensino médio e as lógicas de ação das escolas. In: NORA KRAWCZYK. (org.). Sociologia do ensino médio: crítica ao economicismo na política educacional. São Paulo: Cortez, 2014. p. 127-161.

OECD. PISA 2012 Technical Report, 2014. Disponível em:

www.oecd.org/pisa/pisaproducts/PISA-2012-technical-report-final.pdf. Acesso em:

25/10/2017.

PEREIRA, F. M. Entre o mérito e as circunstâncias: uma análise dos perfis dos inscritos no ENEM 2013. 73 p. Trabalho de Conclusão de Curso. Setor de Educação, Universidade Federal do Paraná, Curitiba, 2015.

PERRENOUD, P. Avaliação: da excelência à regulação das aprendizagens - entre duas lógicas. Artimed. Porto Alegre, 1999.

PINTO, J. M. O ensino médio. In: OLIVEIRA, R. P.; ADRIÃO, T. (orgs). Romulado Portella e Thereza Adrião (orgs). Organização do ensino no Brasil: níveis e modalidades na Constituição Federal e na LDB. São Paulo: Xamã, p. 51-76, 2002.

QUEIROZ, C. A. P.; MOITA, F. M. G. S. C. Fundamentos sócio-filosóficos da educação. Campina Grande; Natal: UEPB/UFRN, 2007. Anais I SENEPT, CEFET-MG, 2008.

RAVITCH, D. Vida e morte do grande sistema escolar americano: como os testes padronizados e o modelo de mercado ameaçam a educação. Trad. de Marcelo Duarte. Porto Alegre: Sulina, 2011.

REIS, M. C.; RAMOS, L. Escolaridade dos Pais, Desempenho no Mercado de Trabalho e Desigualdade de Rendimentos. RBE, Rio de Janeiro, v. 65 n. p. 177-205, 2, abr./jun. 2011. 
RISCAL, José Reinaldo; LUIZ, Maria Cecília. Gestão democrática e a análise de avaliações em larga escala: o desempenho de escolas públicas no Brasil. São Carlos: Pixel, Coleção Especialização, 159 p. 2016.

ROMANELLI, R. A. A cosmovisão antroposófica: educação e individualismo ético Educar em Revista, n. 56, p. 49-66, Curitiba, abr./jun. 2015. Disponível em: www.scielo.br/pdf/er/n56/0101-4358-er-56-00049.pdf. Acesso em 22/04/2019.

SALEJ, S. Quarenta anos do Relatório Coleman: capital social e educação. Educação Unisinos, n. 2, vol. 9, mai/ago. 2005.

SALEJ, S Os Fundamentos Teóricos do Capital Social Chapecó, Argos Ed. Universitária, 263 p., 2005.

SAMPAIO, M. M. F.; MARIN, A. J. Precarização do Trabalho Docente e seus Efeitos Sobre as Práticas Curriculares. Educ. Soc., Campinas, vol. 25, n. 89, p. 1203-1225, Set./Dez., 2004.

SILVA, Isabelle Fiorelli. O sistema nacional de avaliação: características, dispositivos legais e resultados. Est. Aval. Educ., São Paulo, v. 21, n. 47, p. 427- 448, set./dez. 2010.

SILVA, M. R.. Sociologia do Ensino Médio: crítica ao economicismo na política educacional. Educ. Soc., Campinas, v. 36, nº. 130, p. 249-252, jan./mar. 2015.

SILVEIRA, F. L.; BARBOSA, M. C. B.; SILVA, R. Exame Nacional do Ensino Médio (ENEM): Uma análise crítica Rev. Bras. Ensino Fís., São Paulo, vol.37, no.1, p. 1101-21001-5. mar. 2015

SOUSA, Sandra Zákia. Ensino Médio: Perspectivas de Avaliação. Revista Retratos da Escola, Brasília, DF, v. 5, n. 8, p. 99-110, jan./jun. 2011.

SOUSA, Sandra Zákia. Concepções de qualidade da educação básica forjadas por meio de avaliações em larga escala. Avaliação, Campinas; Sorocaba, SP, v. 19, n. 2, p. 407-420, jul. 2014.

SOUSA, S. Z.; OLIVEIRA, R. P. Sistemas estaduais de avaliação: uso dos resultados, implicações e tendências. Cadernos de Pesquisa, v.40, n.141, p.793-822, set./dez. 2010.

SOARES, J. F.; ALVES, M. T. Contextualização dos resultados das escolas de ensino fundamental. Retratos da Escola, v. 7, p. 145-158, 2013.

SOARES, J. F.; XAVIER, F. P. Pressupostos educacionais e estatísticos do IDEB. Educ. Soc., Campinas, v. 34, n. 124, p. 903-923, jul./set. 2013. Disponível em www.scielo.br/pdf/es/v34n124/13.pdf. Acesso em 04/04/2019.

TERRASÊCA, M. Autoavaliação, avaliação externa... afinal para que serve a avaliação das escolas? Cad. Cedes, Campinas, v. 36, n. 99, p. 155-174, maio-ago. 2016. Disponível em: www.scielo.br/pdf/ccedes/v36n99/1678-7110-ccedes-36-99-00155.pdf. Acesso em: 01/04/1019. 
TRAVITZKI, Rodrigo. ENEM: Limites e Possibilidades do exame Nacional do ensino Médio enquanto indicador de qualidade 322 p. Tese. (Doutorado em Filosofia e Educação). Universidade de São Paulo, São Paulo, 2013.

UNESCO. Educational Achievements of Thirteen Year Olds in Twelve Countries: Results of an international Research project, 1959-61. Hamburgo: Unesco Institute for Education, 68 p. 1962.

VAN ZANTEN, A. A escolha dos outros: julgamentos, estratégias e segregações escolares. Educação em Revista. Belo Horizonte, v.26, n. 3, p. 409-34, dez. 2010.

ZANCHET. B. M. O Exame Nacional do Ensino Médio: Uma auto avaliação para quem? Avaliação- Revista da Rede de Avaliação Institucional da Educação Superior, v. 8, n.1, p. 247-268, mar. 2003. 


\section{ANEXOS}

\section{ANEXO 1 - DESTAQUES NORMATIVOS E MARCOS REFERENCIAIS DA HISTÓRIA DO ENEM (2009 A 2017)}

\begin{tabular}{|c|c|c|c|}
\hline $\begin{array}{l}\text { PORTARIA } \\
\text { MEC/INEP }\end{array}$ & $\mathbf{N}^{\circ}$ - DATA & $\begin{array}{c}\text { DISPOSIÇÕES } \\
\text { LEGAIS }\end{array}$ & CONTEÚDO/INOVAÇÕES \\
\hline MEC & $\begin{array}{c}\text { No }^{\circ} 468 \text { de } 03 \\
\text { de Abril de } \\
2017\end{array}$ & $\begin{array}{l}\text { Sobre a realização } \\
\text { de ENEM e dá } \\
\text { outras providências. } \\
\text { Revoga Portaria } N^{\circ} \\
807 \text { de } 18 \text { de Junho } \\
\text { de } 2010 .\end{array}$ & $\begin{array}{l}\text { - Constitui objetivo primordial do exame: aferir domínios de } \\
\text { princípios científicos, tecnológicos e linguagem contemporânea; } \\
\text { discorre sobre as responsabilidades do INEP; discorre sobre os } \\
\text { resultados do ENEM que deverão possibilitar: a constituição de } \\
\text { parâmetros para a autoavaliação do participante, com vistas à } \\
\text { continuidade de sua formação e a sua inserção no mercado de } \\
\text { trabalho; aperfeiçoamento dos currículos do ensino médio; acesso } \\
\text { à educação superior; a sua utilização como instrumento de seleção } \\
\text { para ingresso nos diferentes setores do mundo do trabalho; e o } \\
\text { desenvolvimento de estudos e indicadores sobre a educação } \\
\text { brasileira. } \\
\text { - Isenção de taxa de inscrição destinada ao custeio dos serviços de } \\
\text { elaboração, aplicação e processamento dos resultados não será } \\
\text { cobrada aos concluintes do ensino médio, em qualquer } \\
\text { modalidade de ensino, matriculados em instituições públicas de } \\
\text { ensino. } \\
\text { - Fica suspenso o caráter certificador do exame. } \\
\text { - O INEP disponibilizará um boletim individual ao participante do } \\
\text { ENEM, contendo informações referentes aos seus resultados. } \\
\text { As informações pessoais, educacionais, socioeconômicas e os } \\
\text { resultados individuais do ENEM somente poderão ser divulgados } \\
\text { mediante a autorização expressa do participante. }\end{array}$ \\
\hline INEP & $\begin{array}{c}N^{\circ} 267 \text { de } 19 \\
\text { de Junho de } \\
2015\end{array}$ & $\begin{array}{l}\text { Estabelece os } \\
\text { procedimentos e } \\
\text { critérios para a } \\
\text { divulgação dos } \\
\text { resultados do } \\
\text { ENEM } 2014 \text { por } \\
\text { Escola }\end{array}$ & $\begin{array}{l}\text { Considera-se participante do exame alunos que realizaram as } \\
\text { quatro provas objetivas (com nota maior que zero) e redação. } \\
\text { Serão divulgados os resultados apenas das escolas que tiverem } \\
\text { pelo menos } 10 \text { alunos participantes. Os resultados do Enem por } \\
\text { Escola serão formados pelas médias das proficiências dos alunos } \\
\text { participantes, por área do conhecimento e redação, e pela } \\
\text { distribuição percentual dos alunos em faixas de proficiência, para } \\
\text { cada área e para a redação. }\end{array}$ \\
\hline INEP & $\begin{array}{c}\mathrm{N}^{\circ} 533, \text { DE } 30 \\
\text { DE } \\
\text { OUTUBRO } \\
\text { DE } 2014\end{array}$ & $\begin{array}{l}\text { Estabelece os } \\
\text { procedimentos e } \\
\text { critérios para a } \\
\text { divulgação dos } \\
\text { resultados do } \\
\text { Exame } \\
\text { Nacional do Ensino } \\
\text { Médio (Enem) } 2013 \\
\text { por Escola } \\
\end{array}$ & $\begin{array}{l}\text { São concluintes do ensino médio os alunos matriculados na } 3^{a} \\
\text { série do ensino médio regular, excluídos os do ensino médio não } \\
\text { seriado, constantes no Censo Escolar 2013; consideram-se } \\
\text { participantes do Enem } 2013 \text { os alunos que realizaram as quatro } \\
\text { provas objetivas e a prova de redação, obtendo proficiências } \\
\text { superiores a zero em todas as provas objetivas. Dispõe sobre a } \\
\text { divulgação dos resultados, formulários de recursos utilizados } \\
\text { pelas escolas a fim de validar a certificação }\end{array}$ \\
\hline INEP & $\begin{array}{c}\mathrm{N}^{\circ} 436 \text {, de } 5 \text { de } \\
\text { Setembro de } \\
2014\end{array}$ & $\begin{array}{c}\text { Estabelece } \\
\text { procedimentos e } \\
\text { prazos para a } \\
\text { utilização dos } \\
\text { resultados no } \\
\text { ENEM em } \\
\text { processos seletivos } \\
\text { de acesso a vagas } \\
\text { em Instituições de } \\
\text { Ensino Superior } \\
\text { (IES) } \\
\end{array}$ & $\begin{array}{l}\text { Discorre sobre as possibilidades de utilização dos resultados do } \\
\text { ENEM pelas IES: } \\
\text { a) Mecanismo Único: neste caso, o ENEM constitui-se como } \\
\text { forma exclusiva de seleção adotada pela IES. } \\
\text { b) Mecanismo Alternativo: neste caso, o ENEM coexiste com } \\
\text { outro processo seletivo utilizado pela IES. } \\
\text { c) Mecanismo Complementar: neste caso, o ENEM é admitido } \\
\text { como uma das fases ou um dos componentes do processo seletivo } \\
\text { utilizado pela IES. }\end{array}$ \\
\hline INEP & $\begin{array}{c}\mathrm{N}^{\mathrm{o}} 179 \text {, de } 28 \\
\text { de Abril de } \\
2014\end{array}$ & $\begin{array}{l}\text { Dispõe sobre o } \\
\text { processo de } \\
\text { certificação, as } \\
\text { competências das } \\
\text { Instituições } \\
\end{array}$ & $\begin{array}{l}\text { Dispõe sobre critérios para certificação: } \\
\text { - indicar a pretensão de utilizar os resultados de para fins de } \\
\text { certificação de conclusão do Ensino Médio, no ato da inscrição, } \\
\text { bem como a Instituição Certificadora; } \\
\text { - possuir no mínimo } 18 \text { anos completos na data da primeira prova }\end{array}$ \\
\hline
\end{tabular}




\begin{tabular}{|c|c|c|c|}
\hline & & $\begin{array}{c}\text { Certificadoras e do } \\
\text { INEP e os requisitos } \\
\text { necessários à } \\
\text { obtenção de } \\
\text { certificado de } \\
\text { conclusão do } \\
\text { Ensino Médio e } \\
\text { declaração parcial } \\
\text { de proficiência com } \\
\text { a utilização dos } \\
\text { resultados de } \\
\text { desempenho obtidos } \\
\text { no ENEM. }\end{array}$ & $\begin{array}{l}\text { de cada edição do exame; } \\
\text { - atingir o mínimo de } 450 \text { pontos em cada uma das áreas de } \\
\text { conhecimento do exame e no mínimo de } 500 \text { pontos na redação. }\end{array}$ \\
\hline INEP & $\begin{array}{l}\mathrm{N}^{\circ} \text { 342, DE } 28 \\
\text { DE } \\
\text { SETEMBRO } \\
\text { DE } 2012\end{array}$ & $\begin{array}{c}\text { Estabelece } \\
\text { sistemática para } \\
\text { cálculo e divulgação } \\
\text { da proficiência } \\
\text { média dos } \\
\text { participantes do } \\
\text { ENEM. }\end{array}$ & $\begin{array}{l}\text { Serão calculadas proficiências médias dos estudantes que } \\
\text { realizaram o ENEM em 2011, por unidade escolar, em cada uma } \\
\text { das quatro Provas Objetivas e da Redação. } \\
\text { Os participantes do ENEM } 2011 \text { a serem considerados para o } \\
\text { cálculo das proficiências médias deverão atender } \\
\text { concomitantemente aos seguintes requisitos: } \\
\text { - terem sido declarados por suas escolas ao Censo Escolar } 2011 \text { e } \\
\text { matriculados nos anos finais do Ensino Médio; } \\
\text { - tenham realizado as quatro provas objetivas e a prova de } \\
\text { redação. } \\
\text { A taxa de participação no ENEM } 2011 \text { corresponde à razão entre } \\
\text { o número total de estudantes da escola declarados ao } \\
\text { Censo Escolar 2011, que tenham realizado o ENEM 2011, e o } \\
\text { número total de matrículas nos anos finais do Ensino Médio } \\
\text { Regular declarado, pela unidade escolar, ao Censo Escolar 2011. }\end{array}$ \\
\hline INEP & $\begin{array}{l}\mathrm{N}^{\mathrm{o}} 144 \text {, de } 24 \\
\text { de Maio de } \\
2012\end{array}$ & $\begin{array}{l}\text { Dispõe sobre os } \\
\text { critérios de } \\
\text { certificação de } \\
\text { conclusão do ensino } \\
\text { médio ou } \\
\text { declaração parcial } \\
\text { de proficiência com } \\
\text { base no ENEM. }\end{array}$ & $\begin{array}{l}\text { Destinam-se aos maiores de } 18 \text { anos que não concluíram o ensino } \\
\text { médio em idade apropriada, inclusive às pessoas privadas de } \\
\text { liberdade requisitos: } \\
\text { - atingir o mínimo de } 450 \text { pontos em cada uma das áreas de } \\
\text { conhecimento do exame e no mínimo de } 500 \text { pontos na redação. } \\
\text { O INEP disponibilizará as notas e os dados cadastrais dos } \\
\text { participantes interessados, às Secretarias de Educação dos Estados } \\
\text { e do Distrito Federal e aos Institutos Federais de Educação, } \\
\text { Ciência e Tecnologia que aderirem ao processo de certificação } \\
\text { pelo ENEM. }\end{array}$ \\
\hline MEC & $\begin{array}{l}\text { Portaria } \\
\text { normativa } n^{\circ} \\
10 \text { de } 23 \text { de } \\
\text { Maio de } 2012\end{array}$ & $\begin{array}{l}\text { Dispõe sobre } \\
\text { certificação de } \\
\text { conclusão do ensino } \\
\text { médio ou } \\
\text { declaração de } \\
\text { proficiência com } \\
\text { base no ENEM. }\end{array}$ & $\begin{array}{l}\text { A certificação de conclusão do ensino médio ou declaração de } \\
\text { proficiência com base no ENEM deverá atender aos requisitos } \\
\text { estabelecidos pelo Instituto Nacional de Estudos e Pesquisas } \\
\text { Educacionais-INEP, mediante adesão das Secretarias de Educação } \\
\text { dos Estados e dos Institutos Federais de Educação, Ciência e } \\
\text { Tecnologia. } \\
\text { A certificação pelo ENEM não pressupõe a frequência em escola } \\
\text { pública para efeito de concessão de benefícios de programas } \\
\text { federais. }\end{array}$ \\
\hline INEP & $\begin{array}{l}\mathbf{N}^{\circ} 42 \text {, de } 14 \text { de } \\
\text { Fevereiro de } \\
\quad 2012\end{array}$ & $\begin{array}{c}\text { Revoga a Portaria } \\
\mathrm{n}^{\circ} 110 \text {, de } 18 \text { de } \\
\text { maio de } 2011 \text { sobre } \\
\text { as edições do } \\
\text { ENEM. }\end{array}$ & $\begin{array}{l}\text { A Portaria revogada estabelecia que a partir de 2012, o ENEM } \\
\text { seria implementado, pelo menos, em duas edições por ano. A cada } \\
\text { divulgação de Edital do ENEM seria publicada Portaria que } \\
\text { estabeleceria as datas de realização da edição seguinte. }\end{array}$ \\
\hline MEC & $\begin{array}{c}\text { PORTARIA } \\
\text { NORMATIVA } \\
\text { No }^{\circ} \\
\text { 16, de } 27 \text { de } \\
\text { Julho de } 2011\end{array}$ & $\begin{array}{l}\text { Dispõe sobre } \\
\text { certificação no nível } \\
\text { de conclusão do } \\
\text { Ensino Médio ou } \\
\text { Declaração de } \\
\text { proficiência com } \\
\text { base no ENEM. }\end{array}$ & $\begin{array}{l}\text { Art.1 } 1^{\circ} \text { O interessado em obter certificação no nível de conclusão } \\
\text { do ensino médio ou declaração de proficiência com base no } \\
\text { Requisitos para certificação: } \\
\text { - possuir } 18 \text { completos até a data de realização da primeira prova } \\
\text { do ENEM; } \\
\text { - ter atingido o mínimo de } 400 \text { pontos em cada uma das áreas de } \\
\text { conhecimento do ENEM e no mínimo de } 500 \text { pontos na redação. } \\
\text { A certificação pelo ENEM destina-se, prioritariamente, às pessoas } \\
\text { que não concluíram o Ensino Médio em idade apropriada, } \\
\text { inclusive às pessoas privadas de liberdade e que estão fora do } \\
\text { sistema escolar regular. } \\
\text { Fica aprovado, na forma do anexo a esta Portaria, o modelo para } \\
\text { certificação de proficiência equivalente à conclusão do } \\
\text { Ensino Médio para os fins da certificação da educação de jovens e } \\
\text { adultos com base no ENEM. }\end{array}$ \\
\hline
\end{tabular}




\begin{tabular}{|c|c|c|c|}
\hline MEC & $\begin{array}{l}\mathrm{N}^{\circ} 183 \text {, de } 22 \\
\text { de Fevereiro } \\
\text { de } 2010\end{array}$ & $\begin{array}{c}\text { Fica aprovado na } \\
\text { forma do anexo a } \\
\text { esta Portaria, o } \\
\text { modelo para } \\
\text { certificação de } \\
\text { proficiência } \\
\text { equivalente à } \\
\text { conclusão do ensino } \\
\text { médio para os fins } \\
\text { da certificação da } \\
\text { educação de jovens } \\
\text { e adultos com base } \\
\text { no ENEM. } \\
\end{array}$ & $\begin{array}{l}\text { Modelo de anexo obedece ao disposto nos arts. } 36 \text { e } 38, \S 1^{\circ} \text {, II, } \\
\text { da Lei n }{ }^{\circ} \text { 9.394, de } 20 \text { de dezembro de } 1996 \text {, na Portaria } n^{\circ} 109 \text {, } \\
\text { de } 27 \text { de maio de } 2009 \text {, na Portaria Normativa n }{ }^{\circ} 4 \text {, de } 11 \text { de } \\
\text { fevereiro de 2010; e considerando a proficiência atingida pelo } \\
\text { interessado na prova da redação e em cada uma das áreas de } \\
\text { conhecimento abrangidas pelo ENEM; bem como o cumprimento } \\
\text { dos demais requisitos legais para a conclusão do ensino médio. }\end{array}$ \\
\hline MEC & $\begin{array}{c}\text { No }^{\circ} 807 \text {, de } 18 \\
\text { de Junho de } \\
2010\end{array}$ & $\begin{array}{l}\text { Institui o Exame } \\
\text { Nacional do Ensino } \\
\text { Médio - ENEM } \\
\text { como procedimento } \\
\text { de avaliação cujo } \\
\text { objetivo é aferir se o } \\
\text { participante do } \\
\text { Exame, ao final do } \\
\text { ensino médio, } \\
\text { demonstra domínio } \\
\text { dos princípios } \\
\text { científicos e } \\
\text { tecnológicos que } \\
\text { presidem a } \\
\text { produção moderna e } \\
\text { conhecimento das } \\
\text { formas } \\
\text { contemporâneas de } \\
\text { linguagem. }\end{array}$ & $\begin{array}{l}\text { - Institui e discorre a cerca: } \\
\text { - da certificação no nível de conclusão do ensino médio, pelo } \\
\text { sistema estadual e federal de ensino, de acordo com a legislação } \\
\text { vigente; } \\
\text { - da criação de referência nacional para o aperfeiçoamento dos } \\
\text { currículos do ensino médio; } \\
\text { - dos critérios de participação e acesso do examinando a } \\
\text { programas governamentais; } \\
\text { - da sua utilização como mecanismo único, alternativo ou } \\
\text { complementar aos exames de acesso à Educação Superior ou } \\
\text { processos de seleção nos diferentes setores do mundo do trabalho; } \\
\text { - do desenvolvimento de estudos e indicadores sobre a educação } \\
\text { brasileira. } \\
\text { - da responsabilidade do INEP em planejar e implementar o } \\
\text { exame, assim como promover a avaliação contínua do processo, } \\
\text { mediante articulação permanente com especialistas em avaliação } \\
\text { educacional, com as instituições de ensino superior e com as } \\
\text { secretarias estaduais de educação. } \\
\text { - da realização periódica do ENEM, com aplicação } \\
\text { descentralizada das provas, observadas as disposições contidas } \\
\text { nesta Portaria e em suas normas complementares. } \\
\text { - da participação voluntária, destinada aos concluintes ou egressos } \\
\text { do ensino médio e àqueles que não tenham concluído o Ensino } \\
\text { Médio, mas tenham no mínimo dezoito anos completos na data da } \\
\text { primeira prova de cada edição do Exame. } \\
\text { - da aplicação do ENEM que levará em consideração as questões } \\
\text { de acessibilidade e inclusão de pessoas com deficiência, assim } \\
\text { como as políticas de educação nas unidades prisionais. } \\
\text { - da taxa de inscrição, cujo valor será fixado anualmente pelo } \\
\text { INEP, destinada ao custeio dos serviços pertinentes à elaboração e } \\
\text { aplicação das provas, bem como ao processamento dos seus } \\
\text { resultados. } \\
\text { - da isenção do pagamento de inscrição os concluintes do Ensino } \\
\text { Médio, em qualquer modalidade, matriculados em instituições } \\
\text { públicas de ensino, ou aqueles que se declararem membros de } \\
\text { família de baixa renda, nos termos do Decreto no } 6.135 \text {, de } 26 \text { de } \\
\text { junho de } 2007 . \\
\text { - do banco de dados do INEP que emitirá relatórios com os } \\
\text { resultados do ENEM. }\end{array}$ \\
\hline MEC & $\begin{array}{l}\text { PORTARIA } \\
\text { NORMATIVA } \\
\mathbf{N}^{\circ} 4 \text {, de } 11 \text { de } \\
\text { Fevereiro de } \\
\quad 2010\end{array}$ & $\begin{array}{l}\text { Dispõe sobre a } \\
\text { certificação no nível } \\
\text { de conclusão do } \\
\text { ensino médio ou } \\
\text { declaração de } \\
\text { proficiência com } \\
\text { base no ENEM. }\end{array}$ & 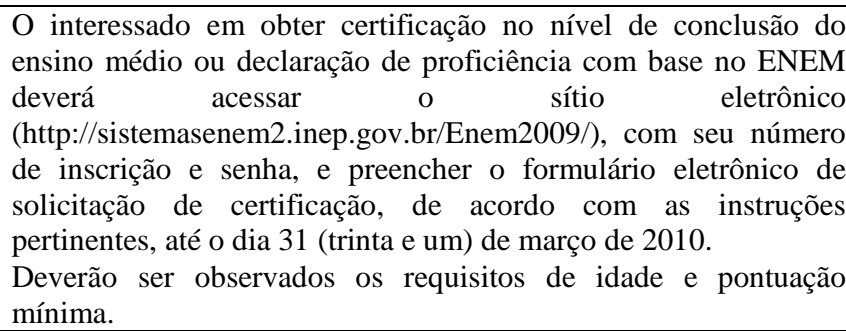 \\
\hline INEP & $\begin{array}{c}\text { No }^{0} 109 \text {, de } 27 \\
\text { de Maio de } \\
2009\end{array}$ & Institui o ENEM. & $\begin{array}{l}\text { Contém nos capítulos e sessões: } \\
\text { - Disposições preliminares, objetivos, inscrições, realização das } \\
\text { provas, das inscrições para concluintes e alunos da EJA, } \\
\text { pagamento de inscrição, das condições de realização das provas, } \\
\text { participantes com deficiência, da operacionalização. } \\
\text { - O Inep não utiliza os resultados do Enem para fins de seleção, }\end{array}$ \\
\hline
\end{tabular}




\begin{tabular}{|l|l|l|}
\hline & & $\begin{array}{l}\text { classificação ou premiação. Seus resultados são disponibilizados } \\
\text { para os estabelecimentos de ensino e as organizações do mundo } \\
\text { do trabalho interessadas em utilizá-los, desde que tenha } \\
\text { autorização, por escrito, do participante especificamente para } \\
\text { seleção ou classificação. } \\
\text { - O exame é de caráter voluntário, de abrangência nacional e em } \\
\text { decorrência da complexidade da sua logística inviabilizam a } \\
\text { analise de recursos e de vistas de provas. }\end{array}$ \\
\hline
\end{tabular}




\section{ANEXO 2 - QUESTIONÁRIO SOCIOECONOMICO (DICIONÁRIO DAS VARIÁVEIS ENEM 2015)}

\begin{tabular}{|c|c|c|c|c|c|}
\hline Q001 & $\begin{array}{l}\text { Até que série seu pai, ou o homem } \\
\text { responsável por você, estudou? }\end{array}$ & A & Nunca estudou. & 1 & \begin{tabular}{|l} 
Alfanu \\
mérica
\end{tabular} \\
\hline & & $B$ & \multicolumn{3}{|c|}{$\begin{array}{l}\text { Não completou a } 4^{\mathrm{a}} \text { série } / 5^{\circ} \text { ano do Ensino } \\
\text { Fundamental. }\end{array}$} \\
\hline & & C & \multicolumn{3}{|c|}{$\begin{array}{l}\text { Completou a } 4^{\mathrm{a}} \text { série } / 5^{\circ} \text { ano, mas não completou a } \\
8^{\mathrm{a}} \text { série } / 9^{\circ} \text { ano do Ensino Fundamental. }\end{array}$} \\
\hline & & D & \multicolumn{3}{|c|}{$\begin{array}{l}\text { Completou a a } \text { a série/9º ano do Ensino }^{\text {Fundamental, mas não completou o Ensino Médio. }} \\
\text { Funs }\end{array}$} \\
\hline & & $\mathrm{E}$ & \multicolumn{3}{|c|}{$\begin{array}{l}\text { Completou o Ensino Médio, mas não completou a } \\
\text { Faculdade. }\end{array}$} \\
\hline & & $F$ & \multicolumn{3}{|c|}{$\begin{array}{l}\text { Completou a Faculdade, mas não completou a } \\
\text { Pós-graduação. }\end{array}$} \\
\hline & & $G$ & Completou a Pós-graduação. & & \\
\hline & & $\mathrm{H}$ & Não sei. & & \\
\hline Q002 & $\begin{array}{l}\text { Até que série sua mãe, ou a mulher } \\
\text { responsável por você, estudou? }\end{array}$ & A & Nunca estudou. & 1 & $\begin{array}{l}\text { Alfanu } \\
\text { mérica }\end{array}$ \\
\hline & & $B$ & \multicolumn{3}{|c|}{$\begin{array}{l}\text { Não completou a } 4^{\mathrm{a}} \text { série } / 5^{\circ} \text { ano do Ensino } \\
\text { Fundamental. }\end{array}$} \\
\hline & & C & \multicolumn{3}{|c|}{$\begin{array}{l}\text { Completou a } 4^{\mathrm{a}} \text { série } / 5^{\circ} \text { ano, mas não completou a } \\
8^{\mathrm{a}} \text { série } / 9^{\circ} \text { ano do Ensino Fundamental. }\end{array}$} \\
\hline & & D & \multicolumn{3}{|c|}{$\begin{array}{l}\text { Completou a } 8^{\mathrm{a}} \text { série/ } / 9^{\circ} \text { ano do Ensino } \\
\text { Fundamental, mas não completou o Ensino Médio. }\end{array}$} \\
\hline & & $E$ & \multicolumn{3}{|c|}{$\begin{array}{l}\text { Completou o Ensino Médio, mas não completou a } \\
\text { Faculdade. }\end{array}$} \\
\hline & & $F$ & \multicolumn{3}{|c|}{$\begin{array}{l}\text { Completou a Faculdade, mas não completou a } \\
\text { Pós-graduação. }\end{array}$} \\
\hline & & $G$ & Completou a Pós-graduação. & & \\
\hline & & $\mathrm{H}$ & Não sei. & & \\
\hline Q003 & $\begin{array}{l}\text { A partir da apresentação de algumas } \\
\text { ocupações divididas em grupos ordenados, } \\
\text { indique o grupo que contempla a ocupação } \\
\text { mais próxima da ocupação do seu pai ou do } \\
\text { homem responsável por você. (Se ele não } \\
\text { estiver trabalhando, escolha uma ocupação } \\
\text { pensando no último trabalho dele). }\end{array}$ & A & \begin{tabular}{|l|} 
Grupo 1: Lavrador, agricultor \\
sem empregados, bóia fria, \\
criador de animais (gado, \\
porcos, galinhas, ovelhas, \\
cavalos etc.), apicultor, \\
pescador, lenhador, seringueiro, \\
extrativista.
\end{tabular} & 1 & $\begin{array}{l}\text { Alfanu } \\
\text { mérica }\end{array}$ \\
\hline & & $B$ & \multicolumn{3}{|c|}{$\begin{array}{l}\text { Grupo 2: Diarista, empregado doméstico, cuidador } \\
\text { de idosos, babá, cozinheiro (em casas } \\
\text { particulares), motorista particular, jardineiro, } \\
\text { faxineiro de empresas e prédios, vigilante, } \\
\text { porteiro, carteiro, office-boy, vendedor, caixa, } \\
\text { atendente de loja, auxiliar administrativo, } \\
\text { recepcionista, servente de pedreiro, repositor de } \\
\text { mercadoria. }\end{array}$} \\
\hline & & C & \multicolumn{3}{|c|}{$\begin{array}{l}\text { Grupo 3: Padeiro, cozinheiro industrial ou em } \\
\text { restaurantes, sapateiro, costureiro, joalheiro, } \\
\text { torneiro mecânico, operador de máquinas, } \\
\text { soldador, operário de fábrica, trabalhador da } \\
\text { mineração, pedreiro, pintor, eletricista, encanador, } \\
\text { motorista, caminhoneiro, taxista. }\end{array}$} \\
\hline & & D & \multicolumn{3}{|c|}{\begin{tabular}{|l|} 
Grupo 4: Professor (de ensino fundamental ou \\
médio, idioma, música, artes etc.), técnico (de \\
enfermagem, contabilidade, eletrônica etc.), \\
policial, militar de baixa patente (soldado, cabo, \\
sargento), corretor de imóveis, supervisor, gerente, \\
mestre de obras, pastor, microempresário \\
(proprietário de empresa com menos de 10 \\
empregados), pequeno comerciante, pequeno \\
proprietário de terras, trabalhador autônomo ou \\
por conta própria. \\
\end{tabular}} \\
\hline & & $\mathrm{E}$ & \multicolumn{3}{|c|}{$\begin{array}{l}\text { Grupo 5: Médico, engenheiro, dentista, psicólogo, } \\
\text { economista, advogado, juiz, promotor, defensor, } \\
\text { delegado, tenente, capitão, coronel, professor } \\
\text { universitário, diretor em empresas públicas e } \\
\text { privadas, político, proprietário de empresas com } \\
\text { mais de } 10 \text { empregados. }\end{array}$} \\
\hline & & $F$ & Não sei. & & \\
\hline Q004 & $\begin{array}{l}\text { A partir da apresentação de algumas } \\
\text { ocupações divididas em grupos ordenados, } \\
\text { indique o grupo que contempla a ocupação }\end{array}$ & A & $\begin{array}{l}\text { Grupo 1: Lavradora, agricultora } \\
\text { sem empregados, bóiia fria, } \\
\text { criadora de animais (gado, } \\
\text { porcos, galinhas, ovelhas, }\end{array}$ & 2 & $\begin{array}{c}\text { Numéri } \\
\text { ca }\end{array}$ \\
\hline
\end{tabular}




\begin{tabular}{|c|c|c|c|c|c|}
\hline & $\begin{array}{l}\text { mais próxima da ocupação da sua mãe ou da } \\
\text { mulher responsável por você. (Se ela não } \\
\text { estiver trabalhando, escolha uma ocupação } \\
\text { pensando no último trabalho dela). }\end{array}$ & & $\begin{array}{l}\text { cavalos etc.), apicultora, } \\
\text { pescadora, lenhadora, } \\
\text { seringueira, extrativista. }\end{array}$ & & \\
\hline & & $B$ & \multicolumn{3}{|c|}{\begin{tabular}{|l|} 
Grupo 2: Diarista, empregada doméstica, \\
cuidadora de idosos, babá, cozinheira (em casas \\
particulares), motorista particular, jardineira, \\
faxineira de empresas e prédios, vigilante, porteira, \\
carteira, office-boy, vendedora, caixa, atendente de \\
loja, auxiliar administrativa, recepcionista, \\
servente de pedreiro, repositora de mercadoria.
\end{tabular}} \\
\hline & & 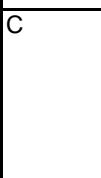 & \multicolumn{3}{|c|}{$\begin{array}{l}\text { Grupo 3: Padeira, cozinheira industrial ou em } \\
\text { restaurantes, sapateira, costureira, joalheira, } \\
\text { torneira meânica, operadora de máquinas, } \\
\text { soldadora, operária de fábrica, trabalhadora da } \\
\text { mineração, pedreira, pintora, eletricista, } \\
\text { encanadora, motorista, caminhoneira, taxista. }\end{array}$} \\
\hline & & D & \multicolumn{3}{|c|}{\begin{tabular}{|l|} 
Grupo 4: Professora (de ensino fundamental ou \\
médio, idioma, música, artes etc.), técnica (de \\
enfermagem, contabilidade, eletrônica etc.), \\
policial, militar de baixa patente (soldado, cabo, \\
sargento), corretora de imóveis, supervisora, \\
gerente, mestre de obras, pastora, microempresária \\
(proprietária de empresa com menos de 10 \\
empregados), pequena comerciante, pequena \\
proprietária de terras, trabalhadora autônoma ou \\
por conta própria.
\end{tabular}} \\
\hline & & E & \multirow{2}{*}{\multicolumn{3}{|c|}{$\begin{array}{l}\text { Grupo 5: Médica, engenheira, dentista, psicóloga, } \\
\text { economista, advogada, juíza, promotora, } \\
\text { defensora, delegada, tenente, capitã, coronel, } \\
\text { professora universitária, diretora em empresas } \\
\text { públicas e privadas, política, proprietária de } \\
\text { empresas com mais de } 10 \text { empregados. } \\
\end{array}$}} \\
\hline & & $\mathrm{F}$ & Não sei. & & \\
\hline \multirow[t]{20}{*}{ Q005 } & $\begin{array}{l}\text { Incluindo você, quantas pessoas moram } \\
\text { atualmente em sua residência? }\end{array}$ & & 1 & 2 & $\begin{array}{l}\text { Numéri } \\
\text { ca }\end{array}$ \\
\hline & & & 2 & & \\
\hline & & & 3 & & \\
\hline & & & 4 & & \\
\hline & & & 5 & & \\
\hline & & & 6 & & \\
\hline & & & 7 & & \\
\hline & & & 8 & & \\
\hline & & & 9 & & \\
\hline & & 10 & 10 & & \\
\hline & & 11 & 11 & & \\
\hline & & 12 & 12 & & \\
\hline & & 13 & 13 & & \\
\hline & & 14 & 14 & & \\
\hline & & 15 & 15 & & \\
\hline & & 16 & 16 & & \\
\hline & & 17 & 17 & & \\
\hline & & 18 & 18 & & \\
\hline & & 19 & 19 & & \\
\hline & & 20 & 20 & & \\
\hline \multirow[t]{10}{*}{ Q006 } & $\begin{array}{l}\text { Qual é a renda mensal de sua família? } \\
\text { (Some a sua renda com a dos seus } \\
\text { familiares.) }\end{array}$ & $A$ & Nenhuma renda. & 1 & $\begin{array}{l}\text { Alfanu } \\
\text { mérica }\end{array}$ \\
\hline & & $\mathrm{B}$ & Até $\mathrm{R} \$ 788,00$. & & \\
\hline & & C & De R\$ 788,01 até $\mathrm{R} \$ 1.182,00$. & & \\
\hline & & D & De R\$1.182,01 até $\mathrm{R} \$ 1.572,00$. & & \\
\hline & & $E$ & De $\mathrm{R} \$ 1.572,01$ até $\mathrm{R} \$ 1.970,00$. & & \\
\hline & & $\mathrm{F}$ & De R\$ 1.970,01 até R $\$ 2.364,00$. & & \\
\hline & & G & De $\mathrm{R} \$ 2.364,01$ até $\mathrm{R} \$ 3.152,00$. & & \\
\hline & & $\mathrm{H}$ & De $\mathrm{R} \$ 3.152,01$ até $\mathrm{R} \$ 3.940,00$. & & \\
\hline & & 1 & De $\mathrm{R} \$ 3.940,01$ até $\mathrm{R} \$ 4.728,00$. & & \\
\hline & & $\mathrm{J}$ & De R \$ 4.728,01 até $\mathrm{R} \$ 5.516,00$. & & \\
\hline
\end{tabular}




\begin{tabular}{|c|c|c|c|c|c|}
\hline & & $K$ & \multicolumn{2}{|c|}{ De R \$ 5.516,01 até $\mathrm{R} \$ 6.304,00}$. & \\
\hline & & $\mathrm{L}$ & \multicolumn{2}{|c|}{ De R\$ 6.304,01 até $\mathrm{R} \$ 7.092,00}$. & \\
\hline & & $\mathrm{M}$ & \multicolumn{2}{|c|}{ De R\$ 7.092,01 até $\mathrm{R} \$ 7.880,00}$. & \\
\hline & & $\mathrm{N}$ & \multicolumn{2}{|c|}{ De R\$ 7.880,01 até R\$ 9.456,00. } & \\
\hline & & O & \multicolumn{2}{|c|}{ De R\$ 9.456,01 até $\mathrm{R} \$ 11.820,00}$. & \\
\hline & & $\mathrm{P}$ & \multicolumn{2}{|c|}{ De R\$ $11.820,01$ até $\mathrm{R} \$ 15.760,00}$. & \\
\hline & & $\mathrm{Q}$ & Mais de $15.760,00$. & & \\
\hline \multirow[t]{4}{*}{ Q007 } & $\begin{array}{l}\text { Em sua residência trabalha empregado(a) } \\
\text { doméstico(a)? }\end{array}$ & A & Não. & 1 & $\begin{array}{c}\text { Alfanu } \\
\text { mérica }\end{array}$ \\
\hline & & $\mathrm{B}$ & \multicolumn{2}{|c|}{ Sim, um ou dois dias por semana. } & \\
\hline & & C & \multicolumn{2}{|c|}{ Sim, três ou quatro dias por semana. } & \\
\hline & & D & \multicolumn{3}{|c|}{ Sim, pelo menos cinco dias por semana. } \\
\hline \multirow[t]{5}{*}{ Q008 } & Na sua residência tem banheiro? & A & Não. & 1 & $\begin{array}{l}\text { Alfanu } \\
\text { mérica }\end{array}$ \\
\hline & & B & Sim, um. & & \\
\hline & & C & Sim, dois. & & \\
\hline & & D & Sim, três. & & \\
\hline & & $E$ & Sim, quatro ou mais. & & \\
\hline \multirow[t]{5}{*}{ Q009 } & Na sua residência tem quartos para dormir? & A & Não. & 1 & $\begin{array}{l}\text { Alfanu } \\
\text { mérica }\end{array}$ \\
\hline & & B & Sim, um. & & \\
\hline & & C & Sim, dois. & & \\
\hline & & D & Sim, três. & & \\
\hline & & E & Sim, quatro ou mais. & & \\
\hline \multirow[t]{5}{*}{ Q010 } & Na sua residência tem carro? & A & Não. & 1 & $\begin{array}{l}\text { Alfanu } \\
\text { mérica }\end{array}$ \\
\hline & & B & Sim, um. & & \\
\hline & & C & Sim, dois. & & \\
\hline & & D & Sim, três. & & \\
\hline & & E & Sim, quatro ou mais. & & \\
\hline \multirow[t]{5}{*}{ Q011 } & Na sua residência tem motocicleta? & A & Não. & 1 & $\begin{array}{l}\text { Alfanu } \\
\text { mérica }\end{array}$ \\
\hline & & B & Sim, uma. & & \\
\hline & & C & Sim, duas. & & \\
\hline & & D & Sim, três. & & \\
\hline & & $\mathrm{E}$ & Sim, quatro ou mais. & & \\
\hline \multirow[t]{5}{*}{ Q012 } & Na sua residência tem geladeira? & A & Não. & 1 & $\begin{array}{l}\text { Alfanu } \\
\text { mérica }\end{array}$ \\
\hline & & B & Sim, uma. & & \\
\hline & & C & Sim, duas. & & \\
\hline & & D & Sim, três. & & \\
\hline & & E & Sim, quatro ou mais. & & \\
\hline \multirow[t]{5}{*}{ Q013 } & $\begin{array}{l}\text { Na sua residência tem freezer (independente } \\
\text { ou segunda porta da geladeira)? }\end{array}$ & A & Não. & 1 & $\begin{array}{l}\text { Alfanu } \\
\text { mérica }\end{array}$ \\
\hline & & B & Sim, um. & & \\
\hline & & C & Sim, dois. & & \\
\hline & & D & Sim, três. & & \\
\hline & & E & Sim, quatro ou mais. & & \\
\hline \multirow[t]{5}{*}{ Q014 } & $\begin{array}{l}\text { Na sua residência tem máquina de lavar } \\
\text { roupa (o tanquinho NÃO deve ser } \\
\text { considerado)? }\end{array}$ & A & Não. & 1 & $\begin{array}{c}\text { Alfanu } \\
\text { mérica }\end{array}$ \\
\hline & & B & Sim, uma. & & \\
\hline & & C & Sim, duas. & & \\
\hline & & D & Sim, três. & & \\
\hline & & $\mathrm{E}$ & Sim, quatro ou mais. & & \\
\hline \multirow[t]{3}{*}{ Q015 } & $\begin{array}{l}\text { Na sua residência tem máquina de secar } \\
\text { roupa (independente ou em conjunto com a } \\
\text { máquina de lavar roupa)? }\end{array}$ & A & Não. & 1 & $\begin{array}{l}\text { Alfanu } \\
\text { mérica }\end{array}$ \\
\hline & & B & Sim, uma. & & \\
\hline & & C & Sim, duas. & & \\
\hline
\end{tabular}




\begin{tabular}{|c|c|c|c|c|c|}
\hline & & $\mathrm{D}$ & Sim, três. & & \\
\hline & & $E$ & Sim, quatro ou mais. & & \\
\hline \multirow[t]{5}{*}{ Q016 } & Na sua residência tem forno micro-ondas? & A & Não. & 1 & $\begin{array}{l}\text { Alfanu } \\
\text { mérica }\end{array}$ \\
\hline & & B & Sim, um. & & \\
\hline & & C & Sim, dois. & & \\
\hline & & D & Sim, três. & & \\
\hline & & $\mathrm{E}$ & Sim, quatro ou mais. & & \\
\hline \multirow[t]{5}{*}{ Q017 } & $\begin{array}{l}\text { Na sua residência tem máquina de lavar } \\
\text { louça? }\end{array}$ & A & Não. & 1 & $\begin{array}{l}\text { Alfanu } \\
\text { mérica }\end{array}$ \\
\hline & & B & Sim, uma. & & \\
\hline & & $\mathrm{C}$ & Sim, duas. & & \\
\hline & & D & Sim, três. & & \\
\hline & & E & Sim, quatro ou mais. & & \\
\hline \multirow[t]{2}{*}{ Q018 } & Na sua residência tem aspirador de pó? & A & Não. & 1 & $\begin{array}{l}\text { Alfanu } \\
\text { mérica }\end{array}$ \\
\hline & & B & Sim. & & \\
\hline \multirow[t]{5}{*}{ Q019 } & Na sua residência tem televisão em cores? & A & Não. & 1 & $\begin{array}{l}\text { Alfanu } \\
\text { mérica }\end{array}$ \\
\hline & & $B$ & Sim, uma. & & \\
\hline & & C & Sim, duas. & & \\
\hline & & $\mathrm{D}$ & Sim, três. & & \\
\hline & & E & Sim, quatro ou mais. & & \\
\hline \multirow[t]{2}{*}{ Q020 } & Na sua residência tem aparelho de DVD? & A & Não. & 1 & $\begin{array}{l}\text { Alfanu } \\
\text { mérica }\end{array}$ \\
\hline & & B & Sim. & . & \\
\hline \multirow[t]{2}{*}{ Q021 } & Na sua residência tem TV por assinatura? & A & Não. & 1 & $\begin{array}{l}\text { Alfanu } \\
\text { mérica }\end{array}$ \\
\hline & & B & Sim. & $x$ & \\
\hline \multirow[t]{5}{*}{ Q022 } & Na sua residência tem telefone celular? & A & Não. & 1 & $\begin{array}{l}\text { Alfanu } \\
\text { mérica }\end{array}$ \\
\hline & & B & Sim, um. & & \\
\hline & & C & Sim, dois. & & \\
\hline & & $\mathrm{D}$ & Sim, três. & & \\
\hline & & $E$ & Sim, quatro ou mais. & & \\
\hline \multirow[t]{2}{*}{ Q023 } & Na sua residência tem telefone fixo? & A & Não. & 1 & $\begin{array}{l}\text { Alfanu } \\
\text { mérica }\end{array}$ \\
\hline & & $B$ & Sim. & & \\
\hline \multirow[t]{5}{*}{ Q024 } & Na sua residência tem computador? & A & Não. & 1 & $\begin{array}{l}\text { Alfanu } \\
\text { mérica }\end{array}$ \\
\hline & & B & Sim, um. & & \\
\hline & & C & Sim, dois. & & \\
\hline & & D & Sim, três. & & \\
\hline & & $\mathrm{E}$ & Sim, quatro ou mais. & & \\
\hline \multirow[t]{2}{*}{ Q025 } & Na sua residência tem acesso à Internet? & A & Não. & 1 & $\begin{array}{l}\text { Alfanu } \\
\text { mérica }\end{array}$ \\
\hline & & B & Sim. & & \\
\hline \multirow[t]{3}{*}{ Q026 } & $\begin{array}{l}\text { Você exerce ou já exerceu atividade } \\
\text { remunerada? }\end{array}$ & A & Não, nunca trabalhei. & 1 & $\begin{array}{l}\text { Alfanu } \\
\text { mérica }\end{array}$ \\
\hline & & B & Sim, já trabalhei, mas nã & palha & \\
\hline & & C & Sim, estou trabalhando. & & \\
\hline \multirow[t]{10}{*}{ Q027 } & $\begin{array}{l}\text { Com que idade você começou a exercer uma } \\
\text { atividade remunerada? }\end{array}$ & A & Menos de 14 anos. & 1 & $\begin{array}{l}\text { Alfanu } \\
\text { mérica }\end{array}$ \\
\hline & & B & 15 anos. & & \\
\hline & & C & 16 anos. & & \\
\hline & & D & 17 anos. & & \\
\hline & & E & 18 anos. & & \\
\hline & & $\mathrm{F}$ & 19 anos. & & \\
\hline & & G & 20 anos. & & \\
\hline & & $\mathrm{H}$ & 21 anos. & & \\
\hline & & I & 22 anos. & & \\
\hline & & $\mathrm{J}$ & 23 anos. & & \\
\hline
\end{tabular}




\begin{tabular}{|c|c|c|c|c|c|}
\hline & & $\mathrm{K}$ & 24 anos. & & \\
\hline & & $\mathrm{L}$ & 25 anos ou mais. & & \\
\hline \multirow[t]{5}{*}{ Q028 } & $\begin{array}{l}\text { Quantas horas semanais você trabalha ou } \\
\text { trabalhava aproximadamente? (Considere a } \\
\text { atividade remunerada mais recente.) }\end{array}$ & $\mathrm{A}$ & Até 10 horas semanais. & 1 & \begin{tabular}{|l|} 
Alfanu \\
mérica
\end{tabular} \\
\hline & & B & De 11 a 20 horas semanais. & & \\
\hline & & C & De 21 a 30 horas semanais. & & \\
\hline & & D & De 31 a 40 horas semanais. & & \\
\hline & & E & Mais de 40 horas semanais. & & \\
\hline \multirow[t]{6}{*}{ Q029 } & $\begin{array}{l}\text { Indique a importância de cada um dos } \\
\text { motivos abaixo na sua decisão de trabalhar: } \\
\text { Ajudar meus pais nas despesas com a casa. }\end{array}$ & 0 & $\begin{array}{c}0 \text { indica o fator menos relevante } \\
\text { e } 5 \text { o fator mais relevante }\end{array}$ & 1 & $\begin{array}{c}\text { Numéri } \\
\text { ca }\end{array}$ \\
\hline & & 1 & & & \\
\hline & & 2 & & & \\
\hline & & 3 & & & \\
\hline & & 4 & & & \\
\hline & & 5 & & & \\
\hline \multirow[t]{6}{*}{ Q030 } & $\begin{array}{l}\text { Indique a importância de cada um dos } \\
\text { motivos abaixo na sua decisão de trabalhar: } \\
\text { Sustentar minha família (esposo/a, filhos/as } \\
\text { etc.). }\end{array}$ & 0 & $\begin{array}{c}0 \text { indica o fator menos relevante } \\
\text { e } 5 \text { o fator mais relevante }\end{array}$ & 1 & $\begin{array}{c}\text { Numéri } \\
\text { ca }\end{array}$ \\
\hline & & 1 & & & \\
\hline & & 2 & & & \\
\hline & & 3 & & & \\
\hline & & 4 & & & \\
\hline & & 5 & & & \\
\hline \multirow[t]{6}{*}{ Q031 } & $\begin{array}{l}\text { Indique a importância de cada um dos } \\
\text { motivos abaixo na sua decisão de trabalhar: } \\
\text { Ser independente/ganhar meu próprio } \\
\text { dinheiro. }\end{array}$ & 0 & $\begin{array}{c}0 \text { indica o fator menos relevante } \\
\text { e } 5 \text { o fator mais relevante }\end{array}$ & 1 & $\begin{array}{c}\text { Numéri } \\
\text { ca }\end{array}$ \\
\hline & & 1 & & & \\
\hline & & 2 & & & \\
\hline & & 3 & & & \\
\hline & & 4 & & & \\
\hline & & 5 & & & \\
\hline \multirow[t]{6}{*}{ Q032 } & $\begin{array}{l}\text { Indique a importância de cada um dos } \\
\text { motivos abaixo na sua decisão de trabalhar: } \\
\text { Adquirir experiência. }\end{array}$ & 0 & $\begin{array}{c}0 \text { indica o fator menos relevante } \\
\text { e } 5 \text { o fator mais relevante }\end{array}$ & 1 & $\begin{array}{c}\text { Numéri } \\
\text { ca }\end{array}$ \\
\hline & & 1 & & & \\
\hline & & 2 & & & \\
\hline & & 3 & & & \\
\hline & & 4 & & & \\
\hline & & 5 & & & \\
\hline \multirow[t]{6}{*}{ Q033 } & $\begin{array}{l}\text { Indique a importância de cada um dos } \\
\text { motivos abaixo na sua decisão de trabalhar: } \\
\text { Custear/pagar meus estudos. }\end{array}$ & 0 & $\begin{array}{c}0 \text { indica o fator menos relevante } \\
\text { e } 5 \text { o fator mais relevante }\end{array}$ & 1 & $\begin{array}{c}\text { Numéri } \\
\text { ca }\end{array}$ \\
\hline & & 1 & & & \\
\hline & & 2 & & & \\
\hline & & 3 & & & \\
\hline & & 4 & & & \\
\hline & & 5 & & & \\
\hline \multirow[t]{4}{*}{ Q034 } & $\begin{array}{l}\text { Indique os motivos que levaram você a } \\
\text { participar do ENEM: Testar meus } \\
\text { conhecimentos, para aumentar as minhas } \\
\text { chances de ingressar na Educação Superior. }\end{array}$ & 0 & $\begin{array}{c}0 \text { indica o fator menos relevante } \\
\text { e } 5 \text { o fator mais relevante }\end{array}$ & 1 & $\begin{array}{c}\text { Numéri } \\
\text { ca }\end{array}$ \\
\hline & & 1 & & & \\
\hline & & 2 & & & \\
\hline & & 3 & & & \\
\hline
\end{tabular}




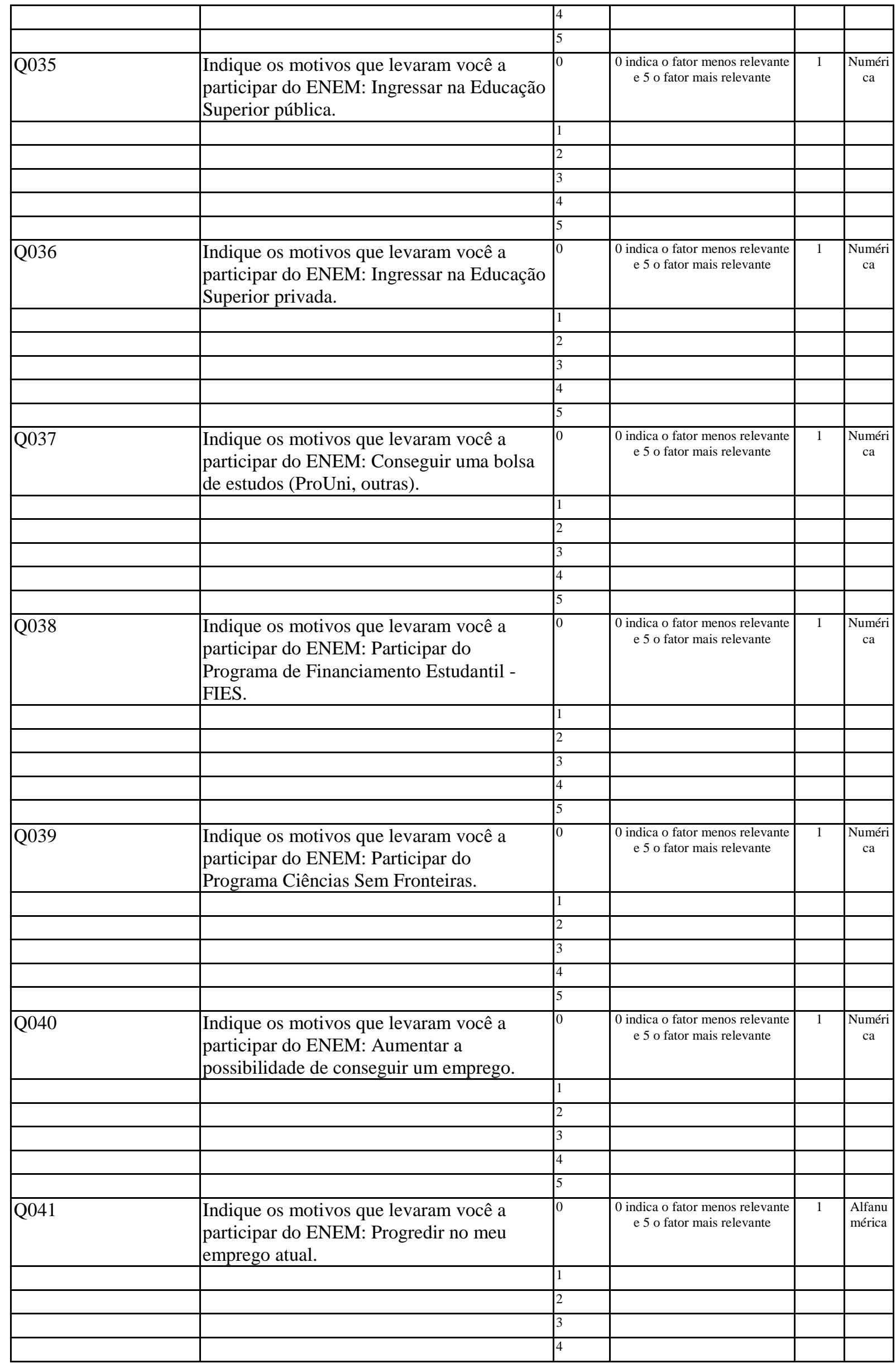




\begin{tabular}{|c|c|c|c|c|c|}
\hline & & 5 & & & \\
\hline \multirow[t]{8}{*}{ Q042 } & $\begin{array}{l}\text { Em que tipo de escola você frequentou o } \\
\text { Ensino Fundamental? }\end{array}$ & A & Somente em escola pública. & 1 & $\begin{array}{l}\text { Alfanu } \\
\text { mérica }\end{array}$ \\
\hline & & B & \multicolumn{2}{|l|}{ A maior parte em escola pública. } & \\
\hline & & C & Somente em escola particular. & & \\
\hline & & $\mathrm{D}$ & \multicolumn{2}{|l|}{ A maior parte em escola particular. } & \\
\hline & & E & Somente em escola indígena. & & \\
\hline & & $\mathrm{F}$ & \multicolumn{2}{|l|}{ A maior parte em escola indígena. } & \\
\hline & & G & \multicolumn{3}{|c|}{$\begin{array}{l}\text { Somente em escola situada em comunidade } \\
\text { quilombola. }\end{array}$} \\
\hline & & $\mathrm{H}$ & \multicolumn{3}{|c|}{$\begin{array}{l}\text { A maior parte em escola situada em comunidade } \\
\text { quilombola. }\end{array}$} \\
\hline \multirow[t]{4}{*}{ Q043 } & $\begin{array}{l}\text { Marque entre as opções abaixo aquela que } \\
\text { melhor descreve a modalidade de Ensino } \\
\text { Fundamental que você frequentou }\end{array}$ & $\mathrm{A}$ & \begin{tabular}{|l|} 
Cursei o Ensino Fundamental \\
somente na modalidade regular.
\end{tabular} & 1 & $\begin{array}{l}\text { Alfanu } \\
\text { mérica }\end{array}$ \\
\hline & & B & \multicolumn{3}{|c|}{$\begin{array}{l}\text { Cursei o Ensino Fundamental parte na modalidade } \\
\text { regular e parte na modalidade EJA (Educação de } \\
\text { Jovens e Adultos). }\end{array}$} \\
\hline & & C & \multicolumn{3}{|c|}{$\begin{array}{l}\text { Cursei o Ensino Fundamental somente na } \\
\text { modalidade EJA (Educação de Jovens e Adultos). }\end{array}$} \\
\hline & & D & Outras modalidades. & & \\
\hline \multirow[t]{3}{*}{ Q044 } & $\begin{array}{l}\text { Em que turno você frequentou o Ensino } \\
\text { Fundamental? }\end{array}$ & A & Somente no diurno. & 1 & $\begin{array}{l}\text { Alfanu } \\
\text { mérica }\end{array}$ \\
\hline & & B & \multicolumn{2}{|l|}{ Parte no diurno e parte no noturno. } & \\
\hline & & C & Somente no noturno. & & \\
\hline \multirow[t]{4}{*}{ Q045 } & $\begin{array}{l}\text { Durante o Ensino Fundamental, você } \\
\text { abandonou os estudos e/ou foi reprovado? }\end{array}$ & A & $\begin{array}{l}\text { Não abandonei, nem fui } \\
\text { reprovado. }\end{array}$ & 1 & $\begin{array}{l}\text { Alfanu } \\
\text { mérica }\end{array}$ \\
\hline & & B & \multicolumn{2}{|l|}{ Não abandonei, mas fui reprovado. } & \\
\hline & & C & \multicolumn{2}{|l|}{ Abandonei, mas não fui reprovado. } & \\
\hline & & D & Abandonei e fui reprovado. & & \\
\hline \multirow[t]{4}{*}{ Q046 } & $\begin{array}{l}\text { Você já concluiu ou está concluindo o } \\
\text { Ensino Médio? }\end{array}$ & A & Já concluí o Ensino Médio. & 1 & $\begin{array}{l}\text { Alfanu } \\
\text { mérica }\end{array}$ \\
\hline & & B & \multicolumn{3}{|c|}{$\begin{array}{l}\text { Estou cursando e concluirei o Ensino Médio em } \\
2015 .\end{array}$} \\
\hline & & C & \multirow{2}{*}{\multicolumn{3}{|c|}{\begin{tabular}{|l|} 
Estou cursando e concluirei o Ensino Médio após \\
2015. \\
Não concluí e não estou cursando o Ensino Médio.
\end{tabular}}} \\
\hline & & $\mathrm{D}$ & & & \\
\hline \multirow[t]{5}{*}{ Q047 } & $\begin{array}{l}\text { Em que tipo de escola você frequentou o } \\
\text { Ensino Médio? }\end{array}$ & A & Somente em escola pública. & 1 & $\begin{array}{l}\text { Alfanu } \\
\text { mérica }\end{array}$ \\
\hline & & B & \multicolumn{3}{|c|}{$\begin{array}{l}\text { Parte em escola pública e parte em escola privada } \\
\text { sem bolsa de estudo integral. }\end{array}$} \\
\hline & & C & \multicolumn{3}{|c|}{$\begin{array}{l}\begin{array}{l}\text { Parte em escola pública e parte em escola privada } \\
\text { com bolsa de estudo integral. }\end{array} \\
\end{array}$} \\
\hline & & $\mathrm{D}$ & \multicolumn{3}{|c|}{\begin{tabular}{|l|}
$\begin{array}{l}\text { Somente em escola privada sem bolsa de estudo } \\
\text { integral. }\end{array}$ \\
\end{tabular}} \\
\hline & & E & \multicolumn{3}{|c|}{$\begin{array}{l}\begin{array}{l}\text { Somente em escola privada com bolsa de estudo } \\
\text { integral. }\end{array} \\
\end{array}$} \\
\hline \multirow[t]{4}{*}{ Q048 } & $\begin{array}{l}\text { Marque entre as opções abaixo aquela que } \\
\text { melhor descreve a modalidade de Ensino } \\
\text { Médio que você frequentou }\end{array}$ & A & \begin{tabular}{|l|} 
Cursei o Ensino Médio somente \\
na modalidade regular.
\end{tabular} & 1 & $\begin{array}{l}\text { Alfanu } \\
\text { mérica }\end{array}$ \\
\hline & & B & \multicolumn{3}{|c|}{$\begin{array}{l}\text { Cursei o Ensino Médio parte na modalidade } \\
\text { regular e parte na modalidade EJA (Educação de } \\
\text { Jovens e Adultos). }\end{array}$} \\
\hline & & C & \multicolumn{3}{|c|}{$\begin{array}{l}\text { Cursei o Ensino Médio somente na modalidade } \\
\text { EJA (Educação de Jovens e Adultos). } \\
\end{array}$} \\
\hline & & $\mathrm{D}$ & Outras modalidades. & & \\
\hline \multirow[t]{3}{*}{ Q049 } & $\begin{array}{l}\text { Em que turno você frequentou o Ensino } \\
\text { Médio? }\end{array}$ & A & Somente no diurno. & 1 & $\begin{array}{l}\text { Alfanu } \\
\text { mérica }\end{array}$ \\
\hline & & B & Parte no diurno e parte no noturno & & \\
\hline & & C & Somente no noturno. & & \\
\hline Q050 & $\begin{array}{l}\text { Durante o Ensino Médio, você abandonou } \\
\text { os estudos por algum tempo e/ou foi } \\
\text { reprovado? }\end{array}$ & A & $\begin{array}{l}\text { Não abandonei, nem fui } \\
\text { reprovado. }\end{array}$ & 1 & $\begin{array}{l}\text { Alfanu } \\
\text { mérica }\end{array}$ \\
\hline & & B & Não abandonei, mas fui reprovado & & \\
\hline & & C & Abandonei, mas não fui reprovado & & \\
\hline & & D & Abandonei e fui reprovado. & & \\
\hline
\end{tabular}


1. Referente ao Enem 2015, trata-se de uma máscara e não o seu número de inscrição original no Enem. O mesmo NU_INSCRICAO para anos diferentes não identifica o mesmo participante no exame, não permite o acesso aos dados cadastrais como nome, endereço, RG etc, nem identifica o mesmo participante em microdados de pesquisas diferentes.

2. Foi considerado treineiro o inscrito que tinha menos de 18 anos no primeiro dia de realização do exame (24/10/2015) e que não havia concluído o ensino médio e não o concluiria em 2015

3. Número gerado como identificador da escola no Censo Escolar da Educação Básica.

4. Idade do inscrito em 31/12/2015. Idades inferiores a 10 anos e superiores a 100 anos estão com o campo vazio na base.

5. Segundo o Edital do Enem 2015, no ato da inscrição o participante deveria informar a deficiência ou a condição especial que motiva o atendimento diferenciado, além do atendimento específico de que necessita. 6. Segundo o Edital do Enem 2015, no ato da inscrição o participante poderia declarar-se travesti, transexual ou transgênero e solicitar o atendimento pelo Nome Social.

7. A opção de certificação só é apresentada para participantes concluintes com idade mínima de 18 anos, conforme Edital do Enem 2015.

8. As 45 primeiras posições deste campo são referentes as respectivas respostas. O asterisco (*) indica dupla marcação e o ponto (.) resposta em branco.

9. As 45 primeiras posições deste campo são referentes as respectivas respostas, das quais as 5 primeiras correspondem a parte de língua estrangeira. O asterisco $\left(^{*}\right)$ indica dupla marcação e o ponto (.) resposta em branco.

10. As 45 primeiras posições deste campo são referentes ao respectivo gabarito

11. As 50 primeiras posições deste campo são referentes ao respectivo gabarito, das quais, para as 10 primeiras, as 5 primeiras correspondem à prova de Língua Inglesa e as outras 5 à prova de Língua Espanhola. 